
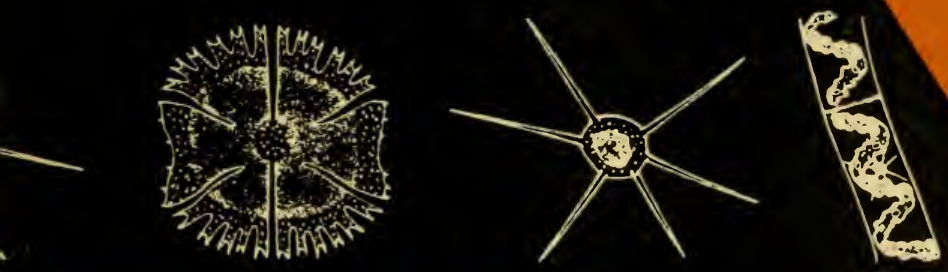

\title{
IOW TO KNOW
}

\section{THE}

\section{FRESH-VNATER ALgaE}

G. W. PRESCOTT

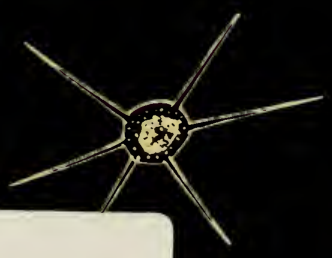

QK

567

P72

1954

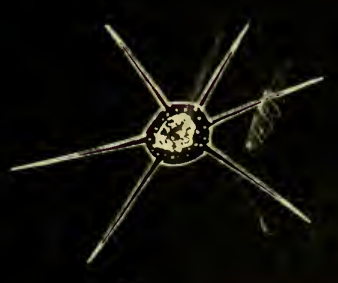

o

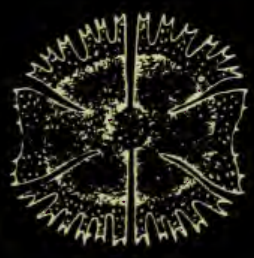

Pietured Key

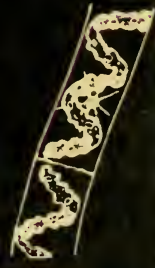

ka 


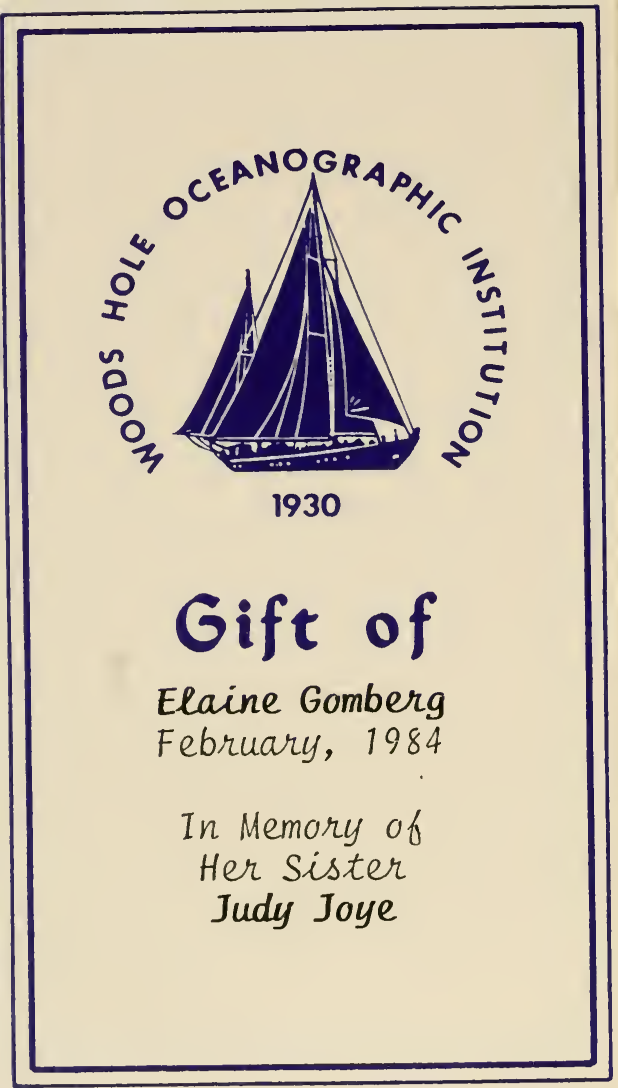




\section{Copyright 1954}

by

\section{H. E. Jaques}

Library of Congress Catalog Card Number: 55-3214

\section{THE PICTURED-KEY NATURE SERIES}

"How to Know the Insects," Jaques, 1947

"Living Things-How to Know Them," Jaques, 1946

"How to Know the Trees," Jaques, 1946

"Plant Families-How to Know Them," Jaques, 1948

"How to Know the Economic Plants," Jaques, 1948, 1958

"How to Know the Spring Flowers," Cuthbert, 1943, 1949

"How to Know the Mosses and Liverworts," Conard, 1944, 1956

"How to Know the Land Birds," Jaques, 1947

"How to Know the Fall Flowers," Cuthbert, 1948

"How to Know the Immature Insects," Chu, 1949

"How to Know the Protozoa," Jahn, 1949

"How to Know the Mammals," Booth, 1949

"How to Know the Beetles," Jaques, 1951

"How to Know the Spiders," Kaston, 1952

"How to Know the Grasses," Pohl, 1953

"How to Know the Fresh-Water Algae," Prescott, 1954

"How to Know the Western Trees," Baerg, 1955

"How to Know the Seaweeds," Dawson, 1956

"How to Know the Freshwater Fishes," Eddy, 1957

"How to Know the Weeds," Jaques, 1959

"How to Know the Water Birds," Jaques-Ollivier, 1960

"How to Know the Butterflies," Ehrlich, 1961

"How to Know the Eastern Land Snails," Burch, 1962

Other Subjects in Preparation 


\section{INTRODUCTION}

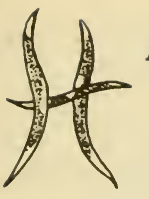

ARDLY any body of water or moist spot on the face of the earth is devoid of algae. They are almost as nearly ubiquitous as are the bacteria which are perhaps the most widely distributed organisms in the world. The variety of form and color exhibited by the algae is seemingly endless and Nature has shown no bounds in designing these ornate plants, many of which have bizarre shapes and specialized habits.

Because of the bright colors possessed by many algae and because their extensive growths which develop in ponds and streams, alyae frequently attract attention. The more conspicuous growths of freshwater algae are usually referred to erroneously by the stranger as "water moss," "moss," "frog-spittle," or are sometimes called "pond scums." This illustrated key is designed to give the student who is equipped with a microscope an opportunity to explore the world of freshwater algae and to give the correct scientific name (at least the genus name) to the more common forms. The student may find to his surprise that a clot of "moss" will include half a dozen or more distinct and recognizable plants, each with its own individual characteristics of form, method of reproduction, and life history. In some collections taken from acid bogs as many as 200 or more different species may be found.

It is hoped that this book will be a help in identifying the genera of freshwater algae and that it will serve toward the elimination of the indefinite and erroneous names under which they pass. To be sure, the naming of a plant or an animal is not necessarily an end unto itself-but identification and naming must serve as a basis for a study of structure, life history, ecological distribution and economic importance. Just as when one knows the name of a person and so can then learn more about him (or her), so the naming of algae can be the beginning of further investigation for the pure pleasure of getting acquainted with the world of aquatic life about us, or for scientific pursuits.

Having found the generic names of freshwater algae, the student may wish to identify the plants according to their specific names. For this he will want to turn to some of the works listed in the bibliography. An attempt has been made in illustrating the genera of algae to present the most common species that one is likely to meet, or to give illustrations of several species of a genus. In many cases, among the onecelled and colonial genera especially, there is considerable variation in form among the species contained in a genus. The student will 
need to keep this point in mind when matching a plant under consideration with the illustrations in the key. A plant in question may be a species somewhat or quite unlike the one shown.

The generic names used in the key are those of long-standing and the ones to be found in floras and handbooks the world over. In $\alpha$ few instances the names have been reduced to synonymy by specialists who have critically examined the old taxonomic literature for longforgotten synonymies. The advanced student is urged to look into the writings of specialists if he wishes to adopt the recent taxonomic terminologies.

East Lansing, Michigan

August 1, 1954

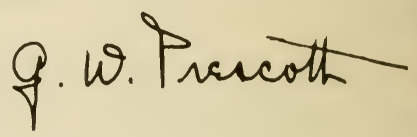

We first met Doctor Prescott when he was working on the Algae of lowa as a graduate student at our State University. We've had some pleasant correspondence through the years since then and now it is a pleasure to include the results of his years of study in our Pictured-Key Nature Series.

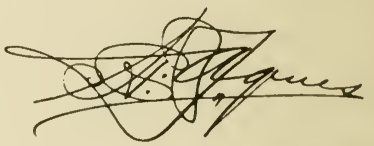

H. E. JAQUES

Editor

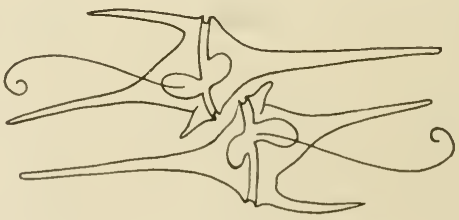




\section{CONTENTS}

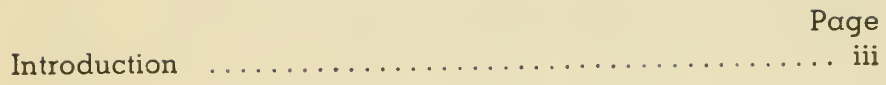

What Are Algae......................

The Phyla of Algae...................... 5

Synopsis of Algal Phyla....................... 10

How and Where to Collect Fresh-water Algae........ 12

Books and Papers Dealing with the Classification of

Fresh-water Algae...................... 18

Pictured-Keys to the More Common Fresh-water Algae.. 20

A Check List of the More Common Fresh-water Algae According to Families, Orders and Phyla.......... 189

Index and Pictured-Glossary ................... 199

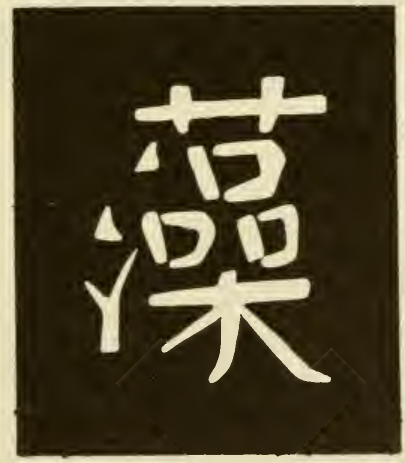

CHINESE IDIOGRAPH FOR THE
WORD ALGAE. 



\section{WHAT ARE ALGAE}

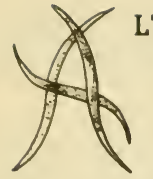

LTHOUGH most freshwater algae are microscopic, many kinds are greqarious and occur in such numbers as to form the well-known and conspicuous "pond scums," "water blooms," or "water mosses." A few genera are individually large enough to be seen easily without the aid of a microscope, e.g., the stone-worts (Characeae), or some of the freshwaier red algae such as Batrachospermum.

If it were possible for freshwater algae to grow as large cs some other plants (mosses and ferns for example) and to live upon land, they would be considered highly attractive indeed and would be much cultiva'ed as ornamentals. The symmetry of form and the patterns of external decorations which many of them possess are not excelled by the larger plants in beauty. The varied shapes of both marine and freshwater algae, coupled with their many colors and hues have made them the subject of observa-

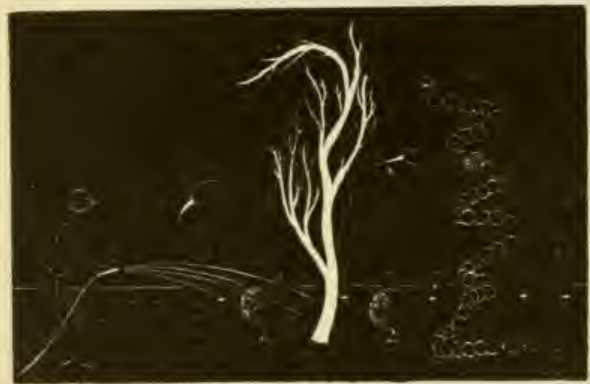
tion and wonderment for a long time, especially since the invention of the microscope. Indeed, the microscopic size of most of the freshwater algae make them all the more intriguing, and since the early days of the first microscopical club they have been used for pleasurable observation and speculation. It is not the aesthetic quality alone of freshwater algae, of course, which explains the amount of interest shown them. For small though they are. freshwater algae (like some of their microscopic kin in the oceans) have their own economic importance. Their relationship to aquatic biology problems of various kinds, their troublesome contamination of water supplies, and their use in general physiological research constitute just a few of the manv aspects which lead to a study of them. Purely scientific problems such as their role in organic evolution, the biology of their reproduction and life histories, and their ecology are common subjects of investigation. Although much is still to be learned from them, the solution, or at least clarification, of many problems in general biology and physiology have been obtained from studies of algae. At this time, for example, much attention is being given to algae in culture for the study of highly important and practical problems in photosynthesis and the products of algal metabolism. Some genera of unicellular algae are 
being used for the assay and detection of biologicals (vitamins and growth-promoting or growth-inhibiting substances) in tissue culture work. Some of the research on cancer involves studies in the physiology and reproduction of algal cells.

Whatever the interests in freshwater algae may be, the student who has access to a microscope can find many hours of fascination in a few drops of pond water.

The term "algae," derived from the Latin name for sea-wrack, has come to be applied to all relatively simple marine and freshwater vegetation. Actually, of course, many different kinds of organisms are included among the plants which lie outside or below the realm of mosses (Bryophytes), the ferns (Pteridophytes), and the seed-

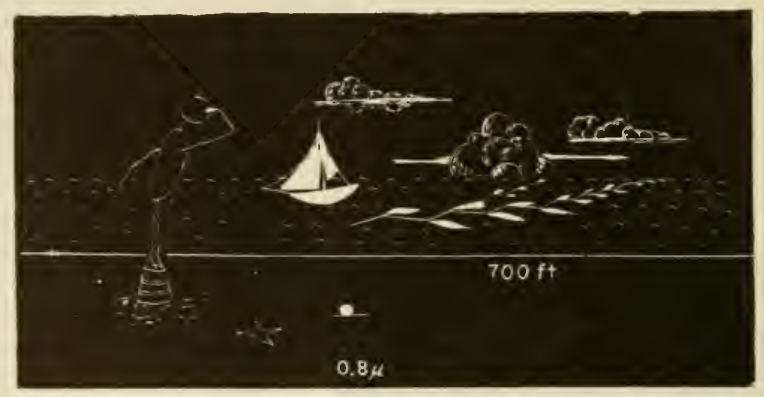

bearing plants (Spermatophyles). Included under "algae" are the smallest and most simple of chlorophyll-bearing organisms, the entire plant being but a single cell. Some of these may be less than 1 micron in diameter. At the other extreme, some of the brown algae (Phaeophyta) include the longest plants in the world. One of the kelps (Macrocystis) of the Pacific Ocean, for example, may reach 700 feet, and even greater lengths have been claimed.

The student soon learns that "algae" include several divisions or phyla of the plant kingdom, and that there are ircorporated even some groups of organisms, which, strictly speaking, belong neither to the plant nor to the animal kingdom (Euglenaceae. Dinoflagellatae, and many of the yellow-green algae such as Synura and Dinobryon). These are forms which usually are treated as chlorophyll-bearing protozoa in a reference book dealing with one-celled animals. Several of the swimming, protozoan-like forms have definitely plant-like, non-motile relatives, however, which more than justify their being given a place among the algae.

The reader who is not familiar with the classification of plants and animals, and with the terminology used for the different categories may wish to refer to the following definitions. 
SPECIES. A particular kind of plant or animal is called a species. For example, a certain rose, or a particular alga such as a "pond silk," or a particular bird is known as a species and is given an identifying or specific name. Because there is so much (although slight) variation between individuals which are in general very much alike, the limitations or precise definition of a species of plant or animal is often difficult to draw and is subject to different interpretations of specialists.

GENUS. All plants which obviously are roses, but not all the same kind, are grouped together and constitute what is known as a genus (plural, genera). Thus all different species of roses are placed in the genus Rosa, the Latin name for the genus. All species of "pond-silk" are placed in the genus Spircgyra. The genus name. Spirogyra, and a species name (a particular kind) together constitute the scientific name. For example, Spirogyra elongaia is the scientific name of a species which has long cells; Rosa cinnamoneo is the cinnamon rose. This method of naming each kind of plant and animal with a double name is known as the binomial system of nomenclature. The double name identifies not only a particular kind of individual but also indicates to what group (genus) it belongs.

FAMILY. The genus Rosa has much in common with the strawberry genus (Fragaria), and is much like the prune genus (Prunus). Similarly Spirogyra has much in common with another group of species which constitute the genus Mougeotia. Therefore, Rosa, Fragaria, Prunus, and other genera that have characteristics much in common are grouped to form what is called a family. In this case, the Rosaceae or Rose family. Spirogyra, Mougeotia, Zygnema and some other algal genera which have characteristics in common and which seem, therefore, to be related are grouped to form the family Zygnemataceae.

ORDER. In turn, families which are distinct from one another but which, nevertheless, have some few characters in common are grouped to form what is known as an order. Thus we have the Rosales, the Zygnematales, etc.

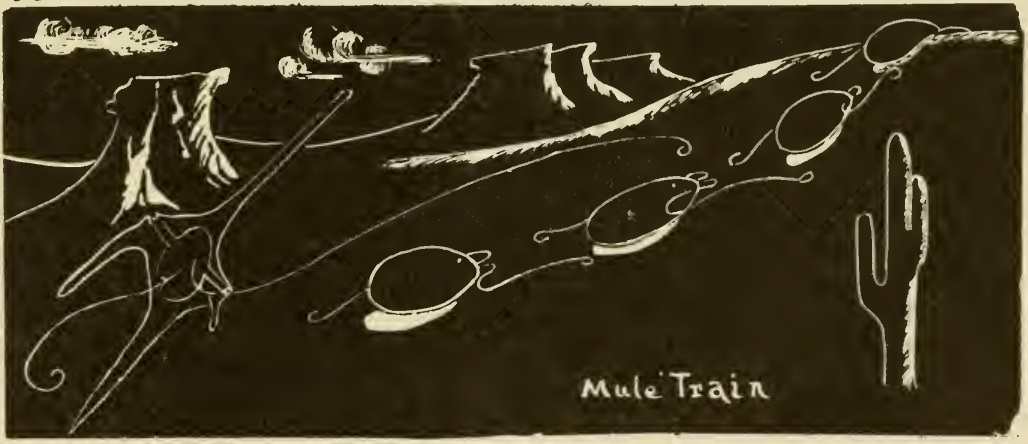

MOST aLgae aRE AQuATic 


\section{HOW TO KNOW THE FRESH-WATER ALGAE}

DIVISION or PHYLUM Several orders may be grouped to form a major category known as a Division or Phylum of the plant kingdom (or of the animal kingdom as the case may be). Thus several orders of the green algae constitute the division (phylum) Chlorophyta. In many instances it may be corvenient to subdivide the phylum into groups of orders called classes. Hence in the Chlorophyta there are recognized 2 classes, Chlorophyceae and Charophyceae. In the key which follows only the genus names are given, with illustrations of 1 or 2 common species. For this reason particular species in which the student may be interested in identifying will not necessarily look exactly like the ones illustrated. In so far as possible, the most distinctive features of the genus are shown in the illustrations.

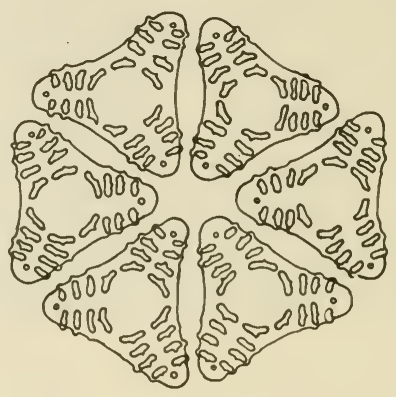




\section{THE PHYLA OF ALGAE}

HE organisms which constitute what are commonly known as freshwater algae are extremely diverse in form, color, habit, and in their habitats. Actually, there are as many as eight separate phyla or divisions of the plant kingdom included under the name "algae," (nine if Cryptophyceae of uncertain position are given the status of a division). Hence to undertake writing descriptively about freshwater algae, one is confronted with almost as great a task as if he were treating all ihe phyla of land plants, fungi, mosses, ferns and the seed plants, plus three additional groups all in one work. To be sure all the phyla of 'algae' do not include as many families and genera as do some of the higher plants, but the green algae alone include some ten or twelve thousand species, distributed among about 375 genera. The task of the writer in describing freshwater algae is not made easier by their relatively small (mostly microscopic) size. Hence it is necessary to employ special descriptive terms in order to differentiate these minute organisms, and to classify properly the classes and phyla to which they belong.

In such a treatment as is presented here, only the most common and best known genera can be given a place. The reader should have this in mind when using the key. He should avail himself of other less abridged or monographic works if satisfactory identification of a plant in which he is interested does not appear possible by the use of the following key.

The illustrated key is intended to assist the beginning student and the non-specialist (equipped with a microscope) in identifying the genera of freshwater algae which occur in the United States. Such a key cannot be made as easy to use as are many keys to larger organisms. But an attempt has been made to overcome some of the usual difficulties by keying out some genera at several different points, especially those which are so variable that selection of any one set of differentiating criteria for them is almost impossible. At least, a beginning student or one with little familiarity with the algae, must exercise patience until he has developed some degree of judgment and has become well-acquainted with the meaning of terms, and until he has discovered to what degree a plant may vary from the usual character employed in making an identification. Many times he will find it profitable, if not necessary, to "back-track" in using the key and follow down both dichotomies of choice before arriving at a satisfactory determniation. In making use of the illustrations it must be remembered that only one or two species of a genus are illustrated, and that the plant in which one may be inter- 
ested does not have to look exactly like the forms which are figured. This is true for many of the genera in the Chlorococcales of the Chlorophyta (Scenedesmus, Oocystis, Tetraedron, etc.) and of the desmids (Cosmarium, Euastrum, Micrasterias, e. g.) also in the Chlorophyta.

For a study of most freshwater algae a compound microscope is needed which has a $10 \mathrm{X}$ ocular, and a $10 \mathrm{X}$ and $40 \mathrm{X}$ objective. For the study of the larger forms such as the stoneworts (Characeae) a binocular dissecting microscope is highly desirable. Best illumination for the microscope is obtained from daylight because colors of the algal pigments appear more naturally. In lieu of good daylight (light from a northern window preferred), artificial light from a microscope lamp fitted with a daylight blue bulb is used, or a lamp which has a blue filter. Naturally, all optical parts of the microscope should be kept free of dust, moisture, and finger prints, using rice lens paper for cleaning. It is difficult enough to see algae clearly when optical conditions are perfect. An eye-piece micrometer is desirable.

In preparing mounts for the study of algae under the microscope, small amounts of material should be used, and spread out evenly in a thin layer. Dense clumps and opaque masses of algae in a microscope mount produce only disappointment and headaches.

One of the primary difficulties with which the inexperienced student is confronted when first using a general key to the algae is that of detecting and identifying colors, green, "blue-green," "yellow-green," etc., to which the key makes reference. Pigmentation in the different algal groups is a fundamental characteristic and one which is very helpful in making identification. But yellow-green algae may at times appear decidedly grass-green, and the brown-pigmented algae may have a distinct tinge of green, especially when artificial light is used for the microscope. Hence, other characters or a combination of characteristics excluding or in addition to color must be employed to make a choice in the key. Suggestions are given in appropriate places in the following key for making certain tests to help differentiate genera on the basis of color. Although it is a combination of characters which differentiates algae in the final analysis, the key can select these characters one by one only.

The three major phyla of algae (those which are the most common) are the green algae, the blue-green, and the yellow-green (yellow-brown). It is suggested that in order to facilitate the differentiation of a green, a blue-green, and a yellow-green alga, that (if possible) a known green alga (Spirogyra), a blue-green (Anabaena), and a diatom (yellow-brown) be mounted on a microscope slide so that their color and the details of cell structure might be compared. Then a series of illustrations depicting these groups of the algae should be examined so that the gross morphology and the details of cell structure will become associated with the respective pigmentations. 
The phyla of freshwater algae herein recognized are as follows:

1 Chlorophyta (Green Algae).

Plants unicellular, colonial, or filamentous; swimming, floating, or attached and stationary; cells containing plastids in which chlorophyll (grass-green) is predominant, and in which there is usually a shiny, starch-storing body, the pyrenoid; pigments are chlorophyll, xanthophyll, carotene; starch test with iodine positive (in almost every instance); nucleus definite (although often small and inconspicuous); cell wall usually relatively thick and definite, composed of cellulose and pectose; swimming cells or motile reproductive elements furnished with 2-4 flagella of equal length attached at the anterior end; sexual reproduction by iso-, aniso- and by heterogametes.

\section{Cyanophyta (Blue-Green Algae).}

Plants unicellular, colonial, or in simple or branched (sometimes falsely branched) filaments; without chloroplasts but with pigments in solution and coloring the entire protoplast; variously colored with a combination of chlorophyll, xanthophyll, carotene, phycocyanin, and phycoerythrin; cell wall thin, a membrane which usually has a gelatinous outer sheath; contents often with false (pseudo-) vacuoles which refract light and obscure the true color of the cells; definite nucleus lacking but occurring as a cluster of granules in the mid-region (central body) of the cell; motile cells and sexual reproduction wanting; asexual reproduction by cell division (fission) or rarely by spores (akinetes); food storage questionably glycogen, possibly floridean starch; iodine test for starch negative.

\section{Chrysophyta (Yellow-Green, or Yellow-Brown Algae).}

Plants unicellular or colonial, rarely filamentous; pigments contained in chromatophores in which yellow or brown often predominates, chlorophyll, carotene and xanthophyll also present (some chromatophores appearing pale green or yellow-green); food storage in the form of oil or leucosin, the latter often giving the cell a metallic lustre; starch test with iodine negative; wall relatively thick and definite, pectic in composition, often impregnated with silicon (especially in the diatoms), and sometimes built in 2 sections which overlap in the mid-region; motile cells and swimming reproductive cells furnished with 2 flagella of unequal length, or with but a single flagellum; rhizopodial (pseudopodial or amoeboid) extensions of the cell not uncommon in some families.

\section{Euglenophyta. (Euglenoids).}

Cells solitary, swimming by one (usually) or by 2 (rarely 3 ) flagella; a gullet present in the anterior end of the cell in many members, as is also a red pigment (eye) spot; chloroplasts few to many variously shaped green bodies (a few relatives colorless); a chlorophyll-like pigment predominating, but with carotene also present; nucleus large 
and centrally loca:ed; food reserve in the form of an insoluble starchlike substance, paramylum which is negative to the starch test with iodine, and fatty substances; cell membrane in the form of a pellicle, rigid or plastic, frequently striated; sexual reproduction unknown.

\section{Cryptophyta (Cryptophyceae of some authors).}

Cells solitary or colonial; mostly swimming by means of 2 , of:en laterally placed or sub-apical flagella; chromatophores large and brown, or rarely blue, often with pyrenoids; food reserve in the form of starch or oil; membrane firm but relatively thin; sexual reproduction unkown.

\section{Pyrrhophyta. (Dinoflagellates).}

Cells solitary or (rarely) filamentous; mostly swimming by means of 2 flagella, one commonly wound about the cell in a transverse furrow, and one extended posteriorly from the point of flagellar attachment in a longitudinal furrow; cells dorsiventrally flattened and differentiated, the longitudinal furrow extending along the ventral surface; cell wall, if present, firm and often composed of regularly arranged polygonal plates (as in the so-called armored or thecate Dinoflagellates); pigments chlorophyll, carotene, four xanthophylls, brown phycopyrrin, red peridinin (the latter sometimes predominating) contained within chromatophores; food reserve starch or a starch-like substance, and oili a pigment (eye) spot often present; sexual reproduction unknown.

\section{Rhodophyta. (Red Algae).}

Plants simple or branched filaments (unicellular in one questionable form); pigments contained within chromatophores, are chlorophyll, xanthophyll, carotene, phycocyanin and phycoerythrin, in the freshwater forms appearing blue-green, gray-green, or violet (not red); food reserve in the form of a special starch (floridean) which is negative to the iodine test for starch; walls relatively thick and often mucilaginous, sometimes furnished with pores through which protoplasmic extensions occur; sexual reproduction by heterogametes, but the male elements drifting and not swimming; thalli often of macroscopic size.

\section{Chloromonadophyta (Chloromonads).}

An obscure and little-understood group composed of but a few genera and species; cells swimming, flagella one or two, apically attached; chromatophores green, with chlorophyll (supposedly) predominating, but with an abundance of xanthophyll also present; food reserve in the form of oils or a fat; contractile vacuoles and a reservoir in the anterior end of the cell; cell contents with trichocysts radiately arranged just within the cell membrane (in the genus Gonyostomum), sexual reproduction unknown. 


\section{HOW TO KNOW THE FRESH-WATER ALGAE}

9 Phoeophyta. (Brown Algae).

A phylum mostly marine, including the brown sea weeds (kelps); essentially filamentous (some microscopic) but mostly robust and leathery: pigments include chlorophylls, carotene, xanthophyll, and fucoxanthin (predominating brown pigment); food reserve soluble carbohy. drates including alcohol (mannitol); reproduction asexual by kidney. shaped zoospores with 2 lateral flagella or sexual by iso- aniso- or heterogametes.

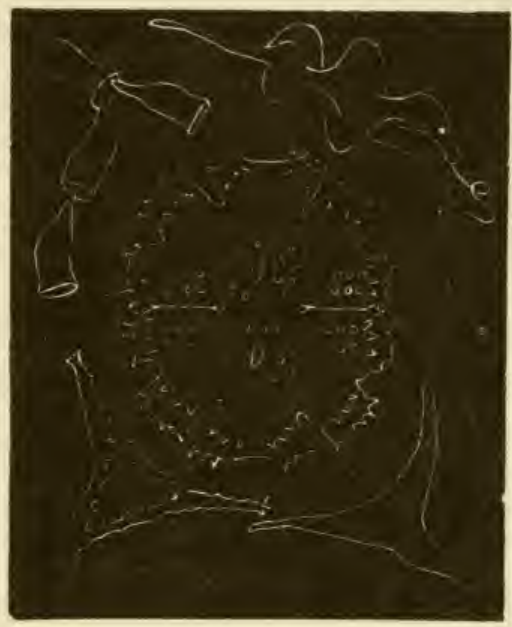




\section{SYNOPSIS OF THE ALGAL PHYLA}

INCE many species and whole divisions of algae are principally marine in habitat, the following general key or synopsis is given as an aid to a better understanding of the algal groups in fresh-water.

1 Cells without chloroplasts or chromatophores; pigments blue-green, olive-green, or purplish, distr:buted throughout the entire protoplast (although cells may be somewhat less colored in the central region); wall usually thin (often showing as a membrane only) and generally with a mucilaginous sheath (wide or narrow, watery or firm and definite); food reserve in the form of glycogen or a starch-like substance; iodine test for starch negative; no motile cells present. . Blue-Green Algae............. CYANOPHYTA

1 Cells with chloroplasts or with chromatophores, the pigments not distributed throughout the protoplast; cell wall clearly evident (with rare exceptions Pyramimonas, see Fig. 30, e.g.); stored food not in the form of glycogen; iodine test for starch positive or negative...2

2 Cells with grass-green chloroplasts (but see some species of Euglena, see Fig. 8, or the filamentous alga, Trentepohlia, see Fig. 171 which, although possessing chlorophyll, have the green color masked by an abundance of the red pigment, haematochrome)............

2 Cells with cholorplasts or chromatophores some other color, graygreen, brown, violet-green, or yellow-green, sometimes purplish...5

3 Free-swimming, unicellular; with numerous ovoid, star-shaped, or plate-like chloroplasts which are grass-green; food stored as clearly evident grains of insoluble paramylum (sticks, or plates); iodine test for starch negative; one or two (rarely three) coarse flagella attached at the apex in a gullet; eye-spot or red pigment spot usually evident.............Euglenoids.........EUGLENOPHYT $A$

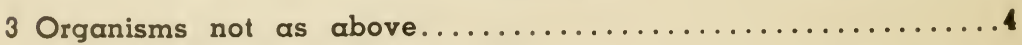

4 Unicellular, without an eye-spot; chloroplasts numerous discs usually radially directed at the periphery of the cell; motile by means of 2 flagella inserted in an apical reservoir; trichocyst organelles usually

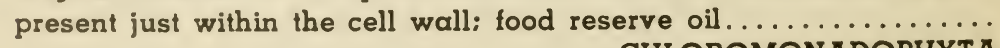

4 Unicellular, colonial, or filamentous; swimming or not swimming (although often free-floating); when swimming using 2 to 4 fine flagella attached at the apex of the cell but not in a colorless reser- 
voir; chloroplasts 1 to several, usually with a conspicuous pyrenoid (starch-storing granule); iodine test for starch positive...

Green Algae ....................................

5 Chromatophores light olive-brown to dark brown; nearly all marine, essent:ally filamentous, but occurring mostly as thalli of macroscopic size (brown sea weeds); stored food in the form of laminarin

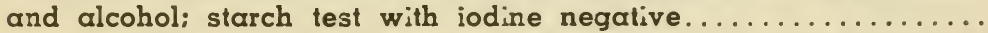
Brown Algae $\ldots \ldots \ldots \ldots \ldots \ldots \ldots \ldots \ldots \ldots \ldots \ldots \ldots$ PHAEOPHYTA

5 Plants marine or fresh-water, but not occurring as brown thalli of

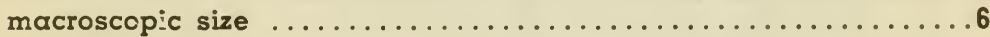

6 Chromatophores yellow-green to yellow- or golden-brown; food in the form of leucosin or 0.1 ; starch test with iodine negative; plants unicellular, colonial or filamentous: sometimes swimming with apically attached flagella; many forms (especially the diatoms, see Figs. 328-337) with the cell wall impregnated with silicon..... Yellow-green Algae $\ldots \ldots \ldots \ldots \ldots \ldots \ldots \ldots$ CHRYSOPHYTA

6 Chromatophores not yellow-green or pale green, but dark golden brown, gray-green, violet-green; food in the form of oil or starchlike carbohydrates; iodire test for starch mostly negative........7

7 Unicellular, with dark, golden-brown chromatophores; swimming by means of 2 laterally attached flagella; a conspicuous eye-spot usually present; many forms with the cell wall composed of polygonal plates..$\ldots \ldots \ldots$. Dinoflagellates.......... PYRRHOPHYTA

7 Organisms unicellular or filamentous, not swimming by means of laterally attached flagella; chromatophores brown, green, bluish, violet-green or gray-green...........................

8 Chromatophores violet or gray-green, sometimes bluish-green in fresh water, red in marine forms; occurring as filamentous thalli of both macroscopic and microscopic size; food stored in the form of starch-like carbohydrates; starch test with iodine negative....... Red Algare ................................

8 Chromatophores one or two golden-brown (rarely blue) bodies; organisms unicellular; swimming by means of sub-apically attached flagella; food reserve in the form of starch-like carbohydrates; iodine test positive in some.................... CRYPTOPHYT $\bar{A}$

(This class of the algae has several characteristics in common with Dinoflagellates and in some systems of classification is included under the Pyrrhophyta.) 


\section{HOW AND WHERE TO COLLECT FRESH-WATER ALGAE}

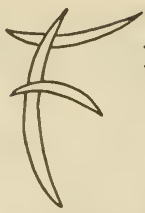

ILAMENTOUS algae can be collected from mass growths by hand, of course, and representative tufts placed in vials or collecting jars. Less conspicuous forms may be found as fuzzy films on submerged grasses, old rush culms, and sticks. Using the fingers these growths can be lifted away or pulled from their attachment, or short sections of stems of aquatic plants and grass leaves can be placed in vials and the algae removed with scraping tools in the laboratory. A dropping pipette and a pair of tweezers are useful for collecting minute forms.

Using the back of the thumb nail, or a dull-edged knife will serve, greenish coatings on rocks and submerged wood can be scraped away. Such an instrument is useful for removing samples of green or brown felt-like or mucilaginous growths from wet stones about waterfalls, from dripping cliffs and rocky outcrops.

Submerged glass, shells, and bits of crockery in the water furnish substrates for many algae which occur as inconspicuous green discs or tufts. Old, rotting wood may be perforated with algae which lie so far below the surface that they are scarcely visible, but wood that appears at all greenish from the exterior should be examined.

Feel under the rim of dams or along the edges of stones in flowing water. Many blue-green and also some of the more rare freshwater red algae occur in such habitats.

On and in damp soil are to be found numerous species of Cyanophyta and diatoms. Sometimes algae occur in pure strands' and sheets or films of a single species may be lifted or scraped from soil, wet boards, and the face of moist cliffs.

On beaches near the water line, but back far enough where the sand lies unmolested most of the time, the upper dry layer of sand may be removed to disclose a densely green stratum of algae. The green sand can be scraped into a container and rinsed, and then when the water is poured off in the laboratory an interesting mixture of algae will be found, together with a variety of microscopic animals (protozoa, rotifers, copepods, etc.). This biotic cosmos is known as psammon and includes many organisms that normally occur in sandy beaches although not in the open water of a nearby lake or stream.

In Nitella (one of the large green algae), in Lemna trisulca (one of the duckweeds), in Ricciocarpus natans (a floating liverwort) occur various green and blue-green endophytic algae. Small portions of these 
aquatic plants, and others as well, may be allowed to age and to become discolored in dishes of water in the laboratory. The endophytes (and some epiphytes too) will then appear more clearly and can be dissected away for study.

In humid climates trunks of trees and surfaces of leaves may have epiphytic or endophytic (semi-parasitic) algae such as Trentepohlia

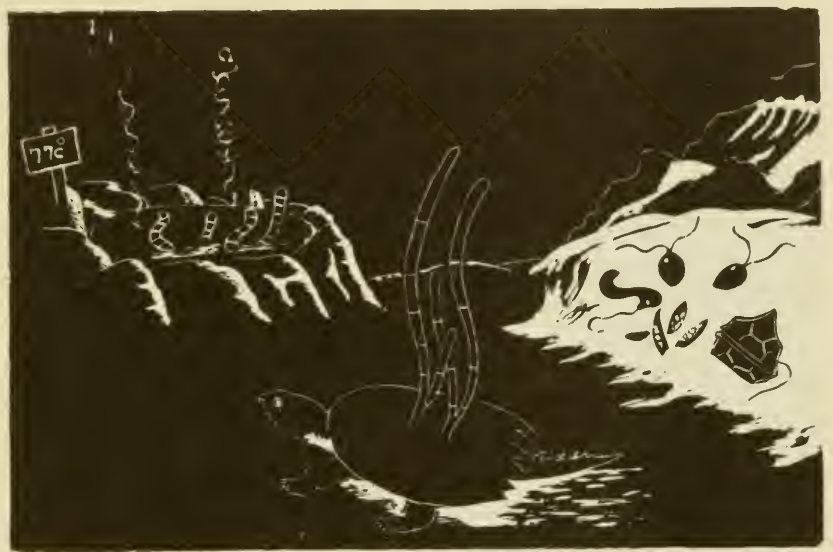

The habitats of freshwater algoe are very diverse, some living in hot springs where the water is nearly at boiling temperature; others in snow banks in high mountains; whereas one alga normally occurs on the back of the snapping turtle.

and Cephaleuros. Arisaema (Indian turnip) leaves invariably contain the parasitic alga, Phyllosiphon, which causes yellow or red spots in the host tissues.

One interesting habitat is the back of snapping turtles where the coarse, wiry filamentous alga, Basicladia is invariably found. Other algae may be associated with Basicladia on the 'mossy' backs of turtles, whereas alligators are sometimes veritable algal gardens and offer a variety of interesting forms for the less timid collector. In the rain-forests of the tropics, Central America, e.g., the three-toed sloth harbors among its hair scales a minute red alga, Cyanoderma bradypodis, and a filamentous green alga, Trichophilus welcheri.

In alpine and subalpine regions where there are banks of permanent snow, red streaks will be found at the margins of the snow fields. The streaks are produced by the unicellular green alga, Chlamydomonas nivalis which contains a red pigment (haematochrome) which is developed in the cells when they are exposed to intense 
light. A small quantity of red or 'bloody' snow when allowed to melt in a jar may yield a surprising quantity of this and other genera such as Scotiella, Ankistrodesmus, and certain Dinoflagellates.

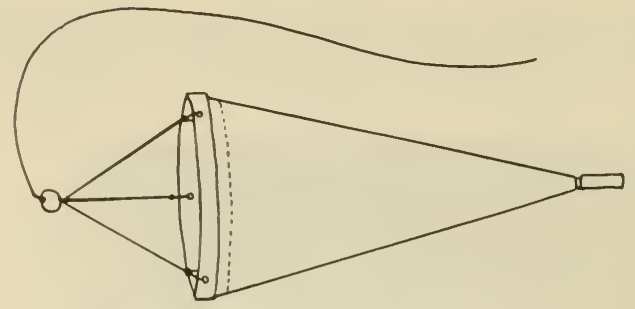

THE PLANKTON NET

Specimens collected from the open water (planktonic algae) are best collected with a cone-shaped, silk, bolting cloth net (No. 20). Plankton nets are obtainable from biological supply houses, or may be made up by securing a yard of the silk from an importer or from a flour mill.

(The Limnological and Oceanographic Society of America publishes a list of commercial houses and firms where various kinds of collecting equipment may be obtained.) A light-weight, brass (preferred) or thin galvanized iron ring (stout wire), or band may be used for the mouth of the net. A convenient size is a ring about 6 or 8 inches in diameter. Using a pattern, (see Welch, P. S. 1948. Limnological Methods, Blakiston Co., p. 234-235) cut the silk so that when attached to the ring a cone about 14 inches long is formed. The silk should not be attached directly to the ring, but sewed first to a band of stout muslin which then may be sewed over the ring or metal band. If a flat band is used for the mouth of the net the edges should be filed smooth and rounded to eliminate as much cutting and fraying of the muslin cloth as possible. The net may be used as a closed cone, in which case after a sample has been collected, the net must be turned inside out and the material washed off in a dish or jar. More conveniently, the tip of the cone may be cut off at a point (about $1 / 2$ in. or less from the end) which will permit the insertion of a small homeopathic vial (4 to 6 dram capacity) which can be tied about its neck into the apex of the net. Thus the sample will become concentrated in the vial and when the net is reversed the material can be poured out into a collecting bottle, and the net rinsed before another sample is taken. Better still, a small metal (lightweight) band, threaded to receive a screw-cap vial neck can be sewed into the tip of the net. Then the vial can be simply unscrewed and a fresh one inserted after the net has been rinsed.

The net should have 3 leaders of equal length attached to the ring at regularly spaced points. The leaders should be tied to a small ring to which the tow cord is also attached. Use a heavy line 


\section{HOW TO KNOW THE FRESH-WATER ALGAE}

such as a stout chalk line for the pull cord and the leaders. Braided copper wire is sometimes used for the leaders but these often become so worn at the points of attachment that they snap.

Microscopic forms of algae may be obtained in great numbers from the squeezing of Sphagnum (and other mosses) especially when the plants feel slippery or slimy. Small pools and seeps in Sphagnum beds abound in many species of algae, especially desmids. The moss or overhanging dead grass and stems of rushes can be squeezed di-

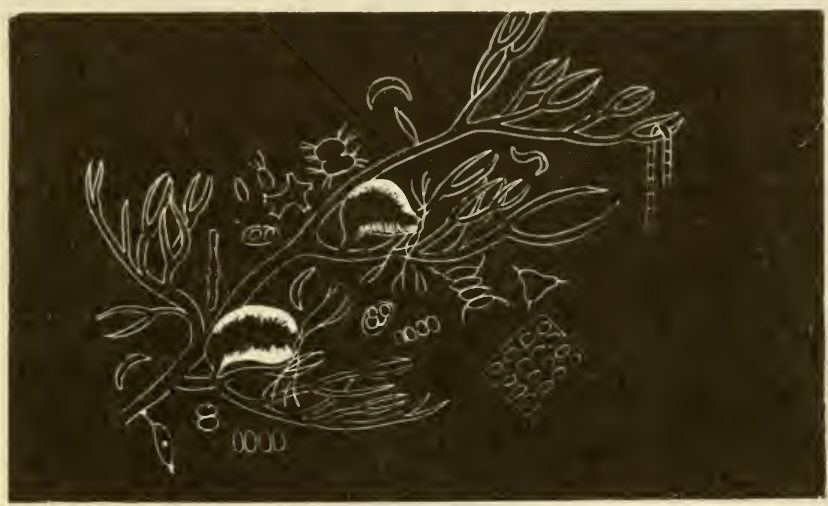

Utricularia, an under-water animal-trapping plant, is a veritable Christmas tree loaded with miscellaneous algae which are caught among the leaves and held in the mucilage that envelopes the plant.

rectly into a vial, or if a gross, mass collection is desired, the moss can be squeezed into the plankton net so that a concentrated puree of algae is obtained. Utricularia (bladderwort), especially when it occurs in soft water or acid lakes, is a veritable net itself and handfuls of this plant can be squeezed into a plankton net with very fruitful results.

Specimens collected from the field should be put in receptacles with just enough water to cover them, leaving ample space for air, especially if the sample is to be stoppered for some time before arriving at the laboratory. Clots of larger, filamentous algae may have the excess water gently squeezed from them, rolled in wet, and then in dry paper (newspaper highly satisfactory) and so may be kept in good condition for 24 hours or more.

Immediately upon returning from the field, vials or packets of material should be opened and poured into wide, shallow dishes so that they may be well aerated. If the collection is not too crowded in a dish of water the plants may be kept alive and in good condi- 
tion almost indefinitely, especially if the dishes are stored in a cool place with reduced illumination such as in a north facing window. Some kinds of algae will remain in satisfactory condition for study (even though additional growth may not occur) when stored in a refrigerator kept at ordinary temperatures used in food storage.

Some collectors prefer to spread algae on cards or stiff paper to dry, and then made into herbarium specimens. In working with such specimens later, a few drops of water placed on the dried plants will soak up the material well enough that it can be lifted away for mounting on a slide. Specimens so treated, however, are not satisfactory for study unless one has had a long experience in examining algae and is familiar with their appearance in the undried condition.

If it is desirable to keep a record of the location from which separate field collections are made, it is obviously necessary to give samples a code number or label at the time they are taken. One satisfactory way of doing this is to carry $3 \times 5$ inch cards, all but cut through into narrow sirips that will fit into the collecting vial. $\mathbb{A}$ number can then be written on a slip which is torn off from the card and inserted. Information bearing the same code number can be written into a field notebook for future reference. In the laboratory a permanent number can be assigned to the vial and written on the cork if the mater.al is to be saved for subsequent study.

\section{PRESERVING}

If samples are to be preserved an amount of 6-3-1 preservative equal to the volume of the specimen (and its water medium) may be added to the vial. This preservative is composed of six parts water, 3 parts $95 \%$ alcohol, and one part commercial formalin. If $5 \mathrm{cc}$ of glycerin are added to each $100 \mathrm{cc}$ of the preservative, a medium is produced which protects the specimen against total loss should the preservative evaporate. Cork-stoppered vials, as a rule, are much more serviceable than screw-cap vials which permit a greater amount of evaporation of the liquid because the tops loosen upon standing for a time.

Formalin-acetic acid-alcohol ( $F A \AA$ ) makes an excellent preservative and is especially suitable if material is later to be prepared for staining. To $50 \mathrm{cc}$ of $95 \%$ alcohol add $5 \mathrm{cc}$ of glacial acetic acid, 10 cc of commercial formalin, and $35 \mathrm{cc}$ of water. Proprionic acid may be substituted for the glacial acetic.

For general and incidental preserving, ordinary $3 \%$ formalin may be used if the above ingredients are not available. (3 cc of commercial formalin in $37 \mathrm{cc}$ of water.)

If semipermanent microscopic mounts are desired, specimens may be placed on a slide, evenly spread out, in a large drop of $5 \%$ glycerin. 
The slide should be set away under a dust-proof cover. Once or twice a day for two or three days other drops of the glycerin solution are added until, through evaporation of the water, approximately $100 \%$ glycerin is obtained about the specimen. To this a small drop of melted glycerin jelly is added and the cover slip put in place. Care should be used to add just enough jelly to fill out the area under the cover slip so as not to allow leakage from beneath it. The cover may then be ringed with a sealing material such as balsam, colorless fingernail polish, Bismark Black, or Gold Size. (See catalogues of biological supply houses which list other kinds of mounting and sealing materials.)

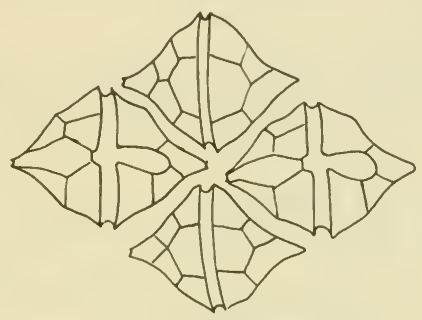




\section{A Selected List of Books and Major Papers Dealing With the Classification of Fresh-water Algae}

Atkinson, G. F. 1890. Monograph of the Lemaneaceae of the United States. Ann. Bot., 4; 177-229. Pls. 7-9.

Boyer, C. S. 1916. Diatomaceae of Philadelphia and Vicinity. Philadelphia.

Prunnthaler, J. 1915. Protococcales. In: A. Pascher. Die Susswasserflora Deutschlands, Osterreichs und der Schweiz. Heft 5. Chlorophyceae 2: 52-205. Jena.

Chapman, V. J. 1941. An introduction to the study of algae. Macmillan Co., New York.

Collins, F. S. (1909) 1928. The green algae of North America. Tufts College Studies, Sci. Ser. 2(1909); 79-480. Pls. 1-18. Reprinted with supplements 1 and 2 by G. E. Stechert Co., New York, 1928.

Eddy, Samuel. 1930. The fresh-water armored or thecate Dinoflagellates. Trans. Amer. Microsc. Soc., 49: 277-321. Pls. 28-35.

Elmore, C. J. 1921. The diatoms (Bacillarioideae) of Nebraska. Univ. Nebr. Stud., 21(1/4): 1-214. 23 Pls.

Fritsch, F. E. 1935, 1945. The structure and reproduction of the algae. I, II. Cambridge University Press.

Geitler, L. 1930-1931. Cyanophyceae. In: L. Rabenhorst, Kryptogamen-Flora von Deutschland, Osterreich und der Schweiz. 14 Lf. 1(1930): 1-288; Lf. 2(1931): 289-464. Figs. 1-131. Leipzig.

Gojdics, Mary. 1953. The Genus Euglena. Univ. Wisconsin Press.

Heering, W. 1914. Ulotrichlaes, Microsporales, Oedogoniales. In: A. Pascher, Die Susswasserflora Deutschlands, Osterreich und der Schweiz. Heft. 6, Chlorophyceae 3: 1-250. Figs. 1-384. Jena.

Irenee-Marie, Fr. 1939. Flore desmidiale de la region du Montreal. 547 pp. 69 Pls. La Prairie, Canada.

Jaques, H .E. 1948. Plant families - how to know them. Wm. C. Brown Co., Dubuque, Iowa.

Krieger, W. 1933-1939. Die Desmidiaceen. In: L. Rabenhorst, Kryptogamen-Flora von Deutschland, Osterreich, und der Schwiez. 13 Abt. 1: 1-712. Pls. 1-96; Abt. 1, Teil 2: 1-117. Pls. 97-142. Leipzig.

Lemmermann, E. 1913. Euglenineae. Flagellatae 2. In: A. Pascher, Die Susswasserflora Deutschlands, Osterreich, und der Schweiz. Heft 2: 115-174. Figs. 181-377. Jena. 
Pascher, A. 1927. Volvocales-Phytomonadinae. In: Die Susswasserflora Deutschlands, Osterreich und der Schweiz. Heft 4: 1-506. Figs. 1-451. Jena.

Pascher, A. 1937-1939. Heterokonten. In: L. Rabenhorst, KryptogamenFlora von Deutschland, Osterreich und der Schweiz. XI: 1-1097. Figs. 1-912.

Prescott, G. W. 1927. The motile algae of Iowa. Univ. Iowa Stud. Nat. Hist., 12: 1-4C. Pls. 1-10.

Prescott, G. W. 1931. Iowa algae. Iibd., 13: 1-235. Pls. 1-39.

Prescott, G. W. 1951. Algae of the Western Great Lakes Area. 933 pp. $136 \mathrm{Pls}$. Cranbrook Press.

Schiller, J. 1933-1937. Dinoflagellatae. In: L. Rabenhorst, Kryptogamen-Flora von Deutschland, Osterreich und der Schweiz. X(1933), Teil 1: 1-617; Teil 2, Lf. 1(1935): 1-160; Lf. 2(1935): 161-320; Lf. 3(1937): 321-480; Lf. 4(1937): 481-590. Leipzig.

Smith, G. M. 1920, 1924. Phytoplankton of the inland lakes of Wiscorsin. I, II. Wis. Geol. Nat. Hist. Surv. Bull. 57. Madison.

Smith, G. M. 1950. Freshwater algae of the United States. 2nd Ed. 719 pp. 559 Figs. McGraw-Hill Book Co.

Tiffany, L. H. 1937. Oedogoniales, Oedogoniaceae. North American Flora, 11, Part I. 102 pp. New York Botanical Garden.

Tiffany, L. H., and Britton, M. E. 1952. The algae of Illinois. 407 pp. 108 pls. Univ. Chicago Press.

Tilden, Josephine E. 1935. The algae and their life relations. $550 \mathrm{pp}$. Figs. 1-257. Minneapolis.

Transeau, E. N. 1951. The Zygnemataceae. Ohio State University Press, Columbus, Ohio.

Wolle, F. 1887. Freshwater algae of the United States. Vols. 1, 2. Bethlehem, Pa.

Wolle, F. 1892. Desmids of the United States and list of American Pediastrums. Bethlehem, Pa. 


\section{PICTURED-KEYS TO THE COMMON GENERA OF FRESH-WATER ALGAE}

la Plants large (macroscopic), up to 40 or more $\mathrm{cm}$. high, growing erect, with stem-like whorled branches and forked "leaves" clearly visible to the unaided eye. Fig. $1-3 \ldots .$. . Family Characeae....2

Ib Plants microscopic, or if macroscopic with cellular structures and branches not visible to the unaided eye, or scarcely so........

$2 \alpha$ Branching unsymmetrical, with dense heads of short branches and scraggly longer ones; microscopically showing globular antheridia (male organs) lateral, beside the oval oogonia (female organs). Fig. 1 . ............................. TOLYPELLA

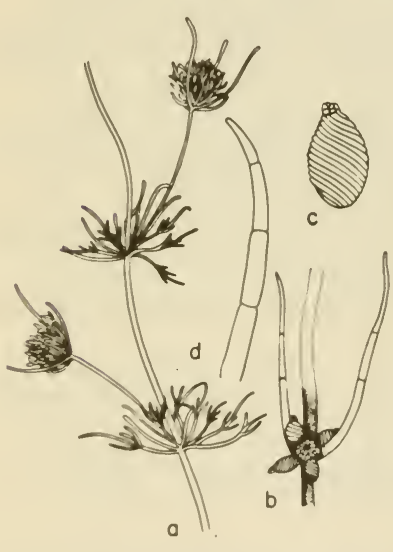

Figure 1

Fig. 1. Tolypella intricata (Trentep.) v. Leonh. $a$, Portion of plant showing habit of branching; $b$, a node showing four oogonia and one antheridium; $c$, an oogonium showing the 'crown' cells; d, tip of branch.

A rather rare plant in North America, occurring in hard water lakes mostly. It appears very much like Chara (Fig. 2) in need of a hair-cut but unlike Chara it does not form dense beds in the bottom of ponds and streams, but occurs singly or in sparse clusters. Under the hand lens Tolypella shows its true relationship to Nitella (Fig. 3) in not having column-like or fluting cells along the stem and branches.

2b Branching symmetrical with rather evenly spaced whorls of equallength branches at nodes of the stem; antheridia above or below

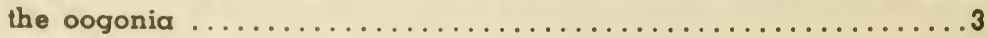

- Some of the illustrations used in this volume have been redrawn from figures previously published by the outhor. 
3a Plants coarse and usually rough with lime; ill-smelling (garlic or skunk odor); microscopically showing spherical antheridia lateral and below the oval oogonia; branches with long, corticating colum. nar cells about the main axial cell. Fig. 2...........CHARA (Chara coronata Ziz., however, has no corticating cells.)

Fig. 2a. Chara canescens Lois.-Des. $\bar{A}$ portion of a plant in which thorn-like cells arising from the corticating elements give a spiny appearance; $b$, one node of Chara excelsa Allen showing the oval oogonium above, and the globular antheridium below.

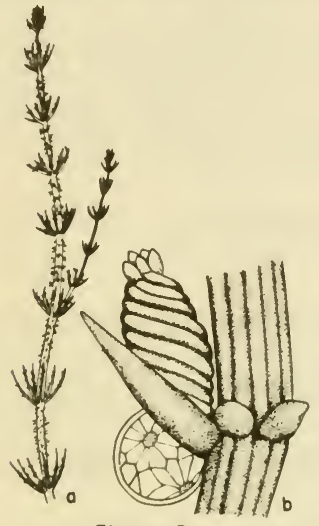

Figure 2

Most of the species, of which there are many, occurring in North America are world-wide in their distribution. They are to be found usually in streams which are slow-flowing or in lakes in which there is considerable calcium. Some species especially are active in depositing lime upon themselves and are so harsh to the touch as to earn the common name "stone-wort." Marl and other kinds of calcareous deposits may be formed largely by Chara over long periods of time.

$3 \mathrm{~b}$ Plant delicate, or if relatively stout, not roughened with lime; dark green, not ill-smelling: microscopically with globular antheridia terminal on a short pedicel within a cluster of branches and above the oogania; main axis not corticated. Fig. 3.........NITELLA

Fig. 3a. Nitella tenuissima (Desv.) Kuetz., habit; b. Nitella flexilis (L.) C. A. Agardh, portion of plant showing habit of branching.

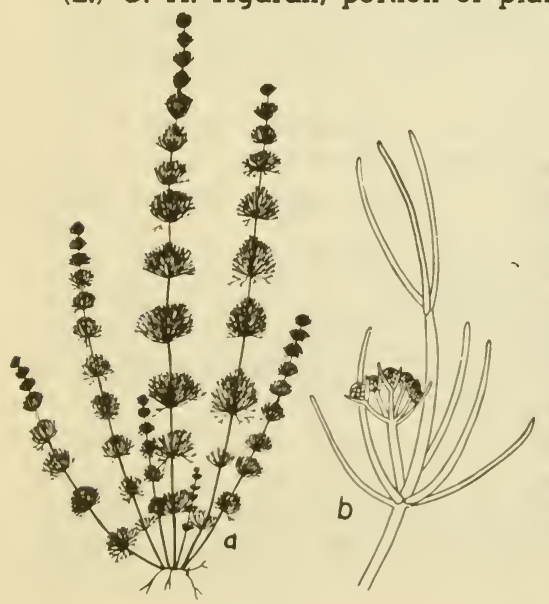

Species of Nitella are not seen so often as are the Charas because they usually grow more deeply. thriving in soft water or acid lakes rather than in hard water situations. Some species occur in bog lakes that are darkly stained with humic acids and are collected only by dredging with a plant hook. The plants are greener than Chara and are not encrusted with lime; are not ill-smelling. 
4a (1) Cells containing chloroplasts (bodies with green pigment predominating), or chromatophores (bodies with colors other than green

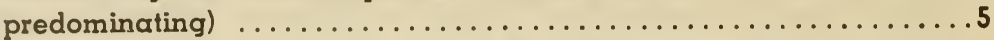

$4 \mathrm{~b}$ Cells without chloroplasts and chromatophores, with pigments in solution and more or less evenly diffused throughout the entire protoplast........Subdivision Myxophyceae............. 376

5a Plant grass- or leaf-green to gray-green; photosynthetic product starch (iodine test positive), or paramylum (iodine test negative), or floridean starch in the freshwater red algae which are greenish

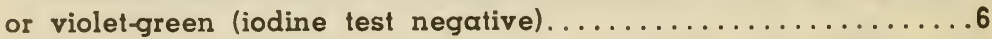
Note: Because some Chlorophyta, or essentially green algae are often tinged with red or yellow (the green color sometimes masked by the other color), and because normally violet-green Rhodophyta often appear green to the observer, the reader should compare plants being keyed with:

No. $22 \alpha$ in the key, Haematococcus, a red unicellular, motile organism; No. $60 a$ in the key, Botryococcus, colonial green alga in a brown, nearly opaque mucilage;

No. 119a in the key, Rhodochytrium, a red unicell in the tissues of higher plants.

No. 238a in the key, Trentepohlia, an orange-colored member of the Chlorophyta.

No. 239 a in the key, Batrachospermum, a filamentous member of the Rhodophyta which is gray- or violet-green;

No. 256a in the key, Cephaleuros, a filamentous, semiparasitic and nearly colorless member of the Chlorophyta;

No. 265a in the key; Leptosira, a yellowish-green filamentous member of the Chlorophyta; and

No. $304 a$ in the key, Botrydium, a green, balloon-like vesicle, belonging to the Chrysophyta.

Also, see Trachelomonas, Fig. 5, identified by a brown shell which incloses a green protoplast, and Dinobryon, Fig. 243, which has a colorless, cone-shaped envelope (lorica) containing a protoplast which appears greenish.

5b Plant not qrass- or leaf-green (but see Botrydium, Fig. 214, which is green but belongs to the Chrysophyta (yellow-green algae); color light green, violet-green, yellowish or brown; iodine test for starch

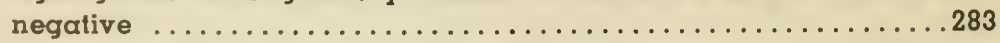

$6 a$ Plants swimming in the vegetative state, solitary or colonial. (Preserved specimens should be examined for 2 or more minute protuberances at the anterior end of the cell which locate the position of the flagella (organs of locomotion) that may have been retracted or lost). Use $5 \%$ glycerine for mounts. See fig. $17 \ldots \ldots \ldots \ldots 7$

$6 \mathrm{~b}$ Plants not motile in the vegetative state: (check to be sure cell is not a swimming organism at rest; see Trachelomonas, Fig. 5 which although motile, is commonly found as a non-motile, brown shell (lorica) from which the swimming protoplast has escaped): solitary. colonial or filamentous. . . . . . . . . . . . . . . . . . . 35 
7a Cells broadly ovoid or oval in outline, flattened as seen from the side; chloroplasts radiately disposed at the periphery of the cell; flagella 2, 1 trailing. Fig. 4. Division Chloromonadophyta..... GONYOSTOMUM

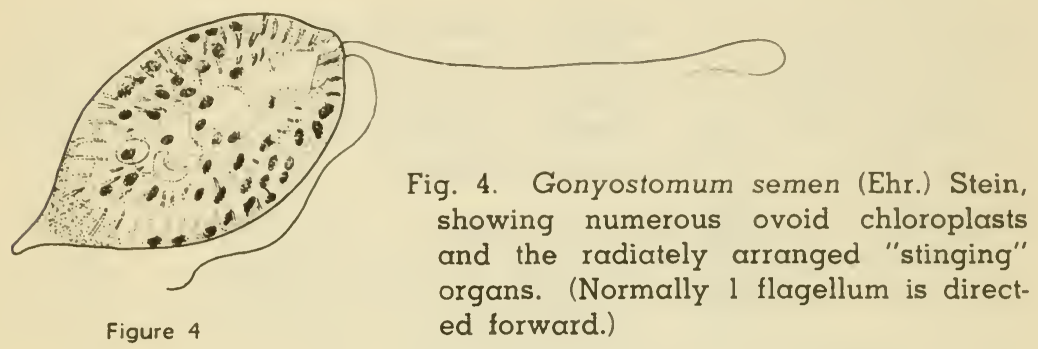

This rare swimmer occurs mostly in acid bogs and in shallow lakes, accompanying certain species of Euglena (See Fig. 8). Under the microscope it reminds one of a flat, green bottle; usually is quiet in the microscope fie d so that its unique internal structure can be studied easily. It has sudden, jerky movements for short distances.

7b Cells round or oval when seen in both front and side view, sometimes slightly flattened, but with flagella directed forward; chloroplasts not arranged as above; flagella $2,4,1^{*} \ldots \ldots \ldots \ldots \ldots . .$.

$8 a$ Cells with numerous, disc-like (rarely ribbon-like chloroplasts); food reserve in the form of variously shaped, colorless or white paramylum bodies (See Fig. 6) which do not stain blue-black with iodine; slow-moving by a stout flagellum (See Fig. 8); a red eyespot usually evident....... Division EUGLENOPHYTA.........9

$8 \mathrm{~b}$ Cells with 1 cup-shaped or star-shaped chloroplast, usually containing one or several conspicuous pyrenoids (doughnut-like, shiny bodies buried in the chloroplast or on its surface); food reserve starch, iodine test positive; lens-shaped eye-spot usually evident; actively swimming with fine, often obscure flagella. (See Fig.13). (Add 5\% glycerin to mount to slow down organisms for ob-

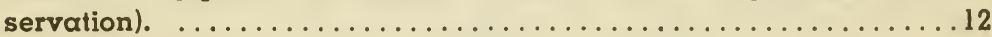

*Colorless, one-celled, swimming relatives of Euglena are not included here. Paranema and Astasia are examples of these strictly protozoan-like genera. Peranema has one stout, rather rigid flagellum extended anteriorly, and a fine, inconspicuous one appressed close to the cell body. Astasia is highly plastic; swims by one flagellum; has a prominent gullet in the anterior end. 
9a Cells inclosed in a brown shell (test), variously shaped, (round, oval, or flask-shaped), often with a collar about the aperture through which a single flagellum extends. (The variously shaped cells of this genus frequently are found empty, yellow to dark brown, smooth or decorated.) Fig. 5............TRACHELOMONAS

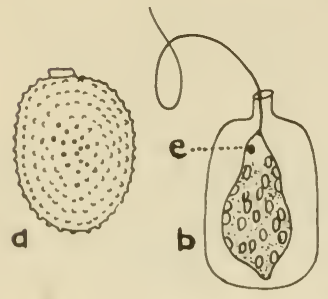

Figure 5

Fig. 5a. Trachelomonas granulosa Playf., a short-collared species which has a warty shell; b. Trachelomonas euchlora (Ehr.) Lemm., protoplast within shell, showing eyespot, chloroplasts, and flagellum.

There are several hundred species of Trachelomonas, each showing a differently shaped shell, or lorica, and each having its own special style of decoration. Usually the loricas are found empty, brown, yellow, or sometimes nearly colorless (determined by the amount of iron present in the shell), intermingled with the miscellaneous algae that grow in shallow water or bogs, or among weed beds near the shores of lakes.

$9 \mathrm{~b}$ Cells not inclosed in $a$ test..........................

10a Cells flattened as seen from the side and often twisted; broadly fusiform or nearly round in outline when seen from the front; paramylum in the form of one to several 'doughnut' rings, or discs. Fig. $6 \ldots \ldots \ldots \ldots \ldots \ldots \ldots \ldots \ldots \ldots \ldots \ldots \ldots \ldots \ldots \ldots$ PHACUS

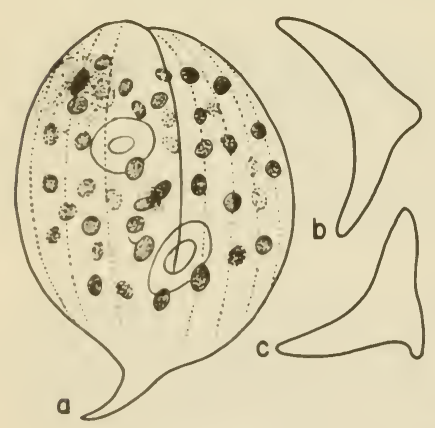

Figure 6

Fig. 6a. Phacus curvicauda Swir., front or ventral view showing eye-spot, chloroplasts, and 2 ring-shaped paramylum bodies (food reserve): b, c, Phacus triqueter (Ehr.) Duj. as seen in end view, the triangular shape being produced by the dorsal flange.

Although some species are spirally twisted and 'top-shaped' most are flat or at most are only slightly saucershaped or pancake-like, with a long or short tail-piece. The rings of storage material are usually very conspicuous and so large as 'to fill nearly the entire diameter of the cell.

10b Cells not flattened, round in cross section; either elongate-fusiform or oval to round or somewhat pear-shaped in outline; paramylum bodies different from above....................11 
lla Cells round, oval or pear-shaped, rigid, fixed in shape when swimming: paramylum in the form of 2 large lateral rings; tailpiece, if present, usually in the form of a short, sharp protrusion from the rounded posterior end of the cell. Fig. $7 \ldots \ldots \ldots \ldots$.

LEPOCINCLIS
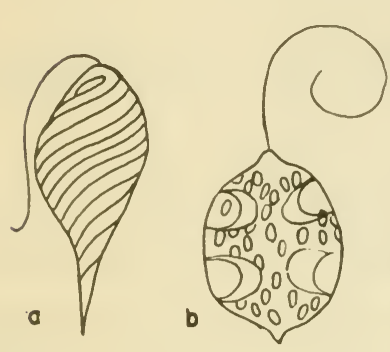

Figure 7

Fig. 7a. Lepocinclis acuta Presc., showing spiral markings of the periplast (membrane); b, Lepocinclis glabra fa. minor Presc., showing four lateral, band-like paramylum bodies.

Round when seen on end, rather than flat like Phacus (Fig. 6). The siorage material in most species forms 2 rings that lie along the side walls of the cell. Often with Euglena (Fig. 8), but much more active.

11b Cells often changing shape when swimming (rigid in some species), elongate, nearly cylindrical, or fusiform: paramylum in the form of a few and large, or numerous, small, colorless rods or sticks; tail-piece formed by gradual narrowing of the cell. Fig. 8. EUGLENA

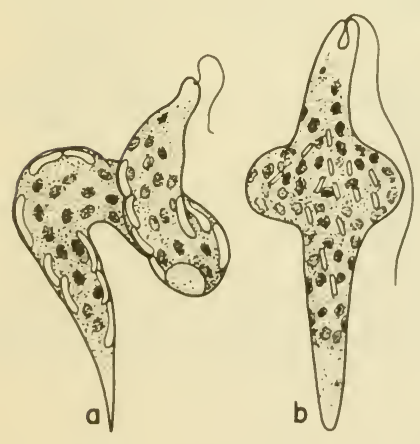

Figure 8

Fig. 8a. Euglena convoluta Korsch., showing lateral paramylum plates as seen on edge, one in flat view; $b, E$. elastica Presc. Both of these are metabolic species (changing shape while in motion) whereas some forms are rigid.

Although usually green, these elongate, slowly moving species sometimes are colored red because of a pigment, haematochrome. A pond or slough may have $a$ bright red film over the surface caused by Euglena which seem to produce the pigment in response to intense light.

12a (8) Plant a colony of 4 or more cells, either closely adjoined, or free from one another within a gelatinous envelope.............. Division CHLOROPHYTA (in the main) .................13

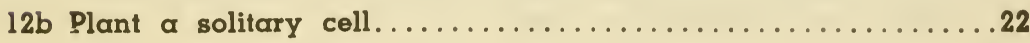


$13 \alpha$ Cells arranged in a plane, forming a plate (flat or twisted). . . .14

13b Cells arranged to form a spherical, ovoid or spheroidal colony. . 15

14a Colony horseshoe-shaped, flat or twisted. Fig. 9...PLATYDORINA

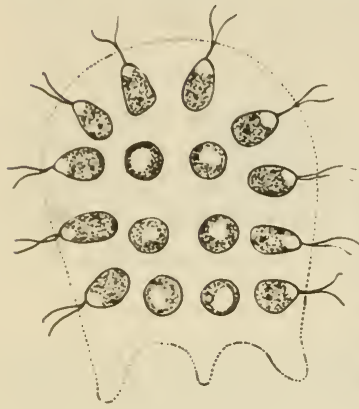

Figure 9

Fig. 9. Platydorina caudatum Kofoid. The flagella of the organism in the center of the colony are directed vertically to the surface.

Although rare this plant can be easily identified by the flattened, slightly twisted, horseshoe-shaped colony. It is to be found in the same habitats with other members of the Volvocaceae, Eudorina (Fig. 17), and Pandorina (Fig. 14).

14b Colony a circular or subquadrangular plate. Fig. 10,.. GONIUM

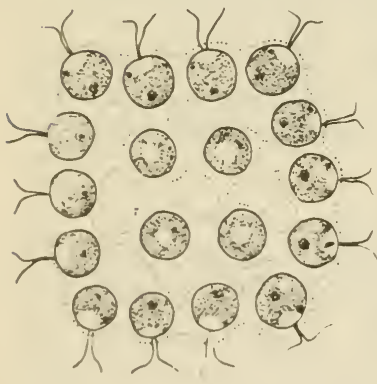

Figure 10
Fig. 10. Gonium pectorale Muell. An 18celled colony.

The number of cells in a colony may vary. Other species (with cells shaped differently) may have as few as 4 or as many as $32-64$ individuals. The rectangular plates tumble over and over as the colony swims through the water.

15a Colony oblong or pear-shaped, with cells densely clustered and all directed anteriorly, without an enveloping colonial mucilage.. 16

15b Colony globular or ovoid; cells inclosed in a mucilaginous sheath, but not all directed one way....................... 18 
16a Colonies small (2-4 cells). Fig. $11 \ldots \ldots \ldots \ldots$ PASCHERIELLA

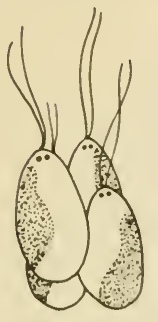

Figure 11

Fig. 11. Pascheriella tetras Korsch. Cells showing eye-spot (lateral) and subflagellar vacuoles at the apex.

Rare. Is to be looked for in small rain water pools and catch basins of temporary duration.

16b Colonies of $8-16$ cells........................... 17

17a Cells with 4 flagella, arising from a protuberance at the broad end. Fig. $12 \ldots \ldots \ldots \ldots \ldots \ldots \ldots \ldots \ldots$ SPONDYLOMORUM

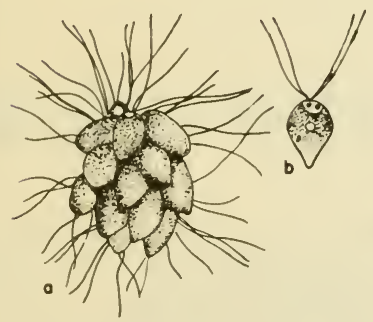

Figure 12
Fig. 12. Spondylomorum quaternarium Ehr. $a$, colony; $b$. single organism showing posterior eye-spot and subflagellar vacuoles.

Pear-shaped cells huddled together with their broad ends all directed the same way; eye-spot is posterior rather than anterior as in most of its relatives. The 4 flagella are difficult of determination except under favorable optical conditions.

17b Cells with 2 flagella. Fig. 13........... CHLAMYDOBOTRYS

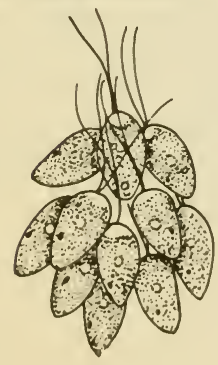

Figure 13
Fig. 13. Chlamydobotrys gracilis Korsch. A colony of individuals with posterior eye-spots.

Like Spondylomorum (Fig. 12) cells of this colonial organism are closely grouped; have 2 long flagella and a conspicuous eye-spot. 
18a (15)-Colony spheroidal or oval; cells pear-shaped, crowded together with broad ends all directed outwardly. Fig. $14 \ldots \ldots \ldots$

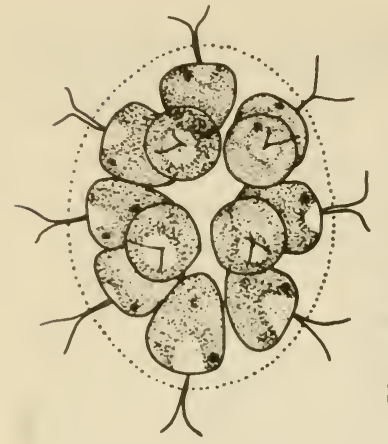

Figure 14

Fig. 14. Pandorina morum Bory. Cells are pear-shaped and often are more compactly arranged than shown here.

A tumbling colony in which pear-shaped cells are closely compacted within a spheroidal or oval gelatinous sheath. Often colonies are to be seen in which all individuals have divided to form each a daughter colony. There is one other species in the United States, (possibly a Eudorina Fig. 17).

18b Colony globular or broadly ovoid; cells not crowded but evenly spaced (even though close together).................. 19

19a Colonies large, containing hundreds or thousands of cells. Fig. 15 VOLVOX

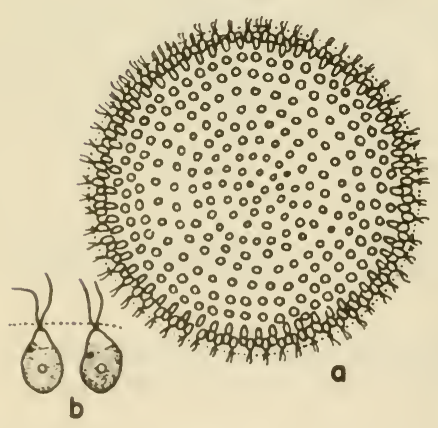

Figure 15
Fig. 15. Volvox tertius Meyen. a. Colony showing only vegetative cells; $b$, two organisms showing eye-spot. Other species have colonies containing a larger number of cells, and some have intercellular connections.

This globular colony containing thousands of cells is usually easily seen with the unaided eye. It occurs in water that is rich in nitrogenous substances (frequently) and sometimes causes "blooms" of short duration (two or three days during summer months). 
20a Cells fusiform with sharply pointed lateral processes or extensions of the protoplast. Fig. $16 \ldots \ldots \ldots \ldots \ldots$. . . . .

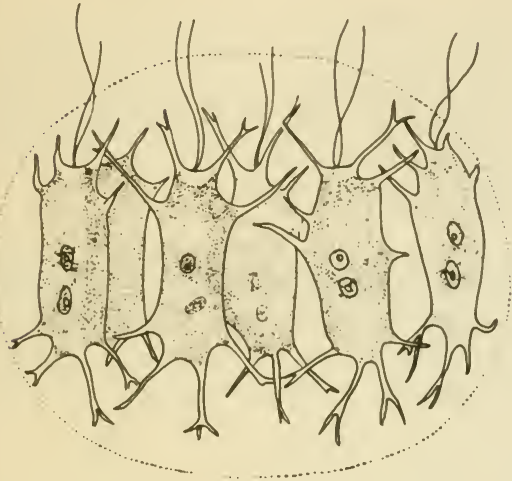

Figure 16
Fig. 16. Stephanosphaera pluvialis Cohn. Oval colony with organisms forming a median band. The cells commonly show 2 pyrenoids (starchstoring bodies).

Like Pascheriella (Fig. 11) this plant occurs in small, temporary pools; is easily identified by its irregularly shaped cells forming a transverse belt in a compressed, spheroidal gelatinous sheath.

20b Cells round or ovoid, without lateral processes...........21

21a Cells all the same size within the colony. Fig. 17...EUDORINA

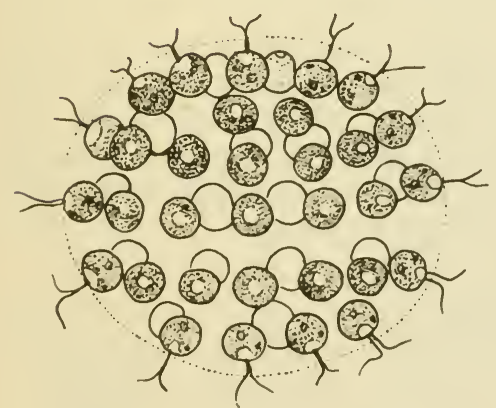

Figure 17
Fig. 17. Eudorina elegans Ehr. In this species the cells have a tendency to arrange them. selves in transverse bands or tiers. Occurs along with Volvox (Fig. 15) and Pleodorina (Fig. 18).

Unlike Pandorina (Fig. 14) the cells are round or oval and rather evenly spaced within the colonial mucilage. Eudorina unicocca G. M. Smith is another species which has been reported from the United States, differentiated by the colony showing a slight polarity with the sheath forming lobes at the posterior end. 
$21 \mathrm{~b}$ Cells of 2 sizes within the same colony, the smaller arranged at one pole of the envelope. Fig. $18 \ldots \ldots \ldots \ldots \ldots$ PLEODORINA

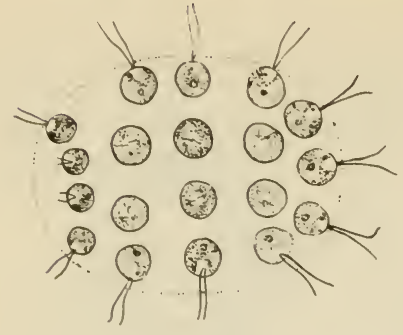

Figure 18

Fig. 18. Pleodorina illinoisensis Kofoid. Another common species ( $P$. californica Shaw) has about one-half of the cells larger and with reproductive capacity, the smaller cells being strictly vegetative.

Colonies are perfectly spherical like most Volvox (Fig. 15) but have many fewer cells (usually 128). Although Pleodorina often occurs in the same habitat with Volvox it can be distinguished quickly by the two sizes of cells in the colony.

22a (12)-Protoplast at a considerable distance within the cell wall and connected to it by fine, radiating processes; cells with a mass of red pigment often present in the center of the protoplast (sometimes masking the green color); usually encysted, forming rustcolored encrusting growths in bird baths and cemented pools. Fig. 19 .HAEMATOCOCCUS

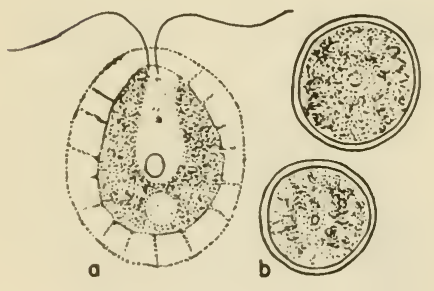

Figure 19

Fig. 19. Haematococcus lacustris (Girod.) Rostaf. a, swimming cell showing protoplast with radiating processes; $b$, cysts (which usually are brick-red in color).

The wide gelatinous wall with fibrils of protoplasm extending out from the cell membrane identify this motile organism. It is widely distributed and $\alpha$ common inhabitor of garden pools and catch basins in rocks.

22b Cells not as above; free-swimming

23a Cells with $\alpha$ definite (although sometimes thin) wall, often with $\alpha$ gelatinous sheath

23b Cells without a definite wall; chloroplasts lying against the cell membrane: gelatinous sheath wanting................. 32 


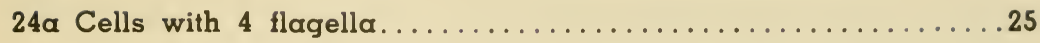

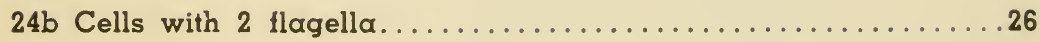

$25 a$ Cells flattened when seen from the side or from the top. Fig. 20. .PLATYMONAS

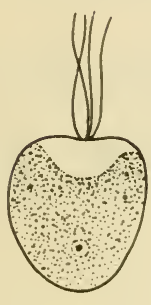

Figure 20

Fig. 20. Platymonas elliptica G. M. Smith. (Redrawn from Smith.)

Although usually found in brackish water, this genus contains at least one species that appears in freshwater. To make identification the cells should be seen from the top or side to determine whether they are flattened.

$25 \mathrm{~b}$ Cells round when seen from the side or from the top. Fig. $21 \ldots$. CARTERIA

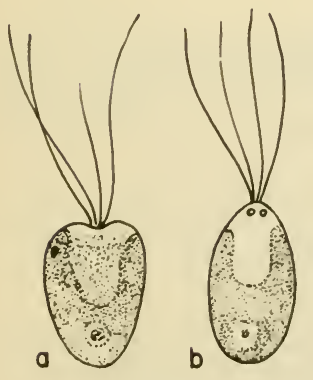

Figure 21
Fig. 2la. Carteria cordiformis (Carter) Dies.; b, Carteria Klebsii Dill.

Like Platymonas (Fig. 20) this genus is characterized by having four flagella but the cells are round when seen in end view. The chloroplast is variable in shape and may not appear as shown in the illustration. It may be a thin plate along the wall, cup-shaped and covering most of the wall except at the anterior end, or $\mathrm{H}$-shaped. 
27a. Envelope roughened or warty, the flanges forming 4 lobe-like extensions when seen from the top or side. Fig. 22

WISLOUCHIELLA
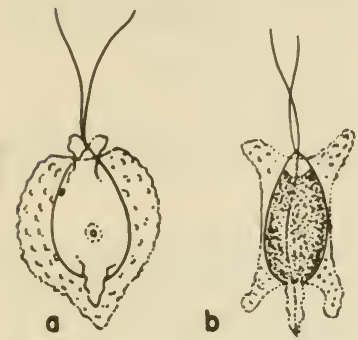

Fig. 22. Wislouchiella planctonica Skvor. $a$, 'front' view; $b$, side view.

Named for the biologist Wislouch, this biflagellated organism is identified quickly by the oddly-shaped lobes or processes of the wall which extend in several planes. Rare.

Figure 22

27b Envelope not roughened, or if roughened, without lobe-like extensions

28a Envelope composed of 2 overlapping pieces, the seam showing when the vegetative cell is seen from the side. Fig. 23.

PHACOTUS
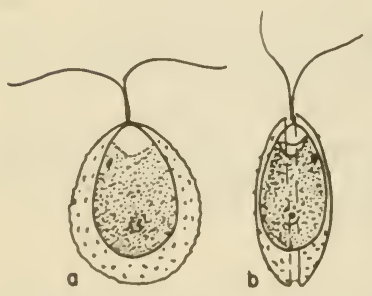

Figure 23
Fig. 23. Phacotus lenticularis (Ehr.) Stein. a. 'front' view; b, side view showing bivalve structure of cell wall.

This genus is relatively rare, but is often abundant in collections from habitats where it occurs. It is both euplanktonic (a true plankter) and tychoplanktonic and may occur in river as well as in lake collections. 
28b Envelope with 2 overlapping sections which do not show except when the cell is in the process of dividing; envelope 4-angled when seen from the 'front.' Fig $24 \ldots \ldots \ldots \ldots \ldots \ldots$. PTEROMONAS

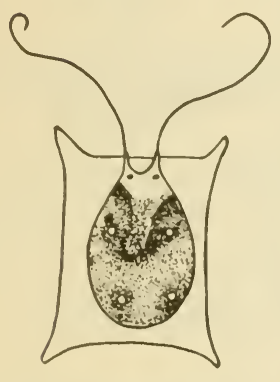

Figure 24

Fig. 24. Pteromonas aculeata Lemm.

This genus takes its name from the winged appearance of the envelope. Although there are about 7 species known, the most common perhaps is Pteromonas aculeata Lemm. recognizable by the rectangular appearance as seen in 'front' view. Like Phacotus (Fig. 23) this species sometimes occurs in the plankton of rivers. See Scotiella (Fig. 127), a genus which has been regarded by Pascher as belonging to Pteromonas.

29a (26) Cells elongate or fusiform. Fig. $25 \ldots \ldots$ CHLOROGONIUM

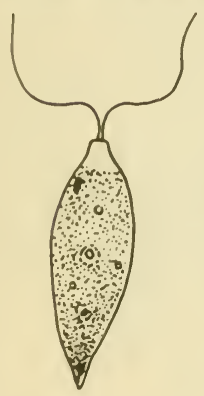

Fig. 25. Chlorogonium sp.

Of the 8 species known for this genus only 2 are reported from the United States. They are all more elongate than any other members of the order Volvocales. Usually found in swamps and shallow ponds. they sometimes appear abundantly in laboratory aquaria.

Figure 25

29b Cells round, oval or angular.

$30 a$ Cell wall with lump-like protuberances or short lobes. Fig. 26 LOBOMONAS

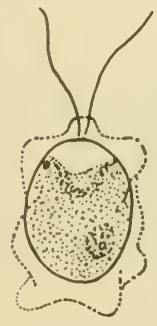

Fig. 26. Lobomonas rostrata Hazen.

The irregular lumpy appearance of this genus is its chief characteristic. The organisms appear in the same habitat with Haematococcus (Fig. 19), i.e., temporary rain water pools and cement basins.

Figure 26 
3la Gelatinous envelopes shaped similarly to the protoplasts. Fig. 27. CHLAMYDOMONAS

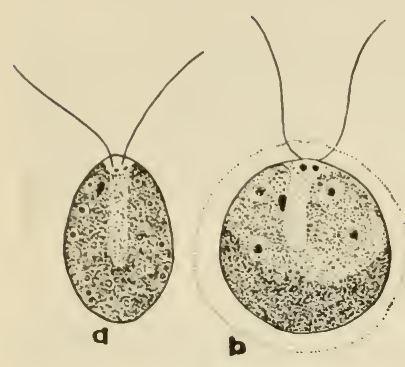

Figure 27

Fig. 27a. Chlamydomonas polypyrenoideum Presc.; b, Chlamydomonas sphagnicola Fritsch \& Takeda, a species with bipapillate protrusions at the anterior end of the sheath.

Whereas this common genus is represented by approximately 175 described species, it is doubtful that they are all distinct. Unless specimens are given careful study they may be confused with other minute biflagellate green cells belonging to other genera, or with zoospores. Variations of the same species may be described under different names. The species of this genus are encountered more frequently than any other members of the Volvocales and are to be found in a great variety of habitats, from the plankton of lakes to the green water of rain barrels. A favorable place for them is the barnyard pool or watering trough. C. nivalis (Bauer) Wille produces red snow at high altitudes.

$31 \mathrm{~b}$ Gelatinous envelope and protoplast different in shape from one another. Fig. $28 \ldots \ldots \ldots \ldots \ldots \ldots \ldots \ldots \ldots$. . . . . . . . .

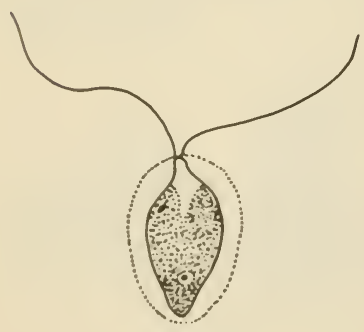

Figure 28
Fig. 28. Sphaerellopsis fluviatilis Pascher.

This genus probably should be classified under Chlamydomonas although specialists separate its 2 species on the basis of the very wide gelatinous sheath being different in shape from that of the protoplast. It occurs in the tychoplankton of small lakes, and in pools. 


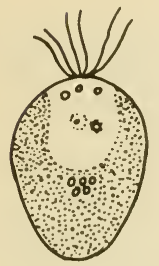

Figure 29

Fig. 29. Polyblepharides fragariiformis Hazen, showing 3 of the 4 contractile vacuoles at the anterior end. (Redrawn from Hazen.)

Apparently there are only 2 species on record for this genus. They possess 6-8 flagella and several contractile vacuoles at the anterior end.

32b Flagella 2-4

33a Flagella 2

33b Flagella 4. Fig. 30

PYRAMIMONAS

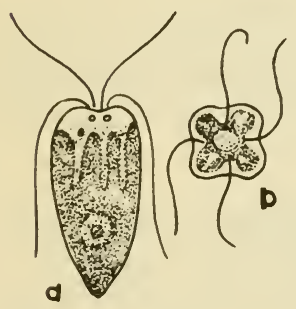

Figure 30

Fig. 30. Pyramimonas tetrarhynchus Schmar. $a$, 'front' view; $b$, end view showing points of attachment of the flagella.

This is Pyramidomonas of some authors; contains at least 8 species all of which are 4-lobed when seen in end view, with a flagellum attached in each of the four depressions between th'” lobes.

$34 \alpha$ Cells ovoid but with lobes or flanges, appearing 6-angled when seen in end view. Fig. $31 \ldots \ldots \ldots \ldots \ldots$. STEPHANOPTERA

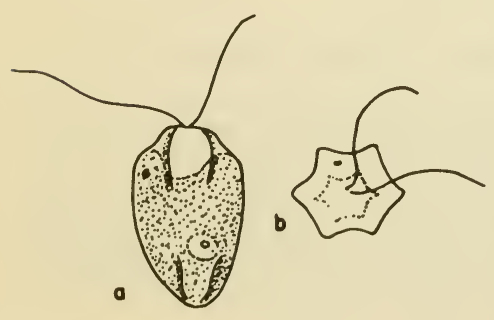

Figure 31
Fig. 31. Stephanoptera gracilis (Artari) G. M. Smith. a, 'front' view; $\mathrm{b}$, end view, showing point of attachment of flagella.

This genus takes its name from the fact that it is crown-shaped or 6 lobed when seen on end; the flagella being centrally attached in the anterior end. 


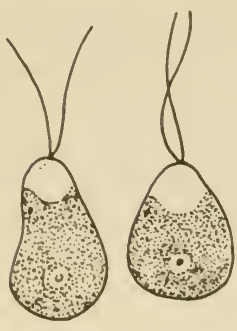

Figure 32
Fig. 32. Dunaliella salina Teodor. Two differently shaped individuals.

This species and $D$. viridis Teodor. are apparently the only ones described thus far for the genus, but they are widely distributed judging from reports of them in different parts of the world, occurring in brackish or saline waters.

$35 a$ (6). Plant a filament (cells in continuous or interrupted series) with or without branches; or a flat expanse or attached cushion with the branches closely appressed so that the basic filamentous plan is not clearly evident; or a tubular, thread-like thallus without cross walls (coenocytic)............................ 189

35b Plants not filamentous, but solitary cells or a colony of 2 or more cells inclosed by mucilage or by an old mother cell wall (see Oocystis, Fig. 85), or cells variously adjoined to one another (Scenedesmus, Fig. 74; Pediastrum, Fig. 70)................. 6

$3 \subseteq \simeq$ Cells solitary or gregarious but not adjoined to form colonies. . 109

$36 \mathrm{~b}$ Cells adjoined or arranged in colonies....................

37a Colony composed of 2 trapezoidal cells adjoined along their broad bases. Fig. $33 \ldots \ldots \ldots \ldots \ldots \ldots \ldots \ldots \ldots \ldots \ldots \ldots \ldots \ldots \ldots$ EUATROPSIS

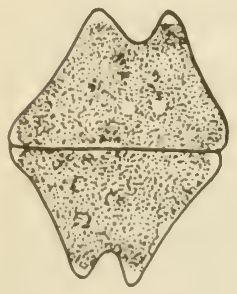

Figure 33
Fig. 33. Euastropsis Richteri (Schmid.) Lag.

This is the only species of the genus on record. The two cells which compose the colony appear much like those of Pediastrum (Fig. 70) but are never more than this number joined together. Euastropsis occurs in the tychoplankton; is rare but widely distributed. 
37b Colony composed otherwise.

38a Colony composed of cells invested by a common mucilage (see Oocystis, Fig. $85 \mathrm{~b}$, with cells inclosed by old, expanded mother cell wall, not by mucilage)............................ 39

38b Colony composed of an aggregate of cells not inclosed by mucilage, but may be inclosed by old mother cell wall or fragments

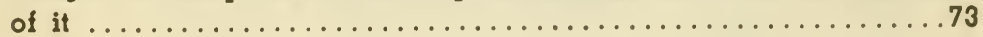

$39 a$ Colony attached or adherent..................... 40

$39 \mathrm{~b}$ Colony free-floating or entangled among other algae, but not growing attached (frequently algae usually attached become separated from their substrate. Look for attaching stalk, disc or other evidence of the plant having been once attached)............49

40a Colonies in the form of compact packets among the epidermal cells of aquatic plants. Fig. $34 \ldots \ldots \ldots \ldots \ldots$ CHLOROSARCINA

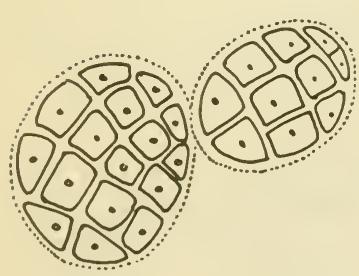

Figure 34

Fig. 34. Chlorosarcina consociata (Klebs).G. M. Smith.

This packet-like arrangement of cells is remindful of the genus Sarcina among the bacteria. There are 3 species, usually free-living but one that is most frequently seen occurs in the tissues of such aquatic plants as Lemna. Old, colorless specimens of Lemna often show this and other endophytic algae (Chlorochytrium Lemnae, Fig. 94).

$40 \mathrm{~b}$ Colonies not endophytic in the tissues of aquatic plants

4 la Colonial mucilage sac-like, balloon-shaped or intestiniform, often macroscopic

$41 \mathrm{~b}$ Colonial mucilage of other shapes, or if sac-like, microscopic..43 
42a Aquatic; cells without individual sheaths definitely arranged in 4 's (or sometimes in 2's) mostly at the periphery of the common mucilage; under favorable optical conditions often showing long, fine, hair-like extensions (pseudocilia or false flagella). Fig. 35.

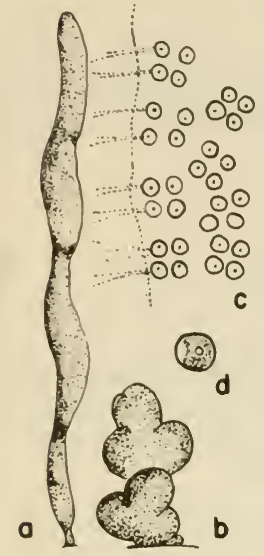

Figure 35

Fig. 35a. Tetraspora cylindrica (Wahl.) C. A. Agardh, habit of colony; b, Tetraspora gelatinosa (Vauch.) Desvaux, habit of colony; c, arrangement of Tetraspora cells; d, single cell showing cup-shaped chloroplast.

Early in the spring or throughout the summer in cold running water gelatinous, balloon-like or intestiniform strands of Tetraspora may be found attached to stones or to gravel, sometimes building masses 2 or 3 feet in length. Most of the dozen or so recognizable species are macroscopic but a few appear as microscopic, floating thalli. When the colonies are young and if care is used in obtaining ideal optical conditions, the long fine (often shadowy) pseudocilia are discernible.

42b Terrestrial (usually); cells sometimes with indistinct sheaths, not definitely arranged in 4 's; without pseudocilia. Fig. $36 \ldots \ldots$.
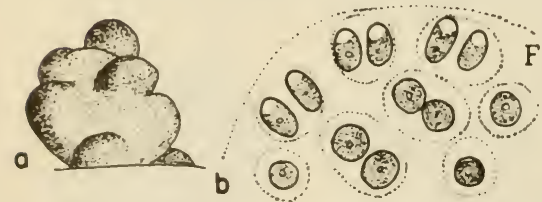

Figure 36

Fig. 36. Palmella miniata Liebl. a, habit of colony; $b$, portion of colony showing arrangement of cells and individual cellular sheaths.

This plant forms lumpy gelatinous masses, $2-8$ or more millimeters in diameter on damp soil or on rocks, especially about water falls. The cells of $P$. miniata are often red with the pigment haematochrome, whereas $P$. mucosa (without individual cellular sheaths of mucilage) is always green. 
43a (41) Colony balloon-like or pear-shaped, narrowed at base to form a stalk-like attachment; pseudocilia usually visible. Fig. $37 \ldots$ APIOCYSTIS

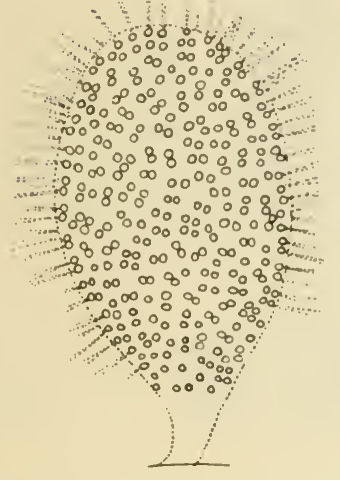

Fig. 37. Apiocystis Brauniana Naeg. Diagram of a colony showing cell arrange. ment and pseudocilia.

This plant is always in the form of a microscopic thallus growing attached to filamentous algae or to stems of aquatic plants. The cells are arranged somewhat irregularly in four's and under favorable conditions show pseudocilia like Tetraspora. (Fig. 35.)

Figure 37

43b Colony some other shape; pseudocilia absent

44a Colonial mucilage forming a fusiform shaped envelope; cells similarly shaped as the envelope, with long axes more or less parallel. Fig. 38 . ELAKATOTHRIX

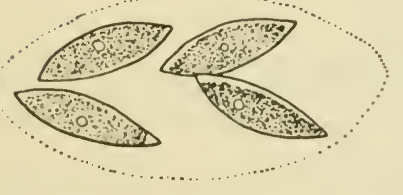

Figure 38

Fig. 38. Elakatothrix viridis (Snow) Printz.

Somewhat 'cigar'-shaped cells placed end to end in pairs within a fusiform, gelatinous sheath. E. gelatinosa Wille has both ends of the cell pointed whereas other species have the adjoined poles truncate. In one of the three species found in this country, Elakatothrix americana Wille, the gelatinous colonial sheath is irregularly lacy or fringed.

44b Colonial mucilage not fusiform 
45a Cells cylindrical or elongate-ovoid, scattered throughout amorphous mucilage. Fig. $39 \ldots \ldots \ldots \ldots \ldots \ldots \ldots \ldots \ldots \ldots \ldots \ldots \ldots$ COCC

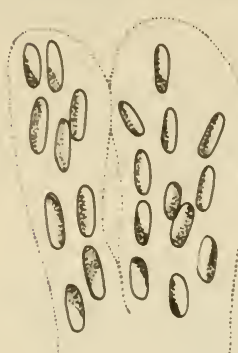

Figure 39

Fig. 39. Coccomyxa dispar Schmidle, cells in the tips of gelatinous strands.

There are three recorded species of this genus but only Coccomyxa dispar Schm. seems to have been found in this country, forming gelatinous masses of varying extent on damp soil, on wet wood, or more rarely free-floating. It has been found attached in $a$ wooden flume of swiftly flowing waier.

45b Cells shaped otherwise

46a Cells elliptical or nearly spherical, arranged in 2's and 4's within ungelatinized walls of mother-cell; pigment spot (eye-spot) usually evident. Fig. 40...PALMELLA-STAGE OF CHLAMYDOMONAS

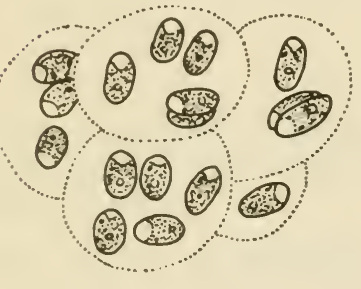

Figure 40

Fig. 40. Palmella-stage of Chlamydomonas.

Chlamydomonas (Fig. 27) often becomes quiescent in unfavorable habitats, or as a normal stage in its life history. The cells adhere to a substrate, lose their flagella, but continue to divide, sometimes forming extensive gelatinous masses. The cells are arranged in 2's or 4's and are surrounded by mucilaginous sheaths, thus somewhat re-

sembling Palmella (Fig. 36). In this form Chlamydomonas is often mistaken for Gloeocystis (Fig. 41). Laboratory aquaria often contain Chlamydomonas in this stage. The cells may become actively motile again by developing new flagella.

46b Cells spherical (sometimes oval) irregularly scattered throughout mucilage; orange-colored oil globules sometimes present; red eyespot lacking .47 
47a Cells inclosed by concentric layers of mucilage (individual cell sheaths distinct). Fig. $41 \ldots \ldots \ldots \ldots \ldots \ldots$. . . . . . .

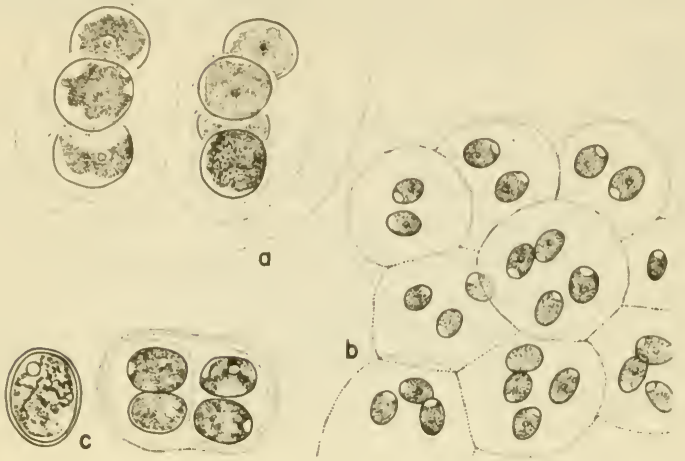

Figure 41

Fig. 4 la. Gloeocystis gigas (Kuetz.) Lag.; b.Gloeocystis ampla (Kuetz.) Lag.; c, Gloeocystis major Gerneck, showing dense, cup-shaped chloroplast.

There are several species of Gloeocystis and all are very common. They are not very distinctive plants and therefore many small, round green cells, especially when inclosed in mucilage, belonging to other genera may be mistaken for them. The concentric layers of mucilage about the cells provide a helpful character for identification. Gloeocystis ampla (Kuetz.) Lag. does not have layers of mucilage, however, but this free-floating species is identified by its oblong or oval cells.

47b Cells without evident individual sheaths; mucilage not in con-

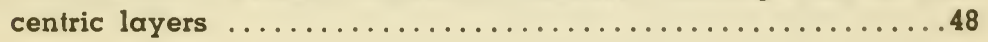

48a Chloroplast cup-shaped, not covering the entire wall; cells all the same size within the colonial mucilage. See Fig. 36...PALMELLA

This genus has shapeless lumps of attached mucilage, sometimes large enough to be seen easily with the unaided eye. The oval cells scattered throughout the mucilage may have individual sheaths. Like Gloeocystis (which also has cup-shaped chloroplasts, Fig. 41) other small, oval cells may be mistaken for Prlmella and vice versa. 
48b Chloroplast covering almost the entire wall; cells variable in size within the colonial mucilage. Fig. $42 \ldots \ldots \ldots$ CHLOROCOCCUM

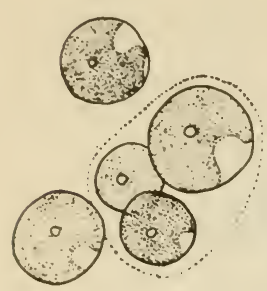

Figure 42

Fig. 42. Chlorococcum humicola (Naeg.) Rab. Cells occasionally are seen to be inclosed in a mucilaginous sheath.

Although this plant occurs on soil it reproduces by swimming reproductive cells (zoospores). Another species, Chlorococcum infusionum (Schrank) Menegh. is aquatic and is differentiated from $C$. humicola by the fact that its cells are all uniform in size and shape. Old, wet bones, and rocks under dripping water are favorable places for both species. Unless it is Pleurococcus (Protococcus), Fig. 66, Chlorococcum humicola is probably the most widely distributed algal species in the world.

49a (39)-Colony fusiform, definite in shape. See Fig. $38 \ldots \ldots \ldots \ldots$ ELAKATOTHRIX

49b Colony not fusiform, but cubical, globular quadrate, or irregular

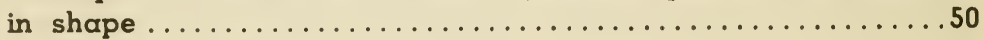

$50 a$ Colony regularly spherical, oval, or a rectangular plate.....61

$50 \mathrm{~b}$ Colony irregular or some other shape (but young stages of Tetraspora, (Fig. 35), may be somewhat spherical)...........5l

5la Colony of 4 cells in one plane interconnected by strands, the cells bearing a scale-like fragment of mother-cell wall. Fig. $43 \ldots . .$. CORONASTRUM

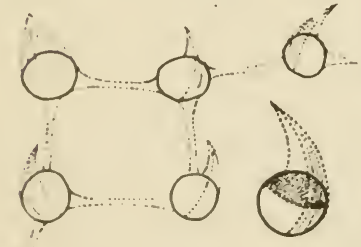

Fig. 43. Coronastrum aestivale Thompson. (Redrawn from Thompson.)

This is a very rare alga and the only one of three species in the genus which has been reported from America. The arrangement of the cells and their distinctive wing-like scale make it easy of identification.

Figure 43 
$52 a$ Colony cubical, consisting of 4 cells at the corners of a hollow cube built of gelatinous strands. Fig. 44......PECTODICTYON

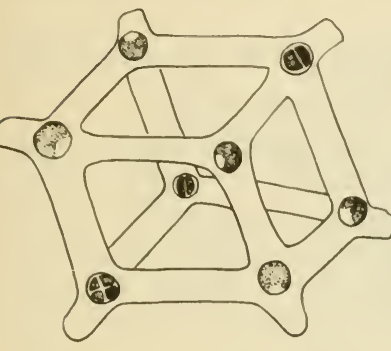

Figure 44

Fig. 44. Pectodictyon cubicum Taft. (Redrawn from Taft.)

There is only one species known for this genus and it has been found but once since it was originally described by Taft from Ohio. It is to be expected in oper water plankton.

52b Colony formed otherwise.

$53 \alpha$ Cells arranged in a linear series within gelatinous tubes (often branched). Fig. $45 \ldots \ldots \ldots \ldots \ldots \ldots \ldots$. PALMODICTYON

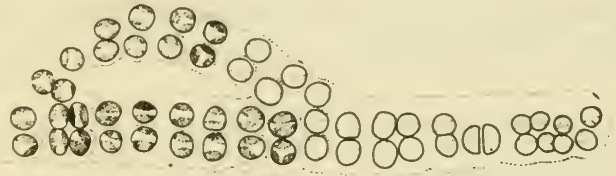

Figure 45

Fig. 45. Palmodictyon viride Kuetzing.

This species and Palmodictyon varium (Naeg.) Lemm. are fairly common in mixtures of algae from the shallow water of ponds and swamps. The former has cells inclosed in individual sheaths, whereas the latter is without cellular sheaths. Some strands of colonial mucilage may be simple, others irregularly branched and sometimes anastomosing.

53b Cells arranged otherwise.

54a Cells cylindrical or elongate-ellipsoid. 
55a Chloroplast axial with one to several pyrenoids. Fig. 46

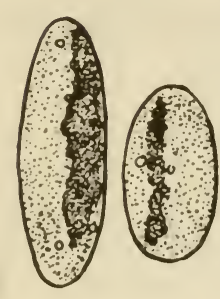

Figure 46

Fig. 46. Mesotaenium Greyii Turner (forma), showing variation in cell shape.

These oval or oblong cells have an axial, platelike chloroplast and a wall that is all in one piece (Saccoderm desmids). Although some of the 5 or 6 species occurring in the country are free-floating, others (Mesotaenium macrococcum (Kuetz.) Roy and Biss., e.g.) usually occur among mosses and in various swamp situations. In high mountain seeps they may occur as gelatinous masses on rocks.

55b Chloroplast a parietal plate, without a pyrenoid. See Fig. 39.... COCCOMYXA

56a Colony forming stringy, intestiniform masses, sometimes perforated skeins. See Fig. $35 a \ldots \ldots \ldots \ldots \ldots \ldots$. . . . . .

56b Colony shaped otherwise

57a Colony a few (2-4) oval cells inclosed in an irregularly shaped, layered, gelatinous sheath. Fig. $47 \ldots \ldots \ldots \ldots$ DACTYLOTHECE

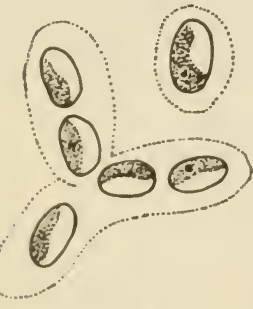

Figure 47
Fig. 47. Dactylothece sp.

Cells in this genus are shaped as in Mesotaenium (Fig. 46) but they are much smaller (not more than $3 \mu$ in diameter) and have a laminate, parietal chloroplast. The cells are inclosed in $\mathrm{mu}$ cilage and form thin expanded masses on moist rocks. D. confluens (Kuetz.) Hansg. is the only species reported from North America. 
57b Colony composed of round or oval cells, gelatinous sheath not

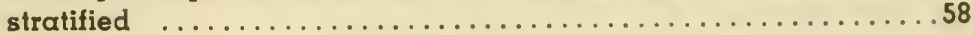

58a Semicircular fragments of old mother-cells partly inclosing daughter cells or lying scattered about in the mucilage. Fig. $48 \ldots \ldots$.

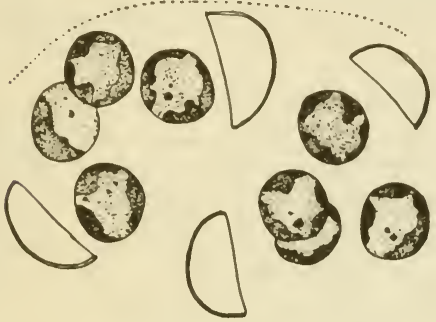

Figure 48
Fig. 48. Schizochlamys gelatinosa $\AA$. Braun.

At times the free-floating gelatinous masses of this plant may be of macroscopic size and they $m a y$ be scooped from the surface of the water by hand. More frequently the growths are less extensive and small aggregates of cells occur intermingled with cell walls help to identify this plant, and under favorable optical conditions the tuft of fine, gelatinous pseudocilia may be seen.

58b Fragments of old mother-cell walls not apparent............59

59a Colonies sac-like or irregularly globose; cells arranged in 4's. See Fig. $35 b$ TETRASPORA

$59 \mathrm{~b}$ Colonies shaped otherwise; cells not arranged in 4 's........60

$60 \alpha$ Cells ovoid, compactly arranged in semi-opaque mucilage which is often brown or yellow and obscures the cells; colonies frequently compounded by interconnecting strands of tough mucilage between clusters of cells. Fig. 49........... BOTRYOCOCCUS

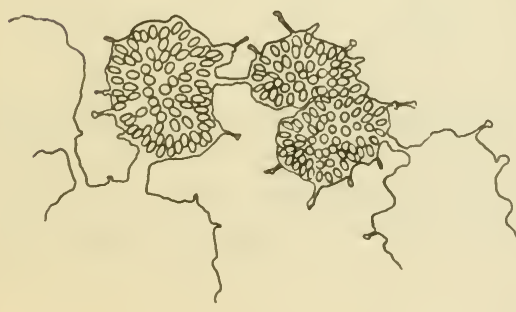

Figure 49

Fig. 49. Botryococcus Braunii Kuetz., showing an expression in which a colonial complex is formed by interconnecting strands of tough mucilage. Colonies frequently appear solitary and as a yellowish-brown lump in which individual cells can scarcely be seen, if at all. The color of the colony lies mostly in the mucilage. This species often forms "blooms" especially in hard water lakes. 
$60 \mathrm{~b}$ Cells round or oval, not arranged in semi-opaque mucilage. See

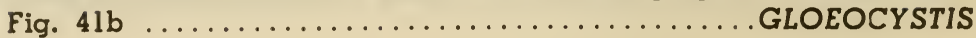

6la (50) Cells incised or constricted in the mid-region to form 'semicells', the cells often interconnected by fine gelatinous strands. Fig. 50 COSMOCLADIUM

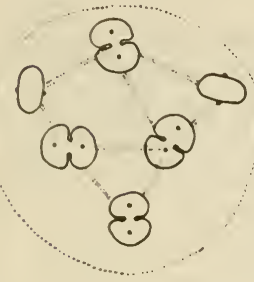

Figure 50
Fig. 50. Cosmocladium tuberculatum Presc.

This species has every appearance of a tiny Cosmarium-like desmid (Fig. 113) in which the cells are enveloped in a colorless, gelatinous sheath. There are but few species in the genus, occurring with other desmids in soft water or acid bogs. Under favorable optical conditions the fine intercellular connecting strands of mucilage can be determined.

61b Cells not constricted to form 'semi-cells'...

$62 \alpha$ Chloroplast star-shaped, the radiating processes with their outer ends flattened against the wall. Fig. $51 \ldots \ldots$. ASTEROCOCCUS

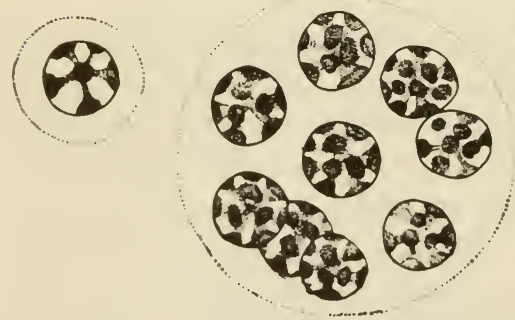

Figure 51

Fig. 51. Asterococcus superbus (Cienk.) Scherf.

This species and $A$. limneticus G. M. Smith are the only ones known to occur in North America. A. superbus may occur singly or in colonies of 2 or 4 cells and shows the star-shaped chloroplast more clearly than does the former which has smaller cells, 8 to 12 , rarely 16 in number within a common envelope. $A$. limneticus, as the name suggests, is found in open water plankton.

62b Chloroplast not star-shaped .63 
63a Cells arranged in groups of 4's at the ends of branching mucilaginous strands (focus carefully into the colony). See Fig. $52 \ldots 64$

63b Cells not arranged at the ends of branching strands........65

64a Cells appearing both reniform (sausage-shaped) and ovoid in the same colony. Fig. $52 \ldots \ldots \ldots \ldots \ldots \ldots$ DIMORPHOCOCCUS

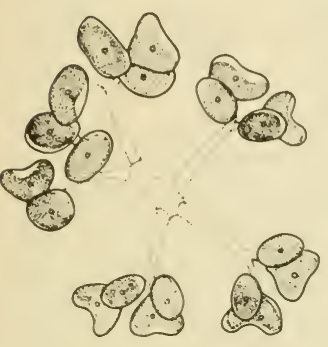

Figure 52

Fig. 52. Dimorphococcus lunatus $\AA$. Braun.

In this plant the cells are in clusters of 4,2 of which when seen in 'top' view appear oval, whereas the others, seen from the side, appear bean-shaped or somewhat crescent-shaped, hence the species name. Dimorphococcus lunatus is often abundant in soft water lakes, whereas the other species known from this country, D. cordatus Wolle, is less frequently found. Both species may occur in open water plankton or in the tychoplankton near shore. A character that is helpful in identification is a negative one, the absence of a conspicuous gelatinous sheath inclosing the colony.

64b Cells spherical or broadly oval, all the same shape within the colony. Fig. 53

DICTYOSPHAERIUM

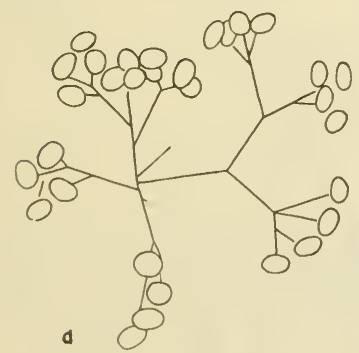

Figure 53

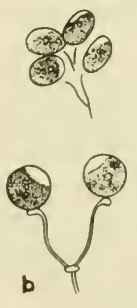

Fig. 53. Dictyosphaerium pulchellum Wood. a, Habit of colony; $b$, Individual cells at ends of radiating strands.

Cells are in clusters of 4 , as in Dimorphococcus (Fig. 52) but all the same shape, round or oval, smaller in size and often more numerous in the colony which is invested by a colonial mucilage. The radiating, branched thread-

like strands are the remains of the old mother-cell wall which has broken down to release daughter-cells.

$65 \alpha$ Cells globular

65b Cells other shapes, ovoid, fusiform, crescent-shaped, or beanshaped 
66a Cells with distinct sheaths; cells inclosed in layered colonial mucilage. See Fig. $41 \ldots \ldots \ldots \ldots \ldots \ldots \ldots \ldots$. GLOEOCYSTIS

66b Cells without distinct sheaths; colonial mucilage not layered

67a Chloroplast cup-shaped with a conspicuous pyrenoid (a doughnutshaped, starch-storing body, usually shiny); colony often including clusters of smaller daughter cells. Fig. 54 ... SPHAEROCYSTIS
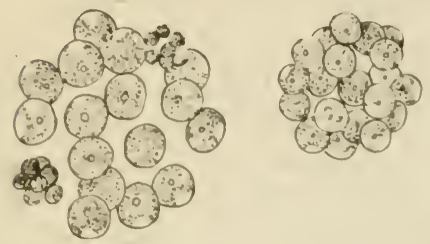

Figure 54

Fig. 54. Sphaerocystis Schroeteri Chod.

This plant, of which there is only 1 species in North American records, should be compared with Planktosphaeria (Fig. 55). There is 1, cup-shaped choroplast, and the colony almost invariably shows clusters of small cells formed by the division of the parent cell into 4 or 8 daughter-cells. There is a gelatinous sheath but the individual cells do not show the lamellated envelope of Gloeocystis, a genus which may be confused with Sphaerocystis. Young cells of Planktosphaeria may have a cup-shaped chloroplast.

67b Chloroplasts several polygonal plates, each with a pyrenoid (chloroplast single when cells are young); colony not containing clusters of daughter-cells. Fig. $55 \ldots \ldots \ldots \ldots \ldots$. PLANKTOSPHAERIA

Fig. 55. Planktosphaeria gelatinosa G. M. Smith.

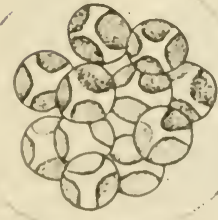

Figure 55

This plant, only one species known, occurs mostly in the tychoplankton (shallow water plankton among other algae) but may appear also in the open water plankton (euplankton). Unless care is used it is easy to confuse this plant with Gloeocystis (Fig. 41) or Sphaerocystis (Fig. 54), or other small, green spherical cells. When mature the cells are recognizable by their angular, 5-sided chloroplasts, each of which contains a pyrenoid. The colonial sheath is often very thin and difficult of determination.

$68 \alpha$ (65) Cells lunate or sickle-shaped, tapering and pointed at the

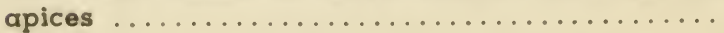

68b Cells bean-shaped, oval or spindle-shaped, the apices sometimes tapered but rounded or blunt.....................70 
69a Cells decidedly curved with the 2 poles nearly touching one another, arranged in scattered groups of 4 with convex walls apposed. Fig. 56

KIRCHNERIELLA

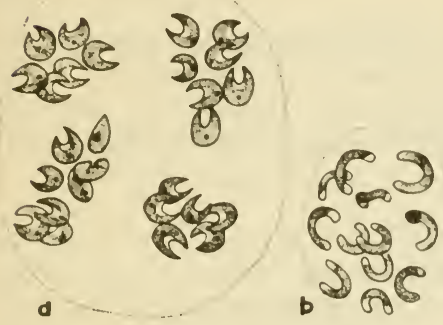

Figure 56

Fig. 56 a, Kirchneriella lunaris (Kirch.) Moebius. b, K. obesa var. major (Ber.) G. M. Smith.

The crescent-shaped or arcuate cells of this genus are inclosed in a (sometimes indistinct) mucilage and are usually found in the open water plankton. There are about 5 species recognized in the United States, showing different degrees of curvature and variations in stoutness. The cells are mostly so sharply curved that their apices nearly touch, whereas in Selenastrum (Fig. 67) the cells are symmetrically crescent-shaped. They do not occur in gelatinous envelopes whereas Kirchneriella is characterized by the presence of a sheath.

69b Cells symmetrically crescent-shaped, in groups of 4,2 of which face one another. Fig. $57 \ldots \ldots \ldots \ldots \ldots \ldots$ TETRALLANTOS

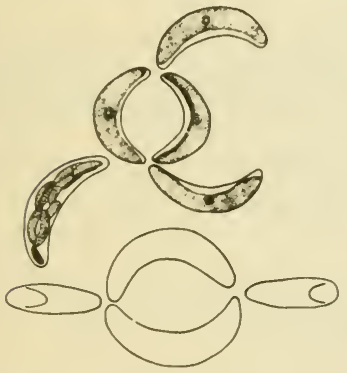

Figure 57

Fig. 57. Tetrallantos Lagerheimii Teiling.

This rare species (the only one in the genus) is widely distributed. The characteristic arrangement of the cells is determined at the time that they are formed in groups of 4 within the mother-cell. After the mother-cell wall breaks down to release the daughter-cells fragments of the wall may persist as interconnecting or radiating threads within the colonial mucilage which is often very thin and difficult of determination.

$70 \propto$ Cells fusiform or spindle-shaped................... 72

$70 \mathrm{~b}$ Cells ovate, bean-shaped, or oblong.................. 71 7 la Cells oval, somewhat irregularly arranged in 4's, forming a flat plate. Fig. $58 \ldots \ldots \ldots \ldots \ldots \ldots \ldots \ldots \ldots \ldots \ldots \ldots \ldots \ldots \ldots \ldots \ldots \ldots \ldots$

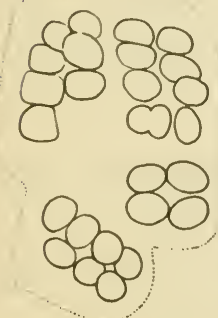

(3) 1020 (3)군 3 (2)

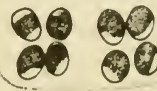

Figure 58
Fig. 58. Dispora crucigenioides Printz.

Only 1 species in the United States, and apparently rare. The cells are in rather irregular rectilinear series and usually show a quartet arrangement within a flat gelatinous sheath. It should be compared with Crucigenia (Fig. 72), especially $C$. irregularis in which the cells are more definitely arranged in 4's. 
$71 \mathrm{~b}$ Cells bean-shaped or oblong, reproducing by autospores which are retained within the enlarged mother-cell wall (the wall may gelatinize and appear as a mucilaginous sheath). Fig. 59.

NEPHROCYTIUM

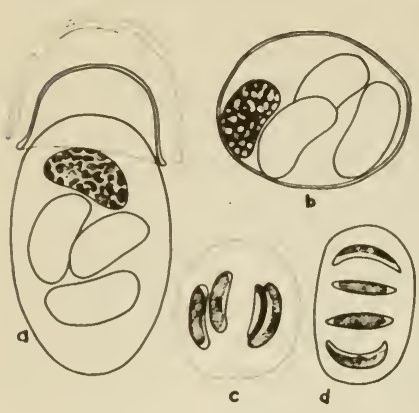

Figure 59

Fig. 59 a, Nephrocytium ecdysiscepanum W. West; $\mathrm{b}, N$. obesum W. \& G. S. West; c, $N$. limneticum (G. M. Smith) G. M. Smith; d, N. lunatum W. West.

Most of the five species of this genus which occur in the United States have reniform or bean-shaped cells, often with one convex wall and one flattened or less convex than the other. They occur in mixtures of algae in the tychoplankton but two species of the genus, $N$. Agardhianum Naeg. and $N$. limneticum G. M. Smith are usually found in the euplankton. The former has elongate, almost vermiform cells which are sometimes curved or spirally twisted.

72a Cells in linear pairs, 1 or several pairs within a common mucilaginous investment (cells with long axes approximately parallel, sometimes solitary). See Fig. $38 \ldots \ldots \ldots \ldots \ldots \ldots$ ELAKATOTHRIX

72b Cells arranged in parallel bundles, reproducing by autospores (daughter colonies forming within the mother-cell). Fig. $60 \ldots$. .......................................

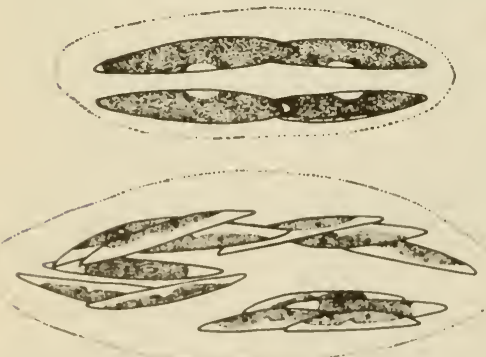

Figure 60
Fig. 60. Quadrigula Chodati (Tanner-Fullman) G. M. Smith.

There are 3 species found in the euplankton of lakes, all of which have elongate,fusiform or 'cigar'-shaped cells. The species illustrated has cells with bluntly rounded poles whereas the other two have pointed apices. The cells occur in rather compact bundles of 4, all lying parallel in the colonial envelope.

$73 \alpha$ (38) Cells (or some of them in the colony) bearing long, gelatinous bristles or scales, or hairs.......................

73b Cells without bristles but some with spines shorter or longer than

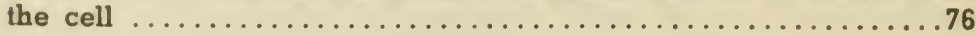


74a Cells arranged in a quadrate colony of 4 cells interconnected by strands, each cell bearing a scale-like fragment of mother-cell wall. See Fig. $43 \ldots \ldots \ldots \ldots \ldots \ldots \ldots \ldots \ldots \ldots \ldots$ CORONASTRUM

74b Colony formed otherwise

75a Cells forming an attached, compact cluster within the mother-cell wall which bears a branched hair that has no sheath. Fig. 61 . DICRANOCHAETE

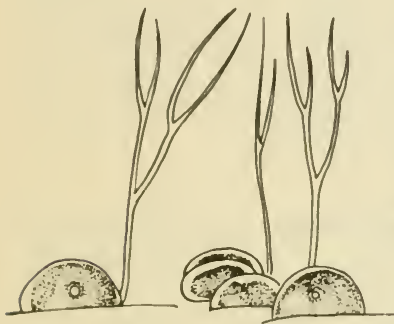

Figure 61

\section{Fig. 61. Dicranochaete reniformis Heiron.}

Although this curious plant usuilly occurs as single cells, the individuals inay be clustered as a result of recent cell division. It grows on filarnentous algae and other submerged aquatic plants and apparently is very rare. The unique branched seta which is produced from the lower side of the cell makes identifications certain.

75b Cells loosely arranged side by side in a cluster, each bearing an unbranched hair with a basal sheath. Fig. 62 .

\section{CHAETOSPHAERIDIUM}

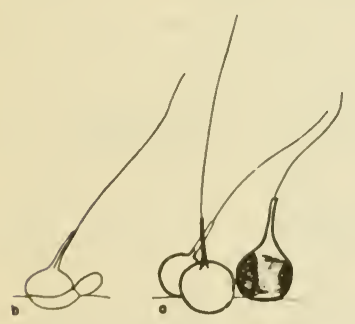

Figure 62

Fig. 62. Chaetosphaeridium globosum (Nordst.) Klebahn. a, group of cells; $\mathrm{b}$, one cell showing tube-like utricle which may extend from one cell to another and so form a sort of colony.

This globular, hair-bearing cell occurs either singly or in aggregations of 2 to 8 individuals on larger algae, on Utricularia or on other aquatic plants. This genus and Dicranochaete (Fig. 61) are anomalous members of a family of filamentous algae. Their inclusion in the Coleochaetaceae is based upon the type of seta (a bristle with a sheathed base) which they have in common.

76a (73) Cells attached at the ends of branching gelatinous stalks, epizoic on microcrustaceans.....................77

76b Cells not at the ends of branching gelatinous strands; not epizoic.78 
77a Cells ellipsoid or somewhat fusiform; chloroplast 1 or 2 longitudinal lateral bands. Fig. $63 \ldots \ldots \ldots \ldots \ldots \ldots$ CHLORANGIUM

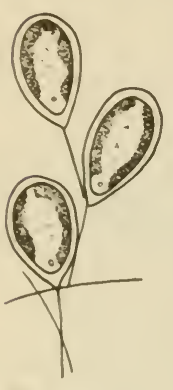

Figure 63

Fig. 63. Chlorangium stentorinum (Ehr.) Stein.

This organism becomes attached, anterior end down, to small crustaceans and other microscopic animals by means of a gelatinous stalk. Although a swimming cell, the flagella are thrown off and the organism continues to divide, the stalk becoming branched as new individuals arise so that a colony results. Some small animals such as Cyclops may go swimming about with veritable plumes of the green cells growing on their antennae. The cells have 2 elongate, parietal chloroplasts. Compare Chlorangium with Colacium (Fig. 64).

77b Cells ovate to oblong or ovoid; chloroplasts numerous ovoid discs.

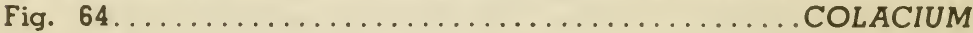
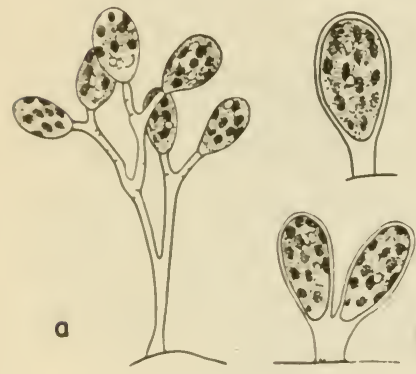

Figure 64

Fig. $64 a$, Colacium arbuscula Stein; b, C. vesiculosum Ehr.

Microscopic animals, especially crustaceans, may appear green because of the large numbers of Colacium individuals attached to them, either singly or in plumelike clusters. Like Chlorangium (Fig. 63) this organism is a motile green cell which, however, has numerous Euglena-like chloroplasts (Fig. 8) and a conspicuous red b pigment-spoi. The rather specific association of the algal cells with the animal host incites speculation as to how this relationship is maintained.

78a (76) Cells ellipsoid or spindle-shaped, attached end to end forming loose branching chains. Fig. $65 \ldots \ldots \ldots$ DACTYLOCOCCUS

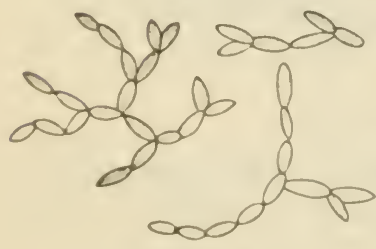

Figure 65

Fig. 65. Dactylococcus infusionum Naeg. (Redrawn from Smith.)

This anomalous genus is known from soil collections of algae. The characteristic chainlike arrangement of the cells develops as the cells are cultivated whereas they probably are solitary in nature.

78b Cells not arranged in branching chains 
79a Cells globose or flattened on some sides from mutual compression; forming green films on moist substrates. Fig. $66 \ldots \ldots \ldots$

PROTOCOCCUS

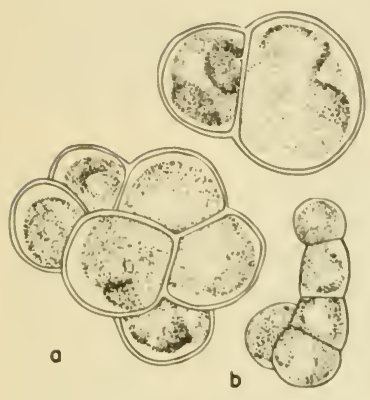

Figure 66

Fig. 66. Protococcus viridis Ag. a, clump of cells; b, filamentous tendency in cell arrangement.

This plant, also known the world over as Pleurococcus vulgaris Menegh., forms the familiar green film on the moist side of trees, rocks, wet boards, etc. Essentially unicellular, it forms clumps from repeated cell division and the occasional tendency to form filaments has led students of the algae to classify it in the filamentous order, Ulotrichales, and to consider it as having been reduced to its present simple morphological condition. It reproduces only by cell division and is easily distributed by wind, water, and insects so that it appears throughout the world almost everywhere that subaerial life can exist.

79b Cells differently shaped, not producing films on aerial substrates .80

$80 a$ Cells crescent-shaped or sharply acicular (needle-shaped).....81

$80 \mathrm{~b}$ Cells some other shape.......................... 82

81a Cells strongly crescent-shaped, closely clustered but not entangled. Fig. $67 \ldots \ldots \ldots \ldots \ldots \ldots \ldots \ldots \ldots \ldots$. . . . . . . . . . . . . .

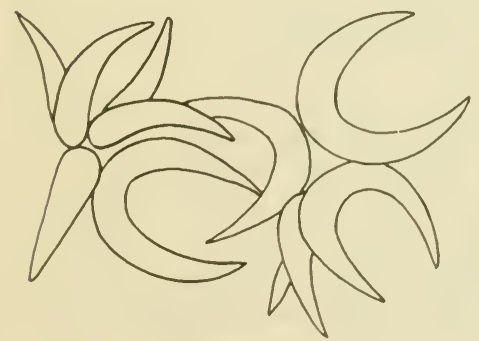

Figure 67

Fig. 67. Selenastrum gracile Reinsch.

These gracefully curved cells occur in clusters of from 4 to 32 , with a tendency to have the convex or 'outer' walls approximated. The curvature of the 'outer' and 'inner' walls of the crescent are more nearly the same than in the somewhat similarly shxped cells of Kirchneriella (Fig. 56), a genus which has cells irregularly arranged within a gelatinous envelope. Four species are commonly found in this country, mostly differentiated by size and degree of curvature. Mixtures of algae from shallow water situations often include Selenastrum but they may be found also in the euplankton. 
$81 \mathrm{~b}$ Cells straight or only slightly crescent-shaped, loosely entangled about one another (frequently solitary rather than colonial). Fig. 68

ANKISTRODESMUS

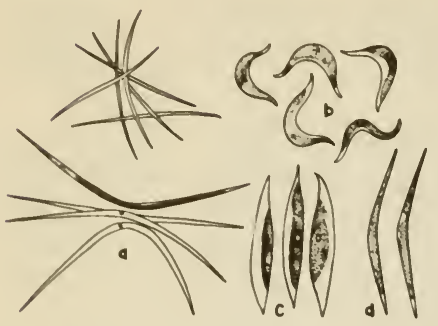

Figure 68

Fig. 68a. Ankistrodesmus falcatus (Cor. da) Ralfs; b. A. convolutus Corda; c, A. Braunii (Naeg.) Brunn.; d, A. fractus (W. \& G. S. West) Brunn.

Although there are 5 or 6 species of this genus common in the United States, A. falcatus (Corda) Ralfs is probably the one most frequently collected. It occurs as solitary or loosely clustered needles or slightly fusiform-shaped cells intermingled with other algae, or sometimes forming almost pure growths in artificial pools or in laboratory aquaria. One species, $A$. spiralis (Turn.) Lemm., has needle-shaped cells spirally twisted about one another to form bundles.

$82 \alpha$ (80) Cells attached either along their side or end walls to form definite patterns, nets, plates, triangular clusters, or short rows. .83 end only in juxtaposition. See Fig. 57......... TETRALLANTOS

$82 \mathrm{~b}$ Cells attached otherwise, if adjoined by lateral walls then not forming definite patterns.......................98

$83 \alpha$ Cells cylindrical, one cell attached by 2 others at the end walls repeatedly to form a network. Fig. 69........HYDRODICTYON

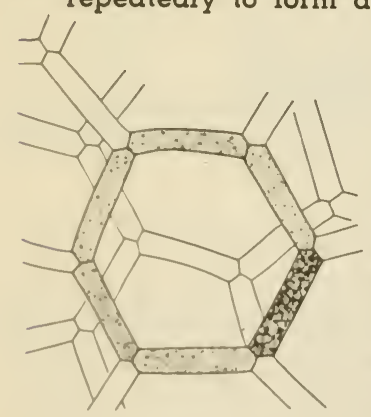

Figure 69

Fig. 69. Hydrodictyon reticulatum (L.) Lagerheim.

This is the familiar "water-net" which often grows in such dense mats in lakes, small ponds and irrigation ditches as to become a troublesome weed. This unique alga is able to reproduce very rapidly because each cell of the net in turn produces a new cylindrical net of small cells within it, which upon escape enlarge enormously, each cell again producing a net. The nets are of macroscopic size and there is a report of one being found more than 2 feet in length. It is thought that the first written records referring to a specific alga is of Hydrodictyon in ancient Chinese literature.

$83 \mathrm{~b}$ Cells some other shape, not attached to form $\alpha$ network.....84

$84 a$ Cells arranged to form flat, circular or rectangular plates. (Fig. 70) 
$85 a$ Cells forming circular plates (sometimes irregularly subcircular), the marginal cells sometimes different in shape from those within. Fig. 70

PEDIASTRUM
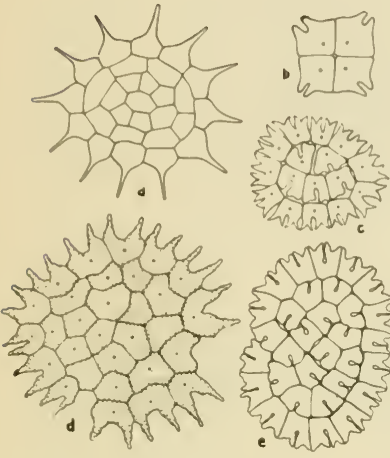

Figure 70
Fig. 70 a, Pediastrum simplex (Meyen) Lemm.; b, P. tetras (Ehr.) Ralfs; c, $P$. biradiatum var. emarginatum fa. convexum Pres.; d. P. Boryanum (Turp.) Menegh.; e, $P$. obtusum Lucks.

Although there are many species of this genus all may be identified by the platelike arrangement of cells. The plate may be continuous with internal cells different in shape from those at the periphery, or there may be interstices with all cells in the colony about the same shape. One, P. tetras (Ehr.) Ralfs, forms plates of but 4 cells. Rarely a 2-celled colony may appear, in which case it might be mistaken for Euastropsis (Fig. 33).

$85 \mathrm{~b}$ Cells not arranged to form circular plates 86

$86 a$ Cells triangular or ovoid, forming quadrangular plates, bearing one or more spines. Fig. $71 \ldots \ldots \ldots \ldots \ldots$. . . . .

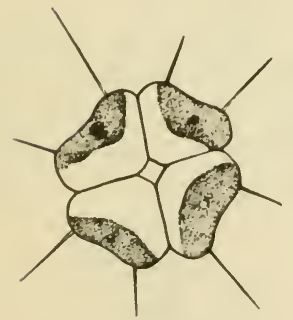

Figure 71

Fig. 71. Tetrastrum heterocanthum (Nordst.) Chod.

There are probably only three species of this genus reported from the United States. They occur in the euplankton and are readily identified by their arrangement in flat plates of four, the cells bearing 1 to 4 spines on the outer free walls.

86b Cells rectangular or trapezoidal or if oval, without spines... . . 87 
87a Cells rectangular, oval, or trapezoidal, the outer walls entire (not incised); arranged to form quadrate plates in 4's or in multiples of 4. Fig. 72 .

CRUCIGENIA

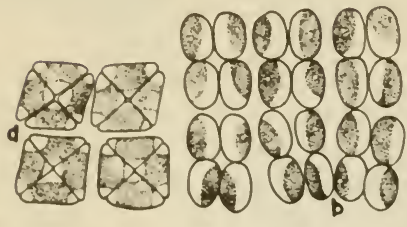

Figure 72

Fig. 72 a, Crucigenia tetrapedia (Kirch.) W. \& G. S. West; b, C. rectangularis (A. Braun) Gay.

These cells (like Tetrastrum, Fig. 71) occur in 4's but usually form multiple colonies of rectangular plates. There are about a dozen species in the United States, differentiated by the shape of the cell which may be oval, triangular or elliptic in outline.

87b Cells trapezoidal, the outer free walls deeply incised, forming oval or somewhat angular plates (only 4 cells present in some colonies).

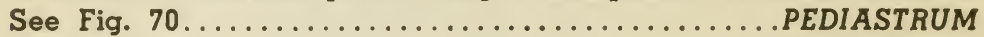

$88 a(84)$ Cell walls with spines........................ 89

88b Cell walls without spines....................... 92

89a Cells ellipsoid, spines numerous, needle-like; cells (usually solitary) arranged side by side because of interlocking spines, indefinite in

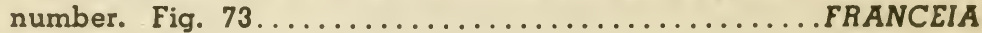

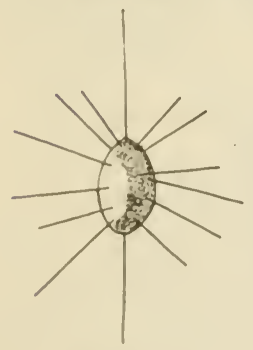

Fig. 73. Franceia Droescheri (Lemm.) G. M. Smith.

This and two other species occur in the euplankton of lakes but rather rarely. The cells are solitary but they may be clustered from the interlocking of the needle-like spines which cover the wall. Lagerheimia (Fig. 118) has a similar shape and needlelike spines that are confined to the poles or to the mid-region of the cell.

Figure 73

89b Cells ovoid or spherical; spines few (1-4), cells definitely arranged and definite in number........................... 90 
90a Cells ovoid, arranged side by side in one or two alternating rows; spines short, mostly arising from the poles of the cells only. Fig. 74.

SCENEDESMUS

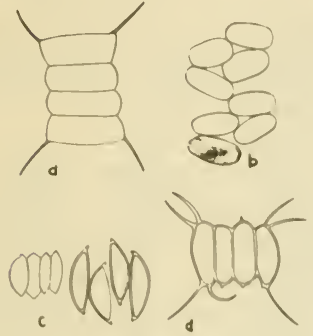

Figure 74

Fig. 74. a, Scenedesmus quadricauda (Turp.) de Breb.; b. S. bijuga var. alternans (Reinsch) Hansg.; c. S. incrassatulus var. mononae G. M. Smith (Redrawn from Tiffany); d, S. opoliensis P. Richter.

There are numerous species of this genus occurring both in the euplankton and the tychoplankton (intermingled, free-floating algae in shallow water near shore). The cells are oval, fusiform, or crescent-shaped according to species, and occur side by side in one series of 4 , or in a double, alternating series of 8 ; rarely a single series of cells will have 8 or 12 cells. Certain species of Scenedesmus invariably appear in laboratory cultures, often coloring the water green. Under unnatural conditions the cells often appear singly rather than in colonies of 4 . Perhaps the most common species is S. quadricauda (Turp.) de Breb in which the two outer cells of the series bear a long curved spine at their poles.

$90 \mathrm{~b}$ Cells spherical, in groups of 4 or in multiples of 4 to form compound colonies, outer walls bearing long, slender spines......91 9la Colony triangular, spines $1-7$. Fig. $75 \ldots \ldots \ldots$ MICRACTINIUM

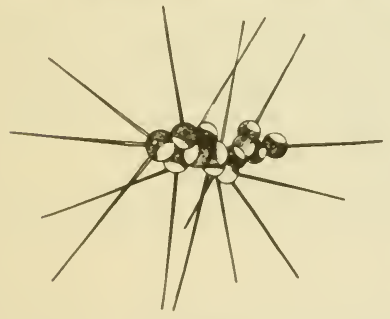

Figure 75
Fig. 75. Micractinium pusillum Fres.

This rare alga occurs in the euplankton, having clusters of 4 round cells arranged in the form of a pyramid. Each cell bears 1 to several long, tapering spines. Another species which is also seldom seen is $M$. quadrisetum (Lemm.) G. M. Smith, having oval or elliptic cells.

9lb Colony pyramidal but with outer wall bearing a single stout spine. Fig. 76 . ERRERELLA

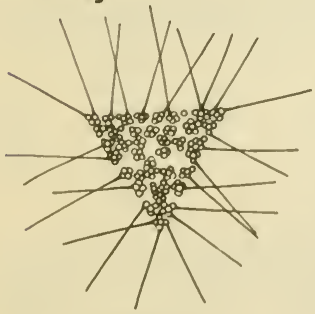

Fig. 76. Errerella bornhemiensis Conrad.

Cells of this plant, of which there is but $\alpha$ single species, are arranged to form a 3-dimension pyramid. It is known only from the euplankton and apparently is very rare.

Figure 76 
92a (88) Cells spherical or polygonal, arranged to form hollow, spherical or many-sided colonies; cells adjoined by interconnecting protuberances of the mucilaginous sheath. Fig. 77....COELASTRUM

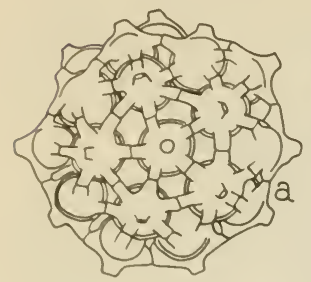

Figure 77

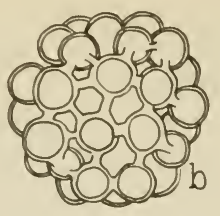

plant are arranged to form hollow colony. Six or seven species are known from this country, differing in the shape of the cell and in the length of the intercon-

necting processes. Common in both euplankton and in the tychoplankton.

92b Cells not forming hollow colonies and not so adjoined........93

93a Cells fusiform, radiating from a common center. Fig. $78 \ldots \ldots$ ACTINASTRUM

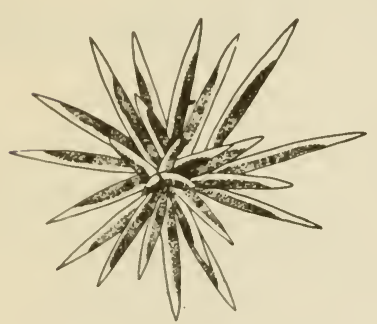

Figure 78
Fig. 78. Actinastrum Hantzschii Lag.

These "cigar"-shaped cells are arranged in radiating colonies. This species is more common in the plankton than is $A$. gracillimum G. M. Smith which has pointed rather than truncate apices.

93b Cells shaped otherwise, not forming a colony of radiating cells. .94

94a Cells ellipsoid to fusiform, adjoined end to end, forming chain-like series. See Fig. $65 \ldots \ldots \ldots \ldots \ldots \ldots \ldots$. . . . . . . .

94b Cells not forming chains

$95 \alpha$ Cells ovoid, ellipsoid or fusiform, adjoined by their lateral wall to form a row of 4 in a single series, or a double series in which the cells are alternating. See Fig. $74 \ldots \ldots \ldots \ldots$. SCENEDESMUS 
95b Cells globular or variously shaped, not attached side by side in

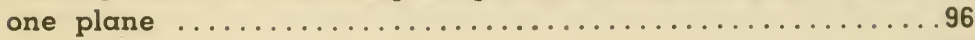

96a Cells fusiform or trapezoidal, attached with their long axes parallel about a common center. Fig. 79..........TETRADESMUS

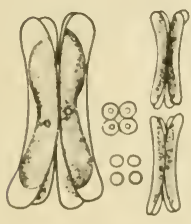

Figure 79

\section{Fig. 79. Tetradesmus Smithii Presc.}

This plant resembles some Scenedesmus species (Fig. 74) but differs in having the cells quadrately arranged rather than in a series in one plane. There are but two species known in this country, both of them from the euplankton of Wisconsin lakes. T. wisconsinense G. M. Smith has trapezoidal cells.

96b Cells some other shape and not attached about a common center.97

97a Cells crescent-shaped, in groups of 4,2 with concave sides toward one another, the other 2 cells in another plane with poles at one end only in juxtaposition. See Fig. $57 \ldots \ldots \ldots$ TETRALLANTOS

97b Cells sickle-shaped, fusiform or crescent-shaped, twisted about one another. See Fig. $68 \ldots \ldots \ldots \ldots \ldots \ldots \ldots$ ANKISTRODESMUS

98a (82) Cells adjoined by gelatinous strands or threads formed from the remains of old mother-cell walls..................99

98b Cells not adjoined by remains of old mother-cell walls.......101

99a Cells spindle-shaped, in clusters of 4-8-16 at the ends of radiating gelatinous stalks. Fig. $80 \ldots \ldots \ldots \ldots \ldots \ldots \ldots$ ACTIDESMIUM

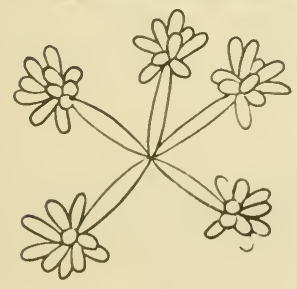

Figure 80
Fig. 80. Actidesmium Hookeri Reinsch.

This rare plant occurs in the tychoplankton of shallow pools. The star-shaped clusters of cells at the ends of radiating (sometimes dichotomously branched) gelatinous stalks render it easy of identification. 
100a Cells globose, in clumps of 4-8, the groups held together by looplike fragments of old mother-cell wall. Fig. $81 \ldots \ldots$ WESTELLA

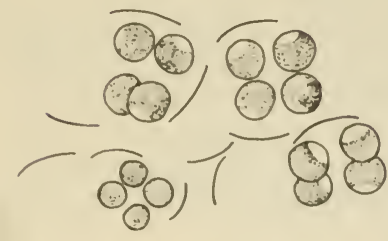

Figure 81

Fig. 81. Westella botryoides (W. West) de Wild.

This plant should be compared with Dictyosphaerium (Fig. 53) which it may resemble superficially at times. Westella has no gelatinous envelope and although there are strands left by the old mothercell wall they do not produce the regular radiate structures as in Dictyosphaerium.

$100 \mathrm{~b}$ Cells appearing oval and bean-shaped in the same colony, in clusters at the ends of radiating, branched strands. See Fig. 52. DIMORPHOCOCCUS

10la (98) Cells pear-shaped, bean-shaped, or somewhat crescentshaped, the outer free wall bearing 2 to 4 stout spines: cells arranged at the ends of radiating, stout, gelatinous strands to form a globular colony. Fig. $82 \ldots \ldots \ldots \ldots \ldots \ldots \ldots$ SORASTRUM

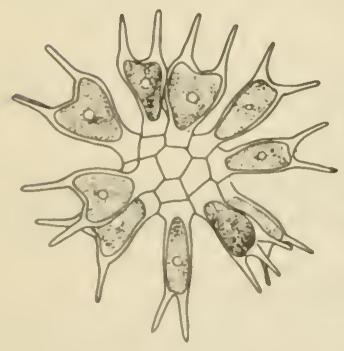

Figure 82

Fig. 82. Sorastrum americanum (Bohlin) Schmidle.

There are only 2 species of this genus reported from the United States, of which S. spinulosum Naeg. is probably the more common in the plankton. This species has relatively stout short spines and the basal pedicel is scarcely developed so that the colony appears as a compact cluster.

101b Cells not so arranged, without spines or with spines different

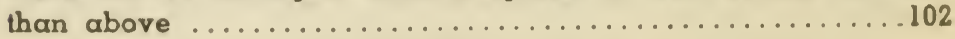


$102 a$ Cells spherical or oval, in 2's and 4's, separated from one another by semi-opaque masses of dark mucilage which form X-shaped bands. Fig. $83 \ldots \ldots \ldots \ldots \ldots \ldots$ GLOEOTAENIUM

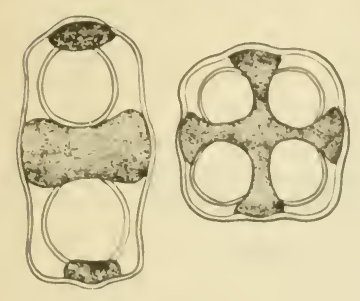

Fig. 83. Gloeotaenium Loitelsbergerianum Hansg.

This unique plant is rare but widely distributed. When it occurs at all it is relatively abundant. Collections from the mixture of algae in shallow water ponds and bogs often yield this species.

Figure 83

102b Cells not separated from one another by masses of dark mucilage

103a Cells bearing long, needle-like spines (colonial only because of entangled spines). Fig. $84 \ldots \ldots \ldots \ldots \ldots \ldots$ GOLENKINIA

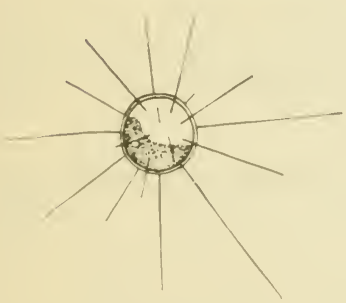

Figure 84

Fig. 84. Golenkinia radiata (Chodat) Wille.

There are but 2 species of this genus reported, both of them common in two samples from the open water of lakes. G. radiata Chod. has spines 2 to 3 times the diameter of the cell in length, whereas $G$. paucispina West \& West has more numerous spines that are about equal to the cell diameter in length.

103b Cells without spines. 104

$104 a$ Cells inclosed by old mother-cell wall 105

104b Cells not inclosed by old mother-cell wall. 106

$105 a$ Cells somewhat bean-shaped or kidney-shaped, or broadly elliptic (old mother-cell wall often appearing as a mucilaginous sheath). See Fig. $59 \ldots \ldots \ldots \ldots \ldots \ldots \ldots \ldots \ldots$. . . . . . . . . . . . . . . 
105b Cells elliptic, lemoz-shaped, or nearly cylindrical, 1 to several generations of mother-cell walls inclosing daughter cells. Fig. 85.

OOCYSTIS

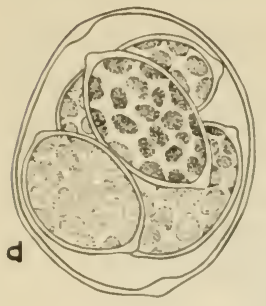

b

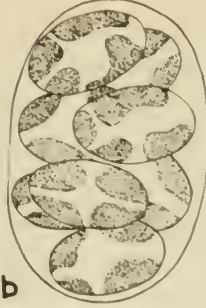

Figure 85

Fig. 85. a, Oocystis Eremosphaeria G. M. Smith; b, O. Borgei Snow.

There are several species of this genus common in both the euplankton and the tychoplankton. The various forms are differentiated by the presence or absence of nodules at the poles and by the number of chloroplasts. Two or 3 generations of cell walls may be inclosed within an original mother-cell wall which enlarges so that it often appears as a gelatinous sheath and is, therefore, misleading as a differentiating genus character.

106a Cells spherical, occurring as evenly distributed clumps within the gelatinous sheaths which sometimes are lacking; chloroplasts several angular plates. See Fig. $55 \ldots \ldots \ldots$. PLANKTOSPHAERIA

106b Cells variously shaped but not distributed in clumps as above; often densely aggregated; chloroplast 1, parietal. . . . . . . . 107

107a Cells spherical or angular from mutual compression when occurring in clumps: subaerial. ..................... 08

107b Cells fusiform or needle-shaped, aquatic. See Fig. 68....... ANKISTRODESMUS

108a Cells spherical, clustered but not adjoined, sometimes solitary. See Fig. 42. CHLOROCOCCUM

108b Cells in dense clumps, forming a film or a layer on moist subaerial substrates; cells spherical or angular from mutual compression. See Fig. $66 \ldots \ldots \ldots \ldots \ldots \ldots \ldots$.............

(PLEUROCOCCUS)

109a (36) Cells crescent-shaped, or sickle-shaped, with sharply pointed or narrowly rounded and tapering apices............ 110

109b Cells some other shape. 
$110 \alpha$ With 2 axial chloroplasts bearing longitudinal ridges, a chlor. plast in either horn of the cell; pyrenoids conspicuous, usually in an axial row. Fig. $86 \ldots \ldots \ldots \ldots \ldots \ldots \ldots$ CLOSTERIUM

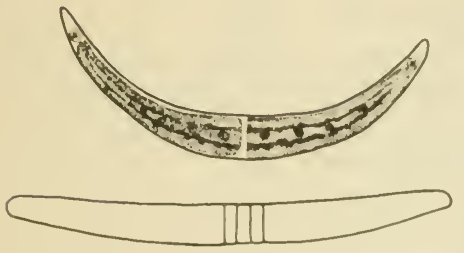

Figure 86

Fig. 86. Closterium spp. Two of the many variations in curvature and cell proportions exhibited in this genus.

This desmid usually has distinctly crescent-shaped cells, but some species are nearly straight, or have the outer margin of the cell bowed and the inner almost straight. A few species have the poles extended to form long, almost straight, needle-like processes which are swollen at the tip. Although this genus does not show the constriction of the cell to form two semi-cells characteristic of most other true desmids, the cell contents are symmetrically divided into 2 portions with the nucleus centrally located. A never-failing characteristic of Closterium is the polar vacuoles containing vibrating granules of gypsum.

$110 \mathrm{~b}$ Cells with 1 chloroplast, or with parietal chloroplasts not arranged

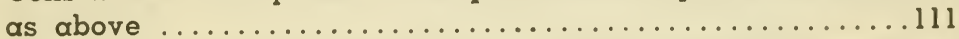

111 a Cells only slightly crescent-shaped, (usually straight or nearly so, and often irregularly curved), with poles drawn out into fine

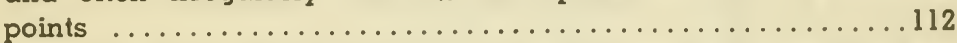

$111 \mathrm{~b}$ Cells definitely crescent-shaped, or with poles not drawn out into

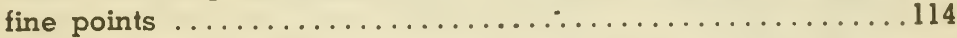

$112 \alpha$ Cells attached by a slender stipe to other algae or to microfauna. Fig. 87

CHARACIUM
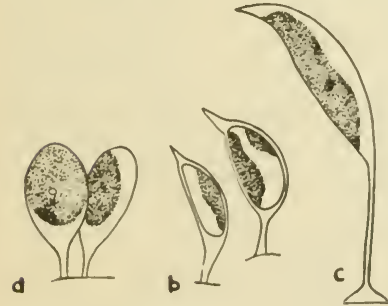

Figure 87

Fig. 87. a, Characium Debaryanum (Reinsch) DeToni; b, C. ornithocephalum A. Braun; C, C. rostratum Reinhard.

There are numerous species in this genus, differentiated by shape of cell and by presence or absence of a stalk. Some are very minute and are easily overlooked, whereas others are larger and grow in associations so as to form conspicuous patches on filaments of algae or on small animals. The genus Characiopsis contains species shaped like some of those of Characium and care should be used in determining the color of the chloroplast and the presence or absence of a pyrenoid in making identification. Characiopsis (Fig. 217) has a yellow pigment predominating and starch tests are negative; is a member of the Chrysophyta.

$112 b$ Cells not attached by $\alpha$ stipe....................113 
$113 \alpha$ Wall at the poles of the cell extended to form slender setae, one of which may be forked; cholorplasts extending the full length of the cell. Fig. $88 \ldots \ldots \ldots \ldots \ldots \ldots \ldots \ldots$. SCHROEDERIA

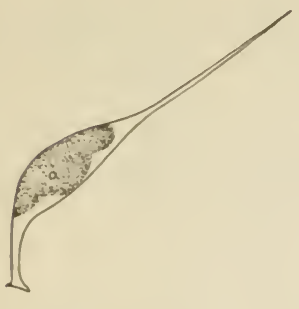

Figure 88

Fig. 88. Schroederia Judayi G. M. Smith.

One of the three species found in the United States, S. setigera (Schrod.) Lemm., is the most common. The cells have a spine at both poles which is undivided, whereas S. ancora G. M. Smith, also fairly common in plankton, has one polar process forked at the tip. In a Michigan pond the former species occurred as practically the only member of the plankton throughout winter months.

$113 \mathrm{~b}$ Tips of the cells narrowed to fine points at least at one end with the poles narrowly rounded, tip not seta-like but narrowly pointed; chloroplast not extending the full length of the cell. Fig. 89...

.OUROCOCCUS

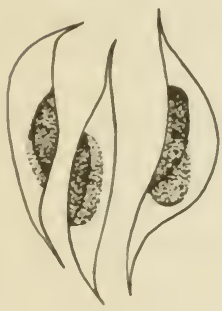

Figure 89

Fig. 89. Ourococcus bicaudatus Grob. (Redrawn from Smith.)

This rare plant might be confused easily with Ankistrodesmus spp. (Fig. 68) but the cells are usually stouter. It is closely related to Elakatothrix (Fig. 38) in the Order Tetrasporales because the cells retain the ability to divide vegetatively to form new individuals, whereas in the Order Chlorococcales, which concerns cells similar in shape to Ourococcus, the cells cannot undergo division but must form new individuals within the wall of the parent cell.

114a (111) Cells very slender, needle-like or sometimes fusiform (usually in clusters but sometimes solitary), often only slightly. crescentshaped; chloroplast parietal, the outline often discerned with difficulty. See Fig. $68 \ldots \ldots \ldots \ldots \ldots \ldots \ldots$ ANKISTRODESMUS

114b Cells stouter, not needle-like; definitely crescent-shaped, the chloroplast parietal and definite in outline...............115 
119a Plant a much-branched, coenocytic tube (multi-nucleate and without cross walls), growing in leaves of Araceae (Indian Turnip). Fig. $92 \ldots \ldots \ldots \ldots \ldots \ldots \ldots \ldots \ldots \ldots$. . . . . . .
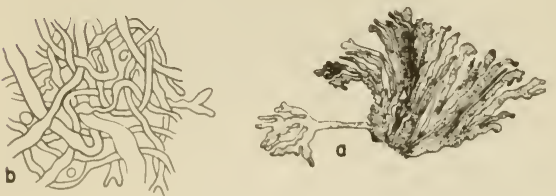

Figure 92

Fig. 92. Phyllosiphon Arisari

Kuhn. $a$, portion of thallus showing tangled threads; $b$, habit of thallus in tissue of host (redrawn from Just).

This branched, tubular plant is non-cellular; forms green patches in the leaves of higher plants which become discolored. It may be more widely distributed than appears to be the case at present, but so far it is known only from northern and eastern sections of the United States.

$119 b$ Plant not a branched coenocyte.

120a An irregularly shaped, flask-like cell in the tissues of Ambrosia (ragweed), and other plants. Fig. 93......RHODOCHYTRIUM

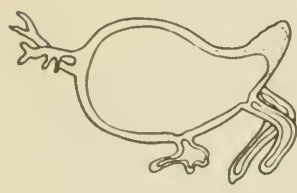

Figure 93

Fig. 93. Rhodochytrium spilanthidis Lag.

This curiously shaped, unicellular parasite occurs on a greater variety of hosts than Phyllosiphon (Fig. 92), but seems to be most frequent in ragweed. It is quickly identified by the red color and the large number of strach grain that are usually present.

$120 \mathrm{~b}$ An irregularly oval, thick-walled cell in the tissues of Lemna (duckweed). Fig. $94 \ldots \ldots \ldots \ldots \ldots \ldots$. CHLOROCHYTRIUM

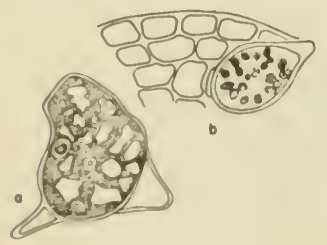

Figure 94

Fig. 94. Chlorochytrium Lemnae Cohn. $\alpha$, showing net-like chloroplast (redrawn from Bristol-Roach); b, cell in host tisue.

The duckweed, Lemna trisulca, is the most common host for this endophytic alga. Old plants of Lemna as they become colorless in age, usually reveal minute green spots caused by Chlorochytrium.

There are probably three other species in the United States, differentiated by cell size and thickness of the wall which is usually much lamellated. 
12la (117) Cells attached, either sessile or on a stalk.........122

$121 \mathrm{~b}$ Cells free-floating or forming a film on moist earth.......126

$122 \alpha$ Cells bearing a seta or hair...........................

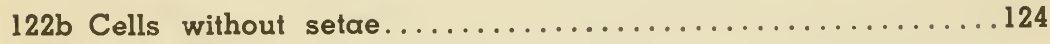

123a Setae simple (unbranched). See Fig. 62..CHAETOSPHAERIDIUM

123b Setae branched. See Fig. $61 \ldots \ldots \ldots \ldots \ldots$ DICRANOCHAETE

$124 a$ Cells on $\alpha$ slender stalk or with the basal portions of the cell narrowed to form a stalk........................ 125

124b Cells globular, attached by a broad, short stalk. Fig. $95 \ldots \ldots$ MALLEOCHLORIS

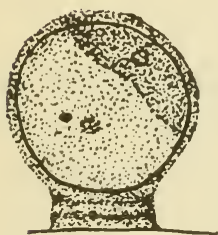

Figure 95

Fig. 95. Malleochloris sessilis Pascher (redrawn from Pascher).

This rare plant is to be sought on filamentous algae such as members of the Cladophoraceae. The sheath that incloses the cell is often reddish. Reproduction (similar to other Tetrasporales) is by swimming spores and by isogametes.

125a Cells globular, with chloroplast lying along the outer free wall; growing on Anabaena or Coelosphaerium. Fig. 96.

STYLOSPHAERIDIUM
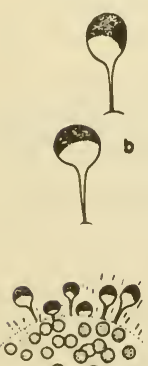

00 a

Figure 96

Fig. 96. Stylosphaeridium stipitatum (Bach.) Geit. \& Gimesi, $a$, habit of cells in colonial mucilage of Coelosphaerium; $b$, single cells showing apical position of chloroplast.

This curious epiphyte is found in abundance when it occurs at all as minute "hat pins" in the mucilage of colonial blue-green algae such as Coelosphaerium. (Fig. 319.) 
$125 \mathrm{~b}$ Cells elongate-ovoid, or fusiform, or if globular, with a chloroplast parietal along the lateral walls. See Fig. 87. CHARACIUM (Compare with Characiopsis, Fig. 217, a genus similar in shape, belonging to the Chrysophyta in which the chromatophores are yellowish-green.)

126a (121) Cells elongate-fusiform, or rod-shaped, crescent-shaped, slightly curved, or straight; several to many times longer than their diameter .............................. 127

126b Cells oval, circular (or nearly so), pyramidal, trapezoidal, or starshaped, isodiametrically angular; not more than 3 times the diameter in length............................. 146

127a Cells with narrowed apices, sometimes sharply pointed...

128

$127 \mathrm{~b}$ Cells with broadly rounded or truncate apices...........133

128a Chloroplasts 2, axial, one in either horn of a crescent-shaped cell which may be only slightly curved. See Fig. $86 \ldots$... CLOSTERIUM

128b Chloroplasts otherwise

129a Cells decidedly fusiform, one or both poles extended into setae

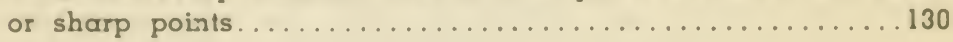

129b Cells not broadly fusiform

130a Cells actually globular but inclosed in a fusiform sheath with longitudinal ridges. Fig. 97

DESMATRACTUM

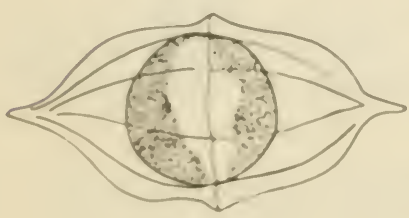

Figure 97

Fig. 97. Desmatractum bipyramidatum (Chod.) Pascher.

This unique species, the only one of the genus in this country, is rather rare but seems to be widely distributed in the plankton of both streams and lakes. The wall is very wide and transparent, forming a sheath-like envelope. 
130b Cells themselves fusiform; without such a sheath

13la Setae formed by a narrowing of the cell to a fine point; chloroplast laminate (plate-like), not extending the full length of the cell. See Fig. $89 . \ldots \ldots \ldots \ldots \ldots \ldots \ldots \ldots \ldots$ OUROCOCCUS

131b Setae formed by a fine spine on the wall, extending from the narrowed tips of the cells. See Fig. $88 \ldots \ldots \ldots \ldots$ SCHROEDERIA

$132 \alpha$ (129) Cells many (20 or more) times longer than wide; the chloroplast with a row of pyrenoids. Fig. $98 \ldots \ldots \ldots$ CLOSTERIOPSIS

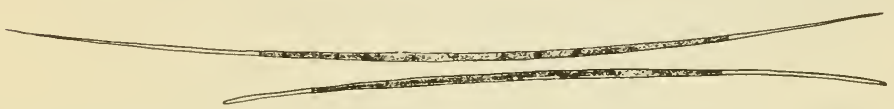

Figure 98

Fig. 98. Closteriopsis longissima Lemm.

There is but one species reported from this country. Although it superficially resembles a Closterium (Fig. 86) it is easily separated on the basis of the single, plate-like chloroplast which may be notched or crenulate along the margin. At times the cells are slightly curved but usually are more nearly straight than any of the species of Closterium.

132b Cells less than 20 times the diameter long: slender needles or narrowly fusiform cells with one pyrenoid sometimes evident. See Fig. $68 \ldots \ldots \ldots \ldots \ldots \ldots \ldots \ldots$ ANKISTRODESMUS

$133 \alpha$ (127) With $\alpha$ notch in the ends of the cell. Fig. $99 \ldots \ldots \ldots \ldots$

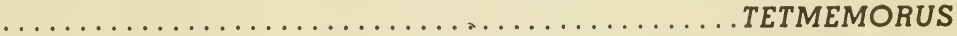

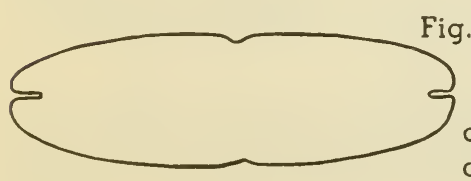

Fig. 99. Tetmemorus laevis (Kuetz.) Ralfs.

Figure 99

This is a genus belonging to the true desmids, having a wall in 2 pieces that adjoin in the midregion. Species that are found in this country seem to be con-

fined to highly acid situations. There are several species reported, some with cylindrical shapes and some with the ends tapering, but always with a prominent polar notch. A placoderm desmid. 
$133 \mathrm{~b}$ Without a notch in the ends of the cell

134a Cells crescent-shaped, with an axial chloroplast bearing ridges in each horn. See Fig. $86 \ldots \ldots \ldots \ldots \ldots \ldots \ldots \ldots$ CLOSTERIUM

134b Cells not crescent-shaped, or with other types of chloroplasts. 135

135a Cells constricted in the midregion to form 2 'semicells' which are mirror images of one another..................... 36

135b Cells not constricted in the midregion to form 'semicells'.... 141

136a Cells furnished with whorls of protuberances which bear one or two spines; poles of the cell forked. Fig. 100 ... TRIPLOCERAS

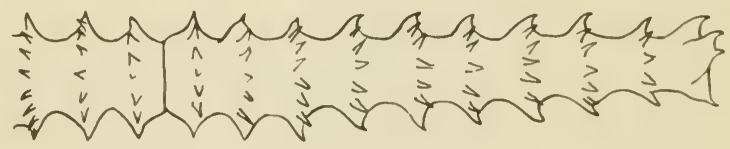

Figure 100

Fig. 100. Triploceras gracile Bailey.

There are apparently only two species of this desmid genus in the United States, easily identified by the whorls of spine-bearing protuberances along the walls. Like a number of other desmid genera this one seems to be conflned to acid water, especially in Sphagnum bogs.

136b Cells not furnished with whorls of spiny protuberances.... . 137

137a Cells 10 or more times longer than broad, usually cylindrical or nearly so, with margins smooth or undulate...........138

137b Cells less than 10 times their diameter in length; cylindric, fusiform, or tumid, usually straight but sometimes slightly curved. . 139 
$138 \alpha$ With a circle of folds or creases at the base of the 'semicell,' with $a$ tooth on each fold. Fig. $101 \ldots \ldots \ldots \ldots \ldots \ldots$. . . . .

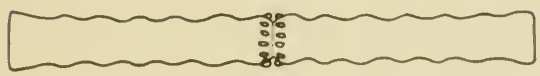

Figure 101

Fig. 101. Docidium undulatum Bailey.

This genus is scarcely to be separated from Pleurotaenium (Fig. 102). In cells that are living the density of the chloroplast makes obscure the characteristic creases in the wall where the two semicells are adjoined. One needs to focus carefully to see these folds which produce teeth-like projections at the very outer margin of the bases of the semicell, especially in individuals which have a granule on the fold. Another species, D. Baculum Breb., less common than the species illustrated, has smooth lateral walls.

138b Without a circle of creases at the base of the 'semicell.' Fig. 102. PLEUROT AENIUM

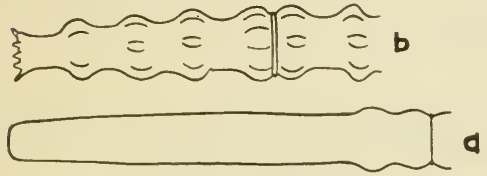

Figure 102

Fig. 102. a, Pleurotaenium trabecula (Ehr.) Naegeli; b, P. nodosum Bailey.

There are more species in this genus than in Docidium (Fig. 101) and they are more widely distributed. Although all of them are elongate and usually have subparallel margins, there is considerable variation in details of the shape and in decoration of the wall. In some species the margins are nodose or undulate; some spiny. Usually there is a circle of granules around the poles of the cell. Some species are not so restricted in their distribution as most desmids, and may occur in basic or slightly alkaline waters as well as in acid or soft water habitats.

139a Cells with 2 star-shaped chloroplasts, one in each 'semicell.' Fig. 103

.CYLINDROCYSTIS

Fig. 103. Cylindrocystis Brebissonii Menegh.

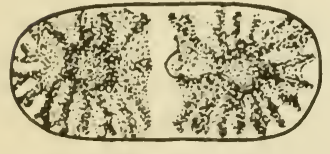

Figure 103

Although some of the half-dozen species of this genus have slightly constricted cells, they have a wall composed of one piece and have no wall pores, which thus identifies them as saccoderm (not true) desmids. There is one star-shaped chloroplast with a large pyrenoid in each half of the cell. This genus is not at all confined to acid habitats; may occur in alkaline bogs or among mosses, or may form gelatinous masses on wet stones in alpine situations.

139b Cell with other types of chloroplasts 
140a Cells short-cylindric, or subcylindrical; chloroplasts 1 in each 'semcell' (rarely 3 or 4 chloroplasts forming transverse zones in the cell); no vacuoles with moving granules in the poles of the cell.

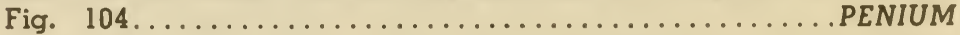

Fig. 104. Penium margaritaceum (Ehr.) Breb.

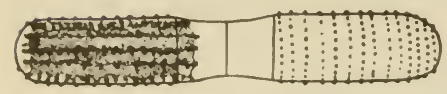

Figure 104

Some species of this genus are shaped like those of Cylindrocystis (Fig. 103) but have a wall of two pieces that adjoin in the midregion, and the wall usually shows punctations or granulations. In general, Penium cells are more cylindrical than Cylindrocystis and because new wall sections are built in when the cells divide, they may become as long as some small Pleurotaenium (Fig. 102).

140b Cells slightly attenuated at the apices; chloroplasts with several pyrenoids; vacuoles with moving granules in the poles of the cell. See Fig. $86 \ldots \ldots \ldots \ldots \ldots \ldots \ldots \ldots \ldots \ldots \ldots \ldots \ldots \ldots$ CLOSTERIUM

141 a (135) Chloroplasts spiral ribbons...................... 142

$141 \mathrm{~b}$ Chloroplasts some other shape................... 143

142 a Cells "cigar"-shaped, poles rounded. Fig. 105 ... SPIROT AENIA

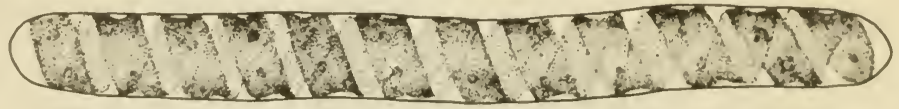

Figure 105

Fig. 105. Spirotaenia condensata Breb.

This "cigar"-shaped cell is usually straight but may be slightly curved. Although one species in the United States has an axial chloroplast, the others have a characteristic spirally twisted one in each cell. The cell is never constricted in the midregion and the wall is composed of 1 piece as in other saccoderm desmids.

142b Cells cylindrical with truncate ends. Fig. 106....GENICULARIA

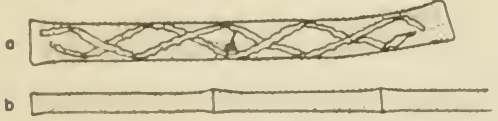

Figure 106

Fig. 106. Genicularia e le gan West. $a$, Single cell; b, filamentous arrangement.

The cells may be solitary or occur in filaments. Although the chloroplasts are spirally twisted and show a superficial resemblance to Spirogya (Fig. 147) this genus is usually identifiable by the cells being slightly enlarged at the poles. Genicularia is classified in the Gonatozygonaceae but is closely related to the desmids and is found associated with them in nature. 
143a (141) Cells cylindrical, 10 or more times the diameter in length. the poles truncate; wall spiny. Fig. 107.......GONATOZYGON

Fig. 107. Gonatozygon aculeatum Hastings.

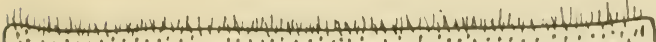
This desmid-like genus has solitary cells which are nearly always a little Figure 107 crooked; have walls bearing long or short spines; are not constricted at the midregion. Although usually free-floating and intermingled with desmids, the cells may be adherent to submerged plants. There is a ribbon-like chloroplast that is axial rather than parietal. As mentioned above, Gonatozygon may be classified with Genicularia to form the Gonatozygonaceae by some authorities, whereas others place it with the saccoderm desmids in the family Mesotaeniaceae.

143b Cells fusiform short-cylindric, less than 10 times the diameter in length; wall smooth...........................

144a Cells broadly fusiform or subcylindrical: 2 chloroplasts, one in each end of the cell, bearing longitudinal ridges, usually with notched margins. Fig. $108 \ldots \ldots \ldots \ldots \ldots \ldots \ldots \ldots$ NETRIUM

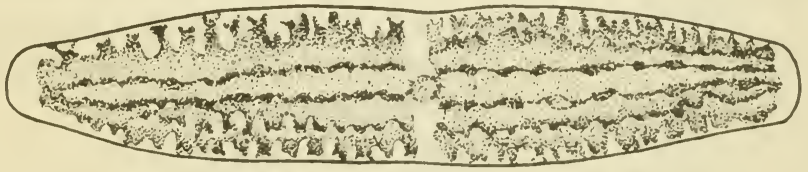

Figure 108

Fig. 108. Netrium digitus (Ehr.) Its. \& Rothe.

These are "watermelon"- or "cucumber"-shaped cells which are saccoderm desmids with scarcely any or no constriction in the midregion. Like other members of the family the cell contents are conspicuously symmetrically divided into two portions, there being 1 (rarely more) longitudinally ridged chloroplasts in each half of the cell. There are 5 or 6 species in this country, differentiated by shape and proportions of the cell.

144b Cells cylindrical or narrowly fusiform, with 1 chloroplast in the

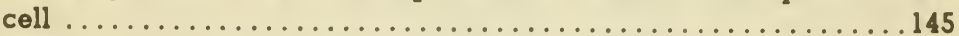

145a Cells "cigar"-shapedi chloroplast axial with 4-6 pyrenoids. Fig. 109 ........................................ ROY

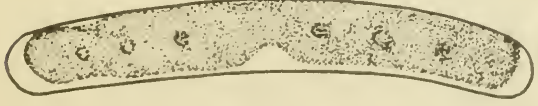

Figure 109

Fig. 109. Roya obtusa (Breb.) West \& West.

This rather rare saccoderm desmid has slightly curved cylindrical cells in which there is but a single chloroplast that is notched in the midregion where the nucleus is located. 
145b Cells elongate-ellipsoid or ovoid to subcylindrical; I parietal chloroplast; cell contents violet-colored. See Fig. 46. .MESOT AENIUM

146a (126) Cells constricted in the midregion................. 147

146b Cells not constricted in the midregion................

147a Cells flat, nearly circular in proportions, star-like in front view, the median incision very deep; semicells deeply lobed or incised, in some species forming secondary lobes and lobules. Fig. $110 \ldots \ldots \ldots \ldots \ldots \ldots \ldots \ldots \ldots \ldots \ldots \ldots \ldots$. . . . . . . . . . .

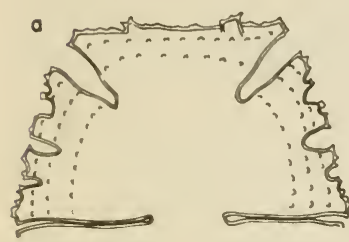

Fig. 110. a, Micrasterias americana var.; Boldtii Gutw.; b, M. radiata Hass. var.; c, M. foliacea Bailey.

These are true desmids and include some of the most beautiful microscopic objects. Although the outline of the cell varies greatly among the twenty or more species in this country, they can be identified by the flat, disc-like shape. One species, $M$. foliacea Bailey, has hooks on the polar lobes which enmesh with those of adjoining, newly-formed cells so that false "filaments" are produced.

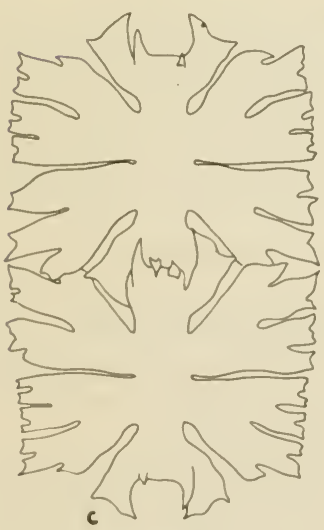

Figure 110

147b Cells not flat and disc-like....................... 148 
148a Cells with a shallow and broad, or a deep and narrow notch in the apex of the semicell. Fig. $111 \ldots \ldots \ldots \ldots \ldots$.........

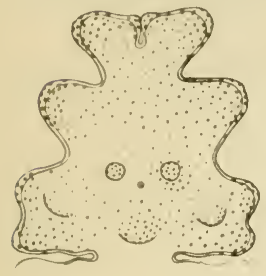

2.

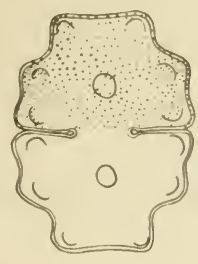

b

Figure 111

Fig. 111. a, Euastrum pinnatum Ralfs; b, E. pectinatum var. inevolutum West \& West.

There are numerous species in this desmid genus, varying greatly in size and shape of cell. Most of them, however, have a polar notch in the semicells and, characteristic of the genus, have more or less prominent protrusions and swellings on the face of the semicell. In filled cells the latter are difficult of determination, especially in the smaller species. The specimens need to be rolled so that they can be seen from the side or top when making microscopic examinations. Nearly all of the species of Euastrum are limited to an acid habitat.

148b Cells without $\alpha$ notch in the apex of the semicell...........149 149a Apex of the cell extended into 2 or more arms or lobes, the arms usually extending radiately so that the cells are star-shaped or triangular when seen from the top (end view). Fig. $112 \ldots \ldots \ldots$

.ST AURASTRUM

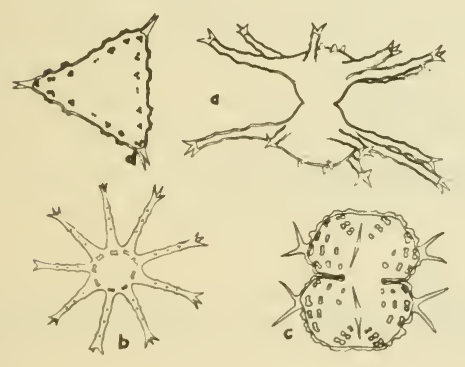

Figure 112

Fig. 112. a, Staurastrum rotula Nordst., 'front' or side view; $b$, end view; c, St. cornutum Arch.; $d$, end view.

This is a large desmid genus with several hundred species which vary in shape of semicell and type of decoration on the wall. The chief distinguishing characteristic is the extension of lobes or arms in at least 3 planes so that the cell appears radiate when seen from the top. Many species appear like Cosmarium (Fig. 113) when seen in front view and one needs to change the plane of focus in order to see the semicell extending up toward the observer, or down as the case may be. $\AA$ few species have arms in 1 plane only and these are retained in the genus by virtue of the fact that the shape and decorations of the arms (spines, verrucae, etc.) are those of Staurastrum. Some species are definitely euplanktonic and have long arms which give them buoyancy, whereas others are tychoplanktonic and are intermingled with other desmids in acid swamps.

149b Apex of semicell not extended into arms, or if with arms these not radiating in 3 planes......................... 50 
150a Semicells with 2 extended arms at their apices as seen in front view, narrowly elliptic when seen from the top. See Fig. 1121/2.

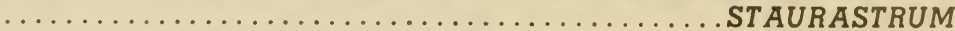

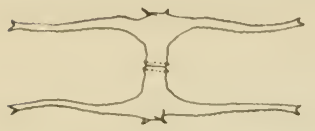

Fig. 1121/2. Staurastrum leptocladum Nordst.

150b Semicells compressed or rounded when seen from the top or side, not with radiating arms........................

15la Margin of cell furnished with spines.

151b Margin of cell without spines, although sometimes granular. Fig. 113 COSMARIUM

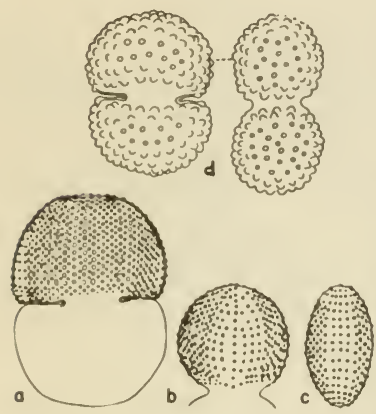

Fig. 113. a-c. Comarium panamense Presc.; b, side view; c, top view; $d, C$. margaritatum (Lund.) Roy \& Biss., front and side view.

Like the genus Staurastrum (Fig. 112) Cosmarium includes several hundred species with considerable variation in shape of semicell and manner of wall decoration (granules, teeth, scrobiculations). Nearly all are compressed or rounded when seen from the side or top, regardless of their shape when seen from the front or broad side.

Figure 113

152a Face of semicell with protuberances or with the wall thickened in the midregion (best seen when the cell is rolled to a lateral view position) . ............................ 153

152b Face of semicell without swellings or protuberances. Fig. 114. ARTHRODESMUS

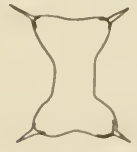

Figure 114

Fig. 114. Arthrodesmus incus (Breb.) Hass.

This genus has compressed cells like Cosmarium but the angles bear relatively stout spines. The wall is smooth in this genus, there being no granules, pits or swellings. 
153a Apex of semicell furnished with prominent spines; facial protuberance (if any) one large low swelling, the wall thickened here and often pitted or punctate. Fig. $115 \ldots \ldots \ldots \ldots \ldots$ XANTHIDIUM

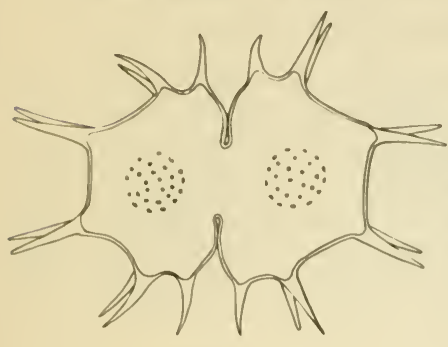

Figure 115

Fig. 115. Xanthidium cristatum var. uncinatum Hass.

This genus too, like Arthrodesmus (Fig. 114) has cells that are compressed so that they are narrow when seen from the side or top. There is usually a facial swelling in the center of the semicell and all angles bear stout spines or short arms that are tipped with spines.

Some forms have granules on the wall. There is less variation in the shape of the semicell in this genus than in some of the other desmids.

153b Apex without spines or with a short, tooth-like spine at either side. See Fig. Ill.....................EUASTRUM

154a (146) Cells spherical, inclosed by a spindle-shaped envelop which has longitudinal ridges. See Fig. $97 \ldots \ldots \ldots$ DESMATRACTUM

154b Cells not inclosed in such an envelope................. 55

155a Cells oval, ovoid, spherical or ellipsoid..............156

155b Cells angular, pyramidal, trapeziform, or polygonal.........183 
156a Cells subcylindrical or ovoid, small, less than $4.5 \mu$ in diameter, with a parietal plate-like chloroplast at one or both ends. Fig. 116

NANNOCHLORIS

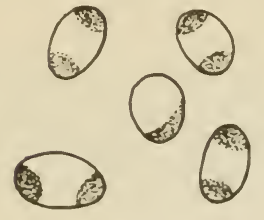

Figure 116

Fig. 116. Nannochloris bacillaris Naum.

These tiny cells are solitary and are without a gelantinous sheath. They are able to undergo cell division in vegetative reproduction and hence are assignable to the Coccomyxaceae along with Elakatothrix (Fig. 38) and Dactylothece (Fig. 47). It is a frequenter of laboratory culture.

156b Cells different in size and shape, or with a different type of chloroplast ............................... 157

$157 \alpha$ Cells bearing spines or decorated with ridges........... 158

157b Cells without spines or decorations.................. 164

158a Spine length greater than the diameter of the cell........159

158b Spine length less than the diameter of the cell; wall usually decorated with a network of thickenings...............163

159a Spines not tapering from base to apex, long and slender.....161

159b Spines tapering to apex, long and slender, or short and stout. . 160

160a Spines stout, broad at the base and tapering. Fig. $117 \ldots \ldots \ldots$ ECHINOSPHAERELLA

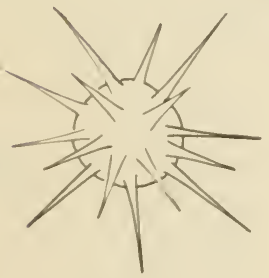

Figure 117
Fig. 117. Echinosphaerella limnetica G. M. Smith.

This is a relatively rare species from the euplankton. In making identification care should be used in distinguishing the single parietal chloroplast by which the plant may be differentiated from some of the spiny zygospores of desmids (in which the cell content appears dark and massive, with no definitely shaped chloroplast distinguishable). 
$160 \mathrm{~b}$ Spines long and slender, gradually tapering in the basal part for a short distance, and then abruptly narrowed to a needle. Fig. $117 \frac{1 / 2}{2}$

ACANTHOSPHAERA

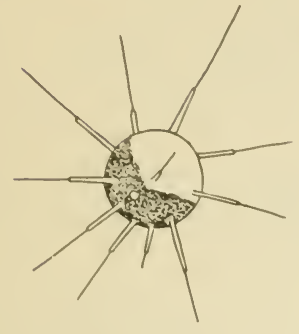

Figure $1171 / 2$

Fig. 1171/2. Acanthosphaera Zachariasi Lemm.

This plant can be distinguished from Echinosphaerella (Fig. 117) because the spines are long and somewhat needle-like, arising from a base which is decidedly thicker than in the outer section.

161a (159) Cells round. See Fig. $84 \ldots \ldots \ldots \ldots \ldots \ldots$ GOLENKINIA

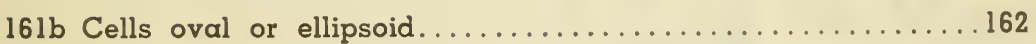

$162 \alpha$ Spines at the poles or at the equator of the cell. Fig. 118

LAGERHEIMIA (CHODATELLA)

Fig. 118. a, Lagerheimia longiseta (Lemm.) Printz; b, L. quadriseta (Lemm.) G. M. Smith.

Unlike Franceia (Fig. 73) cells of this genus have long, needle-like spines confined to the poles or to the poles and the equator. There are 3 or 4 species reported from this country which are differentiated on the basis of cell shape and arrangement of spines. All are fairly common in the euplankton.

Figure 118

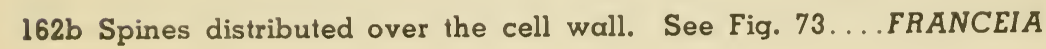




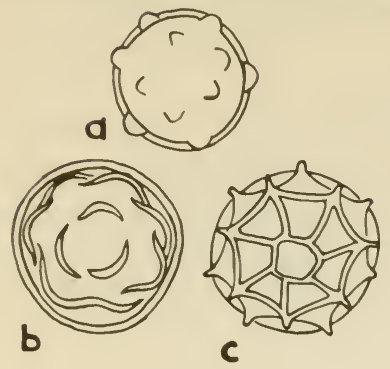

Figure 119

Fig. 119. a, Trochiscia granulata (Reinsch) Hansg.; b, T. obtusa (Reinsch) Hansg.; c, T. reticularis (Reinsch) Hansg.

There are 5 or 6 species of this genus, all solitary cells, which may be differentiated by the type of wall decoration. It is a little-understood genus and some of the described species are doubtless the zygospores of other algae. Some may be the encysted or resting stages of still other forms. In making identification of plants with the outward characteristics of Trochiscia care should be used in identifying the several disc-like chloroplasts which this genus possesses.

163b Cells oval. Fig. 120

BOHLINIA

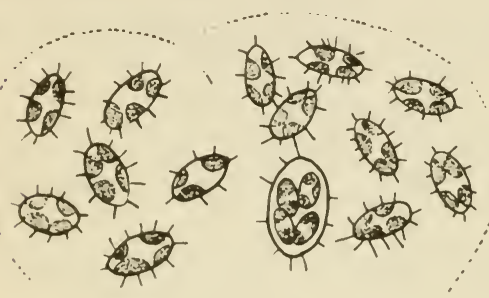

Figure 120

Fig. 120. Bohlinia echidna (Bohlin) Lemm.

This rather unique species (the only one in the genus) appears in amorphous gelatinous masses. Reproduction is by internal cell division to form autospores. Although older cells are characteristically spiny recently formed individuals may be smooth-walled. The observer should examine the plant mass for remains of the old cell walls which will show evidence of the spinescence.

164a (157) Cells associated with fungi to form thalli of lichens. Fig. 121 TREBOUXIA

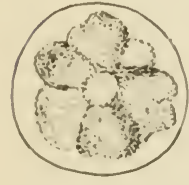

Figure 121

Fig. 121. Trebouxia Cladoniae (Chod.) G. Mi. Smith.

This species is an inhabitor of lichens and apparently occurs nowhere else. The cells are spherical and contain an axial rather than a parietal chloroplast like most of the other members of the Chlorococcales.

$164 \mathrm{~b}$ Cells not associated with fungi in lichens

165a Chloroplast 1, central, with radiating lobes extending to the wall 
$165 \mathrm{~b}$ Chloroplast not axial, or more than 1 in a cell, without radiating arms .167

166a Chloroplast definitely star-shaped with a central pyrenoid: cells spherical. See Fig. $51 \ldots \ldots \ldots \ldots \ldots \ldots \ldots$ ASTEROCOCCUS

166b Chloroplast irregularly lobed, not symmetrically radiate, without a pyrenoid: cells pyriform. Fig. $122 \ldots \ldots \ldots \ldots \ldots$ MYMECIA

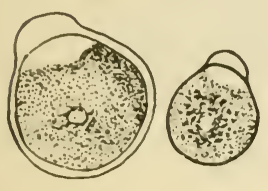

Figure 122

Fig. 122. Myrmecia aquatica G. M. Smith (redrawn from Smith).

These cells are either spherical or somewhat pear-shaped and usually show a thickening of the wall at one side, giving them an unsymmetrical shape. Although the genus was originally described from aerial situations, specimens in this country have been collected from aquatic habitats.

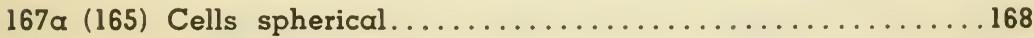

167b Cells oval or ellipsoid 174

168a Cells large, wall thin: chloroplast irregular in shape and lumpy with starch grains, arranged in radiating strands from the center of the cell, and also parietal. Fig. 123......EREMOSPHAERA

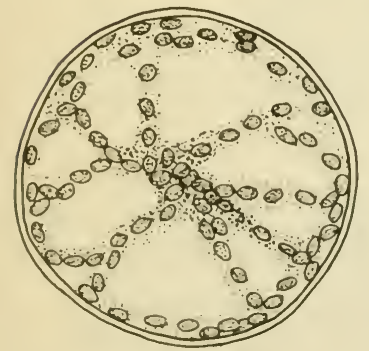

Figure 123
Fig. 123. Eremosphaera viridis De Bary.

This is one of the largest spherical cells (up to 800 microns in diameter) encountered among the unicellular algae. Although usually solitary it may appear in clusters within the old mother-cell wall. There is one other rare species (with oblate-spheroidal cells) but the plant illustrated is fairly common in habitats where desmids abound. The numerous disc-like chloroplasts are often lumpy and irregular in shape because of the starch grains which collect about them. 
$170 \alpha$ Cells eccentrically placed in a sheath which has numerous lamellations (layers); pyrenoid lacking. Fig. 124.....UROCOCCUS

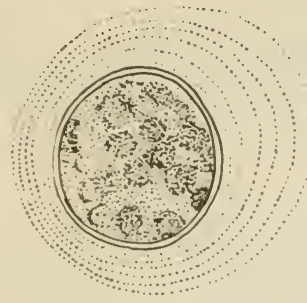

Figure 124

Fig. 124. Urococcus insignis (Hass.) Kuetz.

Although holding a place in the Tetrasporales according to its assignment in the past, this reddish-colored cell has been shown to be an encysted stage of one of the motile Dinoflagellates (Pyrrhophyta). Unless other species are shown to be separable and distinctive, the genus may be reduced to synonymy.

170b Cells centrally placed in a sheath which has few or no lamellations; pyrenoid present; (usually colonial, sometimes solitary). See Fig. $41 \ldots \ldots \ldots \ldots \ldots \ldots \ldots \ldots \ldots \ldots \ldots \ldots \ldots \ldots \ldots \ldots$ GLOESTIS

171 a (169) Chloroplast 1 ; cells solitary (often gregarious)........ 172

$17 \mathrm{lb}$ Chloroplasts more than 1; (cells usually ellipsoid in a gregarious association but sometimes round). Fig. 125..PALMELLOCOCCUS

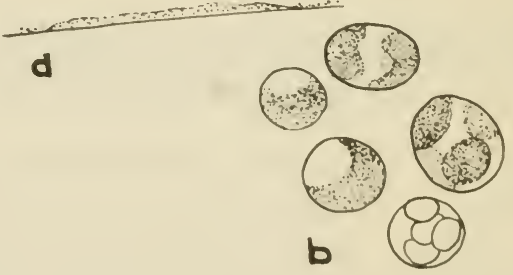

Figure 125

Fig. 125. Palmellococcus miniatus (Kuetz.) Chod. a, habit of colony; b, portion of colony showing cells with Chlamydomonas-like chloroplast.

These oval or spherical cells usually occur as films on moist substrates (rocks, cement walls, etc.). There are 1 to several chloroplasts without pyrenoids. Reproduction is by the formation of autospores (Chlorococcales). Identification is difficult unless the organisms are cultured because there are so many minute green cells which might be confused with this genus. 
172a Cells associated to form an extended stratum on trees, wood, stones. See Fig. $66 \ldots . . . .$. PROTOCOCCUS (PLEUROCOCCUS)

$172 \mathrm{~b}$ Cells not forming such a stratum...................... 173

173a Chloroplast a thin layer along the wall; pyrenoid usually lacking; free-living or in tissues of animals (sponges, etc.), reproducing by autospores (replicas of the adult cell). See Fig. $91 \ldots . .$. .......................... CHLORELLA (ZOOCHLORELLA)

173b Chloroplast a massive cup with a pyrenoid; on damp aerial substrates; reproducing by zoospores. See Fig. $42 \ldots \ldots \ldots \ldots \ldots$.

174a (167) Cells oval, ovate, or irregular globose, with thick-layered walls bearing knobs and protrusions................. 175

174b Cells without thick walls and knob-like protrusions.........176

$175 a$ Chloroplasts numerous, parietal, cone-shaped. Fig. $126 . . \ldots \ldots$ EXCENTROSPHAERA

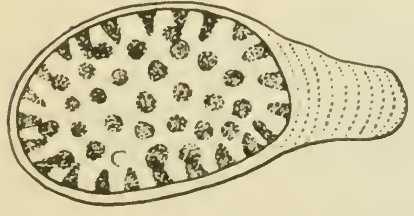

Figure 126

Fig. 126. Excentrosphaera viridis G. T. Moore.

This is the only species reported for the genus. It is found in the water or in very wet soil and is identified by its irregular shape produced by a lamellated thickening of the wall in one or more places. The chloroplasts are cone-shaped and all are directed inwardly from their parietal position along the wall. 
175b Chloroplast a massive, axial body with processes which are flattened against the wall. Fig. $1261 / 2 \ldots \ldots \ldots$ KENTROSPHAERA

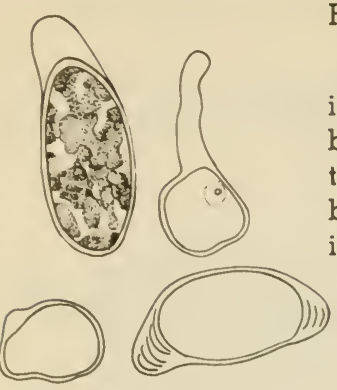

Fig. 1261/2. Kentrosphaera Bristolae G. M. Smith.

There are 2 or 3 species of this genus (often included in the genus Chlorochytrium (Fig. 94) but only $K$. Bristolae has been reported from this country. The cells are similar in shape but have a free-living habit, usually occurring in damp soil.

Figure $1261 / 2$

176a (174) Cells with spines.......................... 177

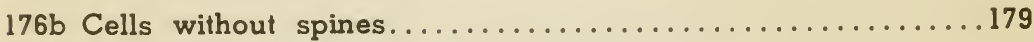

177 . Spines distributed over the cell wall................. 178

177b Spines localized at the poles or at the midregion of the cell. See Fig. $118 \ldots \ldots \ldots \ldots \ldots \ldots \ldots \ldots$...................

178a Spines shorter than the diameter of the cell. See Fig. 120.... BOHLINIA

178b Spines needle-like, as long as or longer than the diameter of the cell; cell solitary or in 2 's. See Fig. $73 \ldots \ldots \ldots \ldots \ldots$ FRANCEIA

179a (176) Cells with spiral, longitudinal ribs on the walls. Fig. 127. SCOTIELLA

Fig. 127. Scotiella nivalis (Chod.) Fritsch.

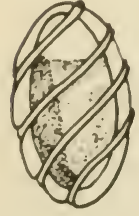

Figure 127

This genus contains a number of species, most of which have been collected in the flora of red snow at high altitudes. Differences lie in the shape of the cell and the type of ridged decorations on the wall. Occasionally Scotiella species are collected in the tychoplankton at low altitudes. Some authorities place this genus in the Volvocales because of the type of chloroplast and the evidence of basal-distal differentiation in the cell; whereas others include it with the Chlorococcales. 
$179 \mathrm{~b}$ Cells without longitudinal ribs

180a Cells small, less than $4.5 \mu$ long, with a plate-like chloroplast at one end. See Fig. 116............. ANNOCHLORIS

$180 \mathrm{~b}$ Cells relatively large, without such a chloroplast.

181a Two or more masses of dark mucilage appearing at either end or on either side of the cell; usually $2-4$ cells in a cornmon investment, but often solitary. See Fig. 83.........GLOEOT AENIUM

$181 \mathrm{~b}$ Without dark masses of mucilage about the cells......... 182

182 Cells oval, often solitary but usually gregarious, forming an expanse on moist aerial substrates. See Fig. 125.

PALMELLOCOCCUS

182b Cells lemon-shaped oval or ellipsoid (usually several together in old mother-cell wall, but may occur solitary); aquatic. See fig. 85 .OOCYSTIS

183a (155) Cell body actually spherical but with 4 long, narrow, brown arm-like appendages radiating from it. Fig. 128. PACHYCLADON

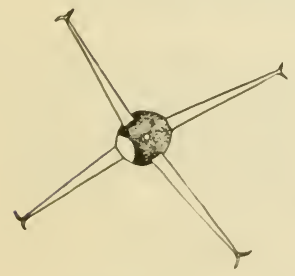

Figure 128
Fig. 128. Pachycladon umbrinus G. M. Smith. (Redrawn from Smith.)

This rare plant (one species in the genus) occurs in the euplankton of lakes. The long, darkly colored appendanges from a relatively small, subspherical cell body make it easy of identification. 
184a With several long spines forming a tuft at the angles of the cell. (See Polyedriopsis quadrispina, however) at the angle of the cell. Fig. 129

POLYEDRIOPSIS

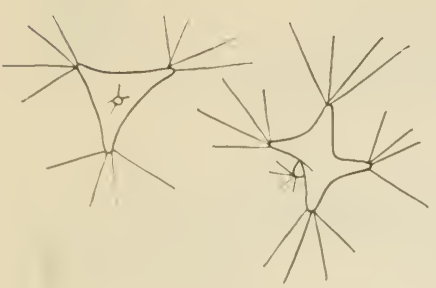

Figure 129

Fig. 129. Polyedriopsis spinulosa G. M. Smith.

There are 2 species in this genus, both of which are euplanktonic. They are rectangular or polyhedral in shape with from 1 to 4 long spines at each angle. $P$. quadrispina G. M. Smith has but 1 stout spine at each angle; is quadrate in shape.

$184 \mathrm{~b}$ With 1,2, or 3 spines, or without spines at the angles of the cell

185a Without spines

$185 \mathrm{~b}$ With 1-3 spines at the angles.

186a Body of the cell gradually narrowed at the angles to form hornlike, twisted processes. Fig. $130 \ldots \ldots \ldots \ldots$ CERASTERIAS

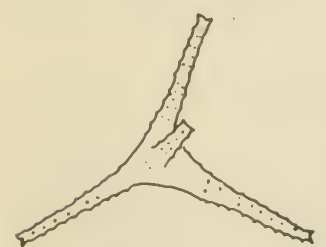

Figure 130

Fig. 130. Cerasterias irregulare G. M. Smith.

There is apparently only 1 good species in this genus which is characterized by having irregularly triangular cells with twisted processes. Occurs in the euplankton. Should be compared with Tetraedron (Fig. 131). 
186b Body of the cell abruptly narrowed to form horn-like processes. Fig. $131 \ldots \ldots \ldots \ldots \ldots \ldots \ldots \ldots \ldots \ldots \ldots \ldots \ldots \ldots \ldots$ TETRAEDRN
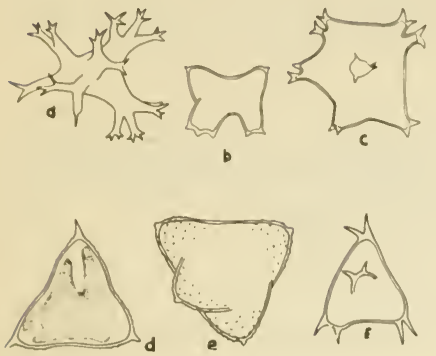

Figure 131

Fig. 131. $\alpha$, Tetraedron limneticum Borge; b, T. asymmetricum Presc.; c, T. lobulatum var. crassum Presc.; d, T. regulare var. granulatum showing chloroplast; e, T. regulare var. granulatum Presc.; f, T. regulare var. bifurcatum Wille.

This genus contains a large number of species which vary considerably in their shape and in the number of arms or processes. Whereas some are simple and have rounded angles, others are polyhedral in shape and have varying degrees of lobings at the angles. They occur both in the euplankton and in the tychoplankton.

187a (185) Cells with 1 spine at each angle................. 188

187b Cells with 2 or 3 spines at the angles. Fig. 13lb...TETRAEDRON

188a Spines slender and needle-like. See Fig. 129...POLYEDRIOPSIS

188b Spines broader at the base and stout, decidedly tapering. Fig. 132 TREUBARIA

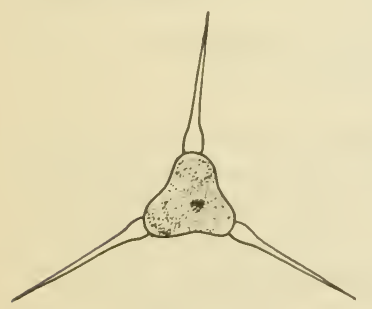

Figure 132

Fig. 132. Treubaria crassispina G. M. Smith. This free-floating plant is similar to Pachycladon (Fig. 128) but the processes are not darkly colored and are not toothed at the tip. 
189a (35) Plant a microscopic unbranched filament, attached or freefloating: or a macroscopic thallus in the form of an expanded sheet, a tube, or an arbuscular (tree-like) gelatinous and beaded growth 190

$189 \mathrm{~b}$ Plant $a$ branched filament, $a$ coenocytic tube (without cross walls) or an attached cushion or disc in which the branching habit is obscure because of closely appressed branches...........241

190a Cells constricted in the midregion, with 2 large chloroplasts, one in either 'semicell'............................191 (In some species of filamentous desmids the constriction is very slight, being only a slight invagination or concavity of the lateral walls. See illustrations of Hyalotheca, Fig. 137, and of Gymnozyga, Fig. 136 before proceding in the key.)

$190 \mathrm{~b}$ Cells not constricted in the midregion

19la Cells adjoined by the interlocking of short, straight, horn-like or hooked processes at the poles..................... 192

$191 b$ Cells adjoined by their end walls, either along the entire apical surface, or at the ends of arms which project from the apex..194

192a Interlocking polar processes simple, slender and horn-like. Fig. 133 ONYCHONEMA

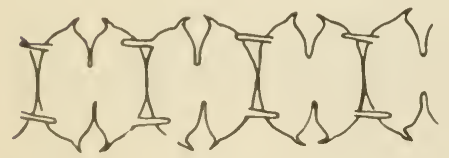

Figure 133

Fig. 133. Onychonema laeve var. latum West \& West.

There are 2 rather common species of this filamentous desmid genus. O. filiforme (Ehr.) Roy \& Biss. has the lateral angles ot the semicells furnished with a spine and the polar processes are

relatively long. O. laeve Nordst. has cells without lateral spines and appears like a small Cosmarium (Fig. 113) in a filament, the cells adjoined by short (sometimes scarcely evident) polar processes. 
192b Interlocking polar processes not slender and horn-like

193a Interlocking processes in the form of forked lobes which bear recurved hooks. See Fig. $110 \ldots \ldots \ldots \ldots \ldots$ MICRASTERIAS

193b Interlocking processes simple, short and tuberculate. Fig. 134. .SPHAEROZOSMA
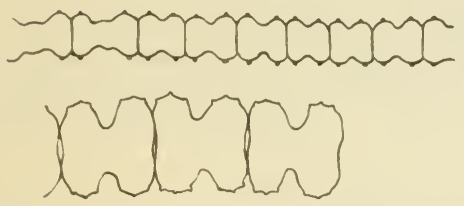

Figure 134

Fig. 134. Sphaerozosma excavata Ralfs.

This is a filamentous desmid in which the cells are adjoined by the interlocking of the polar processes themselves. None of the species bear spines but they usually have minute granules at the angles of the semicell, or forming transverse bands across the semicell. This genus usually occurs in acid lakes, intemingled with other desmids.

194a (191) Semicells transversely elliptic or oval, the median incision of the cell deep. Fig. $135 \ldots \ldots \ldots \ldots \ldots$. SPONDYLOSIUM

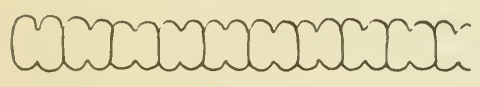

Figure 135

Fig. 135. Spondylosium sp.

Although this genus can have cells that are triangular in end view, most species have cells. that are compressed and are somewhat like Cosmarium (Fig. 113) in a filament. One species which is rather rare is S. pulchrum (Bail.) Archer. It has semicells which are much extended laterally so that the cell is much wider than long. The apices of the cells in this are furnished with a protrusion which adjoins that of the adjacent cells in the filament. The walls are smooth and undecorated.

194b Semicells not transversely elliptic, median incision not deep, sometimes only a slight concavity of the lateral wall......195

195a Cells cylindrical, subcylindrical, or barrel-shaped........196

195b Cells quadrate or angular, usually with the margins conspicuously lobed. (See Fig. 138b, Desmidium Baileyi, however)...... 197 
196a Cells barrel-shaped, with a slight notch-like median incision in the broadest part of the cell where it is somewhat bulged. Fig. 136

Fig. 136. Gymnozyga moniliformis Ehr.

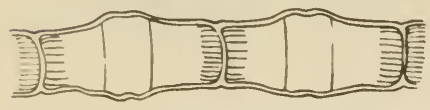

Figure 136

There are 3 species of this genus found in the United States, differentiated mostly on the size and proportions of the cell, but none are as common as the one illustrated. This species occurs sometimes almost pure in pools within Sphagnum bogs, and is a common component of the desmid flora of almost any soft or acid water habitat. G. moniliformis is characterized by having barrel-shaped cells that have longitudinal striations in the apical portion of the semicells. These are sometimes faintly seen, especially in living cells when the chloroplast obscures them.

196b Cells cylindrical or somewhat rectangular, with a broad and shallow emargination rather than an incision in the midregion. Fig. $137 \ldots \ldots \ldots \ldots \ldots \ldots \ldots \ldots \ldots$....................

(See also Desmidium Baileyi, Fig. 138b.) Fig. 137. Hyalotheca dissiliens (Smith) Breb.

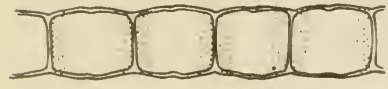

Figure 137

There are 3 or 4 common species of this genus, differentiated by cell shape and proportion, some being short and nearly quadrate whereas others are cylindrical. In some individuals the constriction of the cell occurs only as a shallow invagination in the median part. In Sphagnum bogs small pockets of water or pools in the mat may be densely green with a pure growth of $H$. mucosa (Dill.) Ehr., a species which has a conspicuous gelatinous sheath.

197 a Cells wider than long or as wide as long, without a median incision or with but a slight median notch; walls at the poles of young semicells infolded or replicate. Fig. 138....DESMIDIUM

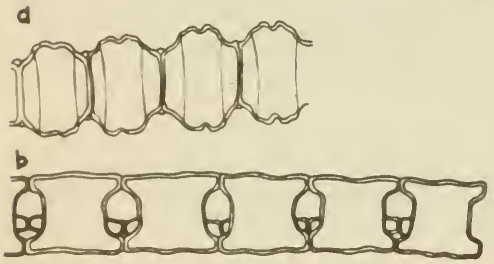

Figure 138

Fig. 138. a, Desmidium Grevillii (Kuetz.) De Bary; b, D. Baileyi (Ralfs) Nordst.

Cells of this filamentous desmid genus vary much in shape. Some are oval and moniliform when seen in end view, some are triangular, and some are quadrangular. The shape of the cell may be determined by careful focusing

up and down through the depth of a specimen. A characteristic habit of some species is to show a spiral twisting of the cell arrangement so that in any one view they do not have their processes in the same plane throughout the length of the filament. Desmidium usually occurs in the same habitats with Hyalotheca (Fig. 137). 
197b Cells a little longer than wide, rectangular, with a narrow median incision; 4-lobed in end view; poles of young cells infolded. Fig. 139.

PHYMATODOCIS

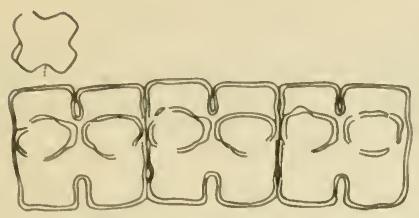

Figure 139

Fig. 139. Phymatodocis Nordstedtiana Wolle.

Although rarely found this filamentous desmid may be the dominant form in some habitats that are especially favorable. The cells appear somewhat quadrangular when seen in front view (as they occur in the filament) but are quadrilaterally symmetrical and are 4-lobed as seen in end view.

198a (190) Chloroplast parietal, of various shapes, net-like, ring-like, or plate-like, with pads and thin areas (Fig. 1391/4); or if axial, plants in the form of a macroscopic thallus as in Fig. 153 ..........................210

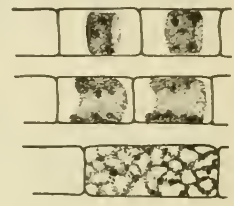

Figure $1391 / 4$

198b Chloroplast axial, a broad band, or starshaped; if parietal, in the form of a ribbon as in Fig. 1391/2: microscopic......... 199

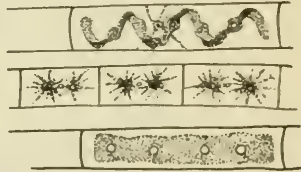

Figure 1391/2

(The following genera are determined with difficulty when in the vegetative condition alone; reproductive structures and 'fruiting' stages are often necessary for completely satisfactory identification.)

199a Chloroplast 1 or 2 in a cell; stellate, with radiating processes from a central core which includes a pyrenoid.............200

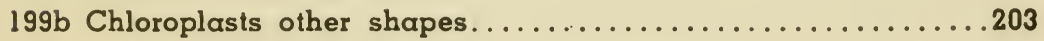


200a Cells quadrate, with 1 star-shaped chloroplast containing a single pyrenoid. Fig. $140 \ldots \ldots \ldots \ldots \ldots \ldots \ldots$. . . . . . . .

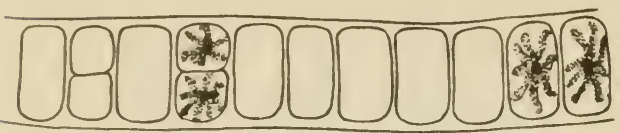

Figure 140

Fig. 140. Schizogonium murale Kuetz.

This species and 1 other, S. crenulatum (Kuetz.) Gay with short, crinkly filaments, are found in the United States, growing on dripping rocks, or wet soil. The basically filamentous habit may become expanded so that a frond-like thallus is produced. This genus, together with Prasiola (Fig. 153) have sufficient structural and reproductive characteristics to warrant placing them in a separate family (Schizogoniaceae) and order (Schizogoniales). The star-shaped chloroplast is helpful in making determinations.

200b Cells mostly longer than wide; 2 chloroplasts.

201a Chloroplasts 2-6 relatively small and biscuit-shaped or somewhat star-shaped, connected in the midregion of the cell by $\alpha$ strand of cytoplasm inclosing the nucleus; conjugating cells becoming filled with layers of pectic substance; zygospores cushion-like, compressed spheroid, or subquadranguler. Fig. $141 \ldots \ldots \ldots \ldots$
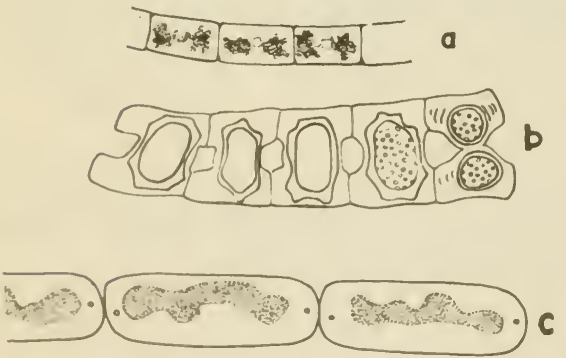

Figure 141

Fig. 141. a. Zygnemopsis decussata (Trans.) Trans., vegetative cells with cushion-like chloroplasts; b, conjugation to form zygospores; c, Z. desmidioides (West \& West) Trans.

The differences between this genus and Zygnema occur mostly within the reproductive habit so that determination of plants in the vegetative condition is not certain. The irregular, biscuit-shaped chloroplasts are not conspicuously star-shaped as they usually are in Zygnema, a genus which is more commonly found and which includes more species than does Zygnemopsis. 
201b Chloroplasts different in shape, or if star-shaped, larger than above, and always 2; conjugating cells not becoming filled with pectic substances; zygospores globose, compressed globose, or oval ....................................202

202a Chloroplasts 2, definitely star-shaped, each containing a large central pyrenoid; aquatic. Fig. $142 \ldots \ldots \ldots \ldots \ldots \ldots$ ZYGNEMA

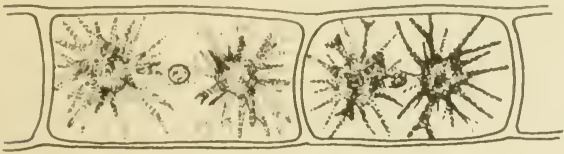

Figure 142

Fig. 142. Zygnema pectinatum (Vauch.) C. A. Agardh, vegetative cells showing star-shaped chloroplast.

There are numerous species of Zygnema, differentiated on the basis of the zygospore morphology. The paired, star-shaped chloroplasts in each cell make identification of the genus reasonably certain. Frequently the cells cre so densely packed with starch grains and cytoplasmic granules that the shape of the chloroplast is difficult of determination. Application of an iodine solution often facilitates observation, or if one examines several lengths of filaments under low magnification the stellate form of chloroplasts will become apparent. A few species have a conspicuous gelatinous sheath.

202b Chloroplasts ax:al as above but with radiating processes much reduced, sometimes bridged so as to form a dumb-bell shaped mass; terrestrial. Fig. $143 \ldots \ldots \ldots \ldots \ldots \ldots \ldots$. $\ldots$ YGOGONIUM

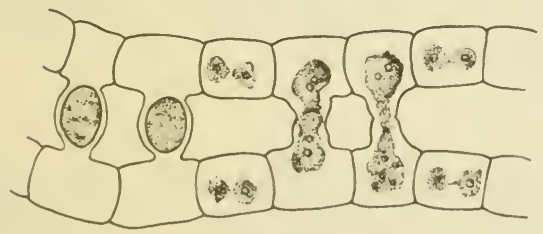

Figure 143

Fig. 143. Zygogonium ericetorum Kuetz.

These filaments are somewhat irregular bocause the cell walls are unevenly thickened and usually are invested by a layer of mucilaginous substance. The cells have the habit of putting out frequent rhizoidal protrusions which may branch. Sometimes the conjugation tubes (when they fail to meet other tubes) will continue to grow as rhizoidal processes. The plant is usually found in aerial or subaerial habitats (occasionally in the water on submerged stumps, etc.).

203a (199) Cell sap purplish............................204

203b Cell sap not purplish............................... 
Fig. 144. Pleurodiscus purpureus

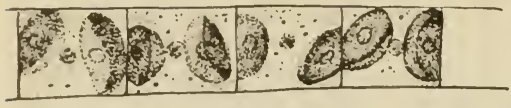
(Wolle) Lag., showing disc-like chloroplasts.

Figure 144

There is but one species of this genus reported thus far from the United States. It is a plant easily identified by its unique, plate-like chloroplasts and purple cell sap.

204b With 1 band-like chloroplast. Fig. 145.........MOUGEOTIA

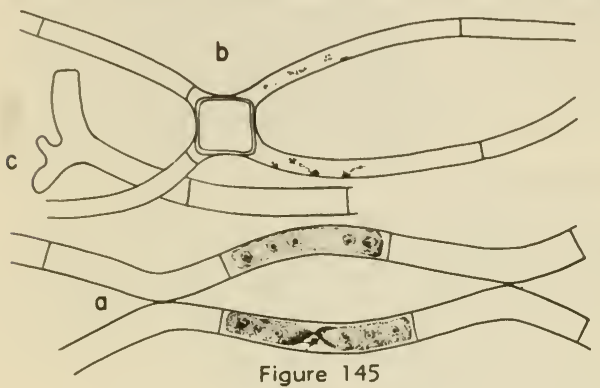

Fig. 145. a, Mougeotia genuflexa (Dillw.) C. A. Agardh, showing geniculate or 'knee-bending' type of conjugation and the plate-like axial chloroplast; b, M. elegantula Wittr., zygospore with residues in conjugation cells; c, $M$. sp., showing rhizoidal branches.

Like Spirogyra (Fig. 147) there are many species of Mougeotia separable by zygospore shape and wall markings. Most species have a relatively wide, band-like chloroplast containing a row of large pyrenoids. The chloroplast (axial) is capable of rotating within the cells so that the band, when seen on edge, appears as a narrow ribbon. The shifting of the chloroplast is supposed to be a response to the direction of more favorable illumination.

205a (203) Chloroplasts in the form of spiral ribbons, with many pyrenoids .206

205b Chloroplasts axial bands or plates; pyrenoids 2 to several..208 $206 \alpha$ Cell wall densely and minutely granular. See Fig. 106....... GENICULARIA 
207a Chloroplasts nearly parallel, only -slightly iwisted; conjugation without the formation of tubes. Fig. 146........ SIROGONIUM

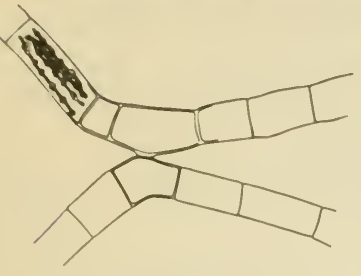

Figure 146

Fig. 146. Sirogonium sticticum (Engl. Bot.) Kuetz., showing parallel chloroplasts.

This genus is differentiated from Spirogyra (Fig. 147) on the shape and arrangement (nearly straight and parallel) of the ribbonlike chloroplasts, and (in reproductive material) by the absence of a conjugation tube between the cells of adjoined filaments. There is geniculation of filaments to bring the conjugating cells into juxtaposition.

207b Chloroplasts definitely spiralled; conjugation by the formation of tubes from one or both cells, either between cells of two different filaments (scalariform conjugation), or between adjacent cells in the same filament (lateral conjugation). Fig. $147 \ldots \ldots$

SPIROGYRA

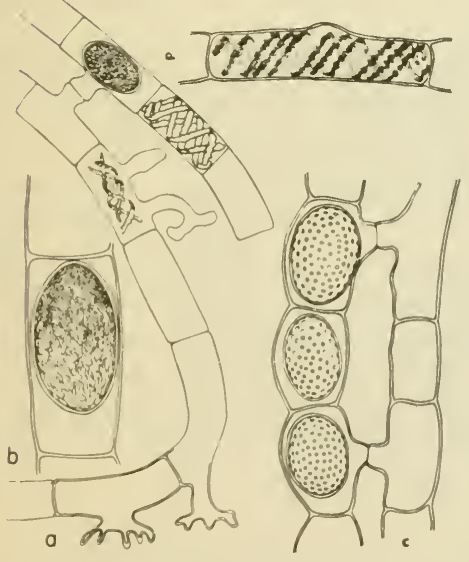

Figure 147

Fig. 147 a, Spirogyra rhizobrachiales Jao, showing rhizoidal branches and conjugation; $b$, zygospore; $c$, S. aequinoctialis G. S. West; d, cell showing chloroplasts and numerous pyrenoids.

This is the most commonly found member of the entire order of Zygnematales. There are numerous species differentiated on the morphology of the zygospore, number of chloroplasts, and size. Chloroplasts alone, and size of cell do not distinguish species in this genus, and identitification of vegetative material cannot be made. Spirogyra forms green 'clouds' of cottony growths, usually in quiet water. In the reproductive state the plants appear at the surface, forming cottony mats ('pond scums') and become brown or 'dirty' colored. 
208a. (205) Chloroplasts without pyrenoids. Fig. 148.

MOUGEOTIOPSIS

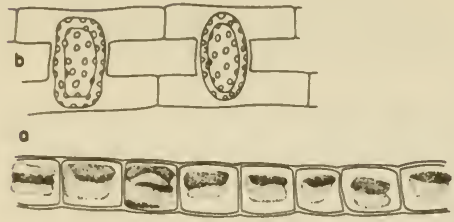

Figure 148

Fig. 148. Mougeotiopsis calospora Palla. $a$, vegetative cells with platelike chloroplast (without pyrenoid); b, zygospores.

There is only 1 species of this genus reported from the United States, and it is very rare. It is possible to make tentative identification of the species in the vegetative state because the chloroplast is much like that of Mougeotia, but without pyrenoids. The cells are characteristically very short cylindric. In reproduction it is similar to Debarya (Fig. 149) in that the entire contents of the conjugating cells become fused to form the zygospore.

208 b Chloroplasts with 2 to several pyrenoids

209a Filaments slender, mostly under $12 \mu$ in diameter (rarely as much as $30 \mu$ or $42 \mu$ ): chloroplast a parietal plate, usually not filling the cell; conjugating cells becoming filled with pectic substances: granular residues not found in the emptied reproductive cells: plants rare. Fig. $149 \ldots \ldots \ldots \ldots \ldots \ldots \ldots \ldots \ldots \ldots \ldots \ldots \ldots$

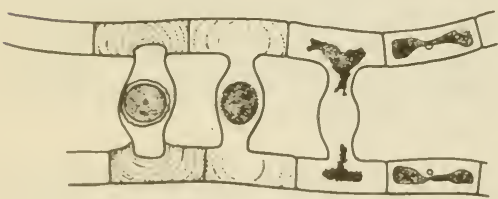

Figure 149

Fig. 149. Debarya sp., showing formation of zygospores and the lamellated substance deposited in the conjugating cells.

Species of Debarya are like some of the slender species of

Mougeotia and cannot be differentiated in the vegetative condition. Debarya is much less frequently found than Mougeotia. In reproduction all of the contents of the conjugating cells enter into the formation of the zygospore and the space once occupied by the protoplasts becomes filled with lamellated substance which is light refractive.

209b Filaments usually wider; chloroplast a broad, axial band with conspicuous pyrenoids, filling the cell laterally (in most species) but not in length: conjugating cells not filled with pectic substances; granular residues present in the emptied reproductive cells; plants common. See Fig. $145 \ldots \ldots \ldots \ldots \ldots$ MOUGEOTIA 
210 a (198) Plant a cluster of short, erect filaments (usually is branched but sometimes appears unbranched when young; some species form attached discs). Fig. $150 \ldots \ldots \ldots \ldots \ldots$. COLEOCHAETE
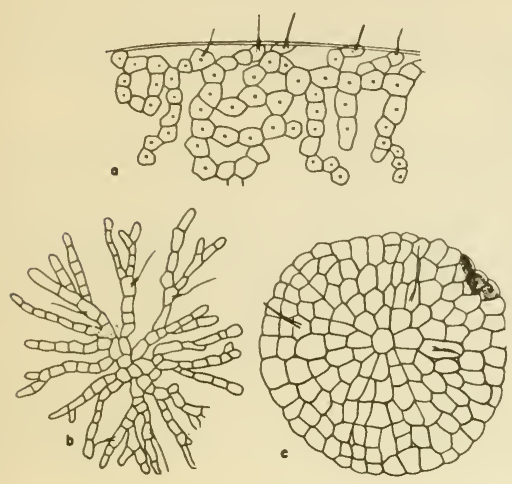

Figure 150

Fig. 150 a, Coleochaete Nitellarum Jost; b, C. soluta (Breb.) Pringsh.; c, C. orbicularis Pringsh.

There are 4 or 5 species of this genus which are commonly found in this country. They are differentiated by habit of growth (prostrate or in cushion-like tufts) and by size of cells. One species, C. Nitellarum Jost, occurs only in the walls of Nitella (Fig. 3) and is nearly always found wherever the host plant occurs. The endophyte shows especially well when Nitella is allowed to deteriorate in a laboratory container. The sheathed seta which characterizes Coleochate arises from a granule (the blepharoplast) within the cell and emerges through a pore in the wall. The disc-like thallus formed by some species of Coleochaete is frequently found on the sides of glass aquaria. In nature they occur on other algae or on submerged stems of cattail, or on submerged glass and crockery.

$210 \mathrm{~b}$ Plant not in the form of a cushion of erect filaments.......211

21la Thallus a macroscopic expanded sheet, one cell in thickness (usually in salt water, but occasionally found in brackish and fresh water); attached at one end. Fig. $151 \ldots$ MONOSTROMA

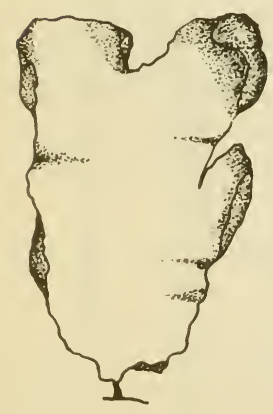

Fig. 151. Monostroma latissimum (Kuetz.) Wittr.

In salt water this genus includes species which form large thalli many centimeters long and wide, whereas in freshwater the plants are much smaller. Salt water species are sometimes carried inland and become distributed when oyster shells are thrown into freshwater habitats.

Figure 151

$21 \mathrm{lb}$ Thallus not a large, flat sheet, not so attached...........212 
212a Thallus an intestiniform, hollow tube, with the wall one cell in thickness. Fig. $152 \ldots \ldots \ldots \ldots \ldots \ldots \ldots$ ENTEROMORPHA

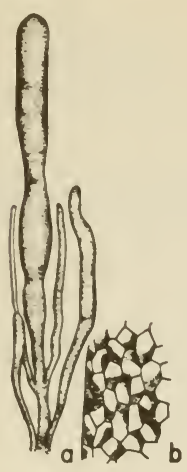

Figure 152

Fig. 152. Enteromorpha intestinalis (L.) Grev. a, habit of branched thallus; b, cells showing parietal position of chloro. plasts.

Like Monostroma (Fig. 151) Enteromorpha is primarily a marine alga but becomes adapted rather easily to freshwater habitats. The long, hollow tubes are frequently branched, forming slender threads or crinkled tubes. The plants are always attached to submerged plant stems, or to stones, especially in flowing water. There are eight species known from freshwater or brackish situations.

$212 \mathrm{~b}$ Thallus not an intestiniform tube.

$213 a$ Plant a lobed or ruffled disc of cells, $10 \mathrm{~cm}$. or less across; attached by a central short stipe (usually on rocks in alpine and arctic situations). Fig. $153 \ldots \ldots \ldots \ldots \ldots \ldots \ldots \ldots$ PRIOLA

Fig. 153. Prasiola crispa (Lightf.) Menegh. a, several forms of thallus; $b$, diagram to show

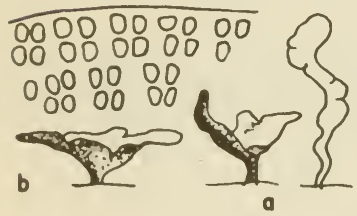

Figure 153 cells in 4's.

Four species of Prasiola have been reported from the United States, mostly from alpine and subalpine situations. In the Arctic the plants are common on soil rich in nitrogenous wastes. The thalli are foliose or frond-like sheets, attached at a central point by a short stalk or disc. The genus and Schizognium (Fig. 140), comprising the Schizogoniaceae, have star-shaped, axial chloroplasts.

213b Plant otherwise; a filament or a gelatinous strand.

214a A filament of cells.

214b $\AA$ gelatinous strand, or a tube, or a plant including a gelatinous tube which may or may not have cross partitions.......215 
215a Thallus a tube-like strand (sometimes forked), containing many lamellations (layers); cells at the tips of the tubes. Fig. 154... HORMOTILA

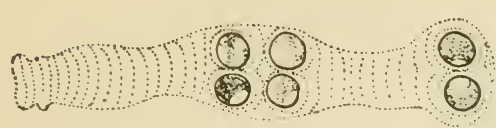

Figure 154

Fig. 154. Hormotila mucigena Borzi.

This curious plant is a branched colonial form by virtue of the fact that as the cells divide they secrete mucilage and construct gelatinous strands that branch and rebranch, the cells always occurring at the distal ends of the strands. The plant (one species only being known) is classed near Gloeocystis (Fig. 41) in the Tetrasporales (Palmellaceae).

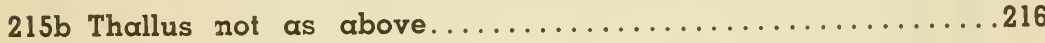

216a Cells located at the ends of undivided tubes, the cell bearing a seta with a sheathed base. See Fig. 62...CHAETOSPHAERIDIUM

216b Cells without setae.

217a Cells constricted in the middle, occurring at the ends of tubes which are united in colonies that are impregnated with lime. Fig. 155 OOCARDIUM

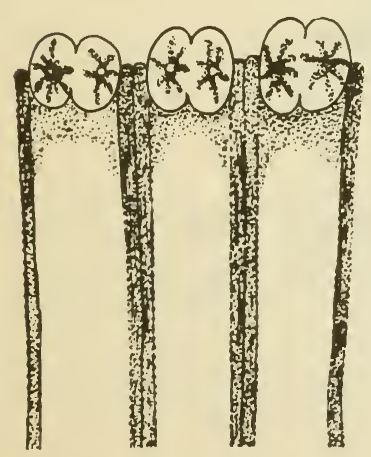

Fig. 155. Oocardium stratum Naeg.

This is a very rare desmid, or at least it has been reported but few times, probably because it is overlooked by collectors. The Cosmarium-like cells occur in colonies at the ends of branched gelatinous strands and are inclosed in a firm sheath of lime. They are to be sought on encrustations of rocks in dripping or flowing water.

Figure 155

217b Cells not constricted in the midregion, not arranged as above..218 
$218 \alpha$ Cells in tubes which are attached to microfauna. See Fig. 64. .COLACIUM

$218 \mathrm{~b}$ Cells not attached to microfauna.................... 219

219a Cells elongate-oval; brackish water or marine. Fig. $156 \ldots \ldots$. PRASINOCLADUS

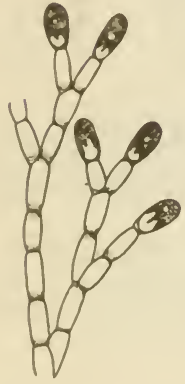

Figure 156

Fig. 156. Prasinocladus lubricus Kuck.

Although essentially marine this species has been known to occur in brackish water. It is an attached, branching tube composed of a series of compartments, forming a tree-like thallus, in which the oval protoplasts occur only at the tips of the branches. There is one chloroplast at the forward end of the cell which actually is the posterior pole because like some of its relatives (Malleochloris, Fig. 95) the cells are in an inverted position with the anterior end downward.

$219 \mathrm{~b}$ Cells round, not in brackish water habitats. .220

220 a Cells in 1 series or in several irregular series within simple or branched tubes; chloroplasts 2 laminate. See Fig. $45 \ldots \ldots$. . PALMODICTYON

$220 \mathrm{~b}$ Cells in several series, arranged in clusters of 4 in an irregularly shaped, elongate strand of mucilage; chloroplast 1, a parietal cup. See Fig. $35 . \ldots \ldots \ldots \ldots \ldots \ldots \ldots \ldots \ldots \ldots \ldots \ldots$ TETRASPORA 
221 (214) Filament of cells in 1 series, at least in the basal portion.

$221 \mathrm{~b}$ Filament of cells in more than 1 series, at least in the upper portion

222a Filament of cells in 1 series in the basal portion, of several series in the upper. Fig. $157 \ldots \ldots \ldots \ldots \ldots \ldots \ldots$. . . . . . .

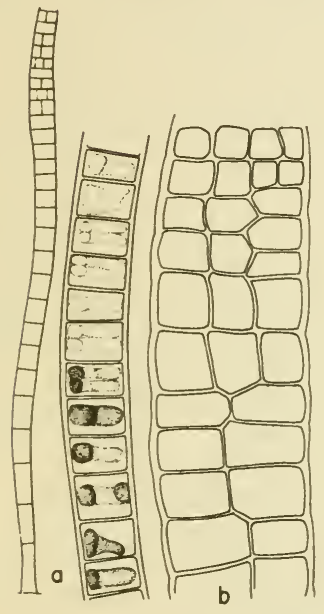

Figure 157
Fig. 157. Schizomeris Leibleinii Kuetz. $a$, base of filament and uniseriate portion; $b$, multiseriate upper portion of filament.

There is but 1 species in this genus, a plant which is uncommon but widely distributed over the world. The filaments are relatively large, when fully developed, and rather coarse. They occur in dark green clumps in standing water and have the macroscopic appearance of a growth of Spirogyra (Fig. 147) or of some large Ulothrix (Fig. 167), but unlike these genera, Schizomeris filaments separate easily and can be seen individually within the tuft. There is some evidence that the plant favors water rich in nitrogenous matter and is to be looked for in shallow water of lakes near the entrance of drains, effluent of sewage treatment plants, etc.

222b Filaments of cells in 1 series throughout.

.223

223a Chloroplast a parietal network, usually close and dense, covering the entire wall; pyrenoids many and conspicuous......224 
224a Cells cylindrical, usually many times their diameter in length (sometimes only 3 times longer than wide); wall thick. Fig. 158.

RHIZOCLONIUM

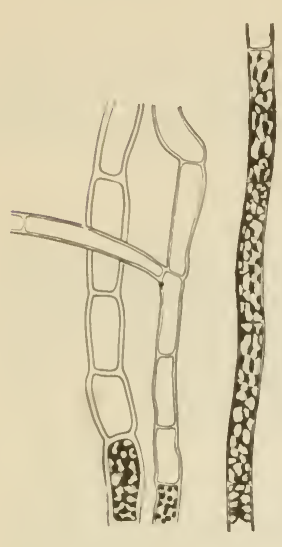

Figure 158

Fig. 158. Rhizoclonium Hookeri Kuetz.

The species belonging to this genus are all coarse, wiry, and but very little (if at all) branched. The filaments are composed of relatively long, cylindrical cells with thick walls which frequently show lamellations, especially near the cross walls. There are numerous chloroplasts, often compactly arranged and difficult of determination in respect to shape and organization. There are many pyrenoids. The branches are usually short and mostly at right angles to the main axis, but when they are long these plants intergrade with some forms of Cladophora (Fig. 192), in which the branching habit has been reduced. Rhizoclonium forms dense, tangled filamentous mats in standing water, or long, stringy, sometimes rope-like strands in flowing water. $R$. hieroglyphicum (Ag.) Kuetz. is the most common species, one which has rather uniformly cylindrical cells with relatively thin walls, and does not branch.

224b Cells not cylindrical, slightly larger at the anterior end, or even when appearing cylindrical always with at least 1 ring-like scar at the anterior end just below the cross wall. Fig. 159........

OEDOGONIUM

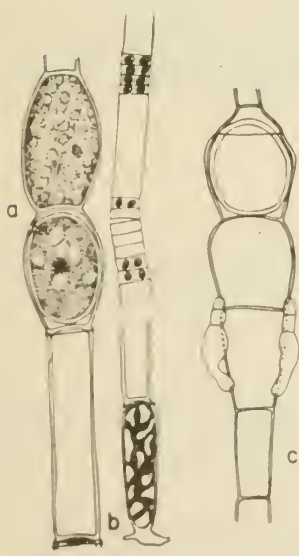

Figure 159

Fig. 159. a, Oedogonium crispum Kuetz., portion of filament with one fertilized and an unfertilized egg; b, basal hold-fast cell and portion of a filament containing antheridia and antherozoids; c, Oe. Westii Tiffany, showing dwarf male filaments epiphytic on the female plant.

There are over 250 species in this large genus which belongs to a family (Oedogoniaceae) in which there are only two other genera (Bulbochaete, Fig. 195; Oedocladium, Fig. 174). Species are differentiated by the size and morphology of the sexual reproductive organs and by the shape, decoration, and size of the mature zygospore (oospore). Whereas some species have the male organs (antheridia) in filaments the same size as the female, others possess dwarf male plants that grow as epiphytes on or near 
the female gametangium (oogonium). Oedogonium plants begin as attached filaments and may remain so throughout life, or they may become free-floating and form cottony masses near the surface, usually becoming pale yellow-green or cream-colored in age. Often these masses are so dense that if left to dry by the evaporation of water in which they are growing they form what is known as "algae paper."

$225 \alpha$ (223) Chloroplast a parietal plate, a ring, or a band which incompletely encircles the cell.....................226

225b Chloroplast massive and dense (difficult of determination), or a parietal sheet of thick and thin areas (padded appearance), or a branched, beaded thread (see Microspora). Fig. 1591/2.

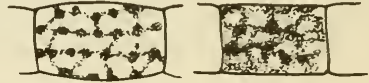

Figure $1591 / 2$

226a Filaments composed of long, cylindrical, multinucleate units; chloroplasts in the form of several parietal rings in each unit. Fig. $160 \ldots \ldots \ldots \ldots \ldots \ldots \ldots \ldots \ldots \ldots \ldots \ldots \ldots \ldots$ SPHAEROPLEA

a

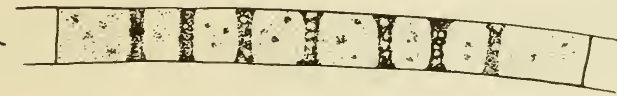

b

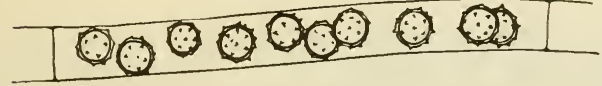

Figure 160

Fig. 160. Sphaeroplea annulina (Roth) Ag.; $\alpha$, vegetative cell with ring-like chloroplasts, and $b$, one cell containing fertilized eggs.

Two species of this genus are known from the United States, but $S$. annulina is the one most frequently seen, although it actually is a rather rare plant. Wherever it occurs it is likely to be in abundance. The characteristic long, cylindrical 'cells' may be mistaken for species of Rhizoclonium (Fig. 158), especially in the examination of preserved material. It is to be expected in shallow water of marshes and in bays of lakes.

226b Filaments not composed of long, multinucleate units; chloroplasts otherwise, usually 1 in each cell.................227 
227a Filaments prostrate, creeping on larger filamentous algae. Fig. 161 APHANOCHAETE

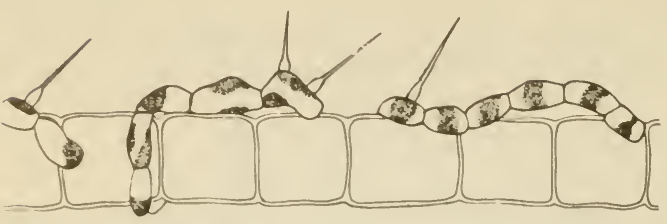

Figure 161

Fig. 161. Aphanochaete repens A. Br.

There are 3 species of this genus which are very common but are often overlooked because of their small size and their habit of creeping on the walls of larger filamentous algae. The simple setae, with their swollen bases extending from the cell wall are helpful in making identification. $A$. polychaete (Hansg.) Fritsch is characterized by having several setae on each cell.

227b Filaments not creeping on algae; floating or if prostrate, with

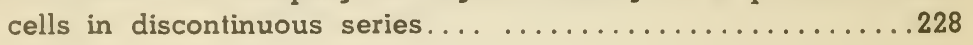

228a Filaments very short (up to 20 cells); often in interrupted series.

228b Filaments longer, in continuous series

229a Chloroplast a parietal plate extended over but a small part of the wall; usually subaerial. Fig. $162 \ldots \ldots \ldots$. STICHOCOCCUS

Fig. 162. Stichococcus ba-

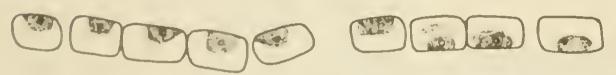

Figure 162 cillaris Naeg.

The difference between Stichococcus and the small filaments characteristic of Hormidium (Fig.

168 ) is difficult to define. In the former genus the filaments are usually relatively short (10 to 40 cells) and have a tendency to break into short segments intermittently. Of the 6 species which occur in the United States most are found on the bark of trees, old boards, or on damp soil. The species illustrated is the most common, often occurring with Protococcus on the moist bark of trees, the short filaments twisted and contorted, or coiled $i_{\Lambda}$ one plane. 
$229 \mathrm{~b}$ Chloroplast a broad plate extended over most of the cell wall; aquatic. Fig. 163.

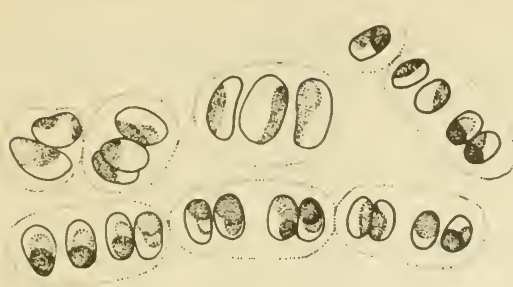

Figure 163

Fig. 163. Hormidiopsis ellipsoideum Pres.

This is the only species reported from this country and possibly cannot be differentiated from Hormidium (Fig. 168) except that the filaments are frequently interrupted and constricted at the joints, the cells being oblong or oval rather than cylindrical. Characteristically, the chloroplast extends but only part way around the cell wall.

230a Filament composed of units which include 2 oval or subspherical protoplasts; the space between protoplasts and the walls filled with layered (lamellose) material. Fig. 164......BINUCLEARIA
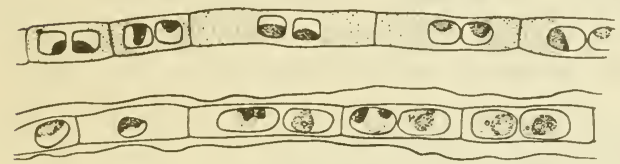

Figure 164

Fig. 164. Binuclearia tatrana Wittr., one filament showing a gelatinous sheath.

This is the only species reported from the United States; occurs intermingled with other filamentous algae, especially in mixtures taken from bogs. The paired protoplasts within each unit of the filament make it easy of identification.

$230 \mathrm{~b}$ Filaments of cells without paired protoplasts as above

23la Filaments with a gelatinous sheath

231b Filaments without a gelatinous sheath. .235

$232 \alpha$ Cells cylindric-quadrate, globose or ellipsoid; adjoined at the

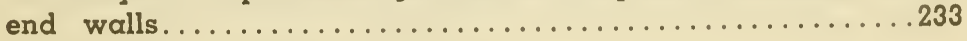


232b Cells oblong, not adjoined at the end walls. Fig. 165

a

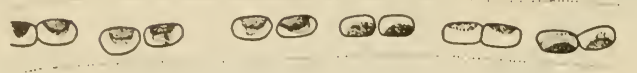

b

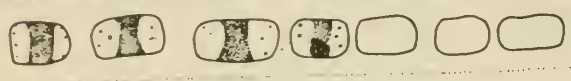

Figure 165

Fig. 165. a, Geminella interrupta (Turp.) Lag.; b, G. mutabilis ( $\mathrm{r}$ e b.) Wille.

These are filamentous plants which have cylindrical or broadly oval cells encased in a wide sheath of mucilage. The cells may be adjoined, or rather evenly spaced one-half to 2 cell lengths apart. Like Hormidium (Fig. 168) the chloroplast covers but a small portion of the wall.

$233 \alpha$ Cells quadrate or cylindrical; cell wall in 1 piece.......234

233b Cells globose, subglobose, or ellipsoid, wall usually of 2 overlapping pieces that meet in the midregion of the cell and form short lateral projections (resulting from $a$ rim about the cell in center). Fig. $166 \ldots \ldots \ldots \ldots \ldots \ldots \ldots \ldots \ldots \ldots$ RADIOFILUM

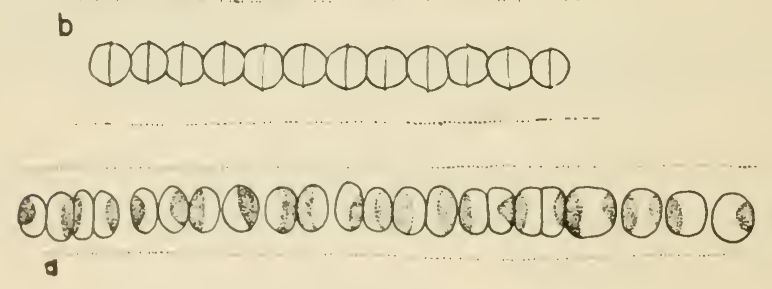

Figure 166

Fig. 166. a, Radiofilum flavescens G. S. West; b, R. conjunctivum Schmidle.

The globose or subglobose cells of these filaments help to separate them from Geminella (Fig. 165) which also possesses a gelatinous sheath. Some species ( $R$. conjunctivum Schm., e. g.) have the wall in 2 sections which form a rather conspicuous overlapping in the mid region. There are 3 species in this country, differentiated by shape and size of the cells. 
234a Chloroplast a parietal band or ring which encircles the cell or nearly so. Fig. $167 \ldots \ldots \ldots \ldots \ldots \ldots \ldots \ldots$ ULOTHRIX

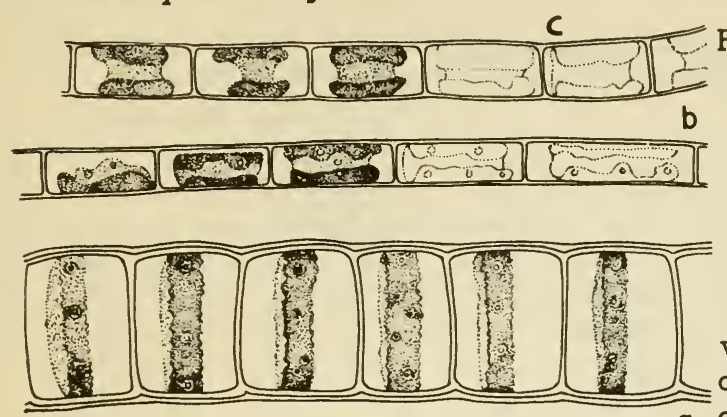

Fig. 167. a, Ulothrix zonata (W e b e r \& Mohr) Kuetz., with ring-like chloroplast; b, U. cylindricum Presc.; c. U. aequalis Kuetz.

Species of this genus vary greatly in size and proportions of the Figure 167 a cells. Some are shorter than wide, others distinctly cylindrical. The most familiar species, and the largest is U. zonata (Fig. 167a) which has a basal holdfast cell and chloroplasts which completely encircle the cell wall. Others have a chloroplast that forms two-thirds to three-fourths of a circle. Usually there are 1 or more conspicuous pyrenoids. Whereas most species occur in standing water, $U$. zonata may be found in streams and usually in rather cold habitats.

234b Chloroplast a laminate plate lying over a small portion of the wall and not encircling it. See Fig. $165 \ldots \ldots \ldots$. GEMINELLA

235a (231) Filaments not showing a basal-distal differentiation. Fig.

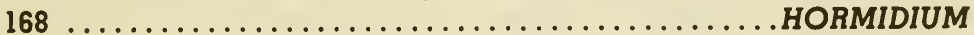

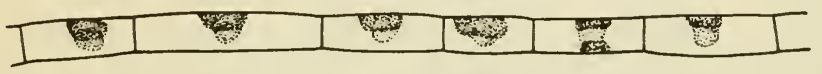

Figure 168

Fig. 168. Hormidium Klebsii G. M. Smith.

This genus includes several species of simple, unbranched filaments of cylindrical cells which are characterized by having chloroplasts which extend only part way around the cell and which are only about one-half the cell in length.

235b Filaments with a basal holdfast.................236 
236a Cells elongate-cylindric, the apical cell unsymmetrically pointed. Fig. $169 . \ldots \ldots \ldots \ldots \ldots \ldots \ldots \ldots \ldots \ldots \ldots \ldots \ldots \ldots \ldots$ URONEMA

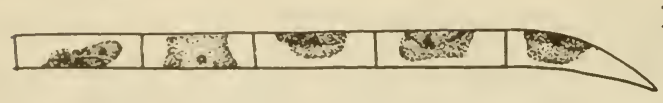

Fig. 169. Uronema elonga-

Figure 169 tum Hodgetts.

This is the only species in a genus of question. able position. The cells are long and cylindrical with a Ulothrix-like chloroplast. Usually the filament is only a few cells in length. The unsymmetrically pointed apical cell is the chief identifying character. Young stages in the development of Stigeoclonium plants should be kept in mind when identification of Uronema is made.

236b Cells short-cylindric, apical cell not tapering. See Fig. 167... ULOTHRIX

237a (225) Cells quadrate or oval to subglobose, inclosed in a stratified gelatinous sheath. Fig. $170 \ldots \ldots \ldots \ldots$ CYLINDROCAPSA

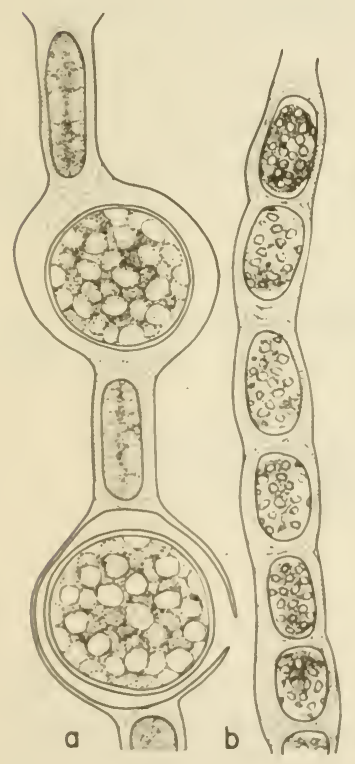

Figure 170
Fig. 170. Cylindrocapsa geminella var. minor Hansg. a, portion of filament with oogonia; $b$, vegetative cells.

Although filaments of this genus begin as attached plants they soon become free-floating and are found intermingled with other filamentous algae, especially in soft water or acid lakes. The chloroplasts are so dense and the cell contents include so much food storage material that few structural characteristics can be determined. The female reproductive organs are globular and greatly swollen, often red in color, as are the antheridia which occur as series (sometimes double) of smaller cells. 


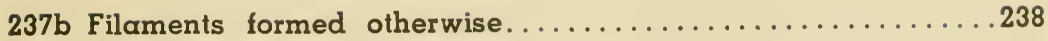

238a Cells orange or golden-red because of haematochrome; plants aerial on trees and rocks; chloroplast dense and indeterminate of shape. Fig. $171 \ldots \ldots \ldots \ldots \ldots \ldots \ldots \ldots$ TRENTEPOHLIA

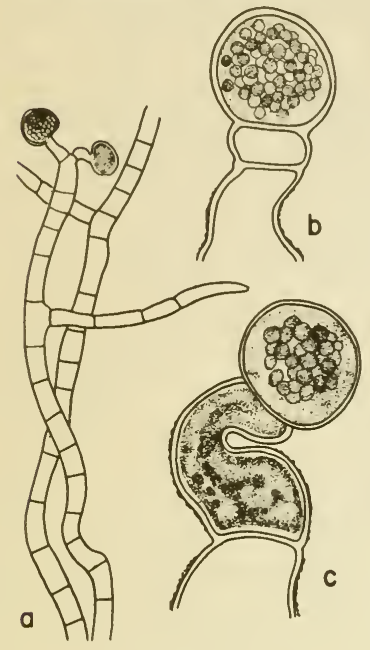

Figure 171

Fig. 171. Trentepohlia Iolithus (L.) Wallroth. $\alpha$, filament with 2 terminal sporangia; b, c, sporangia in detail.

This species and T. aurea Mart. are the 2 which are the most common of the 6 which have been reported from the United States. They grow on moist stones, dripping cliffs, and on the moist bark of trees. The characteristic orange color makes this plant conspicuous, especially when it forms extensive patches, sometimes forming a felty-mat over large areas of rocky cliffs. In southern United States the moist sides of trees throughout large areas of the countryside are colored reddish by these algae. In humid situations of the tropics and subtropics the filaments become infested with a fungus to form the lichen, Coenogonium. The haematochrome pigment appears in the cell as a reaction to intense illumination.

238b Cells without haematochrome; plants aquatic; chloroplast a perforated and padded sheet or a branched, beaded ribbon. Fig.

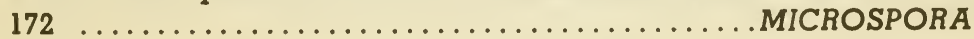

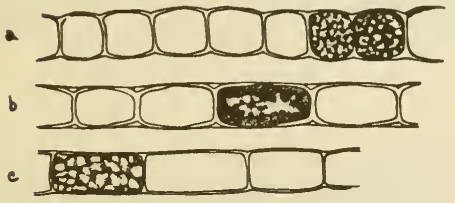

Figure 172

Fig. 172. $\alpha$, Microspora Loefgrenii (Nordst.) Lag.; b, M. Willeana Lag.; c, M. floccosa (Vauch.) Thur.

In this genus the simple, unbranched filaments have chloroplasts that vary greatly in respect to the degree with which they cover the wall. There are 5 or 6 species, differentiated by cell size and proportions, and by thickness of the wall. Some species show the 2-parted character of the wall, especially at the ends of the filaments where the line of separation having occurred in the midregion of the cell rather than at the juncture of 2 cells, forms characteristic $\mathrm{H}$-shaped pieces. 
239a (221) Plants macroscopic; embedded in soft mucilage; a main axis with whorls of branches giving the thallus a beaded effect that is visible to the unaided eye. Eig. 173...BATRACHOSPERMUM

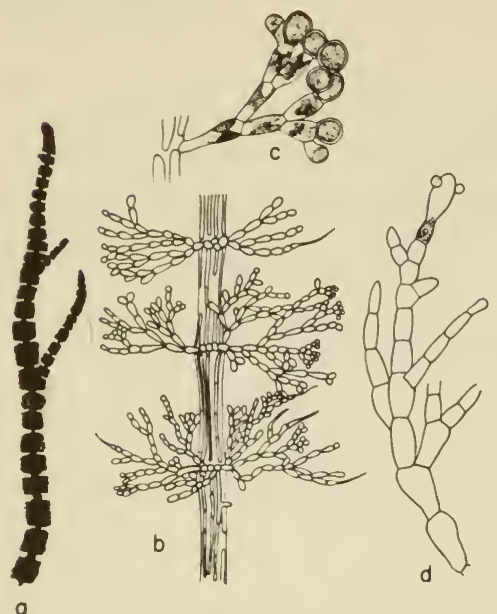

Figure 173

Fig. 173. a, Batrachospermum moniliforme Roth, habit of plant; $\mathrm{b}$, portion of thallus showing small antheridial cells at tips of branches; C, B. vagum (Roth) Ag., antheridial branch in detail; d, B. Boryanum Sirod., carpogonial branch with 2 male cells attached to trichogyne of the carpogonium (female organ).

This genus belongs to the red algae (Rhodophyta) although it shows none of the red color characteristic of this group of algae as they occur in the ocean. The macroscopic thalli, highly branched and beaded in appearance, encased in copious mucilage make these plants easily identified. The thallus may be gray-green or bluegreen, or olive in color. B. vagum is perhaps the most common species in this country, often occurring in large patches over stones in flowing water. Some species prefer quiet water and are to be sought in Sphagnum bog pools. Microscopically it is one of the finest appearing genera of fresh water algae.

$239 \mathrm{~b}$ Plants microscopic, or if macroscopic, not showing whorls of

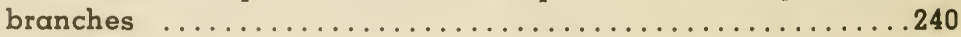

240 $\alpha$ Filaments uniseriate below, becoming multiseriate above with cells brick-like in shape and arrangement; cells adjoined. See

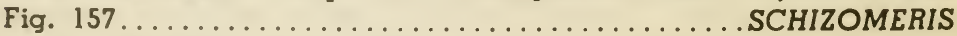

$240 \mathrm{~b}$ Filaments multiseriate throughout; cells not adjoined but arranged in irregular linear series within a gelatinous strand to form a false filament. See Fig. $45 \ldots \ldots \ldots \ldots \ldots$. PALMODICTYON 
24 la (189) Plants composed of cells or of cellular units; cross walls

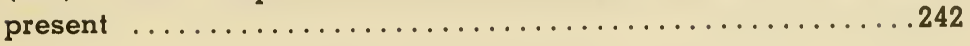

241b Plants multinucleate filaments (coenocytes), without cross walls (except when reproductive structures are developed and separated by a cross partition from the main filament)............281

242a Plants growing on moist soil with rhizoidal branches composed of long, narrow cells; apical cell usually with a cap (thimble). Fig. $174 \ldots \ldots \ldots \ldots \ldots \ldots \ldots \ldots \ldots \ldots \ldots \ldots \ldots \ldots \ldots \ldots$ OEDOADIUM

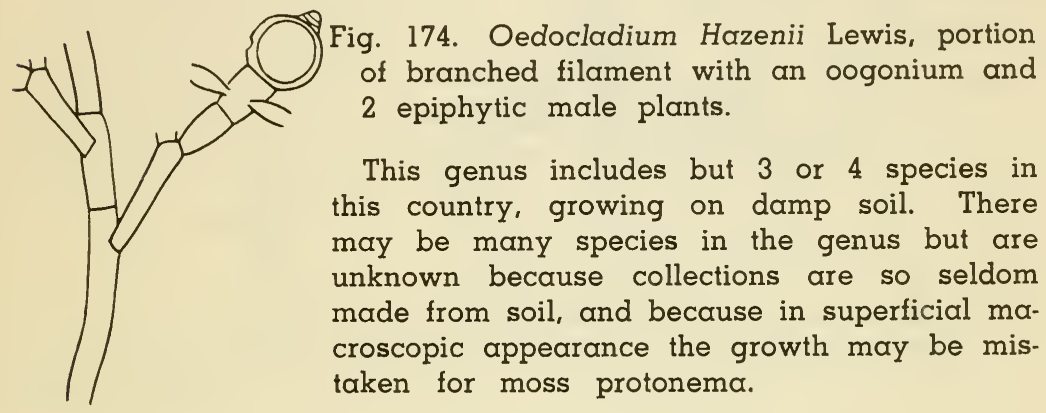

Figure 174

242b Plants aquatic; parasitic on higher plants, or if terrestrial, without long narrow rhizoidal branches and without terminal cap...243

243a Plants prostrate, growing horizontally; mostly epiphytic or endophytic; upright branches sometimes lacking; forming discs or flat expansions .244

243b Plants not growing entirely prostrate, at least in part with erect branches; free-floating, parasitic on higher plants, or perforating

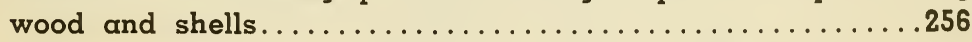

244a Thallus a freely-branched filament; cells usually bearing setae or hairs.......................................

244b Thallus not freely-branched but forming a disc or flat expansion of cells; sometimes forming a false cushion (pseudoparenchymatous) 
$245 a$ Endophytic in walls of other algae.................... 246

245b Not endophytic in walls of other algae..............247

246a Cells bearing setae which are sheathed at the base. See Fig. 150. .COLEOCHAETE

246b Cells not bearing setae. Fig. 175

ENTOCLADIA

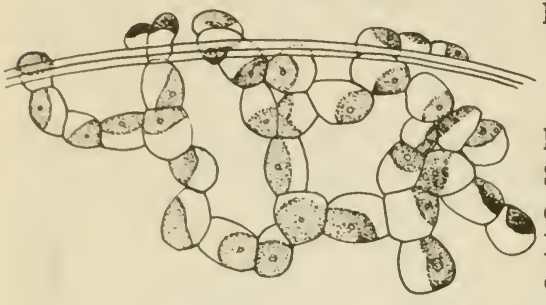

Figure 175

Fig. 175. Entocladia polymorpha (G. S. West) G. M. Smith.

This genus includes only 2 known species in the United States. Although probably very common it is easily overlooked because the thalli are small and grow inconspicuously within the walls of larger algae.

247a (245) Some cell walls bearing setae with a sheathed base; terminal cells of branches not tapering to form hairs. See Fig. 150..... . COLEOCHAETE

$247 \mathrm{~b}$ Cells with setae that are not sheathed at the base, or if without, ends of branches tapering to form hairs.............. 248

248a Setae and terminal hairs multicellular

249a Multicellular setae arising from lateral walls of the cells. Fig. 176. PSEUDOCHAETE

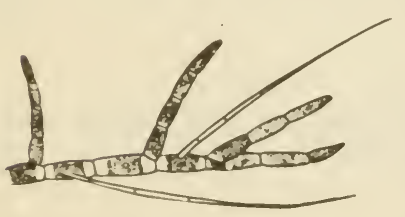

Figure 176

Fig. 176. Pseudochaete gracilis West \& West.

This species is rarely found, growing partly prostrate, partly erect on submerged plants or other substrates. The branched filaments taper at both ends. Some of the lateral branches form long, narrow and finely tapering hairs. Some authorities regard Pseudochaete as a form of Stigeoclonium. See Fig. 177. 
249b Multicellular hairs resulting from the apical tapering of branches. Fig. $177 \ldots \ldots \ldots \ldots \ldots \ldots \ldots \ldots \ldots$. . . . . . . . . .

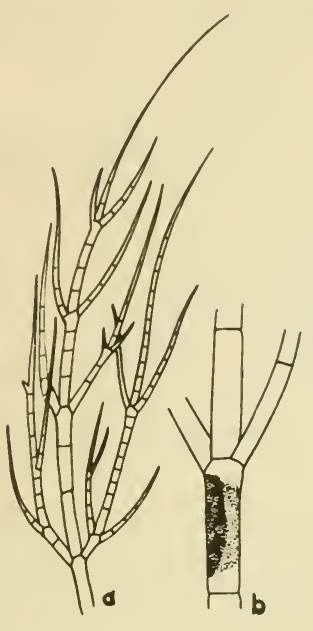

Figure 177
Fig. 177. $a$, Stigeoclonium flagelliferum Kuetz.; b, cell showing laminate chloroplast and pyrenoid.

There are several species of this genus which are differentiated by size, by order of branching and by the morphology of the thallus as a whole, some forming long, graceful tufts, others more bunched growths, with part of the thallus prostrate.

250a Growing in the mucilage of other algae. Fig. 178...CHAETONEMA

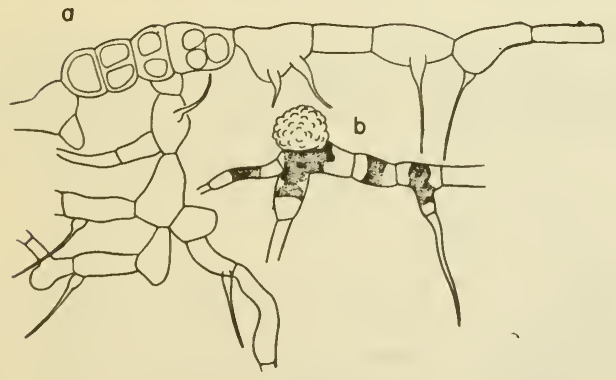

Figure 178

Fig. 178. Chaetonema irregulare Nowak. a, branches containing antheridial cells; b, oogonium.

There is only 1 species of this genus known, rather rarely seen because its habitat is the gelatinous matrix of highly branched algae such as Chaetophora (Fig. 196).

$250 \mathrm{~b}$ Growing or creeping on the walls of larger algae. See Fig. 161. APHANOCHAETE 
25la (244) Cells bearing setae with sheathed bases. See Fig. 150. . COLEOCHAETE

$251 \mathrm{~b}$ Cells without setae, or if setae present, without sheathed bases.252

252a Endophytic in the walls of other algae. See Fig. 175

ENTOCLADIA

$252 \mathrm{~b}$ Not endophytic in the walls of other algae

253a Some cells bearing setae.

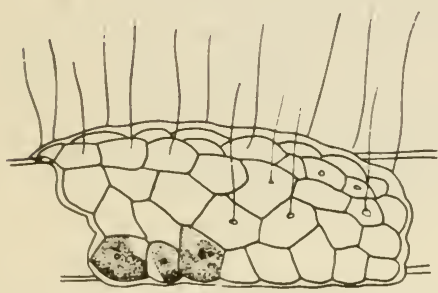

Figure 179
Fig. 179. Chaetopeltis orbicularis Berth.

This plant forms relatively small circular discs composed of indistinctly radiating filaments closely grown together side by side. It should be compared with Coleochaete (Fig. 156). Almost every cell in the thallus bears a long, very slender, hairlike seta.

253b Setae lacking

$254 \alpha$ Thallus $\alpha$ thin expansion, 1 cell in thickness; a circular disc or a somewhat irregular expansion. Fig. $180 \ldots \ldots$ PROTODERMA

Fig. 180. Protoderma viride Kuetz.

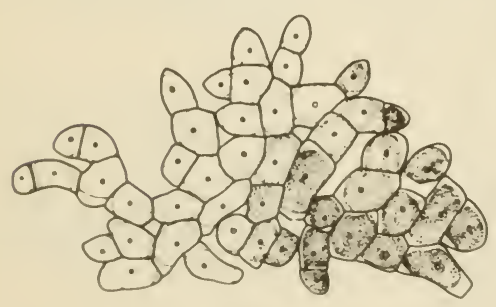

Figure 180
This prostrate plant forms a cushion-like thallus 1 cell in thickness at the margin and one which shows very irregular branching of short filaments. It is to be found growing on the stems of submerged aquatic plants.

254b Thallus cushion-like, several cells in thickness. .255 
255a Cells with several chloroplasts: thallus inclosed in a mucilaginous sheath. Fig. $181 \ldots \ldots \ldots \ldots \ldots \ldots \ldots$. . . . . . .

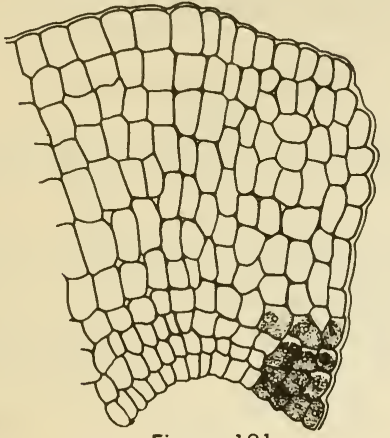

Figure 181

Fig. 181. Pseudoulvella americana (Snow) Wille.

The prostrate disc-like thalli of this plant are relatively large, 1 cell in thickness at the margin, several cells thick near the center. The entire plant is covered by a gelatinous film through which an occasional seta projects from the cell walls, but these are rarely found.

255b Cells with 1 reticulate chloroplast; thallus not inclosed in a sheath.

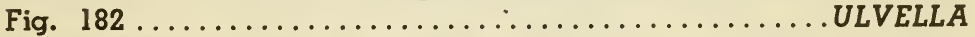

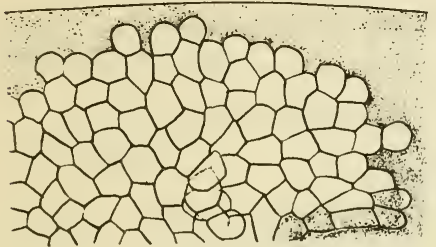

Figure 182

Fig. 182. Ulvella involens (Savi) Schmidle (Dermatophyton), diagram of attached colony showing arrangement of cells.

This plant forms irregular disc-like or cushion-like growths which are several cells in thickness when mature. They grow on submerged aquatic plants, sometimes on animals; do not possess setae.

256a (243) Plants parasitizing leaves of terrestrial Angiosperms (magnolia, tea, etc.). Fig. 183.................. EEPHALEUROS

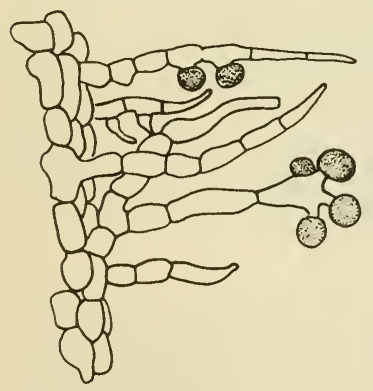

Figure 183

Fig. 183. Cephaleuros virescens Kunze, diagram of thallus as it grows under leaf epidermis of host plant, with erect branches bearing sporangia.

This species occurs in tropical and subtropical parts of the world, especially in areas where there is an optimum humidity so that the leaves of the plants on which the alga is parasitic are moist. The host may be Magnolia, tea (Thea), citrus trees, or Rhododendron. Because of the discoloration and degeneration of host tissue in the vicinity of the parasite some damage is caused by this alga and a certain amount of economic loss results, especially in tea plantations. Although the parasitized areas appear gray-green in color, the individual filaments of the cushion-like thallus of the alga are usually reddish because of the contained haematochrome pigment. 
256b Plants not parasitizing tissues of Angiosperms..........257

257a Cells without setae; filaments not tapering to hair-like tips...258

257b Cells bearing setae or with branches tapering to fine points. .276

258a Branches short, irregular and rhizoidal, often formed only near one end of the filament.............................. 59

258b Branches long, multicellular, usually forming a definite pattern of growth, opposite or alternate on the main axis........261

259a Chloroplast a spiral ribbon. See Fig. 147........SPIROGYRA

259b Chloroplast not a spiral ribbon....................... 260

260a Chloroplast an axial plate or band. See Fig. 145...MOUGEOTIA

$260 \mathrm{~b}$ Chloroplast a parietal network of thickenings and thin strands. See Fig. $158 \ldots \ldots \ldots \ldots \ldots \ldots \ldots \ldots \ldots \ldots$. RHIZOCLONIUM

26la Growing in wood, shells, or within limestone. Fig. 184.

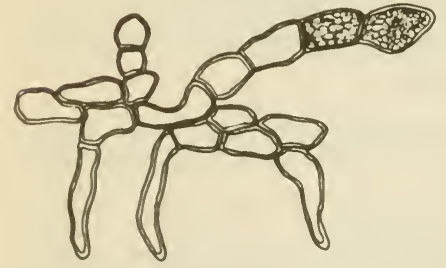

Figure 184 (sporangia) are borne on the upper part of the thallus or on the ends of short erect branches. Most species are marine.

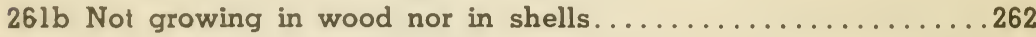

$262 \alpha$ Growing on trees or moist rocks; many or all cells showing an abundance of orange or reddish-yellow pigment (haematochrome). See Fig. $171 \ldots \ldots \ldots \ldots \ldots \ldots \ldots \ldots \ldots \ldots \ldots \ldots \ldots$ TRENTEPOHLIA

262b Plants growing elsewhere, not containing haematochrome ...263

$263 \alpha$ Thallus encrusted with lime........................... 264

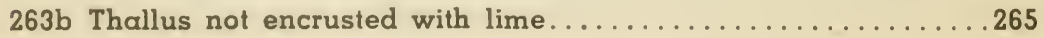


264a Thallus in the form of a cushion, giving rise to compactly arranged upright branches; cells broadest near the tip of the filaments; growing on wood or shells (sometimes on other plants). Fig. 185 .

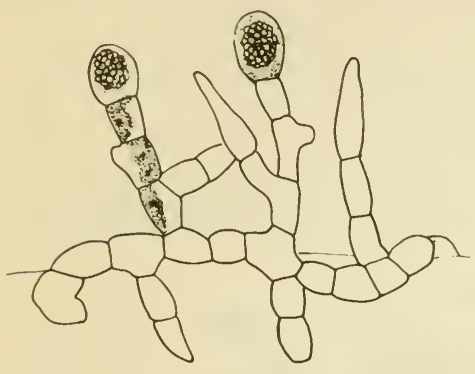

Figure 185

Fig. 185. Gongrosira Debaryana Rab., horizontal and e re ct branches with terminal sporangia. Like Gomontia (Fig. 184) these plants grow on shells and submerged wood, or on aquatic plants, but form external cushionlike masses (often encrusted with lime) rather than penetrating the substrate. The erect branched portion of the thallus is more extensively developed than in Gomontia. The chloroplast is parietal and usually more definite in outline than that of Gomontia which may be padded and irregularly netted.

264b Thallus composed of loosely branched filaments, the branches arising unilaterally. Fig. $186 \ldots \ldots \ldots \ldots \ldots$ CHLOROTYLIUM

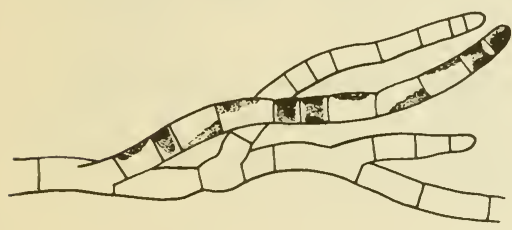

Figure 186

Fig. 186. Chlorotylium cataractum Kuetz., portion of plant showing characteristic habit of branch development.

The attached, lime-encrusted thalli of this branched filamentous plant are usually found in flowing water. The filaments present a distinctive appearance when seen microscopically because pairs of short, green cells (often with a reddish tinge) alternate with a more elongate and sometimes nearly colorless cell.

265a (263) Thallus in the form of a tuft of dichotomously branched, radiating, yellowish-green filaments. Fig. 187.....LEPTOSIRA

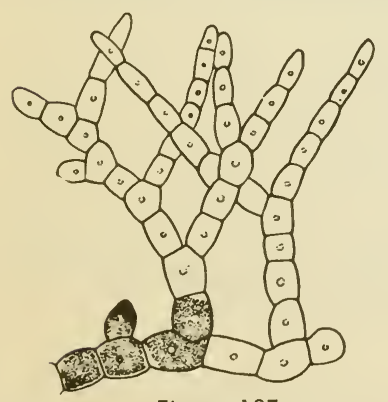

Figure 187

Fig. 187. Leptosira Mediciana Borzi, portion of plant showing horizontal and erect branching systems.

This species is known only from Massachusetts and Kentucky in this country. Filaments occur in yellowish tufts and are usually attached to subtrates in the water. The irregularly branched filaments of bead-like or barrel-shaped cells arising from a prostrate portion of the thallus help in making identification. 
$265 b$ Thallus not $a$ dense tuft of yellow-green filaments........266

266a Bearing enlarged, thick-walled akinetes (vegetative spores) among the cylindrical cells of the filament, or with spores at the ends

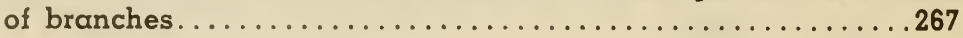

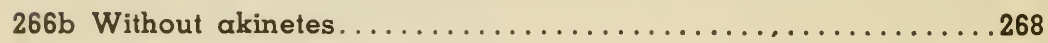

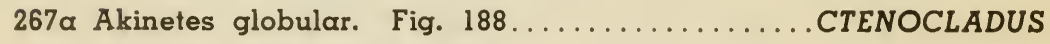

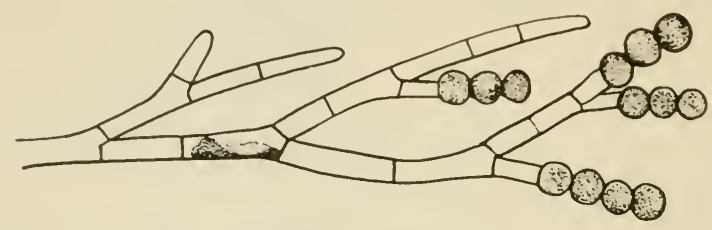

Figure 188

Fig.188. Ctenocladus circinnatus Borzi., showing a terminal series of akinetes.

This is a branched filamentous species, growing epiphytically on angiospermous plants in brackish water. The chains of globular akinetes at the ends of branches make it distinctive, although the habit of growth is somewhat like Gongrosira (Fig. 185).

267b Akinetes barrel-shaped or oval. Fig. 189.......PITHOPHORA Fig. 189. a, Pithophora Mooreana Collins; b, P. Oedogonia (Mont.) Wittr., showing a sample of the chloroplast.

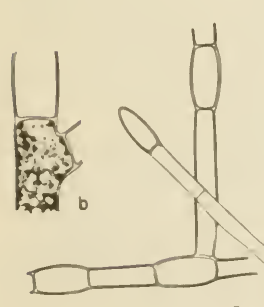

0

There are 3 or 4 species of this irregularly branched, filamentous genus in this country, differentiated by dimensions of the filament and by size and shape of the much-swollen akinetes that are formed intermittently throughout the plant. When occurring in laboratory aquaria, having been brought in on material obtained from biological supply houses, the filaments often fail to develop akinetes, the cells becoming exceedingly long and lose some of the appearance by which they are usually identified.

Figure 189 
268a (266) Growing on submerged wood and stones with a prostrate cushion-like mass of branches from which vertical branches arise. See Fig. $185 \ldots \ldots \ldots \ldots \ldots \ldots \ldots \ldots \ldots \ldots \ldots \ldots \ldots$ GONGROSIRA

268b Thallus formed differently..........................

269a Plants growing on shells of turtles; branching arising only from the base of the main filament. Fig. $190 \ldots \ldots \ldots$. BASICLADIA

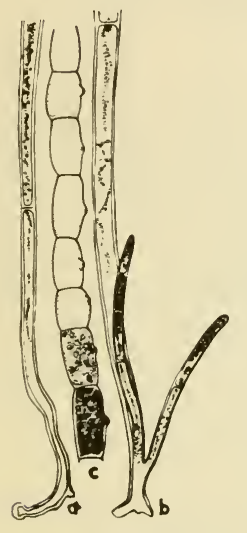

Figure 190

Fig. 190. Basicladia Chelonum (Collins) Hoffman \& Tilden. $a$, cells at base of filament; $b$, branching habit; $c$, series of sporangia formed in upper portion of filament.

This and 1 other species (differentiated mostly by size) comprise the genus which is distinctive in that the plants occur only on the shells of turtles, especially the snapper. Old turtles are usually "mossy" with the tufted growths of filaments which characteristically branch so close to the base that the branching habit is easily overlooked. Cells may be as much as $120 \mu$ in diameter but a millimeter or two in length.

$269 \mathrm{~b}$ Plant not growing on turtles, or with other types of branching. .270

270a Plants showing basal-distal differentiation, usually attached (floating in age); branching arbuscular (tree-like or bush-like).....271

270b Plants not forming bushy growths

27la Cells with haematochrome (reddish color in the chloroplasts). See Fig. $171 \ldots \ldots \ldots \ldots \ldots \ldots \ldots \ldots \ldots \ldots$ TRENTEPOHLIA 
272a Plants stout; walls thick and lamellate: chloroplast $\alpha$ dense reticulum with many pyrenoids........................ 273

$272 \mathrm{~b}$ Plants slender, very minute (not more than $5 \mu$ in diameter); wall thin: cross wall at the base of a branch above the level of origin from the main axis. Fig. 191

MICROTHAMNION

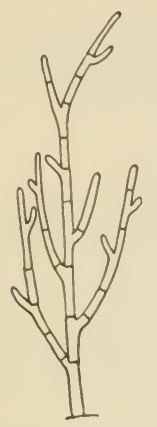

Fig. 19l. Microthamnion strictissimum Rab.

This species and its relative, $M$. Kuetzingianum Naeg. are easily overlooked in collections because the attached filaments are so minute and the chloroplast often so nearly colorless. They occur on larger filaments of other organisms but usually break away and are found floating free at maturity, intermingled with other algae.

Figure 191

273a Branching open and spreading; cells mostly cylindrical. Fig. 192. CLADOPHORA

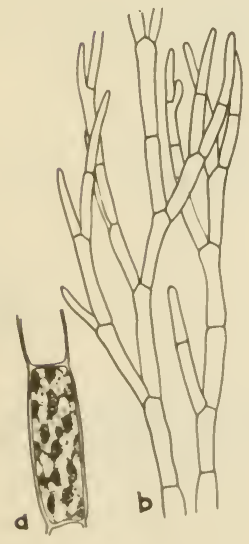

Figure 192
Fig. 192. Cladophora spp. $\alpha$, cell showing parietal, net-like or discontinous chloroplast; b, habit of branching.

There are numerous species of this genus both in fresh and in salt water. They are differentiated by size, shape of cell, and plan of branching. The habit of branching is variable according to habitat and species definitions, therefore, are poorly made. Some plants exist over winter in lakes and become wave-washed and lose their original appearance. Other species in lakes become free-floating and by wave action become rolled over and over with the result that "Cladophora-balls" are produced. These appear as densely branched and entangle 1 growths, with cells very irregular in shape. Perhaps the most characteristic habitat of Cladophora is on rocks in flowing water, especially on dams and waterfalls. 
273b Branching close and entangled, often dichotomous; downward projecting rhizoidal branches common; cells irregularly swollen. Fig. 193

AEGAGROPILA

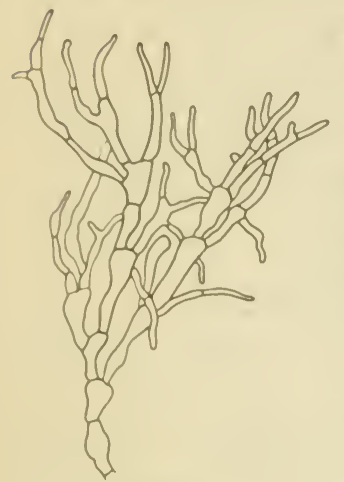

Figure 193

Fig. 193. Aegagropila profunda (Brand) Nordst.

This species is more irregularly branched than Cladophora and has downward directed rhizoidal branches. The upper filaments are densely entangled and the cells are more irregular in shape. As the species name suggests, it is found growing on the bottom of lakes at depths up to 200 feet (especially in clear water). Some authorities include Aegagropila under Cladophora.

274a (270) Vegetative cells very long and cylindrical, somewhat regularly interrupted by swollen, thick-walled cells (akinetes). See Fig. $189 \ldots \ldots \ldots \ldots \ldots \ldots \ldots \ldots \ldots \ldots \ldots \ldots \ldots \ldots \ldots$ PITHOPHORA

274b Akinetes lacking; cells all cylindrical or nearly so.......275 $275 a$ Branches scarce and short, or wanting altogether; if branches present, without repeated branching. See Fig. $158 \ldots \ldots \ldots \ldots$

275b Branches many-celled, bearing secondary branches which arise irregularly so that the arbuscular habit is almost lost. See Fig. 192; wave-washed and winter form of .......... CLADOPHORA

$276 a$ (257) Setae without cross walls at the base, formed by lateral extensions of cells just below the anterior cross parition of the cell.

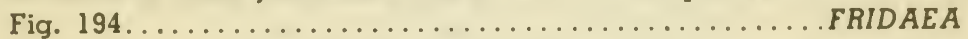

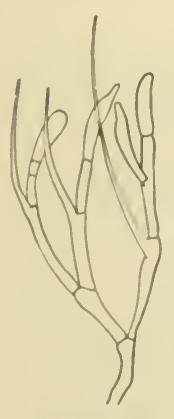

Fig. 194. Fridaea torrenticola Schmidle.

Figure 194

$276 \mathrm{~b}$ Setae formed otherwise. 
277a Setae bulb-like at the base. Fig. $195 \ldots \ldots \ldots \ldots$..... BULBOCHAETE

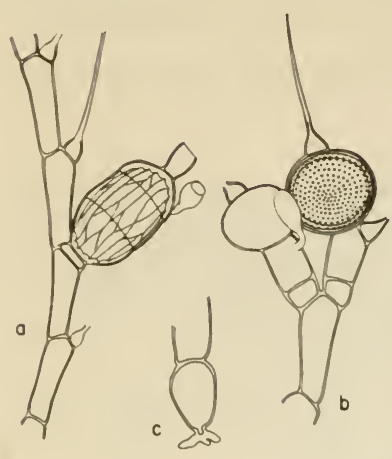

Figure 195

Fig. 195. $\alpha$, Bulbochaete insignis Pringsh., showing oogonium with oospore, and an attached dwarf male plant; b, B. congener Hirn; c, holdfast cell.

Like its close relative, Oedogonium (Fig. 159) this genus contains numerous species which are differentiated on the basis of dimensions and details of the reproductive structures. They cannot be identified in the vegetative condition. The branched filaments are always attached (at least when young) and are quickly identified by the bulbous-based, unicellular setae that develop at the anterior end of the cell. They are to be sought on overhanging grass, or on the culms of rushes, submerged aquatic plants, etc. Most species have dwarf male plants growing epiphytically on the oogania (female sex organs).

277b Setae shaped otherwise........................ 278

278a Setae sheathed at the base. See Fig. 150....... COLEOCHAETE $278 \mathrm{~b}$ Setae not sheathed at the base.......................

$279 \alpha$ Thallus not embedded in mucilage, or if so, inclosed in a very soft watery mucilage without definite shape..........280

$279 \mathrm{~b}$ Thallus inclosed in a firm mucilaginous matrix of definite shape, globular or somewhat elongate and irregularly arbuscular (sometimes strands $4-15 \mathrm{~cm}$. in length). Fig. 196.... CHAETOPHORA

Fig. 196. a, Chaetophora elegans (Roth)

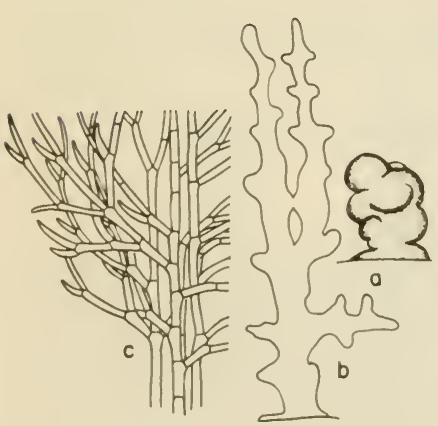

Figure 196

C. A. Ag., habit of thallus; b, C. incrassata (Huds.) Hazen, habit of thallus; c, C. incrassata, portion of branching system.

Microscopically, species of this genus are delicately and gracefully branched filaments that occur in macroscopic tufts or gelatinous balls. One, C. incrassata (Huds.) Hazen, is composed of cables of elongate cells which give off laterally dense tufts of dichotomous branches. The resulting growth produces bush-like or arbuscular thalli which may become 10-15 centimeters in length. Other species form spherical or irregularly globose balls one or two millimeters in diameter on submerged leaves (especially in cold water), wood, or on cattail stems and are often gregarious so that extensive patches occur. 
The firmness of the mucilage in which the plants are encased differentiates Chaetophora from its relatives Draparnaldia (Fig. 197) and Stigeoclonium (Fig. 177).

280a Thallus composed of slender, repeatedly branched filaments; cells all about the same size but tapering to fine points or hairs. See

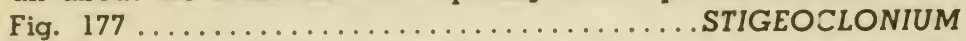

$280 \mathrm{~b}$ Thallus consisting of an axis of large cells from which arise tufts of branches composed of smaller cells; tufts in whorls, opposite or alternate, occurring at rather regular intervals. Fig. 197... DRAPARNALDIA*

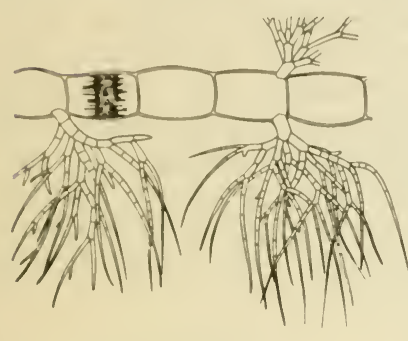

Figure 197

Fig. 197. Draparnaldia glomerata (Vauch.) Ag., showing tufts of lateral branches, with barrel-shaped axial cells containing band-like chloroplasts.

The genus is strikingly characterized by having a filament of large cells forming an axis from which tufted branches of smaller cells arise. Different species vary in size and shape of branching tufts. The thallus is inclosed in amorphous mucilage. Most species occur in cold water, often in shallow trickles or in springs. Macroscopically, they appear as pale green gelatinous strands that easily slip through the fingers.

28 la (241) Parasitic in higher plants such as Arisaema (Indian turnip).

\section{See Fig. 92.} PHYLLOSIPHON

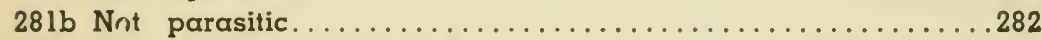

$282 \alpha$ Filaments repeatedly dichotomously branched, regularly constricted at the base of the forkings. Fig. 198...DICHOTOMOSIPHON

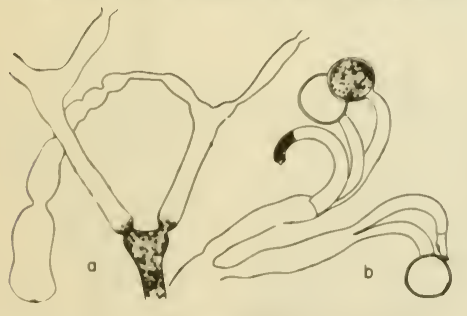

Figure 198 Fig. 198. Dichotomosiphon tuberosus (Braun) Ernst.

This species (the only one in the genus) occurs in dense, entangled tufts or mats, usually on the bottom of lakes, although occasionally on damp soil. There are downward growing, rhizoidal branches and upward directed vegetative and sex organ-producing branches. The oogonia when mature are so large that they can be easily seen with the naked eye. The plants seem to reproduce sexually only when growing in relatively shallow water (up to 4 feet) but may form extensive mats on the bottoms of lakes without fruiting in water up to 60 feet in depth.

*Draparnaldiopsis is a rare genus resembling Draparnaldia but differs essentially by having long and short cells in the main axis (alternating). Tufts of branches are given off by the short cells only. 
282b Filaments not dichotomously branched; without constrictions. Fig. 199 VAUCHERIA

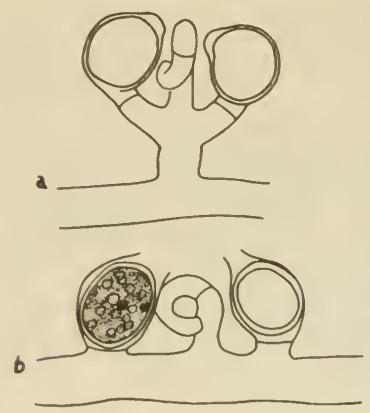

Figure 199

Fig. 199. a, Vaucheria geminata (Vauch.) De Cand., sex organs on a short pedicel; b, V. sessilis (Vauch.) De Cand.

Vaucheria usually forms dark green, velvety mats on damp soil, on rocks in flowing water, or occasionally wooly mats floating at the surface of ponds, having broken away from their substrate. At maturity the growths are 'dirty' green in color. The siphonous filaments are large enough to be seen individually with the unaided eye. Several species are common in fresh water, differentiated by shape and position of the sex organs. The mats of Vaucheria harbor a veritable zoological garden of small animals. Long considered to be a member of the Chlorophyta, this genus is now classed with the Xanthophyceae in the Chrysophyta.

283a (5) Chromatophores violet, gray-green or bluish-green, often appearing brownish in mass; mostly macroscopic Rhodophyta. 284

283b Chromatophores yellowish-green, carotin predominating, or some other color than above.......................290

284a Thallus macroscopic, spine-like, with node-like swellings, stiff and cartilaginous, very little if at all branched. Fig. 200..LEMANEA

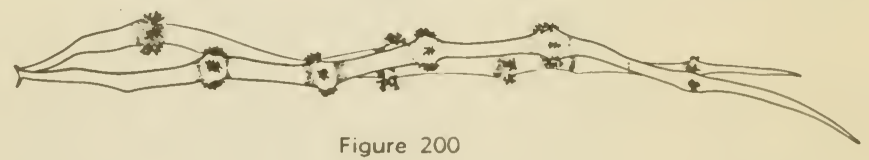

Fig. 200. Lemanea annulata Kuetz., habit of plant.

This genus is a member of the Rhodophyta, but like other fresh water red algae it is some other color, being gray- or olive-green. The thalli are cartilaginous and stand erect from an attached base. The slender, spine-like growths (up to $20 \mathrm{~cm}$. in length), devoid of branching make the plant easily recognizable. Species are differ. entiated mostly on details of the reproductive structures. 
285a Plant a uniseriate filament, branched or unbranched; (cells in 1

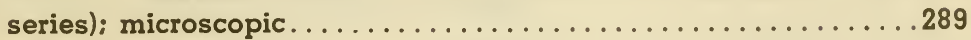

285b Plant a multiseriate filament or thallus; microscopic.......286

286a Thallus embedded in soft mucilage; consisting of an axial filament with cortical (overlying) cells, bearing whorls of short and usually densely clustered branches; nodes and internodes evident. See Fig. 173................BRATRACHOSPERMUM

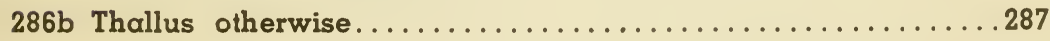

287a Thallus consisting of multiaxial filaments (strands of filaments) with numerous feathery branchings; without definite nodes and internodes. Fig. 201...................... THOREA

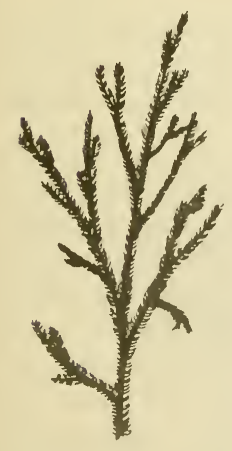

Figure 201

Fig. 201. Thorea ramossisima Bory.

This is a feathery thallus macroscopically; microscopically composed of a multiaxial cable of filaments with short, compactly arranged out-turned branches. They may be as much as $50 \mathrm{~cm}$. in length. It is of infrequent occurrence and sexual reproductive stages have not been found as yet.

287b Thallus otherwise 
288a Thallus multiaxial (cables of filaments) with closely compacted and appressed cortical cells; thallus branching irregularly in a dichotomous fashion. Fig. 202..............TUOMEYA

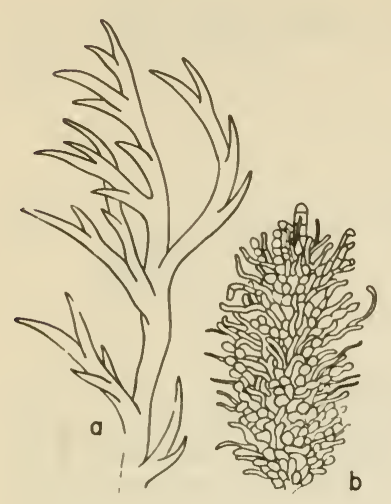

Figure 202
Fig. 202. Tuomeya fluviatilis Harvey. $\alpha$, habit of thallus; $b$, apical portion of branch.

This rather rigid and cartilaginous member of the Rhodophyta is identified by the complex dichotomous or antler-like habit of branching of the thallus which is com. posed of multiaxial series of filaments and corticating cells. There is but 1 species.

288b Thallus including a monaxial filament which is inclosed ared surrounded by compactly arranged and appressed, polygonal cortical cells which form just behind the apex. Fig. 203.

.COMPSOPOGON

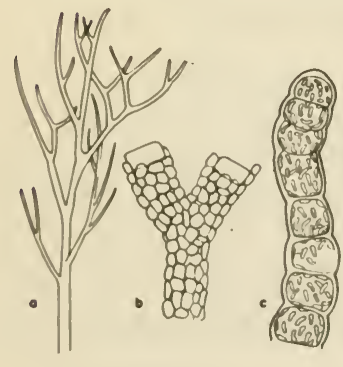

Figure 203

Fig. 203. Compsopogon sp., $\alpha$, habit of thallus; $b$, portion of axis showing corticating cells; c, apical portion of uncorticated branch showing chromatophores.

This is a member of the Rhodophyta which seldom occurs in entirely fresh water but is frequently found in brackish situations, attached to various substrates, but especially to submerged stems of woody plants such as mangrove. C. coeruleus (Balb.) Mont. is the most common species. Although essentially filamentous, the thallus is macroscopic in proportions and appears as a rather delicately branched, tufted or bushy growth, blueor gray- to violet-green in color. It is a tropical and subtropical genus but has been found occasionally in temperate latitudes. 
289a (285) Filaments attached, uniseriate, branched. Fig. 204 ...... . AUDOUINELLA

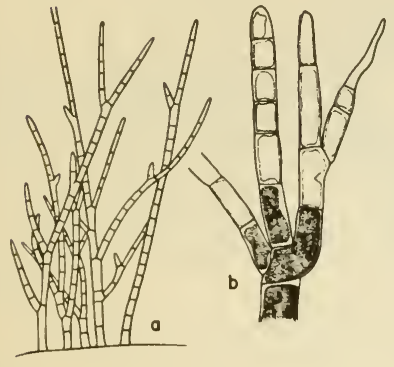

Figure 204

Fig. 204. Audouinella violacea (Kuetz.) Hamel. a, habit of thallus; b, branches in detail.

A member of the Rhodophyta, this species is nevertheless violet or graygreen. The loosely branched filaments are microscopic but may appear in tufts of macroscopic proportions. The main axial cells have disc-like or short ribbonlike chromatophores. In size, form, and habit of growth plants are easily mistaken for juvenile stages of Batrachosperum and if that genus is present in the habitat it could be assumed that Audouinella-like plants to be immature or so-called "Chantransia-stages" of Batrachospermum rather than Audouinella. There is but l species clearly defined in this country in fresh water and there is a disposition on the part of some authorities to classify it under the genus Acrochaetium which is mostly marine.

289b Filaments attached, uniseriate, unbranched. Fig. 205...BANGIA

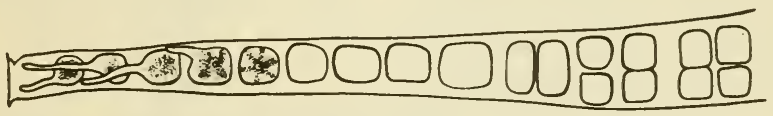

Figure 205

Fig. 205. Bangía fuscopurpurea (Dillw.) Lyngb., basal portion of filament.

This is a simple, unbranched member of the Rhodophyta, greenishred or purplish in color. Filaments occur in tufts, sometimes dense, attached to submerged stones and wood. Although most species of the genus occur in salt water, this one is known from brackish or even nearly fresh-water habitats. It may be expected in estuaries.

290a (283) Chromatophores yellow, yellow-brown, or dark golden-brown, rarely blue: plants motile or non-motile.............. 341 
29la Chromatophores pale yellow-green with xanthophyll predominating: iodine test for starch negative; cell contents often showing a metallic lustre. Phylum Chrysophyta. (This group of algae is often difficult of determination on the basis of color of the chromatophore alone inasmuch as the shades of green cannot be clearly distinguished from those of the Chlorophyta. In addition to the iodine test for starch (which ordinarily is confirmative) heating plants in concentrated sulphuric acid (when the specimens lend themselves to such treatment) provides a helpful differentiation. The yellow-green algae (Heterokontae or Xanthophyceae) become blue-green in the acid whereas Chlorophyta remain unchanged

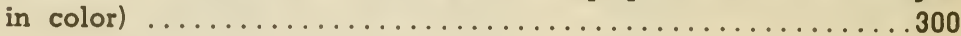

$291 \mathrm{~b}$ Chromatophores not yellow-green . . . . . . . . . . . . 292

$292 \alpha$ Cells with blue protoplasts or chromatophores..........293

292b Cells with protoplasts or chromatophores not blue........295

$293 \alpha$ One to four spherical or oval cells in a mucilaginous sheath which bears a gelatinous bristle. Fig. 206..........GLOEOCHAETE

Fig. 206. Gloeochaete Wittrockiana Lag.

This is an anomalous

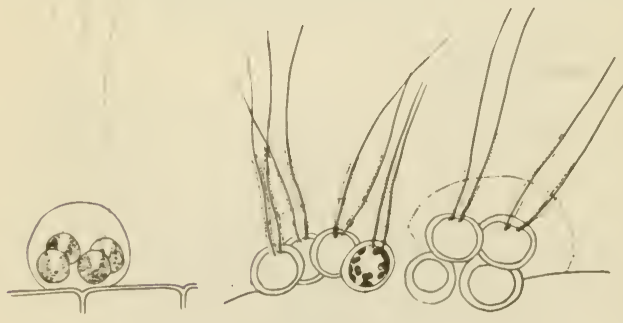

Figure 206 organism, the morphology and physiology of which is interpreted as one of symbiotism involving a colorless member of the Tetraspora family (Figs. 35, 48) and a bluegreen or cyanophyceous endophyte. The protoplast is a parietal cup similar to the chloroplast of many of the green algae. The long, slender gelatinous hairs make this species easy of identification. Cells occur in clumps (rarely solitary) attached to filamentous algae.

293b Plants not as above; sheaths present or absent although cells may be inclosed by old mother cell wall................294 
294a A linear series of globular or oblong cells within a gelatinous matrix, chromatophores star-shaped. Fig. 207...ASTEROCYSTIS

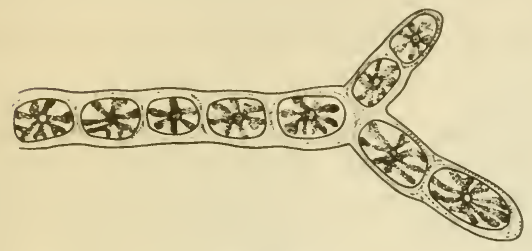

Figure 207

Fig. 207. Asterocystis smaragdina (Reinsch) Forti.

The bright blue-green, starshaped chromatophores of this species (the globose or oval cells being enclosed in a wide gelatinous sheath) help to identify this branched filamentous alga. It is a member of the Rhodophyta; usually occurs as an epiphyte on larger filamentous algae but may appear in mixtures of free-floating forms.

294b Two to four, or eight globose or oval cells contained within an enlarged mother-cell wall; chromatophore-like bodies vermiform (few and long, or many and short). Fig. 208....GLAUCOCYSTIS
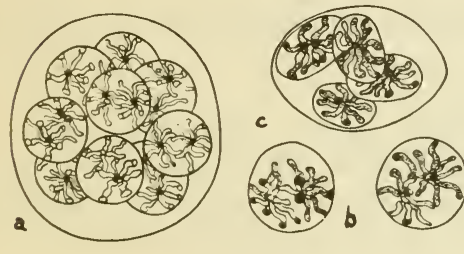

Figure 208

Fig. 208. $a, b$, Glaucocystis duplex Presc.; c, G. Nostochinearum Itz.

There are apparently 2 or 3 species of this genus which like Gloeochaete (Fig. 206) involve an endophytic blue-green alga and $\alpha$ colorless member of the Oocystaceae (Fig. 85). The protoplasts are bright blue-green and occur in different shapes and arrangements within either globose or oval cells, according to species. The plants are free-floating in the tychoplankton near shore or in shallow water habitats of swamps and bogs.

295a (292) Cells in compact, irregularly shaped colonies, appearing brown or orange-colored because of dark mucilage. See Fig.

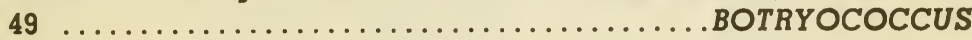

295b Cells not in opaque or orange-colored colonies as above; contents red, violet-red, or green with a red tinge.............296

$296 \alpha$ Living in snow in alpine regions (red snow). See Fig. $57 \ldots \ldots \ldots$ CHLAMYDOMONAS

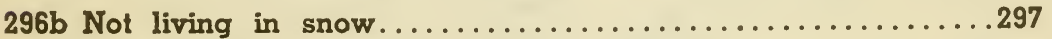

297a A colony of oval or globose cells inclosed in a layered sheath. See Fig. $41 \ldots \ldots \ldots \ldots \ldots \ldots \ldots \ldots \ldots \ldots$. . . . . . . . . .

297b Cells not in colonies; sheath not layered.............298 
298a Cells spherical, solitary or gregarious, terrestrial, forming dark red patches on damp soil (common in green houses). Fig. 209.

PORPHYRIDIUM

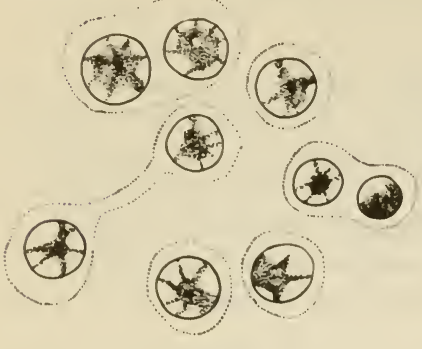

Fig. 209. Porphyridium cruentum Naeg.

Figure 209

298b Cells round, ellipsoid, or fusiform, not arranged as above...299

299a Cells fusiform; haematochrome coloring the green cell red; with 1 flagellum. See Fig. $8 \ldots \ldots \ldots \ldots \ldots \ldots \ldots \ldots$ EUGLENA

299b Cells round or ellipsoid; protoplast with a wide wall which appears as a gelatinous sheath; flagella 2, but usually not showing when cells are in an encysted condition at which time they exhibit a red color. See Fig. 19............ HAEMATOCOCCUS

300a (291) Plants filamentous.............................

$300 \mathrm{~b}$ Plants not filamentous.

30 la A false filament, consisting of branched tubes with 1 or 2 spherical cells at the distal ends. Fig. $210 \ldots \ldots \ldots \ldots$ MISCHOCOCCUS

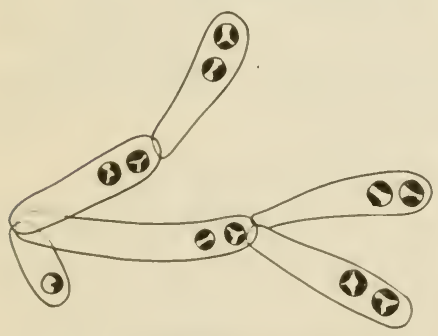

Figure 210

Fig. 210. Mischococcus confervicola Naeg.

The globose, yellowish-green cells of this species occur at the ends of repeatedly branched gelatinous stalks, attached to filamentous algae. Only 1 species is known from this country.

$30 \mathrm{lb}$ Plant a true filament. .302 


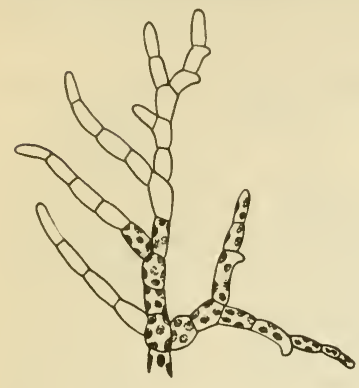

Fig. 211. Monocilia viridis Gerneck.

This and another species, $M$. flavescens Gerneck, are the only ones reported from this country, the former being more common. It occurs as an irregularly and indefinitely branched filament in soil. $A$ member of the Chrysophyta, the disc-like chromatophores are yellow-green or yellow in color, and the food reserve is in the form of oil; starch test negative.

Figure 211

$302 \mathrm{~b}$ Filament not branched.

303a Cells long-cylindrical; wall of cells formed of 2 pieces which overlap at the midregion, the overlapping usually evident when empty cells are viewed; filaments showing H-shaped pieces upon fragmenting; cells often with lateral walls convex. Fig. $212 \ldots \ldots \ldots$

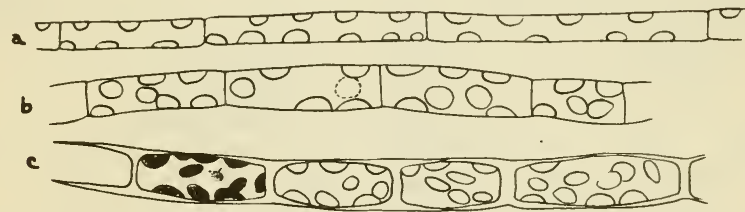

Figure 212

Fig. 212. a, Tribonema bombycinum var. tenue Hazen; b, T. bombycinum (Ag.) Derbes \& Solier; c, T. utriculosum (Kuetz.) Hazen.

There are 3 or 4 species of this simple, unbranched filamentous member of the Chrysophyta, differentiated by proportions of the cell and number and shape of the chromatophores. Like Microspora (Fig. 172) in the Chlorophyta, the cell walls are composed of 2 sections which adjoin and overlap in the midregion of the cell. Hence when the filaments fragment the typical H-shaped sections are seen. By careful focusing the overlapping of the wall sections can be seen in the unfragmented portions of the filament, especially in some species which have a relatively thick wall. The chromatophores are pale-green or yellowish and nccur as parietal discs. 
303b Cells short-cylindric or quadrate: overlapping of wall sections not apparent but visible at the end of broken filaments; lateral margins of cells strictly parallel. Fig. $213 \ldots \ldots \ldots \ldots$ BUMILLERIA

Fig. 213. Bumilleria sicu-

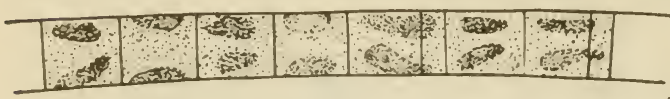

Figure 213

There are 2 species known from the country, $B$. exilis Klebs being much smaller $(6 \mu$ in diameter)

than the one figured. The unbranched filaments are similar to Tribonema (Fig. 212) but the cells are more nearly rectangular in optical section, with parallel lateral walls. Sometimes external overlapping H-shaped sections of thicker wall layers, brownish in color, occur intermittently along the filament.

304a (300) Plant a small (1-2 mm. diam.) green vesicle, balloon-shaped; terrestrial. Fig. $214 \ldots \ldots \ldots \ldots \ldots \ldots \ldots \ldots$. . . . . . . .

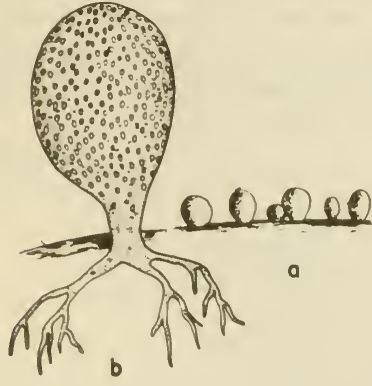

Figure 214

Fig. 214. Botrydium granulatum (L.) Grev.

On damp soil under green house benches or on mud of lakes where water has receded tiny green, balloon-like growths appear. These are siphonaceous members of the Chrysophyta which have underground rhizoidal branches in which resting spores may be found. Plants can be seen with the unaided eye or are easily detected with a hand lens. Although dark green in color the plant has other characters which relate it to the yellow-green algae, such as the absence of starch and the possession of zoospores with flagella of unequul length. There is another species, B. Wallrothii Kuetz., which has a thick, wrinkled, lamellate wall.

$304 b$ Plant not a green vesicle: aquatic.................... 305

$305 a$ Cells solitary or incidentally clustered............... 306

$305 \mathrm{~b}$ Cells in colonies, definite or indefinite in shape and arrangement; sometimes forming stalked colonies.............. 333

306a Cells attached, sessile, or on a stalk................ 307

306b Cells free-floating or swimming.................... 314

307 a Cells sessile. . . . . . . . . . . . . . . . . . . . 308

$307 \mathrm{~b}$ Cells on $a$ short or long stalk..................... 310 
$308 a$ Cell membrane in 2 sections, the upper lifting off at maturity to allow escape of aplanospores (small globular spores); cells oval or short-cylindric. Fig. $215 \ldots \ldots \ldots \ldots \ldots$. . . . . .

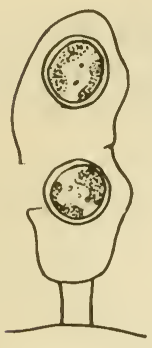

Fig. 215. Chlorothecium Pirottae Borzi.

This cylindrical plant with parietal yellow-green chromatophores is attached by a short stalk and a disc to submerged plants, including larger algae. It is rather rare (only one species reported from this country) and is easily overlooked because it occurs in the dense mixture of algae from bogs.

Figure 215

308b Cell membrane not in 2 sections...................... 309 $309 a$ Cells globose or subglobose; cytoplasm reticulate. Fig. 216...

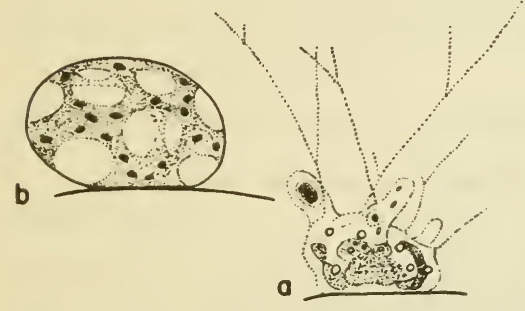

Figure 216

Fig. 216. Perone dimorpha Pascher. $a$, rhizoidal stage; $b$, vegetative cell.

There is a freely moving amoeboid stage and an attached or endophytic encysted stage in the life history of this plant. In the resting stage the cell is to be found in Sphagnum or other moss leaves, with a highly recticulated, faintly pigmented protoplast.

$309 \mathrm{~b}$ Cells shaped otherwise; cytoplasm not highly recticulated nor alveolar. Fig. $217 \ldots \ldots \ldots \ldots \ldots \ldots \ldots \ldots \ldots \ldots$ CHARACIOPSIS

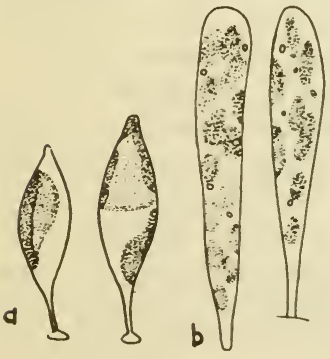

a

Figure 217

Fig. 217. $\alpha$, Characiopsis acuta (Braun) Borzi; b, C. cylindrica (Lambert) Lemm.; c, C. spinifer Printz.

There are several fairly common species of this genus which occur as epiphytes on filamentous algae. They vary in shape and in length of attaching stalk. Unlike the genus Characium (Fig. 87), some species of which are very similar in shape, no starch is formed and the chromatophore is pale green or yellowish-green. The starch-iodide 
test must be used to differentiate the two genera. Characiopsis often shows one to several spherical droplets of oil (?) or other food reserve in the cytoplasm which are not present in Characium.

$310 \alpha$ (307) Cells with a vase-like, pitcher-shaped or globose lorica (envelope) with $a$ neck and a terminal opening. Fig. $218 \ldots \ldots$. . STIPITOCOCCUS

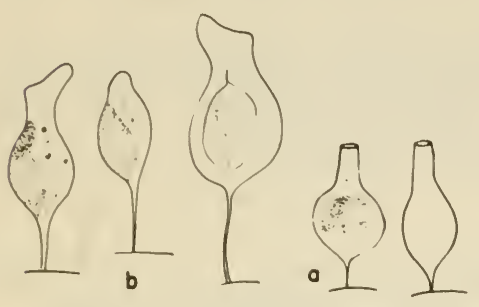

Figure 218

Fig. 218. $a$, Stipitococcus vasiformis Tiffany; b, S. urceolatus West \& West.

There are 3 or 4 species of this genus of rather uncommon occurrence, although in particular habitats the various species are relatively abundant and filamentous algae may be densely overgrown with the epiphytes. S. urceolatus West \& West is perhaps more frequently seen than others and is easily identified because of its distinctive, pitcher-shaped lorica.

$310 \mathrm{~b}$ Cells without a lorica.

31la Cells cylindrical, straight or curved, sometimes with a spine at one or both ends. Fig. 219.............. OPHIOCYTIUM

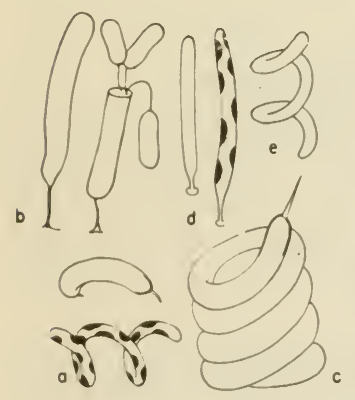

Figure 219

Fig. 219. $a, e$, Ophiocytium parvulum (Perty) Braun; b, O. gracilipes (Braun) Rab.; c, O. cochleare (Eichw.) Braun; d, O. desertum var. minor Presc.

The factors which determine the distribution of this genus are unknown, but there seems to be good evidence that water chemistry determines the presence of these species, of which there are several reported for the United States. Where one species is found, several others also occur as well as many other genera of the Xanthophyceae, a class of the Chrysophyta to which this genus belongs. Species are differentiated by presence or absence of polar spines, and whether freefloating or stalked and epiphytic. They usually occur intermingled with miscellaneous algae from the shallow water of swamps and bogs, occasionally appear in the euplankton of lakes: Most species are solitary but attached forms may be incidentally colonial. 
$311 \mathrm{~b}$ Cells shaped differently.

$312 a$ Cells club-shaped or somewhat pear-shaped; walls in 2 sections, the upper lifting away to permit escape of spores. See Fig. 215. CHLOROTHECIUM

$312 \mathrm{~b}$ Cells spherical, fusiform, or ovoid; wall in 1 piece........313 $313 \alpha$ Stipe slender, thread-like, longer than the cell body. Fig. 220... .PERONIELLA

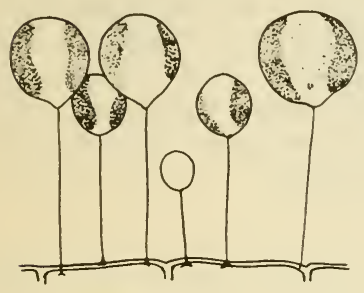

Figure 220

Fig. 220. Peroniella Hyalothecae Gobi.

Species of this genus occur solitarily or in gregarious clusters on other algae, or are attached in the mucilage of colonial forms. The species illustrated seems to occur no other place but on the filamentous desmid, Hyalotheca. Like other members of the Chrysophyta, the chromatophores are not a grassgreen but a pale shade, and there are usually refractive globules of oil or some other kind of food reserve than starch.

$313 b$ Stipe stouter, shorter than the cell body in length (or rarely equalling it). See Fig. $217 \ldots \ldots \ldots \ldots \ldots \ldots \ldots$ CHARACIOPSIS

$314 \alpha(306)$ With 2 flagella of unequal length. Fig. 221. CHLOROCHROMONAS

(OCHROMONAS)

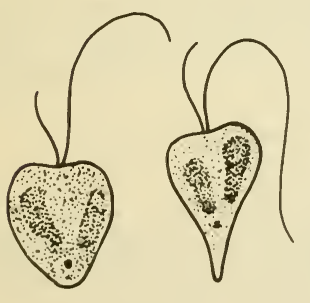

Figure 221

Fig. 221. Chlorochromonas minuta Lewis.

This rare species (probably referrable to Ochromonas) is variable in shape from truncately-oval to pear-shaped. Care must be used in detecting the two flagella of unequal length. Motile, pear-shaped cells in the microscope field, with yellowish chromatophores should be examined for flagella characters. Frequently the cells come to rest and attach themselves to a substrate at the posterior end.

Only one species has been reported in the United States.

$314 \mathrm{~b}$ Without flagella .315

$315 a$ Cell wall smooth

315b Cell wall sculptured or decorated, sometimes spiny

316 a Cells spherical, subglobose, or broadly ovate to subpyriform (pearshaped)

$316 \mathrm{~b}$ Cells rectangular, cylindrical, or crescent-shaped.........320 
317a Cells contained in a gelatinous envelope. Fig. 222.

CHLOROBOTRYS

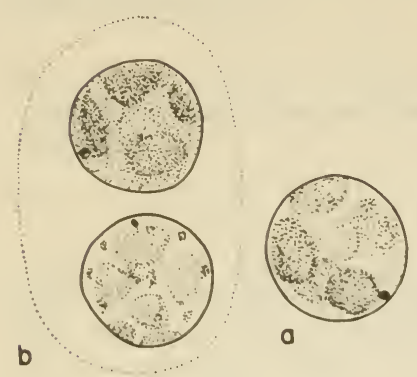

Figure 222

Fig. 222. Chlorobotrys regularis (West) Bohlin. $a$, single cell; $b$, two cells inclosed in common mucilage.

The identifying character of this species is the paired arrangement of the spherical cells inclosed in a mucilaginous sheath. There are several parietal chromatophores and a red spot which is an oil globule. Even though preserved, when some identifying characteristics are lost, the cells retain the dark-colored spot.

$317 \mathrm{~b}$ Cells not inclosed in a gelatinous envelope

318a Cell wall in 2 sections, separating and persisting as membranous sections near the liberated autospores (small replicas of the pqrent cell). Fig. $223 \ldots \ldots \ldots \ldots \ldots \ldots \ldots$. DIACHROS

Fig. 223. Diachros simplex Pascher.

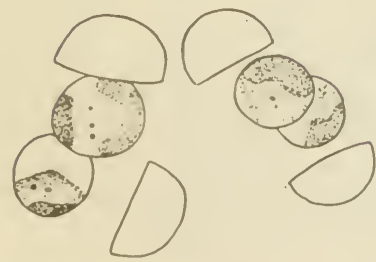

Figure 223

This is the only species reported from the United States. It is somewhat like Schizochlamys (Fig. 48) in the Chlorophyta in that the mother-cell wall fragments are retained after new cells (autospores) are released and these persist as hemispherical, transparent cups near the daughter cells.

318b Cell wall in 1 piece; mother-cell not forming persisting sections but degenerating to liberate spores................... 319 


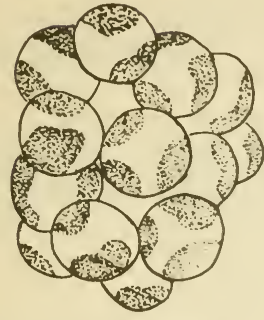

Figure 224

Fig. 224. Botrydiopsis arhiza Borzi.

In the same habitats where Ophiocytium (Fig. 219) occurs one may usually find this species; a solitary, free-floating cell which is either spherical or spheroidal. Small cells, when young, may contain but a single chromatophore, but in age develop many parietal, yellowish-green bodies. Another species, $B$. eriensis Snow, is larger and less commonly seen. Apparently it is a truly planktonic species whereas $B$. arhiza occurs in shallow water (tychoplankton).

319b Cells broadly ovoid or pear-shaped. Fig. 225......LEUVENIA

Fig. 225. Leuvenia natans Gardner. (Redrawn from Smith).

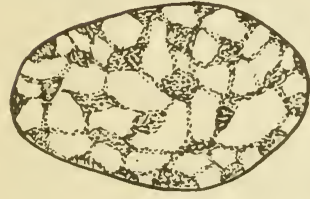

Figure 225

Although essentially unicellular, this species occurs in a dense film at the surface of a quiet pond. Young cells are spherical and have but 1 or 2 chromatophores, whereas older cells become pear-shaped or ovate, and have numerous yellow-green chromatophores. There is but 1 species in the genus and it seems to be rare, having been reported only from California in this country.

320 a (316) Cells rectangular, with a spine at each corner. Fig. 226. PSEUDOTETRAEDRON

Fig. 226. Pseudotetraedron neglectum Pascher.

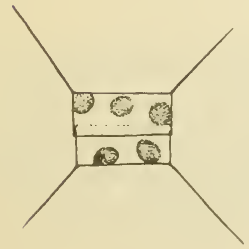

Figure 226

This rectangular cell with a spine at each corner clearly shows the chrysophycean character in its 2-parted wall, the sections overlapping in the midregion of the cell. This can be seen only when the cells are turned on their 'side' of course. In end view the cells are narowly elliptic. There are several yellow-green chromatophores and oil bodies as food reserve. The only species has been reported but rarely from the United States. 
$321 \alpha$ Cells elongate-cylindric, coiled or S-shaped, equally rounded at both poles. See Fig. $219 \ldots \ldots \ldots \ldots \ldots \ldots \ldots$. OPHIOCYTIUM

$321 \mathrm{~b}$ Cells oblong, sides convex, short-cylindric, or fusiform, sometimes not equally rounded at both poles; curved but not coiled, nor twisted .................................... 322

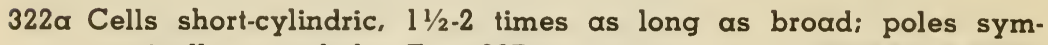
metrically rounded. Fig. $227 \ldots \ldots \ldots \ldots \ldots$..........

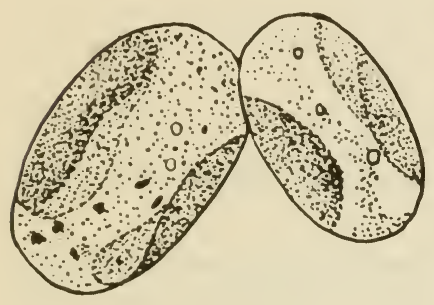

Figure 227

Fig. 227. Monallantus brevicylindrus Pascher.

This is the only species reported from the United States. It occurs in the same habitats with Ophiocytium (Fig. 219) and Bumilleriopsis (Fig. 228).

$322 \mathrm{~b}$ Cells fusiform or cylindric only in part; poles unsymmetrical . . 323

$323 \alpha$ Cells fusiform or sickle-shaped. . . . . . . . . . . . . . . 324

323b Cells irregularly cylindrical; poles unsymmetrical. Fig. 228 BUMILLERIOPSIS

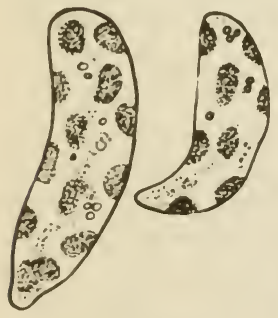

Figure 228
Fig. 228. Bumilleriopsis brevis Pascher.

These cells have yellow-green chromatophores and occur singly or in clusters which are definitely colonial. The irregularly curved cylinders (rarely somewhat fusiform) with the poles of the cells unlike one another in shape, help in identification. 
324a Cells broadly fusiform, abruptly narrowed at the poles. Fig. 229. PLEUROGASTER

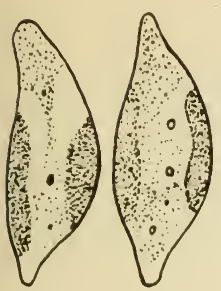

Figure 229

Fig. 229. Pleurogaster lunaris Pascher.

The chief difference between this genus and Bumilleriopsis (Fig. 228) is the definitely fusiform shape, the poles of the cells symmetrical. There are 2 species, differentiated by size and variation in shape, reported from the United States, but like many of the genera of Chrysophyta, they are rare and never occur in pure growths as do so many of the Chlorophyta and $\mathrm{Cy}_{\mathrm{y}}$ anophyta.

324b Cells narrowly fusiform, spindle-shaped or sickle-shaped. Fig. 230

.CHLOROCLOSTER

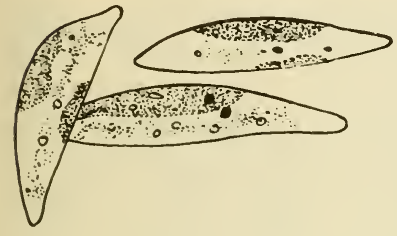

Figure 230

Fig. 230. Chlorocloster pyreniger Pascher.

In this genus the cells are narrowly spindle-shaped and usually are distinctly curved or even sickle-shaped. They are found intermingled sparingly among algal mixtures from shallow water of open bogs, and apparently only where the water is acid. Only 1 species has been reported from the United States.

325a (315) Cells elongate-cylindric, with a spine at one or both poles. 326 $325 \mathrm{~b}$ Cells short-cylindric, spherical or angular............... 327 $326 \alpha$ Cells nearly straight or only slightly bent. Fig. $231 \ldots \ldots \ldots \ldots$
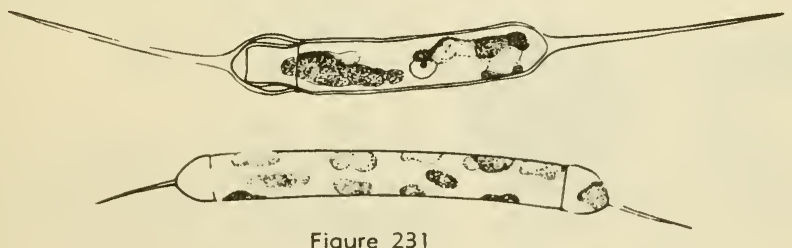

Figure 231

Fig. 231. Centritractus belanophorus Lemm., showing wall in 2 sections.

There are 3 species of the genus reported from the United States, differentiated by size, proportions, and shape of cell. Whereas some are very short, and elliptic when young, others are very long indeed, and straight or slightly curved. It is the straight form that can be used to separate this genus from Ophiocytium (Fig. 219) some species of which it resembles in respect to the overlapping sections of the wall, color of chromatophores, etc. 
326b Cells coiled, S-shaped, or hooked at one end. See Fig. 219

OPHIOCYTIUM

327a (325) Cells spherical

327b Cells some other shape.

.329

328a Cell wall serrate at the margins, the surface of the cell showing broad depressions (sometimes faintly seen). Fig. 232

ARACHNOCHLORIS

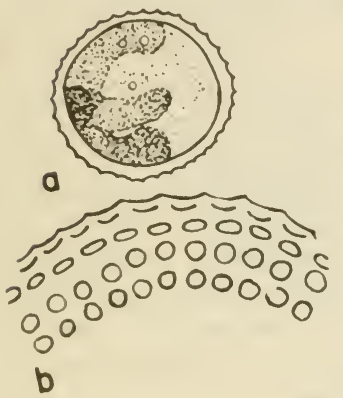

Figure 232

Fig. 232. Arachnochloris minor Pascher. a, cell showing chromatophores; b, sample of wall showing circular, thin areas.

These round cells show the characteristic depressions of the wall at the margin where it appears that the cell is covered with short, sharp spines. These are the tops of ridges formed by slight depressions in the wall that sometimes scarcely can be seen when the cell is viewed in the center. There is but 1 species reported from the United States.

328b Cell wall bearing curved or straight spines. Fig. 233.

MERINGOSPHAERA

Fig. 233. Meringosphaera spinosa Presc.

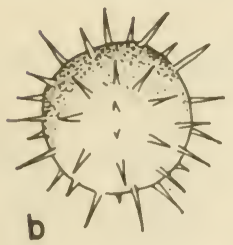

Figure 233

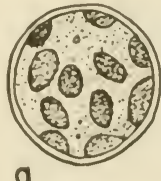

a

a, optical section of cell showing chromatophores; b, exterior of cell showing spines on wall.

In this genus the wall bears long, or short spines or cylindrical, thread-like outgrowths. M. spinosa Presc. questionably has been assigned to this genus from freshwater ponds in this country, although the genus is marine.

$329 a$ (327) Celis broadly fusiform or subtriangular, narrowed abruptly at one or both poles to form spine-like projections. See Fig. 229.

PLEUROGASTER

329b Cells with other shapes. 
$330 a$ Cells oblong to subcylindric; surface of wall with rows of depressions. Fig. $234 \ldots \ldots \ldots \ldots \ldots \ldots \ldots \ldots \ldots \ldots$ CHLORALLANTUS

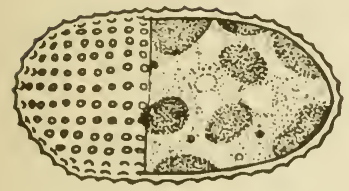

Figure 234

Fig. 234. Chlorallantus oblongus Pascher, represented with portion of wall removed to show chromatophores.

The very regular rows of depressions (forming teeth at the cell margin) help in the identification of this species. The cells are capsule-like in shape and are found scattered about among other algae from open bogs. Only 1 species has been reported from the United States.

330b Cells with other shapes.......................... 331

33la Cells oval or biconvex. Fig. $235 \ldots \ldots \ldots$ TRACHYCHLORON

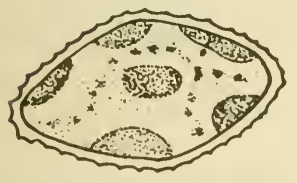

Figure 235

Fig. 235. Trachychloron biconicum Pascher.

Cells of this genus, like Chlorallantus (Fig. 234), have depressions in the wall. They are broadly elliptic or oval or fusiform in shape and contain a gracefully curved chromatophore. But one species has been reported from this country.

$331 \mathrm{~b}$ Cells triangular, pyramidal, or tetragonal................ 332

$332 a$ Cells pyramidal or tetragonal. Fig. $236 \ldots \ldots$ TETRAGONIELLA

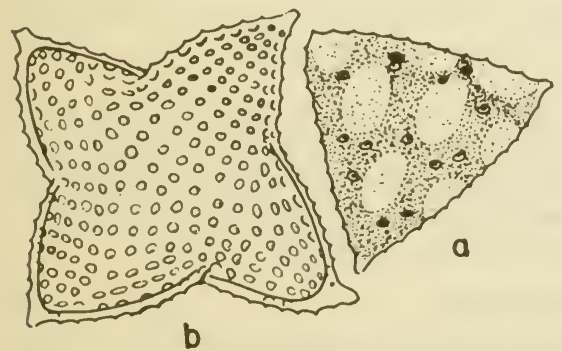

Figure 236

Fig. 236. Tetragoniella gigas Pascher. a, optical section showing chromatophores and reticular nature of the protoplast; $b$, exterior of cell showing scrobiculate wall.

The cells in this genus are beautifully sculptured by regulargly arranged rows of depressions. According to position the cells show different shapes, triangular or tetragonal. One species is reported from mixtures of algae taken from open bogs. 
$332 \mathrm{~b}$ Cells flattened, appearing triangular in face view; fusiform in side view. Fig. $237 \ldots \ldots \ldots \ldots \ldots \ldots \ldots \ldots$. GONIOCHLORIS

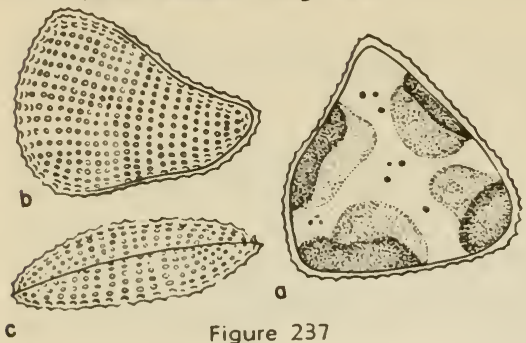

Fig. 237. Goniochloris sculpta Geitler. $a$, optical section showing chromatophores; b, exterior 'front' view, but flattened and narrowly elliptic when seen from the 'side'; $c$, in the lateral view the overlapping of the 2 wall sections sometimes can be detected. There are 4 or 5 curved, plate-like chromatophores. One species only has been reported from the United States.

$333 \alpha(305)$ Cells attached by a stipe...................... 334

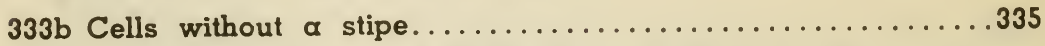

$334 \alpha$ In a globular lorica (envelope) which has an anterior opening. See Fig. $220 \ldots \ldots \ldots \ldots \ldots \ldots \ldots \ldots \ldots \ldots$. . . . . . . . . . . .

334b Not in a lorica. See Fig. $219 \ldots \ldots \ldots \ldots \ldots$ OPHIOCYTIUM

335a (333) With a mucilaginous sheath................... 336

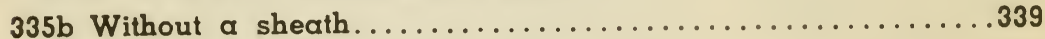

336a Cells numerous, oval, in a globular macroscopic, free-floating colony. Fig. $238 \ldots \ldots \ldots \ldots \ldots \ldots \ldots \ldots \ldots$...............

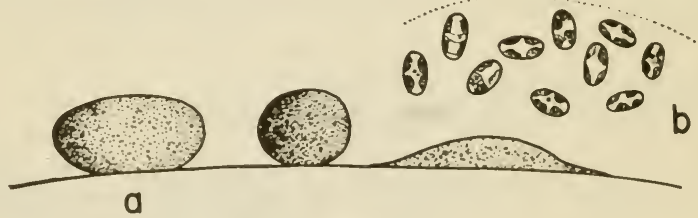

Figure 238

Fig. 238. Chlorosaccus fluidus Luther (Gloeochloris Smithiana Pascher).

$a$, diagram of colony shapes; $b$, cells in mucilage.

This rare species occurs as macroscopic gelatinous balls (up to 20 $\mathrm{mm}$. in diameter) on the stems of submerged plants (including Chara); occasionally may be found free-floating. The colony is composed of irregularly arranged oval cells containing from 2 to 6 parietal chromatophores (yellow-green). There is but one species.

$336 \mathrm{~b}$ Cells shaped or arranged otherwise.................... 337

337a Cells solitary or in pairs at the ends of branched gelatinous tubes.

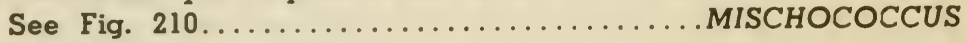

337b Cells arranged otherwise........................ 338 
338a Cells spherical, 2 within $\alpha$ globular envelope. See Fig. 222 .....

338b Cells spherical, many within a gelatinous matrix. Fig. 239...

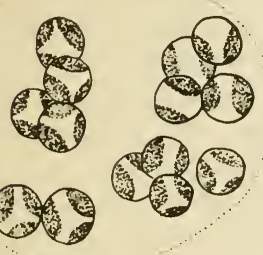

Fig. 239. Gloeobotrys limneticus (G. M. Smith) Pascher.

The chief difference between this genus and Chlorobotrys (Fig. 222) is the presence of a definite mucilaginous sheath about the cells to form colonies. The species illustrated at one time was assigned to Chlorobotrys; described from the open water plankton of lakes.

Figure 239

339a (335) Cells forming loose cushions, in multiples of 2 or 4. Fig. 240. .CHLORELLIDIOPSIS

Fig. 240. Chlorellidiopsis separalibis Pascher.
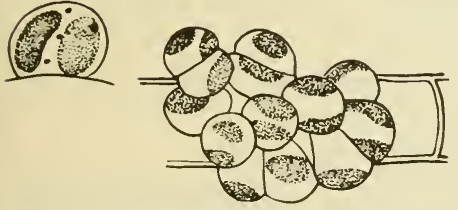

Figure 240

Although cells of this species are sometimes solitary they usually occur in closely grouped clusters on the walls of other algae. There are 2 parietal chromatophores and at least l dark red oil-spot in the mature cells. Only 1 species reported from this country.

$339 \mathrm{~b}$ Cells arranged otherwise

340

$340 a$ Wall in 2 sections which separate to liberate spores (new cells) and which persist nearby: (cells may be incidentally colonial because of gregarious habit). See Fig. $223 \ldots \ldots \ldots \ldots$ DIACHROS

$340 \mathrm{~b}$ Wall in 1 piece, breaking down irregularly to liberate spores: (cells incidentally clustered to form colonies). See Fig. 224.... 
34 la (290) Plant a branched, feathery, gelatinous thallus, the protoplasts crowded in linear series with tough, tublular onvelopes. Fig. $241 \ldots \ldots \ldots \ldots \ldots \ldots \ldots \ldots \ldots \ldots \ldots \ldots \ldots \ldots \ldots \ldots \ldots \ldots$ HYDRUS

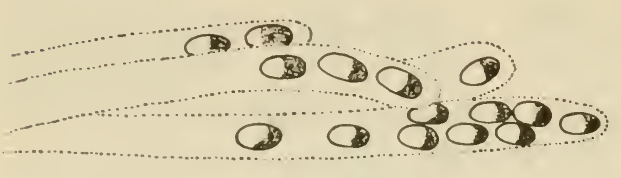

Figure 241

Fig. 241. Hydrurus foetidus (Vill.) Trev. Cells in mucilaginous tubes.

Usually in high mountain streams, this organism forms stringy, brown, gelatinous masses attached to stones. The

bushy, yellow-green or brown tufts contain oval cells arranged in linear series within gelatinous tube-like strands. Sometimes a small stream will be actually choked with the dense growths. The disagreeable odor these plants have is responsible for the specific name. The cells may change into rather curiously shaped, pyramidal zoospores that have but one flagellum.

34lb Plant not a feathery, gelatinous thallus.

342a Sparsely branched, sedentary filaments. Fig. 242. .....................................

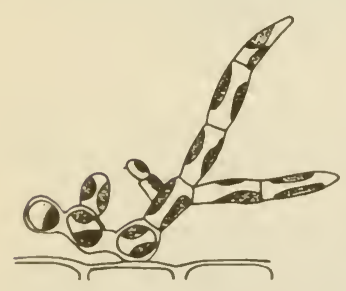

Figure 242

Fig. 242. Phaeothamnion confervicola Lag.

This member of the Chrysophyceae is the only genus in which there is a branched filament. The branches scarcely taper at the ends. The plants are relatively small and grow on the walls of larger filamentous algae. Each cell has a parietal, ochre-green to brownish chromatophore. 
343a A colony of vase-shaped cones (loricas), 1 or 2 cones arising from within the mouth of another and forming forked series. Fig. 243. DINOBRYON

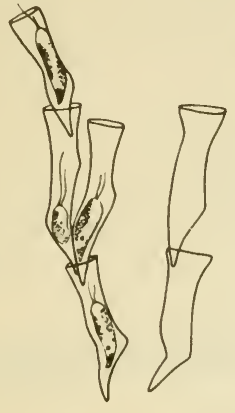

Figure 243

Fig. 243. Dinobryon sertularia Ehr.

There are several species of this genus, all of which are characterized by having the motile protoplasts inclosed within colorless envelopes. The envelopes are usually contained $\mathrm{l}$ or 2 within another so that branching chains are formed. Some species occur as solitary cells, however. The genus is one which inhabits mostly hard water lakes in the euplankton; sometimes are very abundant and produce disagreeable odors and tastes in reservoirs.

343b Cells solitary or arranged otherwise.

344a $\bar{A}$ unicell, consisting of a yellowish protoplast contained in a vaseshaped envelope. See Fig. $243 \ldots \ldots \ldots \ldots \ldots$.........

344b Cells shaped otherwise, solitary or colonial.............345

$345 a$ Cells solitary, colonial or filamentous: wall silicious and etched with grooves or rows of dots which form definite patterns; wall in 2 sections. 1 part forming a lid over a slightly smaller one; oil drops usu-
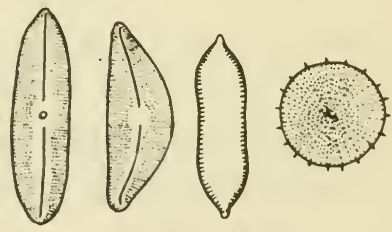

Figure $2431 / 2$ ally conspicuous; solitary cells often showing a gliding or jerky movement. DIATOMS. Fig. $2431 \frac{1}{2} \ldots \ldots \ldots \ldots \ldots \ldots \ldots 450$

345b Cells without silicious walls, so decorated; oil droplets lacking or inconspicuous, not showing gliding movements; if motile, equipped with flagella or moving by pseudopodia (amaeboid fashion)..346

346a Unicelluiar, with flagella but usually not swimming.......347

346b Multicellular or colonial; motile or non-motile...........365 
347a Cell within a variously shaped envelope (lorica), with a flagellum opening.................................. 348

$347 \mathrm{~b}$ Cell without such on envelope........................ 352

348a Envelope cone-shaped, narrowed posteriorly to $\alpha$ blunt or sharp

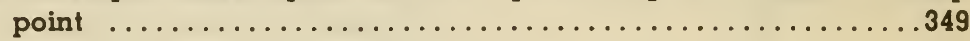

348b Envelope flask-shaped, globose or pyramidal .350

349a Envelope with smooth or slightly wavy margins: without transverse growth rings. See Fig. $243 \ldots \ldots \ldots \ldots \ldots$ DINOBRYON

349b Envelope with marginal, bristle-like projections caused by transverse growth rings. Fig. $244 \ldots \ldots \ldots \ldots \ldots \ldots$. HY ALOBRYON

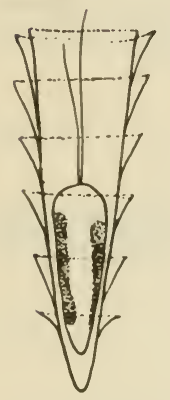

Fig. 244. Hyalobryon mucicola (Lemm.) Pascher.

Figure 244

$350 \propto$ (348) Cells free-swimming; envelope globose, with long spines; flagellum collar narrow. Fig. $245 \ldots \ldots \ldots \ldots$ CHRYSOSTRELLA

Fig. 245. Chrysostrella paradoxa Chod.

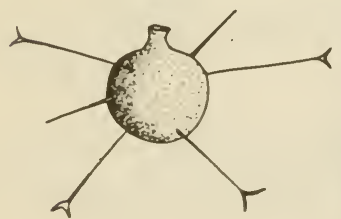

Figure 245

This is the only species reported from this country, occurring either in open water plankton or intermingled among mixtures of algae near shore. The test or envelope bears a few long needle-like setae which are often forked at the tips. The round or oval cells with a short collar around the flagellum aperture make this organism easy of identification.

350b Cells attached, usually not globose; without spines 
35la Envelope vase-shaped; transversely oval or pyramidal with base next to the substrate. Fig. $246 \ldots \ldots \ldots \ldots \ldots \ldots$...........
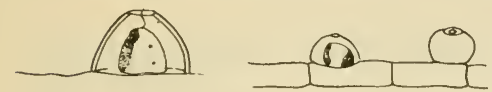

a
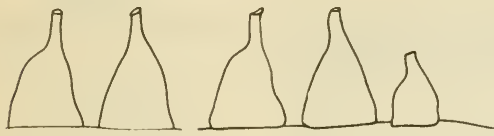

$b$

Figure 246

Fig. 246. $\alpha$, Lagynion reductum Presc.; b, L. triangularis var. pyramidatum Presc.

There are 3 or 4 species of this genus which may be overlooked in algal collections because they are relatively small, often nearly transparent, growing on the walls of filamentous algae. The cells are vase-shaped (triangular in optical section), but this varies somewhat according to species. The protoplast contains a faintly pigmented, yellowish chromatophore.

$35 \mathrm{lb}$ Envelope narrowed in the posterior portion. Fig. 247

DEREPYXIS

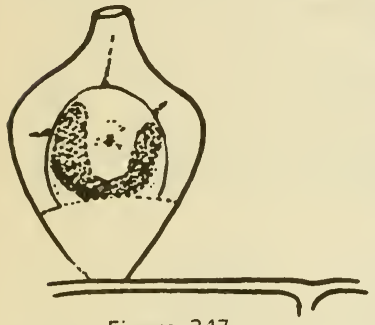

Figure 247

Fig. 247. Derepyxis dispar (Stokes) Senn.

The chief difference between this genus and Lagynion (Fig. 246) is the presence of a supporting membrane through the lorica upon which the protoplast is suspended. This is the only species reported from this country, occurring as a minute epiphyte on filamentous algae.

352a (347) Cells swimming by 1 flagellum; wall impregnated with variously shaped silicious scales (appearing like chain armor) which bear bristles or needles. Fig. $248 \ldots \ldots \ldots \ldots \ldots$ MALLOMONAS

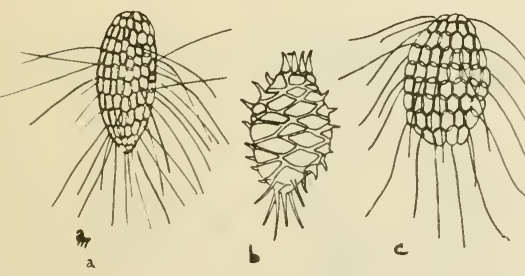

Figure 248

Fig. 248. a, Mallomonas caudata Iwanoff; $b, M$. pseudocoronata Presc.; c, M. acaroides Perty.

These species occur in the open water plankton of mostly hard water lakes, frequently in abundance. They are differentiated one from the oth-

er by the shape and arrangement of the scales in the membrane and in the arrangement of the bristles. They often occur in lakes in which there is a high degree of pollution. Although motile, the single flagellum is hardly distinguishable unless the cells are recently collected and viewed under very favorable optical conditions. 
$352 \mathrm{~b}$ Cells either not motile, or moving by pseudopodia (amoeboid fashion), or by 2 flagella; wall without scales and needles....353

353a Cells amoeboid; protoplast very pale yellow-green or yellowbrown ....................................354

353b Cells swimming by 2 flagella, or sedentary; protoplast deeply pigmented, usually a golden brown or blue.............355

354a Pseudopodia long and needle-like. Fig. 249....RHIZOCHRYSIS

Fig. 249. Rhizochrysis limnetica G. M. Smith. $a$, single cell; $b$,

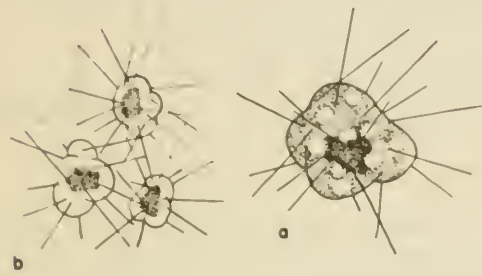

Figure 249 cells in temporary colonial arrangement.

This is the only species of the genus reported in the United States. The amoeboid member of the Chrysophyta has long, slender needle-like pseudopodia. Cells are ordinarily solitary but may occur in loose, temporarily united colonies.

354b Pseudopodia short, tapering from the base to a fine point. Fig. 250 CHRYSAMOEBA

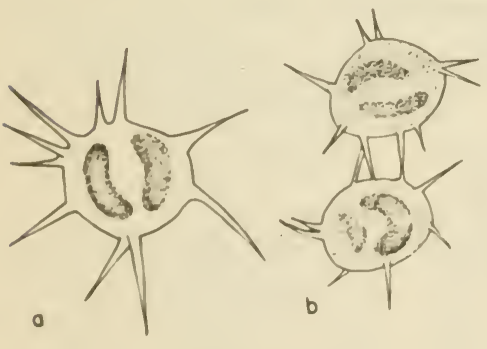

Figure 250

Fig. 250. Chrysamoeba radians Klebs. $a$, single cell; $b$, temporarily adjoined cells.

This species, the only one reported, occurs more commonly than Rhizochrysis (Fig. 249). Usually the cells occur in an amoeboid condition, bearing short, sharply pointed pseudopodia, but may change to a condition in which a single flagellum is present as a locomotory organ.

355a (353) Cells attached 
356a Cells inversely triangular, or tetrahedral in top view, angles tipped with 1 or 2 spines. Fig. $251 \ldots \ldots \ldots \ldots \ldots$.......... TETRADINIUM

Fig. 251. Tetradinium simplex Presc. $\alpha$, side view; b, vertical view.

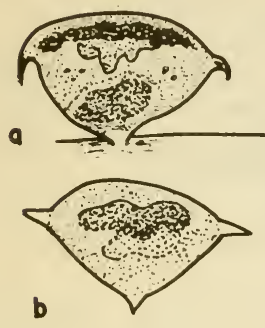

Figure 251

The chromatophores of this sessile member of the dinoflagellates are typically brown. The four corners of the cell are tipped with 2 short spines. This and 1 other species, T. javanicum Klebs, have been reported as epiphytes on filamentous algae. It should be compared with Raciborskia (Fig. 252) in making determinations.

$356 \mathrm{~b}$ Cells inversely triangular, elliptic in top view, the outer free angles tipped with 1 stout spine. Fig. $252 \ldots \ldots \ldots \ldots \ldots$. RACIBORSKIA

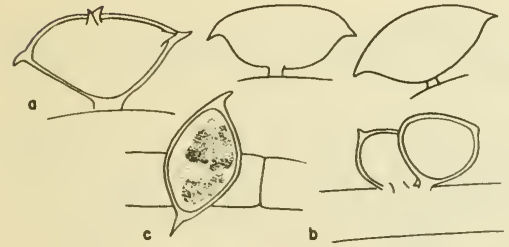

Figure 252

Fig. 252. Raciborskia bicornis Wolosz. $a$, side view, showing stipe; $b$, top and lateral view.

These are elliptical cells, sessile on a short stalk and attached to filamentous algae or aquatic mosses. There is a single spine at each pole of the cell. One species only has been reported from the United States. Compare with Tetradinium (Fig. 252) in making determinations.

$357 \alpha$ (355) Cells crescent-shaped, the horns extended to form a spinelike tip which is recurved in most species. Fig. $253 \ldots \ldots \ldots \ldots$.

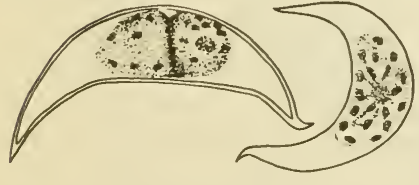

Figure 253

Fig. 253. Cystodinium cornifax (Schiller) Klebs.

This and 2 or 3 other species occur as free-floating members of the encysted type of dinoflagellates. They are differentiated on the basis of variations of the crescent-shaped cells, with the horns twisted at various angles. Several species of Tetraedron (Fig. 131) have been incorrectly described from members of this genus. 
357b Cells not crescent-shaped

$358 \alpha$ Cells broadly oval, ovate, or obovate, with $\alpha$ truncate or bilobed anterior end; flagella 2, attached at the anterior end; chromatophores 2, lateral elongate plates.....................359

358b Cells shaped otherwise; flagella not anterior

.360

359 a Cells without a gullet in the anterior end, but with $\alpha$ slight apical depression. Fig. 254................... CHROOMONAS

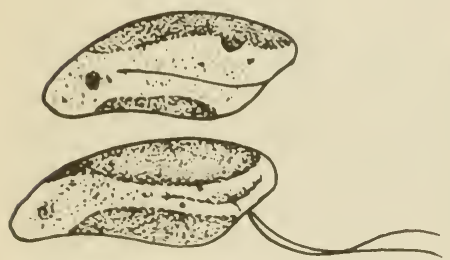

Figure 254

Fig. 254. Chroomonas Nordstedtii Hansg.

These minute, slipper-shaped organisms have 2 parietal, blue chromatophores, and 2 flagella that are attached just below the apex of the cell. They move rapidly and determinations cannot be made unless some medium is introduced to the mount to slow down their action. Use 5\% glycerin.

359b Cells with a gullet. Fig. 255.............. CRYPTOMONAS

Fig. 255. Cryptomonas erosa Ehr.

There are probably several species of

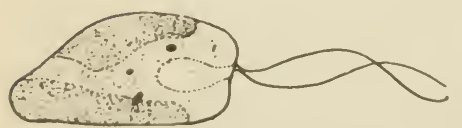

Figure 255 this genus, but few are reported probably because they are easily overlooked among dense mixtures of algae where they mostly occur. The cells are relatively larger than Chroomonas (Fig. 254) and have a gullet at the anterior end which can be seen as the cells rotate on their axis. 
$360 \alpha$ (358) Cells with a long anterior horn and 2 or 3 posterior horns.

Fig. $256 \ldots \ldots \ldots \ldots \ldots \ldots \ldots \ldots \ldots \ldots \ldots \ldots \ldots \ldots \ldots \ldots \ldots \ldots$ CERATIUM

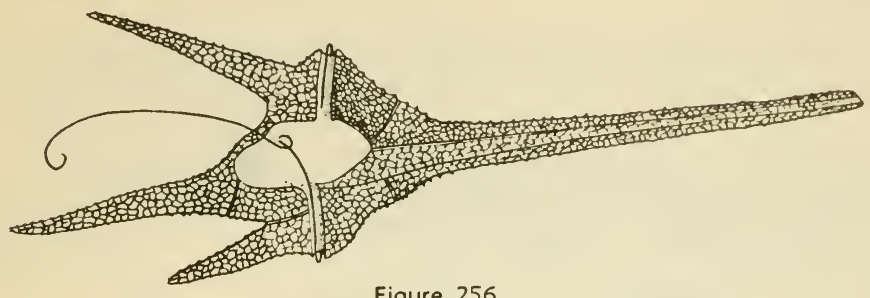

Figure 256

Fig. 256. Ceratium hirundinella (O. F. M.) Duj.

This distinctive organism is unmistakably identified. It occurs either intermingled with other algae or in the open water of lakes where, under favorable conditions, it may produce a veritable bloom and may cause the water to be a gray-brown or coffee color. When recently collected, favorable optical conditions will show the trailing flagellum and the one that encircles the cell in the transverse groove. Most species of this genus occur in the sea.

$360 \mathrm{~b}$ Cells without prominent horns as above................ 361

361 a Cells without a true wall; membrane delicate, not showing a pattern of plates; with a transverse groove which completely encircles the cell. Fig. $257 \ldots \ldots \ldots \ldots \ldots \ldots \ldots$. GYMNODINIUM
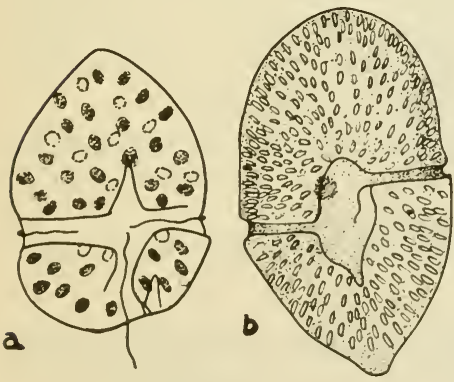

Figure 257

Fig. 257. a, Gymnodinium palustre Schilling; b, G. fuscum (Ehr.) Stein.

Species of this genus are of wide occurrence but seldom occur in large numbers. They are intermingled among other algae and are usually found very actively swimming in microscope mounts. The thin cell membrane (without a cell wall) that characterizes most fresh-water species helps in identification. The transverse furrow extends around the cell in a downward spiral fashion.

$361 \mathrm{~b}$ Cells with a definite wall; a pattern of definitely arranged plates usually evident; $\alpha$ transverse groove encircling the cell, completely or incompletely.............................. 362 
$362 \alpha$ Wall thick; plates easily seen, with $\alpha$ suture between the plates usually evident; transverse furrow completely encircling the cell.

$362 \mathrm{~b}$ Wall thin; plates seen with difficulty (especially in filled and living cells); transverse furrow completely encircling the cell or not. .364

$363 \alpha$ Wall with 2 antapical plates (plates at the posterior pole, to be seen in end view of the cell); cell slightly flattened dorsiventrally in most species. Fig. $258 \ldots \ldots \ldots \ldots \ldots \ldots \ldots$. PERIDINIUM

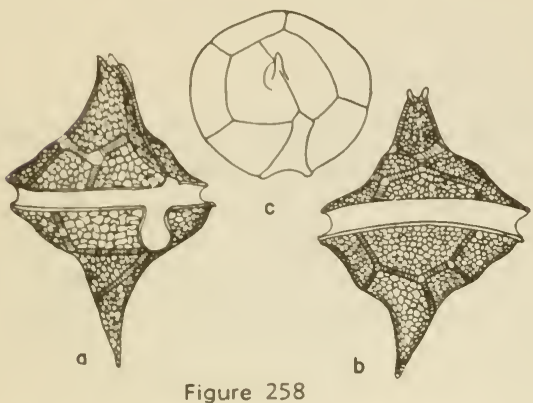

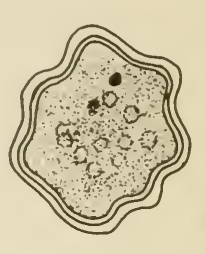

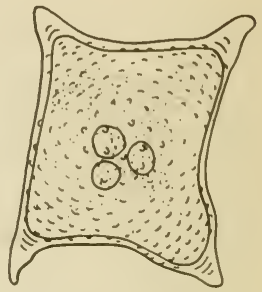

Figure $2581 / 2$

Fig. 258. Peridinium wisconsinense Eddy. $a$, ventral view showing longitudinal sulcus; $b$, dorsal view; $c$, posterior polar view showing

2 antapical plates.

Fig. 2581/2. Encysted Dinoflagellates.

This genus is represented by more species in fresh water than any of the other dinoflagellates. They are differentiated by shape, size and details of plate number and arrangement. The 2 posterior or antapical plates can be determined by patiently rolling the cell so that it can be seen from the bottom. Although very common, these species do not form blooms nor pure growths as does Ceratium (Fig. 256).

$363 \mathrm{~b}$ Wall with 1 antapical plate; cell not flattened dorsiventrally (round in cross section). Fig. 259..................WY AULAX

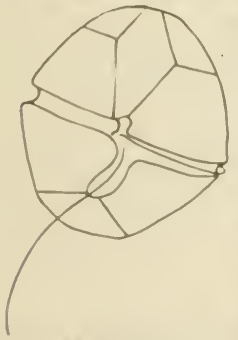

Figure 259

Fig. 259. Gonyaulax palustre Lemm.

These almost spherical cells are differentiated from Peridinium (Fig. 258) by the presence of but a single antapical plate and the slightly spiralled transverse furrow. Some authorities regard this particular species of the genus as belonging to Peridinium. 
364a (362) Cells strongly flattened dorsiventrally; plates not evident; transverse furrow not completely encircling the cell. Fig. $260 \ldots$

.HEMIDINIUM

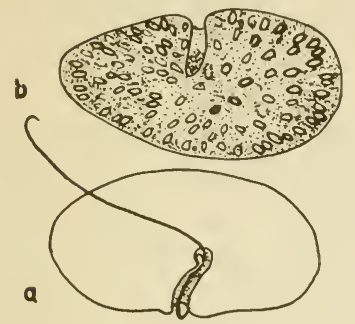

Figure 260

Fig. 260. Hemidinium nasutum Stein. a, ventral view; b, dorsal view.

There are several species of this genus reported from the United States. They are differentiated by shape and size of cell and by the pattern of the plates which are usually very delicate and difficult of determination. The cells are very much flattened when seen from the side.

364b Cells not at all or but very little flattened dorsiventrally (nearly round in cross section); plates evident (especially in empty cells); transverse furrow completely encircling the cell. Fig. $261 \ldots \ldots \ldots$

GLENODINIUM

Fig. 261. Glenodinium Kulczynski (Wolos.) Schiller. $a$, ventral view showing longitudi-

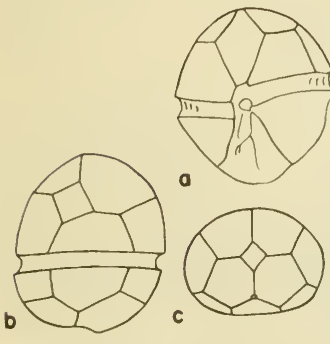

Figure 261 nal furrow; b, dorsal view; $c$, apical view.

The several species of this genus reported from the United States are differentiated by cell size and shape. The plate pattern is much more easily discerned than in Hemidinium (Fig. 260) but patience is required in rotating the cell in order to determine this pattern. As in other genera, especially Peridinium (Fig. 258 ) it is desirable to examine empty cells in order to see the wall characters plainly. Most species are globular or if flattened, not so much as in Hemidinium.

365a (346) Colony motile by flagella..................... 366

365b Colony non-motile, or if moving, by rhizopodial processes (pseudo-

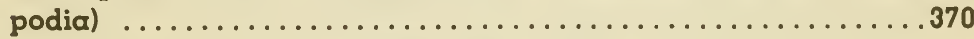

366a Colony globose or subglobose (oval); cells ovoid or pear-shaped, compactly arranged or forming a hollow sphere............367

366b Colony not globular; cells shaped otherwise...............369 
367 a Cells bearing 2 long, rigid, rod-like processes at the anterior end.

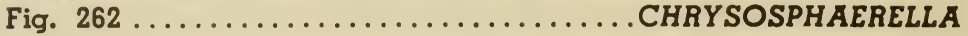

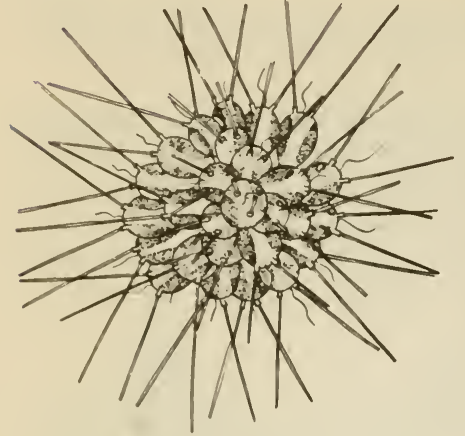

Fig. 262. Chrysosphaerella longispina Lauterb.

This distinctive organism is easily identified by the curious long rods, borne in pairs on each cell. The chromatophores are brownish-yellow. Although widely distributed the species (only 1 reported) seems to be rather rare in occurrence.

367b Cells without such rods.

368a Cells elongate-ellipsoid or elongate pear-shaped, rather compactly arranged in the colony; cell wall with minute silicious scales in the anterior end; flagella 2, of equal length. Fig. 263....SYNURA

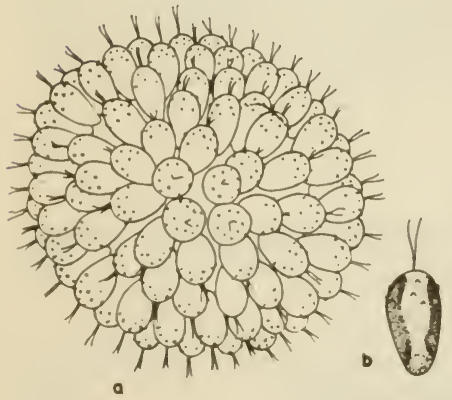

Figure 263
Fig. 263. Synura uvella Ehr. a, colony; b, single cell showing silicious spicules in membrane.

This species is very common in hard water lakes and may be so abundant as to produce disagreeable odors and tastes in water supply reservoirs. The chromatophores are golden brown and mask the small spicules in the walls at the anterior end of the cell. These can be determined by proper focusing on colonies that are quiescent. There is another species with longer and narrower cells, S. Adamsii G. M. Smith, that is of more rare occurrence. 
368b Cells ovoid or pear-shaped, separated and evenly spaced within the colonial envelope; without scales in the wall; flagella 2 , of unequal length. Fig. $264 \ldots \ldots \ldots \ldots \ldots \ldots$ UROGLENOPSIS

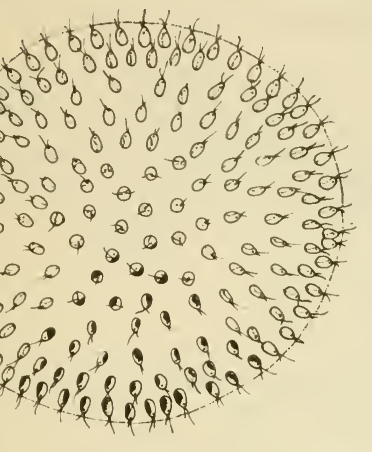

Fig. 264. Uroglenopsis americana (Calkins) Lemm.

This species frequents bodies of water that are contaminated with sewage and organic wastes. The colonies are large and contain several hundreds of cells, are sometimes mistaken for Volvox (Fig. 15) but is quickly differentiated by the yellow-brown color of the plate-like (not cup-shaped) chromatophores.

Figure 264

369a (366) Cells elongate-ovoid or pear-shaped, compactly arranged side by side in radiate fashion in 1 plane to form $\alpha$ plate with $\alpha$ small opening in the center of the colony; motile by 2 flagella.

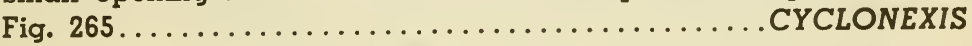

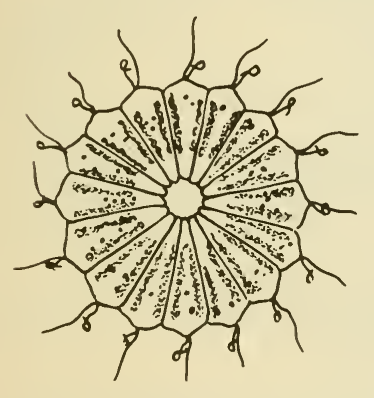

Fig. 265. Cyclonexis annularis Stokes. (Redrawn from Stokes).

The flat, disc-like colony of compactly arranged, pear-shaped cells is very distinctive. The flagella are relatively coarse and can be seen easily when the colony is quiescent. There are 2 elongate, lightly pigmented chromatophores.

Figure 265

$369 \mathrm{~b}$ Cells not as above; contained in a vase-shaped envelope, 1 or 2 such envelopes arising from the mouth of the one below to form a branched series. See Fig. 243............. DINOBRYON

$370 \alpha$ (365) Individuals furnished with pseudopodia (colony sometimes loosely formed and only temporary).................. 371

$370 \mathrm{~b}$ Individuals not furnished with organs of locomotion; colonies non-motile 
$371 \alpha$ Cells joined together by long, narrow protoplasmic extensions, arranged in a linear series. Fig. 266....... CHRYSIDIASTRUM

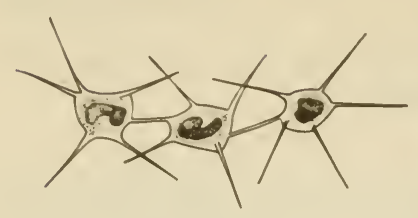

Figure 266

Fig. 266. Chrysidiastrum catenatum Lauter. (Redrawn from Smith).

Although this organism may occur singly it is-frequently seen adjoined in loose colonies by the interconnecting pseudopodia. There is 1 , plate-like or disc-shaped chromatophore.

$371 \mathrm{~b}$ Cells not joined as above.

$372 \alpha$ Pseudopodia numerous, radiating needles; colony formation mostly temporary and incidental. See Fig. 249.....RHIZOCHRYSIS

372b Pseudopodia short protoplasmic extensions which join individuals to form temporary colonies. See Fig. 250..... CHRYSAMOEBA

$373 a$ (370) Colony consisting of vase-shaped envelopes, 1 or 2 such envelopes arising from the mouth of one below to form forked series (organisms actually motile by flagella, but often appearing quiescent with flagella completely invisible in microscope mounts). See Fig. $243 \ldots \ldots \ldots \ldots \ldots \ldots \ldots \ldots$. . . . .

373b Individuals not cone-shaped; colony formed otherwise.......374

$374 a$ Thallus a sparsely branched gelatinous cylinder or a mucilaginous network, with cells arranged in 1 to several irregular linear series. Fig. 267 . . PHAEOSPHAERA

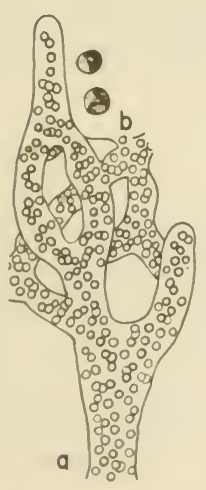

Figure 267
Fig. 267. Phaeosphaera perforata Whitford. $a$, small portion of perforate colony; $b$, cells showing chromatophores.

The golden brown cells of this species occur in gelatinous masses of irregular shape and of macroscopic size. The thallus may be a stringy mass of mucilage occurring in skeins or meshworks. Unlike Tetraspora (Fig. 35) with which it might be mistaken, the cells are not arranged in groups of 4 but occur in irregular series throughout the gelatinous strands.

$374 \mathrm{~b}$ Thallus not a branched gelatinous strand or network 375 
375a Cells in clusters of 2-4-8-16 within an irregularly globose colonial investment. Fig. 268................. CHRYSOCAPSA

Fig. 268. Chrysocapsa planctonica (West

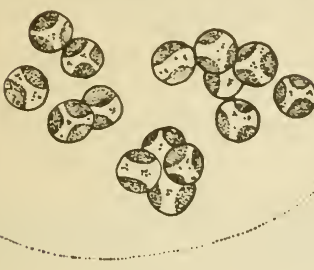

Figure 268

\& West) Pascher. (Redrawn from Smith).

The colonies of this species are globular, or nearly so, the mucilage clear and transparent, the cells with brownish chromatophores. This is the only species reported which is common, but another one, C. paludosa (West \& West) Pascher, with oval cells has been recorded.

375b Cells 16-32-64 within a wide, flat colonial mucilage, the cells radially arranged in 1 plane; colonial mucilage impregnated with granular substance. Fig. 269..... CHRYSOSTEPHANOSPHAERA

Fig. 269. Chrysostephanosphaera globulifera Scherff.

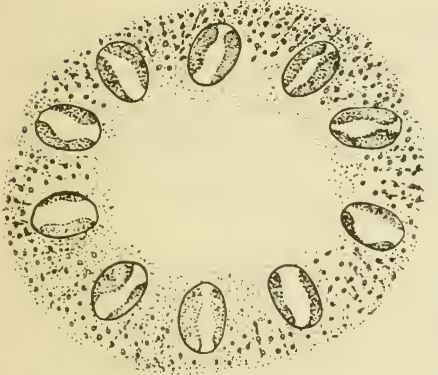

Figure 259
This colony of brown cells is disclike and is enclosed by a wide gelatinous matrix which invariably contains dark granules of what is regarded as metabolic waste products. Only 1 species is known from this country.

376a (4) Plants filamentous, thread-like (the thread of cells called a trichome; trichome and sheath, if present, called a filament)...377

376b Plants not definitely filamentous; cells globular, rod-shaped, or angular from mutual compression; solitary, in floating colonies, or forming cushion-like masses in which a suggestion of filamentous arrangement may be apparent...................421

377a Trichome coiled or spiralled in a regular fashion...........378

377b Trichomes otherwise, straight or irregularly twisted (occasionally, however, Oscillatoria (Fig. 277) may become twisted about itself to form a regular spiral) .381 
$378 \alpha$ Trichome unicellular. Fig. $270 \ldots \ldots \ldots \ldots \ldots \ldots$ SPIRULINA

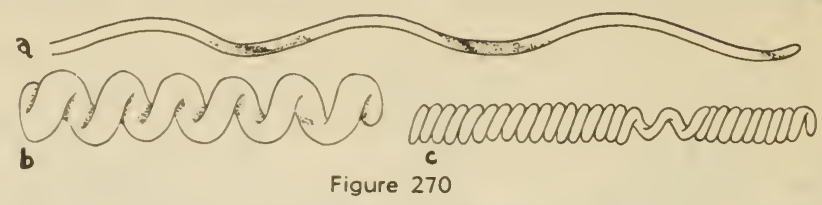

Fig. 270. a, Spirulina laxissima G. S. West; b, S. princeps (West \& West) G. S. West; c, S. subsalsa Oersted.

Although essentially unicellular, this genus is thread-like and is included with the Oscillatoriaceae (a filamentous family of the Cyanophyta). Although some species are solitary they are often found in masses either by themselves or intermingled with Oscillatoria (Fig. 277). Species are differentiated by size and by type of coiling of the cell. They are usually actively in motion when viewed microscopically. Movement in this and other blue-green genera is accomplished by the extrusion of mucilage.

$378 \mathrm{~b}$ Trichomes multicellular, i.e., with cross walls.............379

379a Trichomes composed of bead-like or barrel-shaped cells, with heterocysts present (cells located here and there in the trichome which are larger and sometimes different in shape from the vegetative

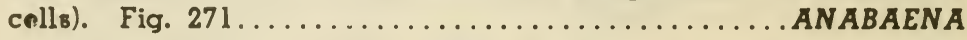

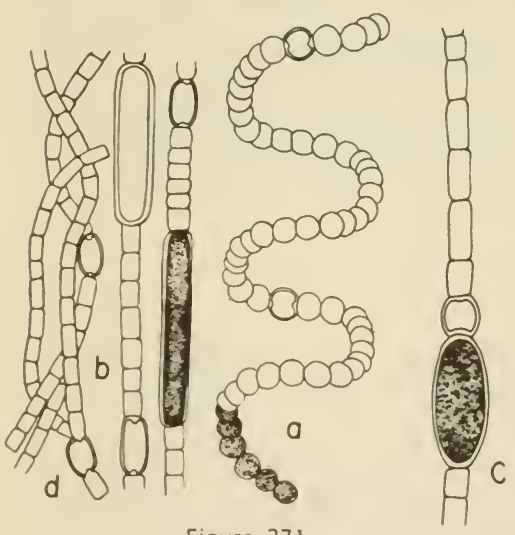

Figure 271

Fig. 271. $\alpha$, Anabaena spiroides var. crassa Lemm.; b, $A$. subcylindrica Borge, showing spores; c, $A$. sp., showing oval akinete; $d, A$. subcylindrica Borge, showing heterocysts.

There are many species of this genus, some solitary and some forming colonial masses of indefinite shape. When colonial they are surrounded by a conspicuous mucilage and sometimes are mis. taken for Nostoc (Fig. 300). The colonial mass is indefinite in shape and the mucilage soft, however. Whereas some forms are truly planktonic species, others occur intermingled with algae in shallow water or on moist soil. The planktonic species may form a bloom in lakes of northern latitudes during summer months, but seldom cause disagreeable conditions in lakes or reservoirs because the plants remain suspended throughout the water and do not form surface scums. Anabaena spp. are responsible for the death of cattle and other animals drinking from infested water. 
379b Cells not bead-like; heterocysts absent................. 380

$380 \alpha$ Trichomes with a sheath. Fig. $272 \ldots \ldots \ldots \ldots \ldots L$. . . .

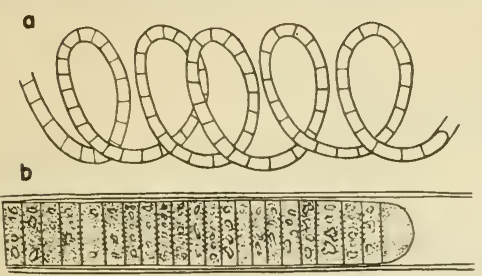

Figure 272

Fig. 272. a, Lyngbya contorta Lemm; b, L. Birgei G. M. Smith.

Most species are straight and rigid, but a few are coiled; some are planktonic. The definite, rather firm sheath exending beyond the end of the trichome (the row of cells) is characteristic and helps to separate this genus from Oscillatoria (Fig. 277). One species, L. Birgei, is so characteristically a planktonic species in hard water that it can be used as an index organism.

$380 \mathrm{~b}$ Trichomes without $\alpha$ sheath. Fig. $273 \ldots \ldots \ldots$ ARTHROSPIRA

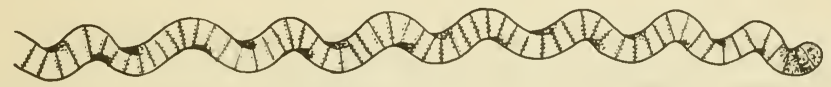

Figure 273

Fig. 273. Arthrospira Jenneri (Kuetz.) Stiz.

The plants in this genus are multicellular but at times the cross partitions are difficult to discern and short sections may be mistaken for Spirulina (Fig. 270). Species are differentiated mostly by size and form of coiling of the filaments; occur on damp soil of beaches, or in the tychoplankton.

$381 \alpha$ (377) Trichomes with cells all alike in shape and size (except trichome) may be tapered, or the apical cell capitate (swollen).382

381b Trichomes with certain cells enlarged and appearing empty or with homogeneous contents (heterocysts); in some, certain cells become enlarged and develop thick walls, forming spores (akinetes) ..................................... 397

$382 a$ Trichomes tapering from base to apex................. 383

382b Trichomes not tapering from base to apex, the same diameter throughout, or tapered only in the extreme apical region.....385 
383a Trichomes aggregated, tapering from a base which is incorporated in a prostrate cushion of cells. Fig. 274........ AMPHITHRIX

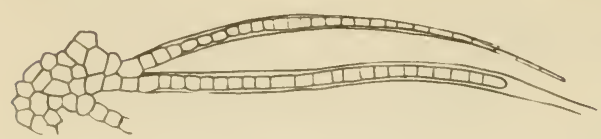

Figure 274

Fig. 274. Amphithrix janthind (Mont.) Bor. \& Flah. (Redrawn from Bornet \& Flahault).

These tapering filaments are arranged in somewhat parallel fashion to form clusters (but without conspicuous mucilage) attached to substrates. There is a weakly developed, prostrate expansion of the thallus from which the filaments arise. The lack of heterocysts (see Anabaena, Fig. 271) makes this a somewhat anomalous member of the Rivulariaceae which characteristically has this type of cell at the base of the filament.

$383 \mathrm{~b}$ Without a prostrate cushion of cells at the base of the trichome. .384

384a Trichomes gregarious, parallel in a colonial mass. See Fig. 274. AMPHITHRIX

384b Trichomes solitary or loosely clustered, not parallel. Fig. 275 ... CALOTHRIX

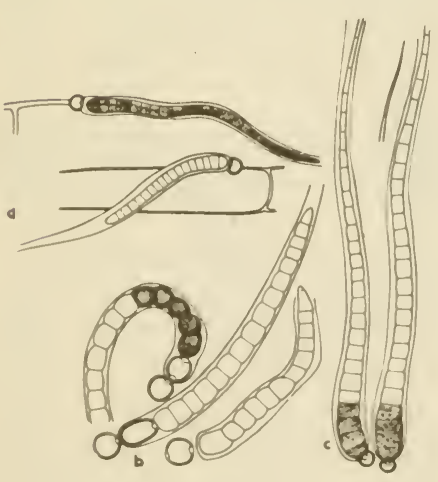

Figure 275
Fig. 275. a, Calothrix epiphytica West \& West; b, C. atricha Fremy; c, C. Braunii Bor. \& Flah.

These tapering filaments are solitary or loosely clustered, although sometimes gregarious, forming extensive masses. There is a basal heterocyst and in some species, akinetes. Species are differentiated on the basis of size, presence or absence of akinetes, and by the degree of tapering of the trichome, some being very abrupt. 
$385 a$ (382) Filaments bearing false branches ( $\alpha$ branch formed by proliferation of $a$ broken trichome which pushes off to one side of the main axis; not branching by lateral division of a cell in the main axis); branching often sparse. Fig. 276.........PLECTONEMA

Fig. 276. Plectonema Wollei

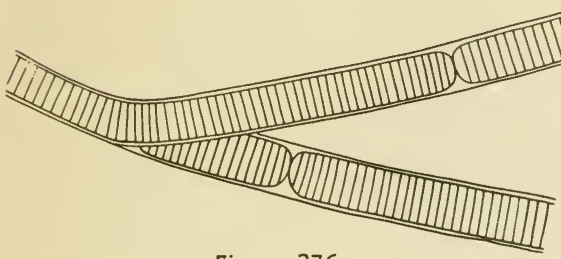

Figure 276

The false habit of branching places this genus in the Scytonemataceae, but unlike other members of the family there are no heterocysts. The species illustrated is a common one, occurring in brownish green or black, cottony masses at or near the surface of the water; is a relatively large species being up to $50 \mu$ in diameter.

$385 \mathrm{~b}$ Filaments not branched...............................

$386 \alpha$ Trichomes without $\alpha$ sheath............................

$386 \mathrm{~b}$ Trichomes with $a$ sheath.............................

$387 \alpha$ Trichomes solitary or intermingled, not lying in parallel bundles, sometimes tapered slightly at the anterior end, or with the apical cell swollen (capitate). Fig. $277 \ldots \ldots \ldots \ldots \ldots$ OSCILLATORIA

a

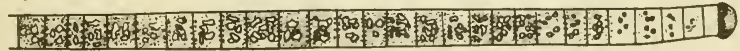

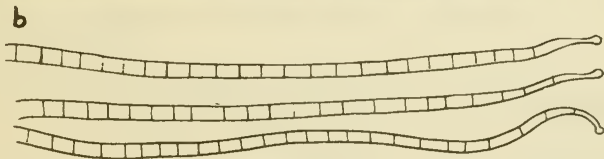

Figure 277

Fig. 277. a, Oscillatoria rubescens DeCand.; b, O. splendida Grev.

The chief characteristic of species in this genus is their lack of a sheath and another one is their active, oscillating movement. $\bar{A}$ mass of the plants left in a laboratory dish will creep up the sides of the container. There are numerous species, differentiated on the basis of size and cell proportions and also upon the morphology of the apex of the trichome, sometimes being straight and not tapering, sometimes tapering and possessing a swollen apical cell. 
387b Trichomes lying in parallel bundles, not tapered at the anterior end; apical cell never capitate. Fig. 278......TRICHODESMIUM

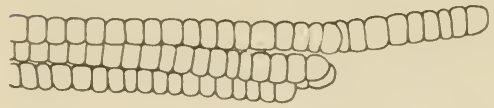

Figure 278

Fig. 278. Trichodesmium lacustre Kleb.

This is a species of uncertain position because it has an Anabaena-like filament, but without heterocysts. The filaments are arranged in parallel bundles which form free-floating, dark-green flakes. The cells contain numerous pseudovacuoles (gas pockets). T. erythraceum Ehr. is a marine species which, because of light refraction from pseudovacuoles, produces a color that gives the Red Sea its name.

$388 \alpha(386)$ Sheath containing one trichome..................... 389

388b Sheath containing more than one trichome.............394

$389 \alpha$ Sheath firm and definite, not adhering to sheaths of adjacent fila-

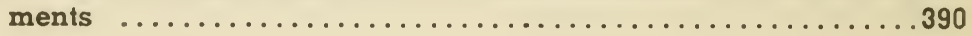

$389 \mathrm{~b}$ Sheath soft and sticky, often adhering to sheaths of adjacent plants and intermingling (confluent) with them...........391

390a Sheaths purple or reddish, conspicuously stratified. Fig. 279... PORPHYROSIPHON

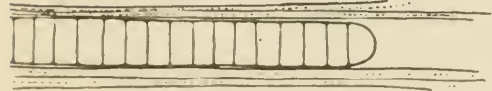

Figure 279

Fig. 279. Porphyrosiphon Notarisii (Menegh.) Kuetz.

The purple color of the lamellated sheath of this species accounts for the brightly colored patches on damp soil in subtropical sections of the country. There is but 1 species recorded for the United States.

$390 \mathrm{~b}$ Sheaths colorless or yellowish, not stratified, or indistinctly so.

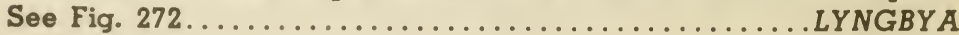


391a (389) Filaments forming an expanded plant mass with or without erect tufts .................................. 392

$391 \mathrm{~b}$ Filaments not forming an expanded mass or stratum........393

$392 \alpha$ Plant mass having erect tufts. Fig. $280 \ldots \ldots \ldots \ldots$ SYMPLOCA

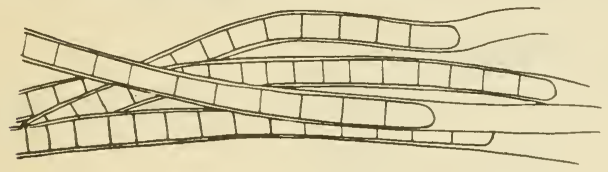

Figure 280

Fig. 280. Symploco muscorum (Ag.) Gom.

Filaments of this species occur in erect tufts in mo is t aerial situations. Species which have thin, sticky sheaths should be compared with Phormidium (Fig. 281) with which they may be confused if seen individually and not in colonial mass.

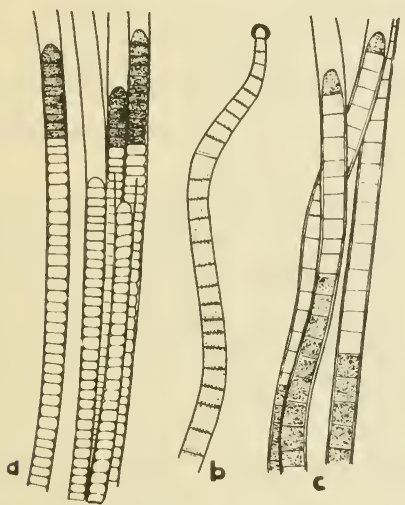

$392 b$ Plant mass without erect tufts. Fig. $281 \ldots \ldots \ldots$. PHORMIDIUM

Figure 281

Fig. 281. a, Phormidium ambiguum Gom.; b, P. favosum (Bory) Gom.; $c, P$. inundatum Kuetz.

There are numerous species of this genus, differentiated by size and by characteristics of the apical cell of the trichome. The sheaths are thin and sticky, hence the plants form rather closely compacted mats that coat over submerged surfaces. Such a mat when handled does not break apart easily (as somewhat similar-appearing growths of Oscillatoria, Fig. 277, might do). The plant masses are blue- or black-green in color and feel slimy or slippery to the touch.

393a (391) Filaments lying parallel in free-floating bundles. See Fig. 
$393 \mathrm{~b}$ Filaments irregularly intermingled, not arranged in free-floating bundles. Fig. $281 \frac{1}{2} \ldots \ldots \ldots \ldots \ldots \ldots \ldots \ldots$. . . . . . . . . .

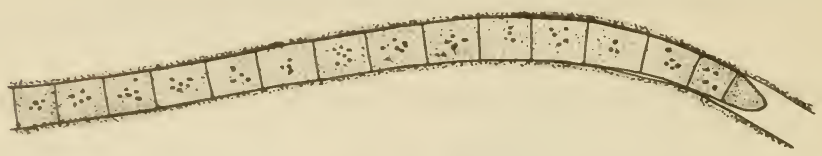

Figure $281 \frac{1}{2}$

Fig. $281 \frac{1}{2}$. Phormidium sp. Isolated filament.

$394 \alpha$ (388) Sheaths soft and sticky, without an even, definite outer boun-

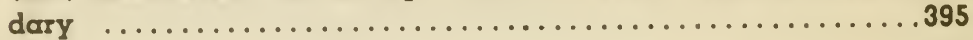

394b Sheaths firm and definite, not mucilaginous.............. 396

395 $\alpha$ Sheaths containing 2 or 3 trichomes. Fig. 282...HYDROCOLEUM

Fig. 282. Hydrocoleum oligotrichum A. Braun.

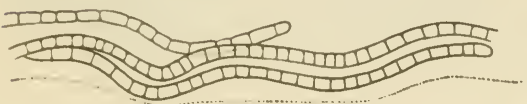

Figure 282

In this genus there are only 3 (sometimes 4) trichomes within a wide, lamellate, gelatinous sheath. The filaments may be solitary or spread in a thin layer on damp soil. $H$. oligotrichum usually is limeencrusted, whereas $H$. homeotrichum Kuetz. is not.

395b Sheaths containing many trichomes. Fig. 283....MICROCOLEUS

Fig. 283. $a$, Microcoleus vaginatus (Vauch.) Gom.; b, $M$. lacustris (Rab.) Farlow.

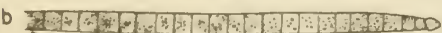

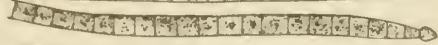

a

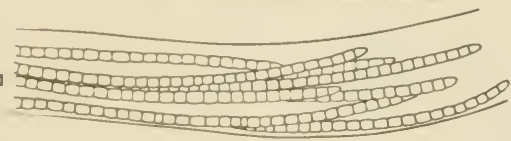

Figure 283
There are several species of this genus, differentiated by size and character of the apical cell. Unlike Hydrocoleum (Fig. 282) there are many intertwined trichomes in each sheath. Usually the trichomes show an active slithering motion over one another, may emerge from the end of the sheath and then retract. The thallus is often of macroscopic size as it grows on damp soil. Some species are more often found on submerged substrates, however. 
396a (394) Sheaths wide, containing 2 or 3 loosely arranged trichomes. Fig. $284 \ldots \ldots \ldots \ldots \ldots \ldots \ldots \ldots \ldots \ldots \ldots \ldots \ldots \ldots \ldots \ldots$. $\ldots \ldots \ldots$.

Fig. 284. Dasygloea sp.

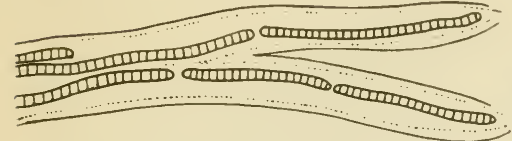

Figure 284

The sheaths of the plants in this genus are rather firm and definite in outline, contain but 1 to 3 trichomes. See D. amorpha Berk. The sheaths are usually forked or branched at the ends (as they are also in Schizothrix, Fig. 285, with which it should be compared). Only one species is reported from the United States.

396b Sheaths close, usually containing several crowded trichomes. Fig. 285 SCHIZOTHRIX

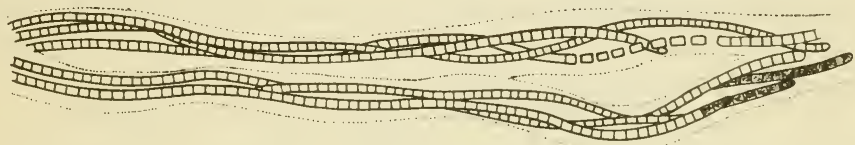

Figure 285

Fig. 285. Schizothrix tinctoria Gom.

In this genus theie are but few trichomes within a definite and rather firm sheath. The plant masses are of macroscopic size and often form streaming masses, or films and wefts over submerged vegetation. Several of the species quickly disintegrate when stored in a covered container for a short time without preservative and liberate a copious amount of the phycocyanin pigment which is present in blue-green algae. There are at least a dozen species reported from the United States, differentiated by size and cell proportions.

397 ( 381 ) Trichomes tapering from base to apex..............398

397b Trichomes not tapering from bàse to apex...........402

398a Filaments inclosed within abundant mucilage, forming a glabular or hemispherical body, attached or free-floating............399

398b Filaments not inclosed by abundant mucilage to form a thallus of definite shape,$\ldots \ldots \ldots \ldots \ldots \ldots \ldots \ldots \ldots \ldots \ldots 1$ 
399a Sheath containing 2 or more trichomes. Fig. 286...SACCONEMA Fig. 286. Sacconema rupes-

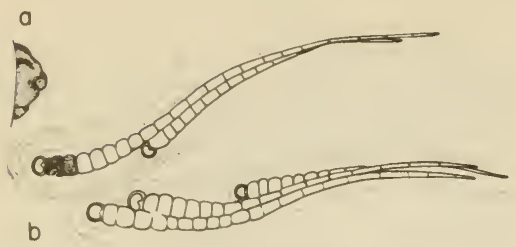

Figure 286 tre Borzi. $a$, habit of colony; $b$, filaments from colony.

Trichomes in this genus are tapering from a basal heterocyst as in Gloeotrichia (Fig. 287) but there is more than 1 trichome within a sheath and the gelatinous colony is very irregular in shape as it occurs on stones (sometimes in very deep water). The sheaths are wide, lamellate and are flaring at the outer end.

399b Sheath containing 1 trichome.....................400

$400 \propto$ With cylindrical spores adjoining a basal heterocyst; colonial mucilage soft in floating species, firm when attached to substrates and then forming hemispherical growth $1-3 \mathrm{~mm}$. in diameter. Fig. $287 \ldots \ldots \ldots \ldots \ldots \ldots \ldots \ldots \ldots \ldots$ GLOEOTRICHIA

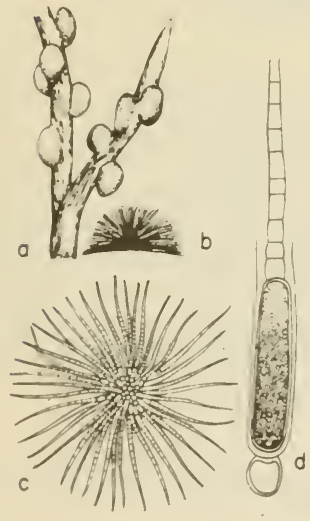

Figure 287

Fig. 287. a, Gloeothrichia Pisum (Ag.) Thur., habit on Ceratophyllum; b, diagram of filament arrangement; c, G. echinulata (J. E. Smith) P. Richter, diagram of filaments in colony; d, diagram of base of single filament showing heterocyst and spore.

In this genus the tapering trichomes are encased in mucilage which is usually soft (although firm in 1 species) and they are not so closely compacted as in Rivularia (Fig. 288), a genus which is very similar. Gloeotrichia produces filaments with large akinetes (spores) adjoining the basal heterocyst when mature. One of the most common species is the free-floating $G$. echinulata which occurs in abundance in some lakes and gives the appearance of the water being filled with tiny tapioca-like grains, buff-colored. G. natans (Hedw.) Rab. is also fairly common. It begins as an attached plant but late in the growing season it appears at the surface in brown gelatinous masses, either expanded and flat or irregularly globular. G. Pisum forms hard, green or black balls, 1 or $2 \mathrm{~mm}$. in diameter on submerged vegetation, sometimes completely covering the host plant. When plants in this genus are young the spores will not be present, in which case they may be confused with Rivularia (Fig. 288) which never produces spores, has a much harder colonial mucilage and has trichomes more densely packed, often parallel in arrangement. 
$400 \mathrm{~b}$ Spores absent; trichomes embedded in hard mucilage to form globular thalli which may coalesce, thus producing a continuous stratum; trichomes parallel and densely compacted or radiate. Fig. 288 .RIVULARIA

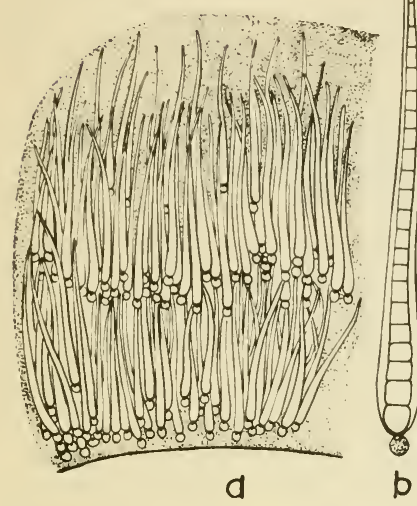

Figure 288

Fig. 288. Rivularia sp. a, diagram of portion of attached colony to show arrangement of filaments; $\mathrm{b}$, one filament showing basal heterocyst.

There are several species of this genus reported from the United States. They may be differentiated from Gloeotrichia by the hardness of the mucilage, the compactness of arrangement of the trichomes, and the absence of akinetes. Small globular balls or expanded masses of dark green mucilage occur on rocks or submerged logs, etc. Some b species grow in moist aerial surfaces, especially marine forms. Rivularia is not found free-floating, whereas Gloeotrichia (Fig. 287) usually is. See notes under the latter genus.

401a (398) Filaments branching freely; the basal portion of the branches lying within the sheath of the main filament for some distance, then diverging. Fig. $289 \ldots \ldots \ldots \ldots \ldots \ldots \ldots$ DICHOTHRIX

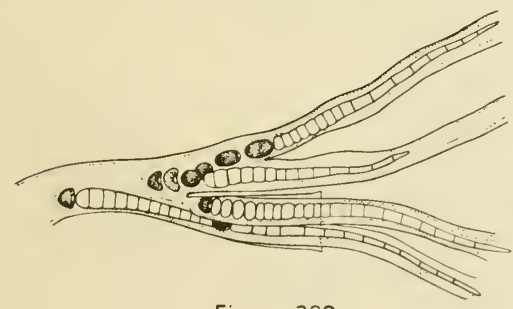

Figure 289

Fig. 289. Dichothrix gypsophila (Kuetz.) Bor. \& Flah.

In this genus the tapering trichomes are enclosed 2 or 3 together within branching sheaths. Brush-like tufts are produced by their habit of growth and these sometimes attain macroscopic proportions. The species are differentiated by size and sheath characters. They are customarily found intermingled with miscellaneous algae; are sometimes attached or at least adherent to aquatic plants.

40lb Filaments not branched (or seldom so); if branched, the branches not inclosed in the sheath of the main filament. See Fig. 275. 
$402 \alpha$ (397) Trichomes branching by lateral division of cells of the main axis (true branching)........................403

$402 \mathrm{~b}$ Tichomes unbranched, or with false branches (sections of trichome developing a series of cells to one side of a break in the

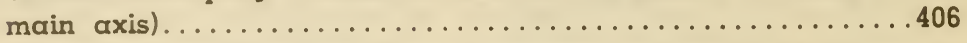

403a Individual trichome sheath not apparent; colony of trichomes invested by a mucilage; heterocysts usually on the ends of short branches. Fig. $290 \ldots \ldots \ldots \ldots \ldots \ldots \ldots \ldots$..................

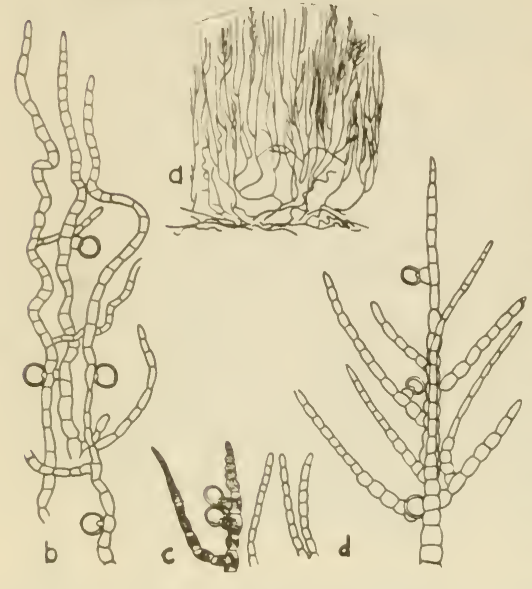

Figure 290

Fig. 290. Nostochopsis lobatus Wood. $a$, diagram of filament arrangement in colony; b-d, filaments and lateral heterocysts.

This is the only species reported from the United States. The filaments are composed of Anabaenalike cells and bear true branches. The heterocysts are borne laterally along the filaments or on the ends of short branches (rarely intercalary also). The filaments are colonial and are inclosed in a firm mucilage in the form of cylinders or hollow tubes which extend vertically from the bottom in quiet water, or lie horizontally in cur-

rents. In shallow water the gelatinous tubes may reach the surface and then broaden and flatten horizontally.

403b Individual trichome sheaths evident; heterocysts in the same series with the main axis, or cut off laterally from them but not on the ends of branches..........................404

404a Filaments closely aggregated, forming an attached, gelatinous thallus $1-2 \mathrm{~mm}$. in diameter. Fig. $291 \ldots \ldots \ldots \ldots$ CAPSOSIRA

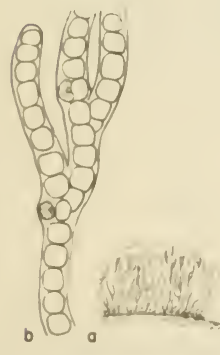

Figure 291

Fig. 291. Capsosira Brebissonii Kuetz. a, habit of attached colony; $b$, portion of filament showing lateral heterocysts. The sheath is thin and soft without a definite limiting membrane.

This species builds small bulbous mucilaginous colonies attached to the substrate. The individual trichomes which bear true branches are surrounded by a definite sheath which is yellowish. Heterocysts are usually lateral, but may be intercalary in the trichomes which do not taper toward the apices. There is but 1 species reported from widely separated stations in the United States. 
404b Filaments not forming $\alpha$ definitely shaped gelatinous thallus, but spreading irregularly.........................405

405a Filaments with more than I series of cells within $\alpha$ wide gelatinous sheath; heterocysts small, cut off laterally from the vegetative cells. Fig. $292 \ldots \ldots \ldots \ldots \ldots \ldots \ldots \ldots \ldots \ldots$. . . . . . . . . . .

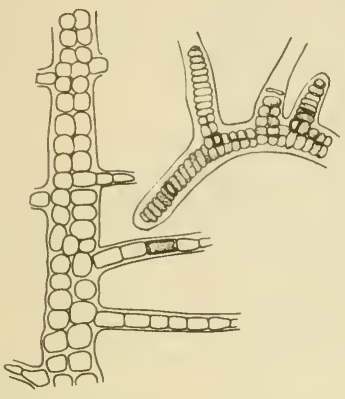

Figure 292

Fig. 292. a. Stigonema muscicola Borzi (Fischerella muscicola (Thur.) Gom.); b, S. turfaceum (Berk.) Cook.

Although there are several species reported from the United States, S. turfaceum, and S. ocellatum (Dillw.) Thur. are by far the most common. The latter is one which frequently does not show the multiseriate arrangement of cells. The sheath is wide and mucilaginous and in some species is distinctly lamellate. The heterocyst typically is cut off laterally from a vegetative cell. S. ocellatum shows intercellular connections. These species form brownish or blue-green growths on submerged reed stems, on exposed roots, and on other aquatic vegetation, or they may occur as velvety growths on moist soil, rocks, or concrete. Stigonema ocellatum invariably is found in acid water (desmid) habitats.

405b Filaments with cells in 1 series within a narrow sheath; heterocysts within the series of vegetative cells (intercalary). Fig. 293. HAPALOSIPHON

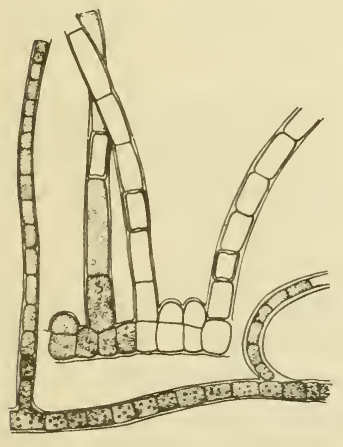

Figure 293

Fig. 293. Hapalosiphon hibernicus West \& West.

This genus is differentiated from Stigonema (Fig. 292) principally by the fact that the cells are always arranged in a single series with the heterocyst (usually somewhat rectangular) intercalary rather than lateral. Species are differentiated mostly by size and by habit of growth, some sprawling irregularly over a substrate, others branching more regularly and erect. Whereas Stigonema cells are usually rounded or oval and sometimes show intercellular connections, those of Hapalosiphon are ordinarily quadrate or quadrangular-globose and more compactly arranged within a close, thinner sheath. 
406a (402) Trichomes unbranched

406b Trichomes with false branches

407a Individual trichome sheath firm and definite; heterocyst basal (rarely intercalary heterocysts also). Fig. 294....MICROCHAETE

Fig. 294. a, Microchaete diplosiphon Gom.; b, M. robusta Setch.

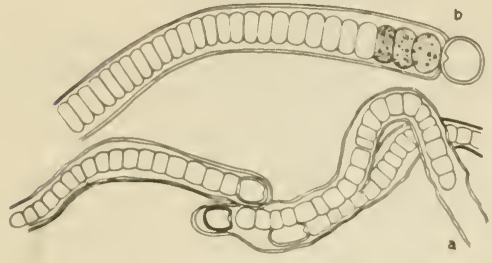

Figure 294 \& Gard.

Plants of this genus are mostly epiphytic, with part of the filament lying parallel with the substrate and then curving away. The filaments do not taper (or scarcely so) and although there may be intercalary heterocysts they usually are basal. There are 4 species described from the United States.

$407 \mathrm{~b}$ Individual sheath soft, often indistinct and intermingled with colonial mucilage; heterocysts either all terminal or all intercal.

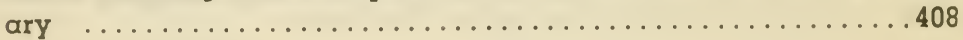

408a Heterocysts terminal 409

408b Heterocysts intercalary

409a Spores adjacent to the heterocysts which usually are at one end of the trichome. Fig. 295............CYLINDROSPERMUM

Fig. 295. a, Cylindrospermum majus

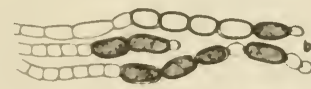

000000000000000

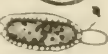

Figure 295

Kuetz.; b, C. marchicum Lemm.

The chief characteristic of this genus is the location of the heterocysts and spores, always terminal and usually only at one end of the trichome which does not taper at the extremeties. The plants form gregarious patches or films over submerged vegetation. The spores are formed singly or in series just back of the heterocyst. Frequently a dense 'nest' of spores will be found left where there has been a colony of filaments. Some species are terrestrial. 
409b Spores not adjacent to the heterocysts; heterocysts at both ends of the trichome. Fig. $296 \ldots \ldots \ldots \ldots \ldots \ldots$...........

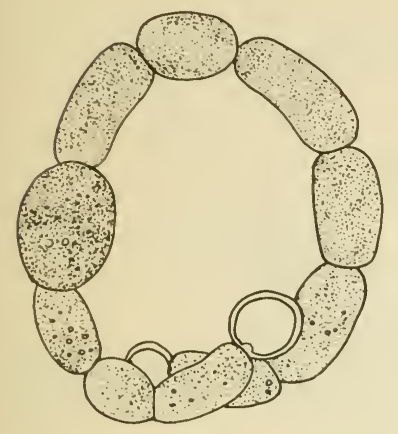

Figure 296
Fig. 296. Anabaenopsis Elenkinii Miller. (Redrawn from Smith).

There are 3 species of this genus reported from the plankton in the United States. The trichomes are usually relatively short and are coiled.

410a (408) Thallus composed of many trichomes; usually parallel within colonial mucilage...........................

$410 \mathrm{~b}$ Plant a solitary trichome, or if aggregated, not parallel, but entangled within colonial mucilage..................413

41la Trichomes inclosed in abundant mucilage: arranged to form a hollow, attached tubular thallus. Fig. 297.........WOLLEA

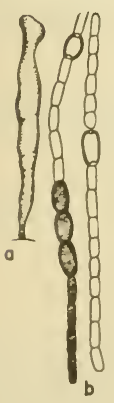

Fig. 297. Wollea saccata (Wolle) Born. \& Flah. a, habit of colony; $b$, trichomes in detail showing heterocysts, and akinetes in a series.

The filaments of this species lie more or less parallel in long, gelatinous, tube-like or sac-like thalli which grow vertically from the bottom in standing water. The cells are barrel-shaped or Anabaena-like, and the intercalary heterocysts are cylindrical or nearly so.

Figure 297

$411 \mathrm{~b}$ Thallus not a gelatinous tube 
412 a Trichomes parallel, forming a free-floating flake or bundle, containing a single heterocyst and a spore near the middle of each trichome. Fig. $298 \ldots \ldots \ldots \ldots \ldots \ldots \ldots$. APHANIZOMENON

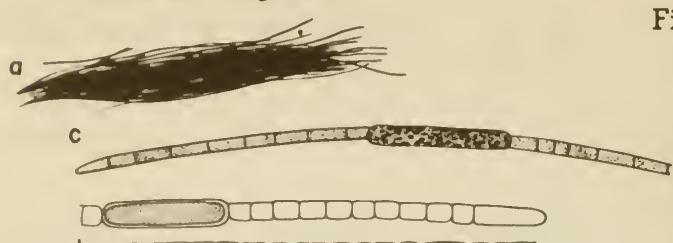

Fig. 298. Aphanizomenon flos-aquae (L.) Ralfs. $a$, diagram of colony; $b$, a few trichomes from the colony; c-d, trichomes in detail showing medially located cylindrical akinete.

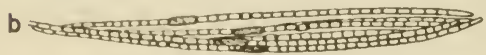

Figure 298

This is the only common species reported from this country and is very widely distributed in lakes which are rich in nitrogen and phosphorus. The trichomes lie in parallel bundles and form flakes of macroscopic size. Because of the gas vacuoles (pseudovacuoles) the plants float high in the water and form surface scums and mats. Hence they are able to cause serious trouble in lakes and reservoirs used for water supplies and pleasure resorts. During summer months the species may develop a "bloom" condition and be so abundant as to give the water the appearance of "pea soup." Considerable economic loss is suffered as a result of the disturbance caused by Aphanizomenon when it leads to the death of fish. It is a plant that usually accompanies human settlement about lakes and rarely is the plant found in abundance in lakes remote from habitation.

412b Trichomes not parallel, or if so, forming indefinitely shaped flakes. See Fig. 271 (in part)...................... ANABAENA

$413 \alpha(410)$ Trichomes planktonic, solitary ................414

$413 \mathrm{~b}$ Trichomes colonial, in a gelatinous mass.............415 414a Vegetative cells and heterocysts disc-shaped, wider than long.

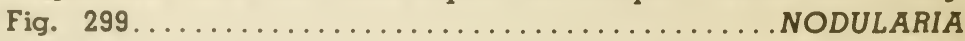

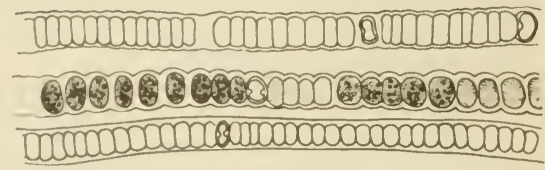

Figure 299

Fig. 299. Nodularia spumigena Mert.

Filaments of this species are at once distinguishable by the very short, compressed vegetative cells and heterocysts. The sheath is rather thin and mucilaginous and sometimes is not immediately apparent. The species illustrated is the most common of the 4 that are reported from the United States. Plants of this genus are usually found intermingled with miscellaneous algae from the tychoplankton. 
414b Cells globose to cylindric, or barrel-shaped, not compressed as above. See Fig. $271 \ldots \ldots \ldots \ldots \ldots \ldots \ldots \ldots$. ANABAENA

415a (413) Plant mass definite in shape, usually globular, bound by $\alpha$ firm, gelatinous tegument; colonies microscopic or macroscopic.

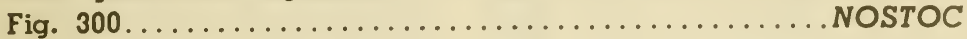

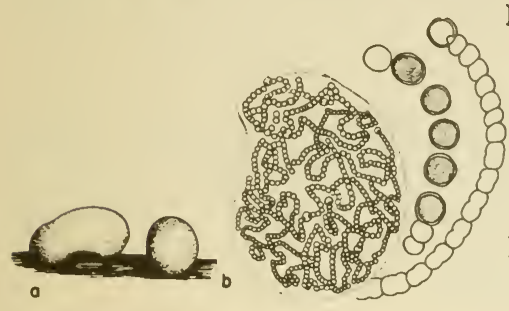

Figure 300

Fig. 300. a, Nostoc pruniforme Ag., showing habit of colonies; $\mathrm{b}, N$. linckia (Roth) Bor. \& Flah., with two trichomes in detail showing heterocyst and akinetes.

This genus is characterized chiefly by the firm outer tegument of the mucilaginous material in which numerous bead-like filaments are inclosed, thus giving the thallus a definite form. One species forms colonles as large as a goose egg, whereas another, N. commune Vauch., builds tough, membranous green or brown layers on the bottoms of pools or in swampy places, sometimes in wet alpine meadows. $N$. pruniforme is a very common species which forms marble- or acornsized colonies on damp soil, often among grasses in marshy meadows. The globular or oval thalli are frequently mistaken for turtle or some other type of reptilian egg. $N$. amplissimum Gard. is known as Mare's Eggs in the far West where it produces colonies $10 \mathrm{~cm}$. in diameter.

415b Plant mass not definite in shape: mucilage soft, not bounded by a firm tegument.............................

416a Trichomes forming small bundles within $\alpha$ gelatinous sheath, either entangled or parallel. Fig. $301 \ldots \ldots \ldots \ldots \ldots$ AULOSIRA

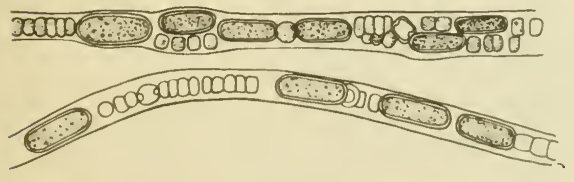

Figure 301

Fig. 301. Aulosira laxa Kirch.

This species (the only one of the genus found in the United States) is much like Microchaete (Fig. 294) and the genus is sometimes classified with it. Some authorities differentiate it on the basis of the soft sheath, the intercalary heterocysts, and the akinetes which occur intercalary and of the same size and proportions as the heterocysts.

416b Trichomes not forming bundles. See Fig. 271..... ANABAENA 
417a (406) Branches arising in pairs about midway between 2 heterocysts (branching rarely solitary). Fig. $302 \ldots \ldots$.... SCYTONEMA

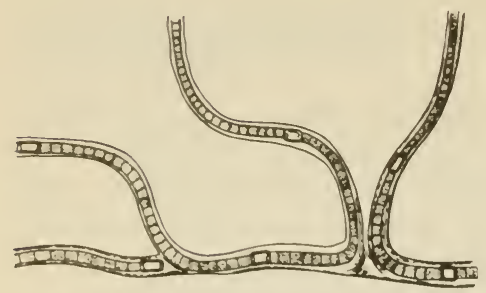

Figure 302

Fig. 302. Scytonema Archangelii Born. \& Flah.

There are several species of this genus which are very common. Although some branch rather seldom, most of them show numerous false branches which arise singly or in pairs between the heterocysts. They are plants of both aquatic and subaerial habitats. Species are differentiated by size, shape of cell, and sheath characters.

417b Branches arising singly just below a heterocyst or a series of them; (branching sometimes rare and not definite, requiring a search through a number of plants to determine this character). .418

418a Sheath close and firm, 1 trichome in a sheath. .419

418b Sheath usually wide and soft; at least more than 1 trichome within a sheath.

419a Branches frequent, arising just below the heterocysts which are always intercalary. Fig. $303 \ldots \ldots \ldots \ldots \ldots \ldots$. TOLYPOTHRIX

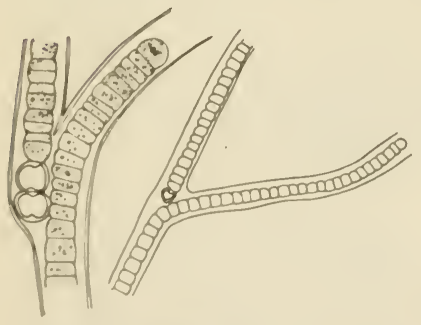

Figure 303

Fig. 303. Tolypothrix distorta Kuetz.

This genus is differentiated from Scytonema (Fig. 302) principally by the fact that the false branch always arises below a heterocyst or sometimes below a series of them. There are several species that are common, differentiated by size and by sheath characters, some of which are thick and lamellate, others thin and soft.

419b Branches rare; heterocysts terminal (rarely intercalary also). See Fig. 294 MICROCHAETE 
420a (418) Trichomes parallel within a fairly wide sheath; plant mass doveloping bushy tufts; heterocysts basal in the trichome. Fig. 304 DESMONEMA

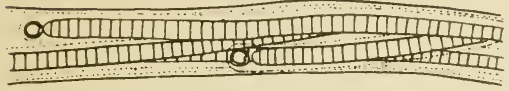

Figure 304

Fig. 304. Desmonema Wrangelii (Ag.) Born. \& Flah.

The falsely branched filaments of this species differ from others in the Scytonemataceae by having several trichomes within 1 sheath. The filaments are gregarious and form plant masses of macroscopic size on moist aerial substrates, and usually show erect tufts. This is the only species reported from the United States.

420b Trichomes twisted and entangled in a wide sheath; heterocysts intercalary. Fig. $305 \ldots \ldots \ldots \ldots \ldots \ldots \ldots \ldots$. DIPLOCOLON

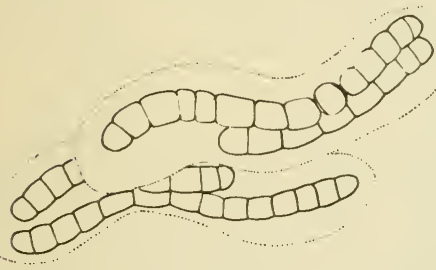

Figure 305

Fig. 305. Diplocolon Heppii Naeg. (Redrawn from Smith).

This plant forms an expanse on moist aerial substrates such as dripping rocky cliffs. The trichomes are falsely branched, have intercalary heterocysts and are inclosed several together in a wide gelatinous sheath.

421a (376) Plants attached; cells club-shaped or with other shapes, gregarious, forming cushion-like masses or horizontal expanses, or solitary; epiphytic or growing on shells; cells usually showing endospores (segments of the protoplast rounded up and forming reproductive bodies which are spore-like) . . . . . . . . . 422

421b Plants not attached; cells mostly spherical, hemispherical, or rodshaped, not forming cushion-like masses nor horizontal expanses; endospores lacking 
422a Cells erect, subcylindrical clubs, straight or curved: epiphytic; endospores cut off successively at the tips of cylindrical proto-

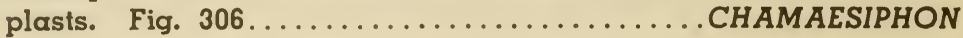

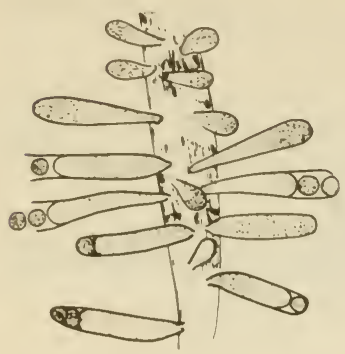

Figure 306

Fig. 306. Chamaesiphon incrustans Grunow.

These club-shaped or cylindrical plants grow as epiphytes on filamentous algae and whereas they may be solitary they usually occur in gregarious patches. When mature the end of the protoplast cuts off rounded-up spores, "endospores" which float away as regenerative elements.

422b Cells some other shape: gregarious, forming horizontal expanses

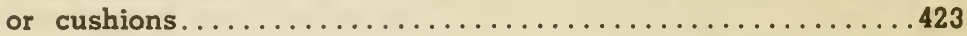

423a Perforating shells, forming short irregular, spreading filaments (filamentous character not clearly evident). Fig. 307.....HYELLA

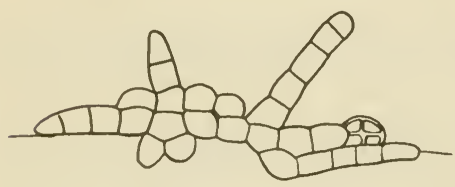

Figure 307

Fig. 307. Hyella fontana Huber \& Jadin.

Most species of this genus are marine but some occur in fresh water, boring into shells of molluscs. The plant is a short, irregularly branched filament, sometimes forming a cushion-like mass. The substrate must be treated with dilute acetic acid to dissolve away the lime before the plants can be studied satisfactorily.

423b Not perforating shells; plant mass expanded or cushion-like. .424

424a Plant mass composed of cells arranged in 1 layer. Fig. 308... . XENOCOCCUS

Fig. 308. Xenococcus Schousbei Thur.

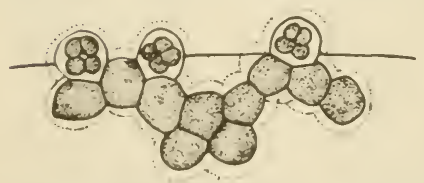

Figure 308

There are at least 2 species of this genus found in the fresh waters within the United States, most forms being marine. They occur as patches of blue-green cells, compactly arranged as epiphytes on filamentous algae. Cells form endospores although they may reproduce actively by fission. 
424b Plant mass in the form of a cushion with cells arranged in vertical rows

425a Cells surrounded by a sheath; plant mass thick, cartilaginous, usually macroscopic. Fig. 309.............CHONDROCYSTIS

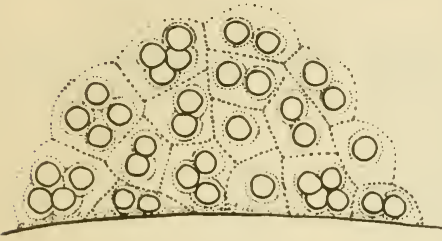

Figure 309

Fig. 309. Chondrocystis Schauinslandii Lemm.

This species forms extensive, cushionlike masses on exposed surfaces and are heavily encrusted with lime. The colonial mass is inclosed by a tough mucilage in which 'families' of cells are surrounded by individual sheaths. This is the only species in the genus and seems to have been reported but a few times from the United States.

425b Cells not inclosed by a thick sheath; plant mass macroscopic. . 426

426a Plant mass forming a flat, encrusting layer; cells forming short, erect unbranched filaments. Fig. $310 \ldots \ldots \ldots \ldots$ PLEUROCAPSA

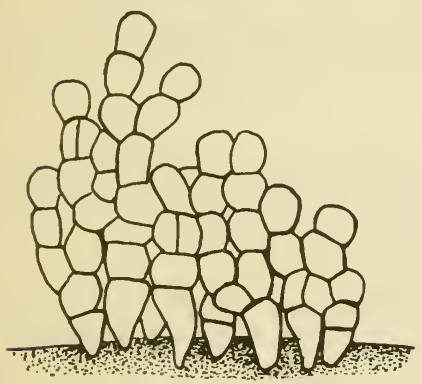

Figure 310

Fig. 310. Pleurocapsa minor Hansg.

In this genus the plant mass is essentially filamentous but the cells are so closely appressed that the branching habit cannot be determined easily without dissecting. Encrusting thralli are produced with some differentiation between the lower or inner cells and those near the surface which produce the endospores.

426b Plant mass cushion-like; cells forming erect branched filaments. Fig. $311 \ldots \ldots \ldots \ldots \ldots \ldots \ldots \ldots \ldots \ldots \ldots \ldots \ldots \ldots$ ONCOBYRS $A$

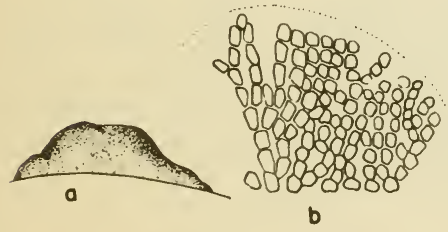

Figure 311

Fig. 311. Oncobyrsa sp. $a$, habit of colony; $b$, diagram of cell arrangement. Oncobyrsa rivularis is the most common species of this genus. It has compactly arranged series of cells in which the filamentous plan can be more easily. determined than in Pleurocapsa (Fig. 310). The thallus is a mound of cells, encased in a tough mucilage on filamentous algae. Although the general habit is that of members of Chamaesiphonaceae, there have been no endospores observed. 
427a (421) Cells globose, or hemispherical because of recent cell division .............................. 428

427b Cells some other shape.

428a Cells inclosed in mucilage and bearing a long gelatinous hair. See Fig. 206......................... GLOEOCHAETE

428b Cells not in $\alpha$ sheath which bears $\alpha$ hair.

429a Protoplasts occurring as bright blue-green, vermiform bodies, radiately arranged or scattered within Oocystis-like cells (see Oocystis, Fig. 85), inclosed by mother-cell wall. See Fig. 208.

.GLAUCOCYSTIS

429b Cells not as above..........................430

430a Cells solitary or grouped in small families of 2-4-8 (rarely as many as 16) individuals, if more than 16, then in a flat plate.

$430 \mathrm{~b}$ Cells aggregate in larger numbers, inclosed by a mucilaginous

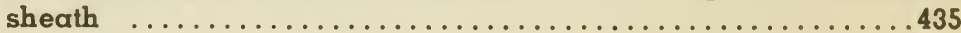

43la Cells solitary or in pairs, without a gelatinous sheath. Fig. 312 . SYNECHOCYSTIS

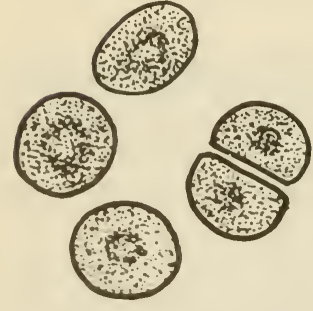

Figure 312

Fig. 312. Synechocystis aquatilis Sauv.

This is a rather rare species which is probably of more common occurrence than is evidenced by the records of it from this country. There are globular cells, solitary or in pairs, without a mucilaginous sheath being apparent. The densely granular 'central' body of the cells is more complex than for other genera in the Chroococcaceae.

$431 \mathrm{~b}$ Cells inclosed by a mucilaginous sheath (sometimes indistinct). 
$432 \alpha$ Cells arranged in rectilinear series to form a flat plate. Fig. 313. MERISMOPEDIA

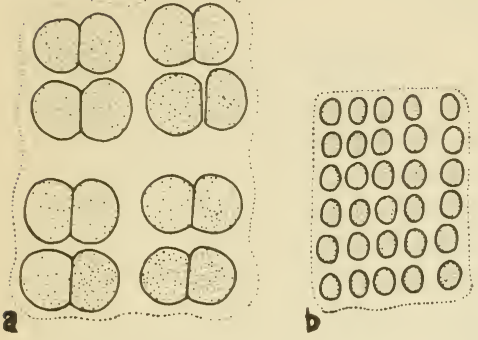

Figure 313

Fig. 313. a, Merismopedia elegans var. major G. M. Smith; b, M. glauca (Ehr.) Naeg.

There are several species on record from the United States, differentiated by cell shape, color, and presence of vacuoles. The genus is easily distinguishable by the definite arrangement of the cells in rectilinear series. M. convoluta Breb. is an uncommon species which has relatively large plates that are enrolled at the margin.

432b Cells not arranged in rectilinear series..............433

$433 \alpha$ Cells heart-shaped or round, occurring at the ends of radiating strands of mucilage (focus down into the colony and cut down illumination to detect presence of radiating strands). Fig. 314. GOMPHOSPHAERIA

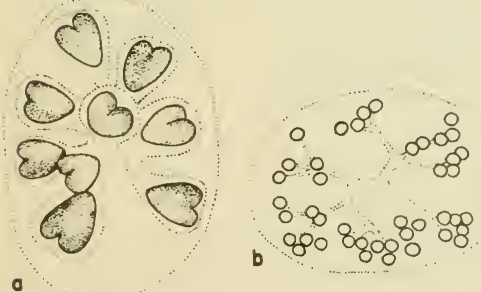

Figure 314
Fig. 314. a, Gomphosphaeria aponina Kuetz.; b, G. lacustris Chod.

These plants are characterized by having cells in globular colonies, closely or distantly arranged at the ends of mucilaginous strands that radiate from the center of the thallus. G. lacustris is frequently found in the euplankton, whereas G. aponina occurs mostly in the tychoplankton.

$433 \mathrm{~b}$ Cells not at the ends of radiating strands.............434 
434 $\alpha$ Groups of cells inclosed in concentric layers of mucilage; colonial investment intermingling (confluent) with sheaths of other groups and so forming gelatinous masses, mostly on moist substrates: sheaths showing definite concentric rings. Fig. $315 \ldots \ldots \ldots \ldots$

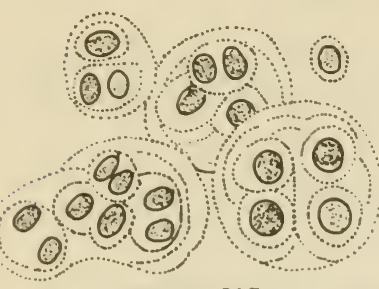

Figure 315

Fig. 315. Gloeocapsa punctata Naeg.

This is a genus in which globular cells are inclosed, many 'families' together within gelatinous masses of considerable size. A common habitat is the surface of moist rocks and cliffs, soil in greenhouses, moist cement work, etc. Cells, pairs of cells, or clusters of cells are inclosed in concentric layers of mucilage. Many species, especially when few cells are involved, can scarcely be differentiated from Chroococcus (Fig. 316) and there is a disposition among some specialists to place the two genera together.

434b Colonial mucilage not intermingling with that of other colonies: families of cells separated from one another, usually free-floating but commonly inhabiting soil and moist substrates in aerial situations; colonial sheath usually without conspicuous concentric rings. Fig. $316 \ldots \ldots \ldots \ldots \ldots \ldots \ldots \ldots \ldots \ldots \ldots$ CHROOCOCCUS
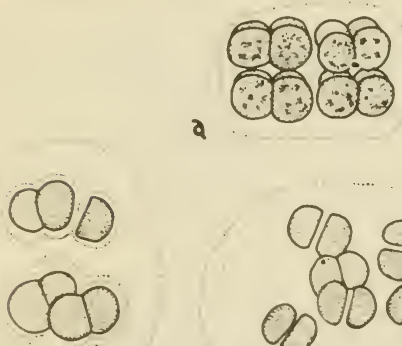

b

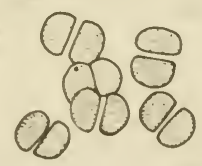

Fig. 316. $a$, Chroococcus Prescottii Drouet \& Daily; b, C. limneticus var. distans G. M. Smith; c, C. limneticus Lemm.

There are numerous species in this genus, many of them inadequately described and differentiated. The genus is separated from Gloeocapsa (Fig. 315) mostly on the basis of the fewness of cells involved in a colony and by the

fact that 'families' of cells are not Figure 316 all inclosed in a common lamellated mucilaginous matrix. The colonies are usually composed of no more than 16 cells and more commonly of but 4,8 or 12 cells. $\AA$ few species are definitely planktonic but others occur attached to aquatic substrates or form films on aerial surfaces. C. turgidus (Kuetz.) Naeg. is a large species in which cells occur in 2's and 4's within a stratified envelope and is one that is invariably found in desmid habitats where the water is acid.

$435 \alpha(430)$ Cells arranged to form a flat plate............436

435b Cells forming irregularly globular or oval colonies.......437 
436a. Cells arranged in rectilinear series. See Fig. $313 \ldots \ldots \ldots \ldots$ MERISMOPEDIA 436b Cells irregularly arranged. Fig. 317 HOLOPEDIUM

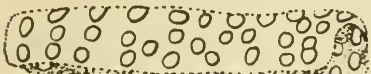
0000000 $0000800808 \%$ $080080088880^{\circ}$ $888000008 \%$ 00000880000 10000000 88800

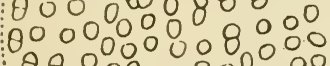
$\theta \theta 0000080000$ 0000000000008

Fig. 317. Holopedium irregulare Lag.

This genus differs from Merismopedia by having the cells irregularly arranged within a gelatinous plate. Only this species has been reported for the genus from the United States.

Figure 317

437 $\alpha$ (435) Colony globular, rather definite in shape..........438 437b Colony irregular in outline.................... 440 $438 \alpha$ Cells very numerous and crowded within the colonial mucilage (usually showing false vacuoles which refract the light so that the cells appear brownish, black or purplish). Fig. 318 .

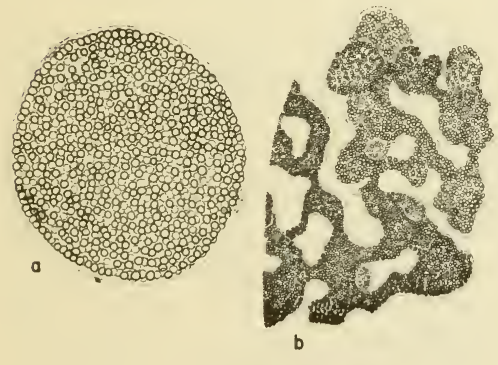

Figure 318

Fig. 318. a, Microcystis flos-aquae (Wittr.) Kirch.; b, M. aeruginosa Kuetz. emend Elenkin.

The marble-like cells of this genus are closely compacted and irregularly arranged in definitely shaped but irregular colonies inclosed in mucilage. $M$. flosaquae has more nearly globular and symmetrically shaped colo. nies than $M$. aeruginosa. The cells often contain pseudovacuoles (gas pockets) and float high in the water. Hence they produce surface scums and like Aphanizomenon (Fig. 298) cause a great deal of disturbance in lakes and reservoirs. Dense growths may lead indirectly to the death of fish through suffocation. It is rather curious that where these species occur (especially $M$. aeruginosa) the water is completely dominated by the plant to the exclusion of almost all other forms. It has often been noted that a lake may be densely overgrown with either Microcystis or with Aphanizomenon, but not the two together. There are several species of the genus differentiated by size and by details of the sheath structure, and by form of colony. 
438b Cells not densely crowded but evenly spaced or regularly arranged

439a Cells in one layer at the periphery of the mucilage. Fig. 319. COELOSPHAERIUM

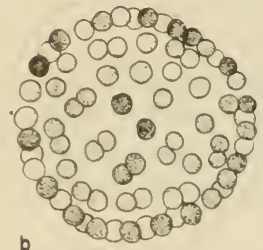

Figure 319

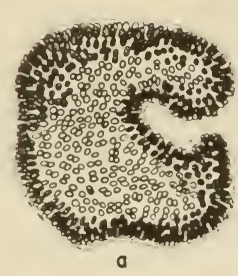

c

Fig. 319. a, Coelosphaerium Naegelianum Unger; b, C. Kuetzingianum Naeg.

There are 2 common species of this genus which are members of the open water plankton. As the name suggests, the cells are arranged so as to form a hollow colony. C. Naegelianum has cells which contain pseudovacuoles which are light refractive and the colony appears brownish-purple or even black rather than blue-green when seen microscopically.

439b Cells distributed throughout the colonial mucilage. Fig. $320 \ldots$ APHANOCAPSA

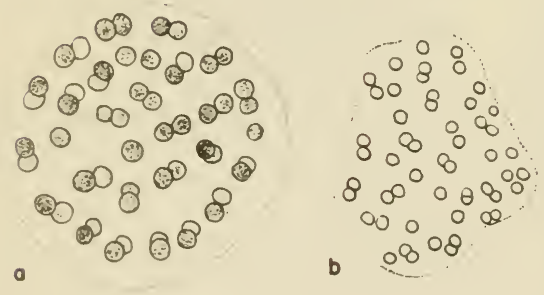

Figure 320

Fig. 320. a, Aphanocapsa Grevillei (Hass.) Rab.; b, A. elachista West \& West.

Whereas Microsystis has cells compactly arranged, in this genus they are rather evenly spaced throughout the colonial mucilage. The cells are spherical and vary in size in different species, some being not much larger than bacteria and can be mistaken for them. Cells often appear in pairs. There are several species reported from the United States.

440a (437) Cells crowded, usually with refractive false vacuoles. See Fig. $318 \ldots \ldots \ldots \ldots \ldots \ldots \ldots \ldots \ldots \ldots \ldots \ldots \ldots \ldots \ldots \ldots$ MICROCYSTIS

440b Cells evenly spaced within the mucilage; false vacuoles lacking.

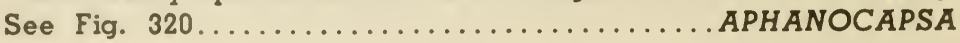


441a (427) Cells quadrangular, arranged in flat plates. Fig. $321 \ldots$ TETRAPEDIA

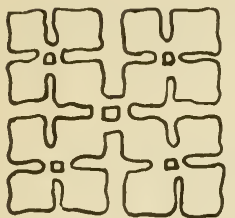

Figure 321

Fig. 321. Tetrapedia sp., diagram showing arrangement of rectangular cells.

Tetrapedia Reinschiana Arch. is a rare plant that has quadrangular cells arranged in multiples of 4 to form a flat rectangular plate. One other species has been reported from the United States, occurring in the plankton.

44lb Cells some other shape.

$442 \alpha$ Cells solitary or in colonies of few cells, up to $32 \ldots \ldots \ldots 443$

442b Cells numerous within a globular or amorphous gelatinous matrix. .448

$443 \alpha$ Without a gelatinous sheath. Fig. 322......SYNECHOCOCCUS

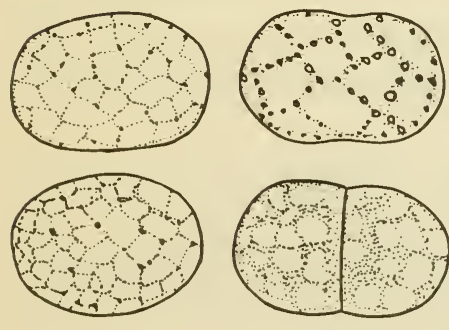

Figure 322

Fig. 322. Synechococcus aeruginosus Naeg.

This is a solitary unicell which does not possess a gelatinous sheath. Cells may be in pairs as a result of recent fission. They are relatively large for Cyanophyta (may be up to 35 microns in length) and are often conspicuous in the microscope mount because of their briaht blue color.

443b With a gelatinous sheath (sometimes discerned with difficulty), or inclosed by a gelatinous matrix.................444 
444a Cells elongate; pointed at the ends. Fig. 323

DACTYLOCOCCOPSIS

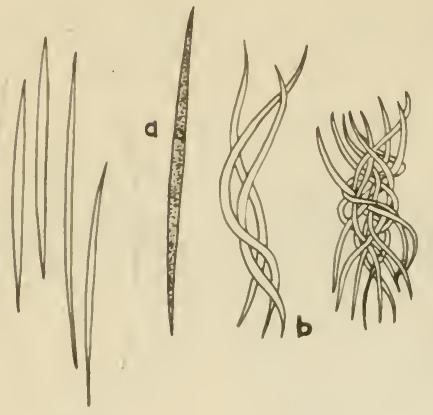

Fig. 323. a, Dactylococcopsis acicularis Lemm.; b, D. fascicularis Lemm.

These are fusiform shaped cells arranged with their long axes mostly parallel with that of the fusiform-shaped colonial envelope. Two species are known from this country, occurring in the plankton.

Figure 323

444b Cells not pointed at the ends. 445

445a Cells heart-shaped, at the ends of radiating strands of mucilage; colonies globular. See Fig. $314 \ldots \ldots \ldots \ldots$ GOMPHOSPHAERIA

445b Cells not at the ends of radiating strands .............446

446a Cells radiately disposed. Fig. $324 \ldots \ldots \ldots \ldots$ MARSSONIELLA

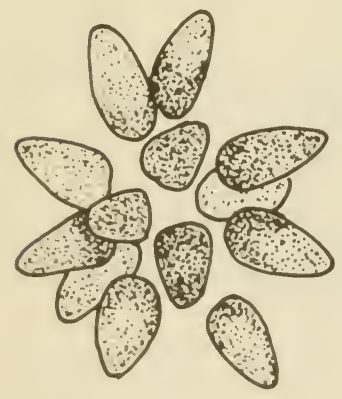

Fig. 324. Marssoniella elegans Lemm.

Figure 324

This species (the only one reported) has pear-shaped cells more or less definitely arranged about a common center with scarcely any evidence of a colonial mucilage. It is to be looked for in the plankton of open water.

$446 \mathrm{~b}$ Cells not radiately arranged 
447a Individual cell sheath distinct. Fig. $325 \ldots \ldots \ldots$. GLOEOTHECE

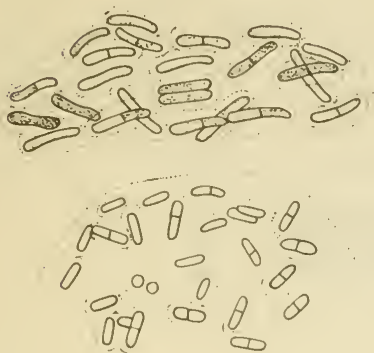

Figure 325

Fig. 325. Gloeothece linearis Naeg.

In this genus the cells are elongate cylinders or bacilliform in shape and are inclosed by individual sheaths all within a common mucilage. There are several species differentiated mostly by cell shape and size. Species should be compared with Aphanothece (Fig. 327).

447b Individual cell sheath not apparent. Fig. 326...RHABDODERMA

Fig. 326. Rhabdoderma lineare Schm. \& Lauterb.

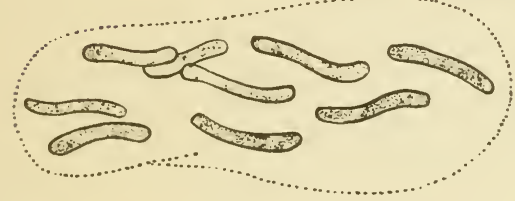

Figure 326

In this genus the cells are elongate and cylindrical, even vermiform and are much like Gloeothece except that there is no individual cell sheath. The plants occur in small colonies of 4,8 , or 16 in the plankton of lakes; is sometimes in the tychoplankton.

448a (442) Cells arranged at the periphery of a gelatinous matrix. See Fig. 319 COELOSPHAERIUM

448b Cells irregularly scattered throughout the colonial mucilage...449 449a Individual cell sheath not distinct. Fig. 327 ..... APHANOTHECE Fig. 327. Aphanothece Castagnei

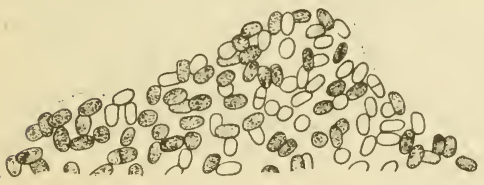

Figure 327 (Breb.) Rab.

Cells are elongate cylinders or bacilliform, occurring in large colonies up to $5 \mathrm{~cm}$. in diameter and have no individual sheaths. The colonies develop on the bottom of lakes but become free-floating and are often washed into shallow water along shore where they may form a 'soupy' mass of brownish or olive-green (rarely bluish) bodies. Macroscopically they appear much like Nostoc colonies (Fig..300) especially if the colonies are young and smooth in outline.

$449 \mathrm{~b}$ Individual cell sheath distinct. See Fig. $325 \ldots .$. GLOEOTHECE 
450a (345) Shells mostly circular or polygonal in outline (sometimes irregular), but with decorations (rows of dots, lines, etc.) which are concentrically arranged from a central point; raphe (distinct canal in wall in the median region) absent. Figs. 328 and 329. CENTRALES*

Fig. 328. Melosira granulata (Ehr.) Ralts.

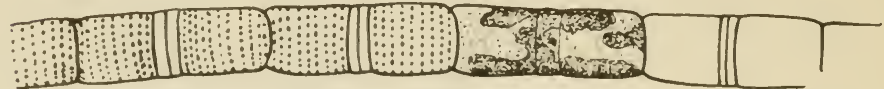

Figure 328

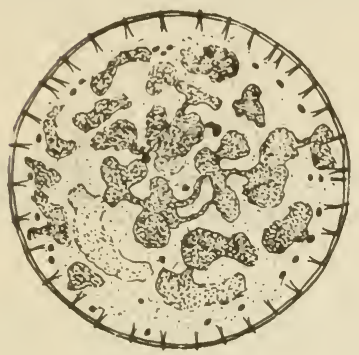

Figure 329

Fig. 329. Stephanodiscus niagarae Ehr.

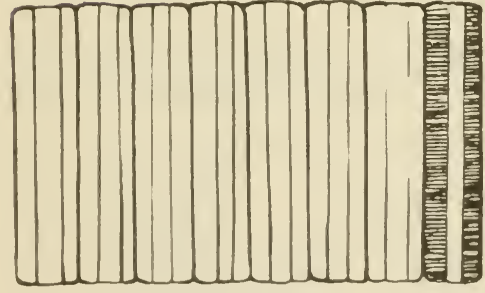

Figure 330
$450 \mathrm{~b}$ Shells mostly elongate, cigar-shaped, boat-s h a p ed, crescent-shaped, or rectangular, with decorations bilaterally arranged from longitudinal lines; raphe (distinct longitudinal canal in the wall in the median region) present or absent. Figs. 330 to $337 \ldots \ldots$. PENNALES *

Fig. 330. Fragilaria sp.

- In order to identify diatoms satisfactorily special technıques are required for preparing them for microscopical study, and a descriptive key must of necessity employ highly specialized terminolcgy. Space here does not permit the inclusion of all of the common diatom genera which occur in fresh water (which may number 50 or more). Hence a key which does not include all or most of them would be inadequate and actually misleading in many instances. A few of the more common genera, especially those found in the phytoplankton of lakes, are illustrated. 
Diatoms occur in innumerable species both in the plankton, on the bottom, and on submerged aquatics, etc. The cells should be cleaned by boiling in acid so as to remove all organic content in order to make the wall characters visible. Identification of genera and species is based largely upon the shape of the cell and upon the manner of decoration, the presence of septae in the cells, and upon other details which cannot be seen unless the shells are clear and free from chromatophores and oil droplets. Some are so characteristically shaped that the genus can be determined without this treatment. The most common genera in the plankton are Stephanodiscus, Melosira, Fragilaria, Asterionella, Navicula and Tabellaria. Stephenodiscus is shaped like a drum; has a crown of short spines just within the margin. Melosira is capsule-shaped, with the cells arranged end to end in filaments. Fragilaria commonly has long, narrow rectangular cells placed side by side to form flat ribbons. Tabellaria forms zig-zag chains. Navicula is commonly 'boat-shaped' or cigar-shaped when the cell is seen in valve (top) view. Asterionella has cells radiating from a common center in one plane.

Fig. 331. Tabellaria fenestrata (Lyngb.) Kuetz.

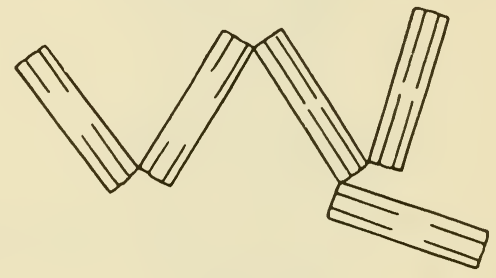

Figure 331

Fig. 332. Meridion circulare (Grev.) Ag.

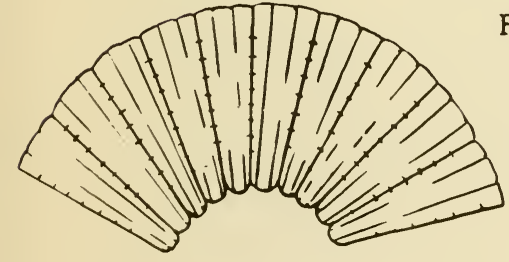

Figure 332

Fig. 333. Asterionella formosa Hass.

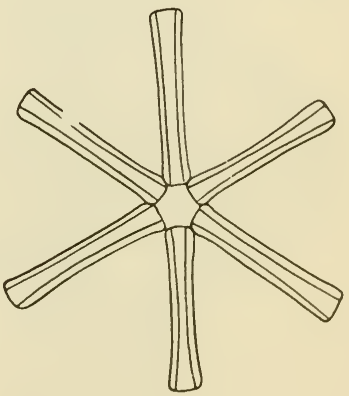


Fig. 334. Navicula sp.; $a$, top (valve) view; b, side (girdle) view.

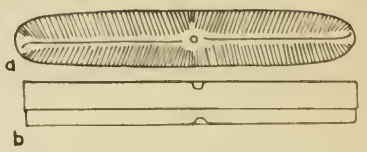

Figure 334

Fig. 335. Gomphonema sp.

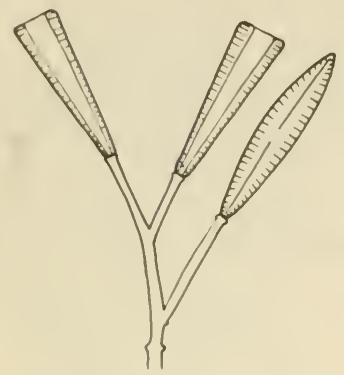

Figure 335

Fig. 336. Surirella splendida (Ehr.) Kuetz.

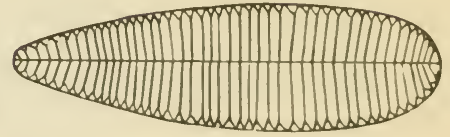

Fig. 337. Cocconeis Pediculus Ehr.

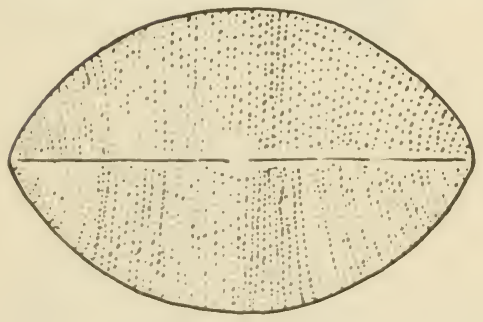

Figure 337 


\section{A CHECK LIST OF THE MORE COMMON GENERA OF FRESH-WATER ALGAE ACCORDING TO FAMILIES, ORDERS AND PHYLA}

\section{PHYLUM (DIVISION) CHLOROPHYTA}

A. SUB-DIVISION CHLOROPHYCEAE

1. Order Volvocales

Family Polyblepharidaceae

Dunaliella

p. 36, fig. 32

Polyblepharides

p. 35 , fig. 29

Pyramimonas

p. 35 , fig. 30

Stephanoptera

p. 35 , fig. 31

Family Chlamydomonadaceae

Carteria

p. 31, fig. 21

Chlamydomonas

p. 34 , fig. 27

Chlorogonium

p. 33 , fig. 25

Lobomonas

p. 33 , fig. 26

Platymonas

p. 31, fig. 20

Sphaerellopsis

p. 34 , fig. 28

Family Phacotaceae

Phacotus

p. 32 , fig. 23

Pteromonas

p. 33, fig. 24

Scotiella

p. 84 , fig. 127

Wislouchiella

p. 32 , fig. 22

Family Volvocaceae

Eudorina

p. 29 , fig. 17
Gonium

p. 26 , fig. 10

Pandorina

p. 28 , fig. 14

Platydorina

p. 26 , fig. 9

Pleodorina

p. 30 , fig. 18

Volvox

p. 28 , fig. 15

Family Spondylomoraceae

Chlamydobotrys

p. 27, fig. 13

Pascheriella

p. 27, fig. 11

Spondylomorum

p. 27 , fig. 12

Family Sphaerellaceae

Haematococcus

p. 30 , fig. 19

Stephanosphaera

p. 29 ; fig. 16

2. Order Tetrasporales

Family Palmellaceae

Asterococcus

p. 46, fig. 51

Dispora

p. 49 , fig. 58

Gloeocystis

p. 41 , fig. 41

Hormotila

p. 99, fig. 154

Palmella

p. 38 , fig. 36

Palmodictyon

p. 43 , fig. 45

Sphaerocystis

p. 48 , fig. 54 


\section{Urococcus}

p. 82 , fig. 124

Family Tetrasporaceae

Apiocystis

p. 39 , fig. 37

Schizochlamys

p. 45 , fig. 48

Tetraspora

p. 38 , fig. 35

Family Chlorangiaceae

Chlorangium

p. 52 , fig. 63

Malleochloris

p. 67, fig. 95

Prasinocladus

p. 100 , fig. 156

Stylosphaeridium

p. 67, fig. 96

Family Coccomyxaceae

Chlorosarcina

p. 37 , fig. 34

Coccomyxa

p. 40 , fig. 39

Dactylothece

p. 44 , fig. 47

Elakatothrix

p. 39 , fig. 38

Nannochloris

p. 78 , fig. 116

Ourococcus

p. 64 , fig. 89

3. Order Ulotrichales

Family Ulotrichaceae

Binuclearia

p. 105 , fig. 164

Geminella

p. 106 , fig. 165

Hormidiopsis

p. 105, fig. 163

Hormidium

p. 107, fig. 168

Radiofilum

p. 106, fig. 166

Stichococcus

p. 104, fig. 162

Ulothrix

p. 107 , fig. 167
Uronema

p. 108 , fig. 169

Family Microsporaceae Microspora

p. 109, fig. 172

Family Cylindrocapsaceae

Cylindrocapsa

p. 108, fig. 170

Family Chaetophoraceae

Aphanochaete

p. 104, fig. 161

Chaetonema

p. 113, fig. 178

Chaetopeltis

p. 114, fig. 179

Chaetophora

p. 122 , fig. 196

Chlorotylium

p. 117, fig. 186

Draparnaldia

p. 123, fig. 197

Draparnaldiopsis

p. 123

Entocladia

p. 112, fig. 175

Microthamnion

p. 120, fig. 191

Protoderma

p. 114 , fig. 180

Pseudoulvella

p. 115, fig. 181

Pseudochaete

p. 112, fig. 176

Stigeoclonium

p. 113, fig. 177

Ulvella

p. 115 , fig. 182

Family Protococcaceae

Protococcus

p. 53 , fig. 66

Family Coleochaetaceae

Chaetosphaeridium

p. 51, fig. 62

Coleochaete

p. 97 , fig. 150

Dicranochaete

p. 51 , fig. 61 
HOW TO KNOW THE FRESH.WATER ALGAE

Family Trentepohliaceae

Cephaleuros

p. 115, fig. 183

Ctenocladus

p. 118 , fig. 188

Fridaea

p. 121, fig. 194

Gomontia

p. 116, fig. 184

Gongrosira

p. 117, fig. 185

Leptosira

p. 117, fig. 187

Trentepohlia

p. 109, fig. 171

Family Cladophoraceae

Aegagropila

p. 121, fig. 193

Basicladia

p. 119, fig. 190

Cladophora

p. 120, fig. 192

Pithophora

p. 118, fig. 189

Rhizoclonium

p. 102 , fig. 158

Family Sphaeropleaceae

Sphaeroplea

p. 103 , fig. 160

4. Order Oedogoniales

Family Oedogoniaceae

Bulbochaete

p. 122, fig. 195

Oedocladium

p. 111, fig. 174

Oedogonium

p. 102, fig. 159

5. Order Ulvales

Family Schizomeridaceae Schizomeris

p. 101, fig. 157

Family Ulvaceae

Enteromorpha

p. 98 , fig. 152

Monostroma

p. 97 , fig. 151
6. Order Schizogoniales

Family Schizogoniaceae

Prasiola

p. 98 , fig. 153

Schizogonium

p. 92 , fig. 140

7. Order Chlorococcales

Family Chlorococcaceae

Acanthosphaera

p. 79 , fig. $117 \frac{1}{2}$

Chlorococcum

p. 42 , fig. 42

Desmatractum

p. 68 , fig. 97

Golenkinia

p. 61 , fig. 84

Myrmecia

p. 81 , fig. 122

Trebouxia

p. 80 , fig. 121

Family Endosphaeraceae

Chlorochytrium

p. 66 , fig. 94

Kentrosphaera

p. 84 , fig. $126 \frac{1 / 2}{2}$

Rhodochytrium

p. 66 , fig. 93

Family Botryococcaceae Botryococcus

p. 45 , fig. 49

Family Characiaceat

Actidesmium

p. 59 , fig. 80

Characium

p. 63 , fig. 87

Family Hydrodictyaceae

Euastropsis

p. 36 , fig. 33

Hydrodictyon

p. 54 , fig. 69

Pediastrum

p. 55 , fig. 70

Sorastrum

p. 60 , fig. 82

Family Coelastraceae

Coelastrum

p. 58 , fig. 77 
HOW TO KNOW THE FRESH-WATER ALGAE

Family Oocystaceae

Ankistrodesmus

p. 54 , fig. 68

Bohlinia

p. 80 , fig. 120

Cerasterias

p. 86 , fig. 130

Chlorella

p. 65 , fig. 91

Closteridium

p. 65 , fig. 90

Closteriopsis

p. 69 , fig. 98

Dactylococcus

p. 52 , fig. 65

Dictyosphaerium

p. 47 , fig. 53

Dimorphococcus

p. 47 , fig. 52

Echinosphaerella

p. 78, fig. 117

Eremosphaera

p. 81 , fig. 123

Excentrosphaera

p. 83 , fig. 126

Franceia

p. 56 , fig. 73

Gloeotaenium

p. 61 , fig. 83

Kirchneriella

p. 49 , fig. 56

Lagerheimia

p. 79 , fig. 118

Nephrocytium

p. 50 , fig. 59

Oocystis

p. 62 , fig. 85

Pachycladon

p. 85 , fig. 128

Palmellococcus

p. 82 , fig. 125

Planktosphaeria

p. 48 , fig. 55

Polyedriopsis

p. 86 , fig. 129

Quadrigula

p. 50 , fig. 60
Schroederia

p. 64 , fig. 88

Selenastrum

p. 53 , fig. 67

Tetraedron

p. 87 , fig. 131

Treubaria

p. 87 , fig. 132

Trochiscia

p. 80 , fig. 119

Westella

p. 60 , fig. 81

Family Scenedesmaceae

Actinastrum

p. 58 , fig. 78

Coronastrum

p. 42 , fig. 43

Crucigenia

p. 56 , fig. 72

Errerella

p. 57 , fig. 76

Micractinium

p. 57 , fig. 75

Pectodictyon

p. 43 , fig. 44

Scenedesmus

p. 57, fig. 74

Tetradesmus

p. 59 , fig. 79

Tetrallantos

p. 49 , fig. 57

Tetrastrum

p. 55 , fig. 71

\section{Order Siphonales}

Family Phyllosiphonaceae

Phyllosiphon

p. 66 , fig. 92

Family Dichotomosiphonaceae

Dichotomosiphon

p. 123, fig. 198

9. Order Zygnematales (Conjugales)

Family Zygnemataceae

Debarya

p. 96 , fig. 149 
HOW TO KNOW THE FRESH-WATER ALGAE

Mougeotia

p. 94 , fig. 145

Mougeotiopsis

p. 96, Fig. 148

Pleurodiscus

p. 94 , fig. 144

Sirogonium

p. 95, fig. 146

Spirogyra

p. 95 , fig. 147

Zygnema

p. 93 , fig. 142

Zygnemopsis

p. 92, fig. 141

Zygogonium

p. 93, fig. 143

Family Mesotaeniaceae

Cylindrocystis

p. 71, fig. 103

Genicularia

p. 72, Fig. 106

Gonatozygon

p. 73, fig. 107

Mesotaenium

p. 44 , fig. 46

Netrium

p. 73 , fig. 108

Roya

p. 73, fig. 109

Spirotaenia

p. 72, fig. 105

Family Desmidiaceae

Arthrodesmus

p. 76 , fig. 114

Closterium

p. 63 , fig. 86

Cosmarium

p. 76 , fig. 113

Cosmocladium

p. 46 , fig. 50

Desmidium

p. 90 , fig. 138
Docidium

p. 71, fig. 101

Euastrum

p. 75 , fig. 111

Gymnozyga

p. 90 , fig. 136

Hyalotheca

p. 90 , fig. 137

Micrasterias

p. 74 , fig. 110

Onychonema

p. 88 , fig. 133

Oocardium

p. 99, fig. 155

Penium

p. 72, fig. 104

Phymatodocis

p. 91, fig. 139

Pleurotaenium

p. 71, fig. 102

Sphaerozosma

p. 89 , fig. 134

Spondylosium

p. 89 , fig. 135

Staurastrum

p. 75 , fig. 112

Tetmemorus

p. 69 , fig. 99

Triploceras

p. 70 , fig. 100

Xanthidium

p. 77, fig. 115

B. SUB-DIVISION CHARACEAE

Chareae

Chara

Nitelleae

Nitella

p. 21 , fig. 3

Tolypella

p. 20 , fig. 1

\section{PHYLUM (DIVISION) EUGLENOPHYTA}

1. Order Euglenales Family Euglenaceae

Euglena

p. 25 , fig. 8
Lepocinclis

p. 25 , fig. 7

Phacus

p. 24, fig. 6 
HOW TO KNOW THE FRESH-WATER ALGAE

Trachelomonas

p. 24 , fig. 5
Family Colaciaceae

Colacium

p. 52 , fig. 64

\section{PHYLUM (DIVISION) PYRRHOPHYTA}

A. SUB-DIVISION CRYPTOPHYCEAE

Family Cryptochrysidaceae Chroomonas

p. 150 , fig. 254

Family Cryptomonadaceae

p. 150 , fig. 255

B. SUB-DIVISION DINOPHYCEAE

Order 1. Dinokontae

Family Gymnodiniaceae Gymnodinium

p. 151, fig. 257

Family Gonyaulacaceae

Gonyaulax

p. 152, fig. 259

Family Glenodiniaceae

Glenodinium

p. 153, fig. 261
Hemidinium

p. 153, fig. 260

Family Peridiniaceae

Peridinium

p. 152 , fig. 258

Family Ceratiaceae

Ceratium

p. 151, fig. 256

Order 2. Dinococcales

Family Dinococcaceae

Cystodinium

p. 149, fig. 253 Raciborskia

p. 149, fig. 252

Tetradinium

p. 149 , fig. 251

IV. PHYLUM (DIVISION) CHLOROMONADOPHYTA

Gonyostomum

p. 23 , fig. 4

\section{PHYLUM (DIVISION) CHRYSOPHYTA}

A. SUB-DIVISION XANTHOPHYCEAE (HETEROKONTAE)

1. Order Heterocapsales

Family Heterocapsaceae

Chlorosaccus

p. 142, fig. 238

2. Order Heterococcales

Family Pleurochloridaceae

Arachnochloris

p. 140, fig. 232

Botrydiopsis

p. 137, fig. 224

Chlorallantus

p. 141, fig. 234
Chlorocloster

p. 139, fig. 230

Diachros

p. 136, fig. 223

Goniochloris

p. 142, fig. 237

Monallantus

p. 138, fig. 227

Perone

p. 133, fig. 216

Pleurogaster

p. 139, fig. 229

Tetragoniella

p. 141, fig. 236 
HOW TO KNOW THE FRESH-WATER ALGAE

Trachychloron

p. 141, fig. 235

Family Botryochloridaceae

Chlorellidiopsis

p. 143, fig. 240

Uncertain Position

Leuvenia

p. 137, fig. 225

Family Centritractaceae

Bumilleriopsis

p. 138, fig. 228

Centritractus

p. 139, fig. 231

Pseudotetraedron

p. 137, fig. 226

Family Characiopsidaceae

Characiopsis

p. 133, fig. 217

Peroniella

p. 135, fig. 220

Family Gloeobotrydaceae

Chlorobotrys

p. 136, fig. 222

Gloeobotrys

p. 143, fig. 239

Family Chlorotheciaceae

Chlorothecium

p. 133, fig. 215

Ophiocytium

p. 134, fig. 219

Family Meringosphaeraceae

Meringosphaera

p. 140 , fig. 233

Family Mischococcaceae

Mischococcus

p. 130 , fig. 210

3. Order Heterotrichales

Family Heterotrichaceae Bumilleria

p. 132, fig. 213

Monocilia

p. 131, fig. 211

Tribonema

p. 131, fig. 212

4. Order Heterochloridales

Family Chloramoebaceae
Chlorochromonas

p. 135, fig. 221

5. Order Rhizochloridales

Family Stipitococcaceae

Stipitococcus

p. 134, fig. 218

6. Order Heterosiphonales

Family Botrydiaceae Botrydium

p. 132, fig. 214

Family Vaucheriaceae

Vaucheria

p. 124, fig. 199

B. SUB-DIVISION CHRYSOPHYCEAE

1. Order Chrysomonadales

Family Mallomonadaceae Chrysosphaerella

p. 154, fig. 262

Mallomonas

p. 147, fig. 248

Family Syncryptaceae

Derepyxis

p. 147, fig. 247

Family Synuraceae

Synura

p. 154, fig. 263

Family Ochromonadaceae

Chlorochromonas

p. 135, fig. 221

Cyclonexis

p. 155, fig. 265

Dinobryon

p. 145 , fig. 243

Hyalobryon

p. 146, fig. 244

Uroglenopsis

p. 155 , fig. 264

2. Order Rhizochrysidales

Family Rhizochrysidaceae

Chrysamoeba

p. 148 , fig. 250

Chrysidiastrum

p. 156, fig. 266

Chrysostephanosphaera

p. 157, fig. 269 
Lagynion

p. 147, fig. 246

Rhizochrysis

p. 148, fig. 249

3. Order Chrysocapsales

Family Chrysocapsaceae

Chrysocapsa

p. 157, fig. 268

Phaeosphaera

p. 156 , fig. 267

Family Hydruraceae

Hydrurus

p. 144, fig. 241

4. Order Chrysosphaerales

Family Chrysotomataceae

Chrysostrella

p. 146, fig. 245

5. Order Chrysotrichales

Family Phaeothamniaceae

Phaeothamnion

p. 144, fig. 242

C. SUB-DIVISION BACILLARIOPHYCEAE

1. Order Centrales

Family Coscinodiscaceae

Melosira

p. 186, fig. 328
Stephanodiscus

p. 186 , fig. 329

2. Order Pennales

Family Fragilariaceae Asterionella

p. 187, fig. 333

Fragilaria

p. 186 , fig. 330

Tabellaria.

p. 187, fig. 331

Family Achnanthaceae

Cocconeis

p. 188 , fig. 337

Family Gomphonemataceae

Gomphonema

p. 188, fig. 335

Family Meridionaceae

Meridion

p. 187, fig. 332

Family Naviculaceae

Navicula

p. 188 , fig. 334

Family Surirellaceae

Surirella

p. 188 , fig. 336

\section{PHYLUM (DIVISION) CYANOPHYTA}

A. SUB-DIVISION MYXOPHY-

CEAE

1. Order Chroococcales

Family Chroococcaceae

Aphanocapsa

p. 182 , fig. 320

Apanothece

p. 185 , fig. 327

Chondrocystis

p. 177, fig. 309

Chroococcus

p. 180 , fig. 316

Coelosphaerium

p. 182, fig. 319

Dactylococcopsis

p. 184, fig. 323

Glaucocystis

p. 129, fig. 208
Gloeocapsa

p. 180 , fig. 315

Gloeochaete

p. 128, fig. 206

Gloeothece

p. 185, fig. 325

Gomphosphaeria

p. 179 , fig. 314

Holopedium

p. 181, fig. 317

Marssoniella

p. 184, fig. 324

Merismopedia

p. 179, fig. 313

Microcystis

p. 181 , fig. 318

Rhabdoderma

p. 185 , fig. 326 
Synecococcus

p. 183, fig. 322

Synechocystis

p. 178, fig. 312

Tetrapedia

p. 183 , fig. 321

2. Order Chamaesiphonales

Family Chamaesiphonaceae

Chamaesiphon

p. 176, fig. 306

Family Pleurocapsaceae

Hyella

p. 176, fig. 307

Oncobyrsa

p. 177, fig. 311

Pleurocapsa

p. 177, fig. 310

Xenococcus

p. 176, fig. 308

3. Order Hormogonales

Family Oscillatoriaceae

Arthrospira

p. 159, fig. 273

Dasygloea

p. 165, fig. 284

Hydrocoleum

p. 164, fig. 282

Lyngbya

p. 159, fig. 272

Microcoleus

p. 164, fig. 283

Oscillatoria

p. 161, fig. 277

Phormidium

p. 163, fig. 281

Porphyrosiphon

p. 162, fig. 279

Schizothrix

p. 165, fig. 285

Spirulina

p. 158, fig. 270

Trichodesmium

p. 162, fig. 278
Family Nostocaceae

Anabaena

p. 158, fig. 271

Anabaenopsis

p. 171, fig. 296

Aphanizomenon

p. 172, fig. 298

Aulosira

p. 173, fig. 301

Cylindrospermum

p. 170, fig. 295

Nodularia

p. 172, fig. 299

Nostoc

p. 173, fig. 300

Wollea

p. 171, fig. 297

Family Stigonemataceae

Capsosira

p. 168, fig. 291

Hapalosiphon

p. 169, fig. 293

Nostochopsis

p. 168, fig. 290

Stigonema

p. 169, fig. 292

Family Scytonemataceae

Desmonema

p. 175, fig. 304

Diplocolon

p. 175 , fig. 305

Microchaete

p. 170, fig. 294

Plectonema

p. 161, fig. 276

Scytonema

p. 174, fig. 302

Tolypothrix

p. 174, fig. 303

Family Rivulariaceae Amphithrix

p. 160, fig. 274

Calothrix

p. 160, fig. 275

Dichothrix

p. 167, fig. 289 
HOW TO KNOW THE FRESH-WATER ALGAE

Gloeotrichia

p. 166, fig. 287

Rivularia

p. 167, fig. 288
Sacconema

p. 166, fig. 286

B. SUB-DIVISION CHLOROBACTERIACEAE

\section{PHYLUM RHODOPHYTA}

A. SUB-DIVISION PROTOFLORIDEAE

Family Goniotrichaceae Asterocystis

p. 129, fig. 207

Family Bangiaceae Bangia

p. 127, fig. 205

Family Erythrotrichaceae Compsopogon

p. 126, fig. 203

Uncertain Position

Porphyridium

p. 130, fig. 209
B. SUB-DIVISION FLORIDEAE

Family Chantransiaceae Audouinella

p. 127, fig. 204

Batrachospermum

p. 110, fig. 173

Family Lemaneaceae

Lemanea

p. 124, fig. 200

Tuomeya

p. 126, fig. 202

Family Thoreaceae

Thorea

p. 125 , fig. 201 


\section{INDEX AND PICTURED-GLOSSARY}

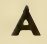

Acanthosphaera 79 Zachariasi 79

ACICULAR: needle-like in shape. Fig. 338

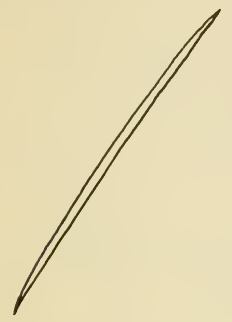

Figure 338

ACID BOG: having soft water, low or lacking in dissolved minerals; $\mathrm{pH}$ below neutral (7.0)

Acrochaetium 127

Actidesmium 59

Hookeri 59

Actinastrum 58

gracillimum 58

Hantzschii 58

Aegagropila 121

profunda 121

AERIAL: algal hobitat on moist soil, rocks, trees, etc.: involving a thin film of water; subaerial, somewhat or sometimes aerial.

AKINETE: a type of spore formed by the transformation of a vegetative cell into a thick-walled resting cell, containing a concentration of food material.

Alcohol

food reserve 9,11

preservative 16

ALKALINE WATER: containing a predominating amount of hydroxyl-ions as compared with hydrogen-ions: abundant in electrolytes; hard water lakes ordinarily are alkaline

Alligator 13

ALPINE: altitudes above tree line (usually).

AMOEBOID: like an amoebo: creeping by extensions of highly plastic protoplasm (pseudopodia).

AMORPHOUS: without definite shape; without regular form.

Amphithrix 160 janthina 160
Anabaena 158, 172, 173; also $6,160,162$ spiroides var. crassa 158 subcylindrica 158

Anabaenopsis 171 Elenkenii 171

ANASTOMOSE: to separate and come together again; a meshwork. Fig. 339

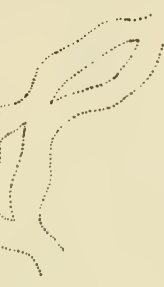

Figure 339

Angiosperms 116, 118

ANISOGAMETE: a sex cell which shows only slight differentiation in respect to maleness or femaleness.

Ankistrodesmus 54, 59, 62 , 64, 69: also 14

Braunii 54

convolutus 54

falcatus 54

fractus 54

spiralis 54

ANTAPICAL: the posterior or rear pole or region of an organism, or of a colony of cells.

ANTERIOR: the forward end: toward the top.

ANTHERIDIUM: a single cell or a series of cells in which male gametes are produced; a multicellular globular male reproductive organ in the Characeae. (See Fig. 159)

ANTHEROZOID: male se $x$ cell or gamete.

APEX: the summit; the terminus; end of a projection or of an incision.

Aphanizomenon 172; also 181

flos-aquae 172

Aphanocapsa 182

elachista 182

Grevillei 182

Aphanochaete 104, 113 polychaete 104 repens 104

Aphanothece 185 Castagnei 185

APICAL: the forward or anterior end; the top.

Apiocystis 39 Brauniana 39
APLANOSPORE: non-motile, thick-walled spore formed many within an unspecialized vegetative cell; a small resting spore.

Araceae 66

Arachnochloris 140 minor 140

ARBUSCULAR: branched or growing like a tree or bush.

ARCUATE: curved bow shaped. Fig. 340

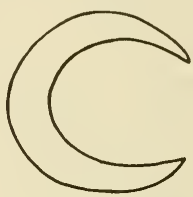

Figure 340

Ariscema 13

ARMORED: see thecate.

Arthrodesmus 76 incus 76

Arthrospira 159

Jenneri 159

Astasia 23

Asterionella 187; also 186

formosa 187

Asterococcus 46, 81

limneticus 46

superbus 46

Asterocystis 129

smaragdina 129

ATTENUATE: narrowing to a point or becoming reduced in diameter. Fig. 341

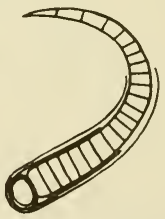

Figure 341

Audouinella 127 violacea 127

Aulosira 173 Iaxa 173

AUTOSPORES: spore-like bodies cut out of the contents of a cell which are small replicas of the parent cell and which only enlarge to become mature plants.

AXIAL: along a median line bisecting an object either transversely or longitudi- 
nally (especially the latter. e.g., an axial chloroplast). Fig. 342
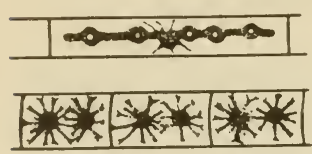

Figure 342

B

BACILLIFORM: rod-shaped.

Bangia 127 fuscopurpurea 127

Basicladia 119 Chelonum 119

BASIC WATER: hard woter containing an abundance of dissolved minerals or chemical elements.

Batrachospermum 110, 125 also 22, 127

Boryanum 110

moniliforme 110

vagum 110

BILOBED: with two lobes or extensions.

Binuclearia 105 totrana 105

BIPAPILLATE: with $t$ wo small protrusions; nipples.

BISCUIT-SHAPED: a thickened pad; pillow-shaped

BIVALVE (wall): wall of a cell which is in two sections, one usually slightly larger than the other. (See Melosira, Fig. 328)

Bladderwort: see Utricularia.

BLEPHAROPLAST: a granular body in a swimming organism from which a flagellum (organ of tocomotion) arises.

BLOOM: see Water Bloom.

Blue-green Algae 6

Bohlinia 80,84 echidna 80

Botrydiopsis 137, 143 arhiza 137 eriensis 137

Botrydium 132; also 22 granulatum 132 Wollrothii 132

Botryococcus 45, 129; also 22

Brounii 45

BRISTLE: a stiff hair: needle-like spine.

Brown Algae, see Phaesphyto

Bulbochaete 122; also 102 congener 122 insignis 122

Bumilleria 132 exilis 132 sicula 132

Bumilleriopsis 138 brevis 138

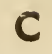

Calothrix 160, 167

atricha 160

Braunii 160

epiphytica 160

CAPITATE: with an enlargement or a head at one end. Fig. 343

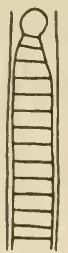

Figure 343

Capsosira 168 Brebissonii 168

CAROTENE: orange - yellow plant pigment of which there are four kinds in algae; a hydrocarbon, $\mathrm{C}^{\mathrm{H}} \mathrm{H}$

CARPOGONIUM: female sex organ in the red algae a flask-shaped cell with a long, hair-like extension, the trichogyne.

Carteria 31

cordiformis 31

Klebsii $3 i$

CARTILAGINOUS: tough but pliable; resilient.

CELLULOSE: a $n$ insoluble carbohydrate, $\mathrm{C}_{6} \mathrm{H}_{10} \mathrm{O}_{5}$, of which most plant cells are composed.

CENTRAL BODY: the central region of a blue-green algal cell, relatively unpig. mented and containing nuclear granules.

CENTRALES: a subclass of the Diatomaceae which includes cells with radial symmetry and radiately disposed wall markings: cells round in end view, 186.

Centritractus 139 belanophorus 139

Cephaleuros 115; also 13, 22 virescens 115

Cerasterias 86 irregulare 86

Ceratium 151 nirundinella 151

Ceratophyllum 166

Chaetonema 113 irregulare 113

Chaetopeltis 114 orbicularis 114

Chaetophora 122; also 113, 123

elegans 122

incrossata 122

Chaetosphaeridium 51, 67 99

globosum 51
Chamaesiphon 176

incrustans 176

Chamoesiphonaceae 177

Chantransia 127

Chara 21; also 20

conescens 21

coronata 21

excelsa 21

Characeae 1, 6, 20

Characiopsis 133,135 ; also $63,68,134$

acuta 133

cylindrico 133

spinifer 133

Characium 63,68 ; also 133 134

Debaryanum 63

ornithocephalum 63

rostratum 63

Charophyceae, 4

Chlamydobotrys 27 gracilis 27

Chlamydomonas 34,129 ; also 82

nivalis 34 ; also 13

Palmella-stage 40

polypyrenoideum 34 sphagnicola 34

Chlorallantus 141 oblongus 141

Chlorangium 52 stentorinum 52

Chlorella 65, 83 conductrix 65 ellipsoidea 65 parasitica 65

Chlorellidiopsis 143 separalibis 143

Chlorobotrys 136, 143 regularis 136

Chlorochromonas 135 minuta 135

Chlorochytrium 66 ; also 37 , 84

Lemnae 66; also 37

Chlorocloster 139 pyreniger 139

Chlorococcales 6, 64, 65 $80,82,84$

Chlorococcum 42, 62, 83

humicola 42

infusiorum 42

Chlorogonium 33

Chloromonadophyta 8, 10, 23

Chloromonads 8

Chlorophyceae 4

CHLOROPHYLL: a green pigment of which there are five kinds in the algae, Chlorophyll-a occuring in all of the algal Divisions.

Chlorophyta $4,6,7,22,25$, $124,128,131,136,139$

CHLOROPLAST: a body of various shapes within the cell containing the pigments of which chlorophyll is the dominant one.

Chlorosaccus 142 fluidus 142

Chlorosarcina 37 consociato 37

Chlorothecium 133, 135 Pirottae 133

Chlorotylium 117 cataractum 117

Chodatella 79, 84 
Chondrocystis 177 Schauinslandii 177

CHROMATOPHORE: bंody within a cell containing the pigments of which some one other than chlorophyll (green) is predominant; may be red, yellow, yellow-green or brown.

Chroococcaceae 178

Chroococcus 180 limneticus 180

limneticus var. 180

Prescottii 180

turgidus 180

Chroomonas 150

Nordstedtii 150

Chrysamoeba 148, 156 radians 148

Chrysidiastrum 156 catenatum 156

Chrysocapsa 157 paludosa 157 planctonica 157

Chrysophyceae 144

Chrysophyto 7, 11, 22, 63, $68,124,128,131,132$, $134,135,139,144,148$

Chrysosphoerella 154 longispina 154

Chrysostephanosphaera 157 globulifera 157

Chrysostrella 146 paradoxa 146

CILIA: fine, hair-like extensions of a cell membrane used as organs of locomotion or for feeding in the Protozoan Class, Ciliata.

CILIATA: a Class of the Protozoa, swimming by means of numerous, fine, hair-like extensions of the cell membrane.

Citrus, trees as hosts for algae, 115

Cladophora 120, 121; also 102

Cladophora Balls 120

Cladophoraceae 67

Class, defined 4

Closteridium 65 lunula 65

Closteriopsis 69 longissima 69

Closterium 63, 68, 70, 72 . also 65,69

Coccomyxa 40, 44 dispar 40

Coccomyxaceae 78

Cocconeis 188

Pediculus 188

Coelastrum 58 cambricum 58 microporum 58

Coelosphaerium 182, 185; also 67

Kuetzingianum 182

Naegelianum 182

COENOCYTIC: a plant with multinucleate cells or celllike units; a multinucleate non-cellular plant, e.g. Vaucheria (See Fig. 199).

Coenogonium 109

Colacium 52, 100 arbuscula 52
Coleochaetaceae 51

Coleochaete 97, 112, 114, 122

Nitellarum 97

orbicularis 97

soluta 97

COLLAR: a thickened ring or neck surrounding the opening into a shell through which a flagellum projects from the inclosed organism.

Collecting $12,14,15$
COLONIAL MUCILAGE: a gelatinous investment or sheath which incloses several to many cells.

COLONY: a group or closely associated cluster of cells, adjoined together or merely inclosed by a common investing mucilage or sheath; cells not arranged in a linear series to form a filament.

COLUMNAR CELLS: S e e corticating cells.

Compsopogon 126

coeruleus 126

CONCENTRIC: a r r anged about a common center.

CONE-SHAPED: CONICAL: a figure circular in cross section, broad at the base and tapering symmetrically from base to apex.

CONFLUENT: running together or intermingling, as mucilaginous sheaths of plants becoming intermingled. Fig. 344

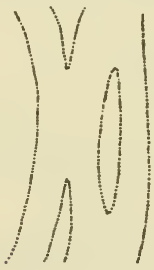

Figure 344

CONJUGATION: sexual reproduction between cells which become joined or "yoked" together, the gametes (sex cells) moving in an amoeboid fashion. Fig. 345

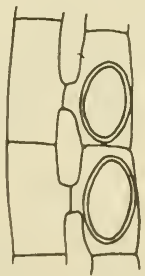

Figure 345
CONJUGATION TUBES: tubes which are put out by one or both cells in sexual reproduction providing for the uniting of gametes; see Conjugation.

CONSTRICTED: cut in or incised, usually from two opposite points on a cell so that an isthmus is formed between two parts; indented, as are the lateral walls of cells of a filament at the cross walls. Fig. 346

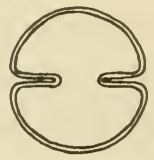

Figure 346

CONTRACTILE VACUOLE: a small vacuole (cavity) which is bounded by a membrane that pulsates, expanding and contracting.

Copepod 2

Coronastrum 42, 51 aestivale 42

CORTEX; CORTICATING CELLS: cells superimposed on the main filament or axial part of o plant body; investing cells, e. g., Chara, Batrachospermum. (See Fig. 2)

Cosmarium 76; also 6, 75, $88,89,99$ margaritatum 76 panamiense 76

Cosmocladium 46 tuberculatum 46.

CRENULATE: wavy with small scallops; with small crenations.

CRESCENT: an arc of a circle; a curved figure tapering to horn-like points from a wider, cylindrical midregion. See lunate.

CROWN CELLS: the cells formed at the tips of the investing elements that are spirally twisted about the egg in the Characeoe.

Crucigenia 56 ; also 49 irregularis 49 rectangularis 56 tetrapedia 56

Cryptomonas 150 erosa 150

Cryptophyceae 5, 7

Cryptophyta 8,11

Ctenocladus 118 circinnatus 118

CUP-SHAPED: a more or less complete plate (as a chloroplast) which lies just 
within the cell wall, open at one side
cup. Fig. 347

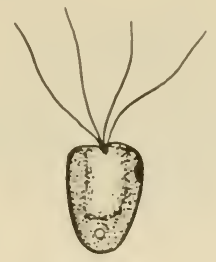

Figure 347

CUSHION: a pad; a thickened plate.

Cyanoderma bradypodis 13

Cyanophyto 7, 12, 139, 158, 183

Cyclonexis 155

annulatus 155

Cyclops 52

CYLINDRICAL: a figure, round in cross section, elongate with parallel lateral margins when seen from the side, the ends square or truncate. See subcylindrical.

Cylindrocapsa 108 geminella var. minar 108

Cylindrocystis 71; also 72 Brebissonii 71

Cylindrospermum 170 majus 170 marchicum 170

CYST, a thick-walled resting cell or stage of an organism.

Cystodinium 149 carnifax 149

\section{D}

Dactylococcopsis 184 acicularis 184 fascicularis 184

Dactylacoccus 52, 58 infusionum 52

Dactylothece 44 ; also 78 confluens 44

Dasygloeo 165 amorpho 165

DAUGHTER CELLS: cells produced directly from the division of a primary or parent cell; cells produced from the same mother cell.

DAUGHTER COLONY: O group of cells closely arranged, having bee $n$ formed from the division of a parent cell.

Debarya 96

Derepyxis 147 dispar 147

Dermatophyton, synonym of Ulvella, 115

Desmatractum 68, 77 bipyramidatum 68
Desmidium 90; also 89

Baileyi 90; also 89
Grevillii 90

Desmids, 15, 46, 63, $72,78,89-91$

Desmonema 175

Wrangelii 175

Diachros 136, 143

simplex 136

Diatoms 7, $11,12,145,186$
Dichothrix 167

gypsophila 167

Dichotomosiphon 123

tuberosus 123

DICHOTOMOUS: dividing or branched by $r$ e pe a ted forkings, usually into two equal parts, or segments.

Dicranochaete 51, 67 reniformis 51

Dictyosphaerium 47; also 60 oulchellum 47

Dimorphococcus 47,60 cordatus 47

lunatus 47

Dinabryan 145, 146, 155 , 156; also 2,22 sertularia 145

Dinaflagellatae 2, 8, 11, 14, 82,149

Diplacolon 175 Heppii 175

DISC; DISC-SHAPED: a flat (usually circular) figure; a circular plate.

Dispora 49 crucigeniaides 49

DISTAL: the forward or anterior end or region as opposed to the basal end

Division (of the plant kingdom) defined, 4

Dacidium 71

Baculum 71 undulatum 71

DORSAL: the back or upper surface or part as opposed to the under or lower (ventral) surface of a cell or organism.

DORSIVENTRAL: referring to differentiation into an upper (dorsal) and a lower (ventral) surface or side.

Draparnaldia 123 glomerata 123

Draparnaldiopsis 123

Drying Specimens, 16

Dunaliella 36 salina 36

viridis 36

DWARF MALE: a minute male plant (as in the Oedogoniaceae) growing on or near the female sex organ (oogonium) in - larger filament.

\section{E}

ECCENTRIC: arranged without a common center; located to one side of center
Echinosphaerella 78; also 79 limretica 78

Economic Importance 1, 2

Elakatothrix 39, 42, 50; also 78

americana 39

gelatinasa 39

viridis 39

ELLIPSOID: an ellipse, a plane figure with curved margins which is elongate, the poles more sharply rounded than the lateral margin. Fig. 348

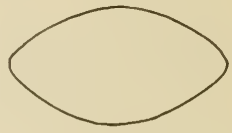

Figure 348

ENCYSTED: See cyst.

ENDOPHYTE: living within the cells or internally among the cells of a plant.

ENDOSPORES: non - motile spores, indefinite in number, cut out from within a plant cell, or (as in Chamaesiphon) cut off from the tip of the pritoplast and liberated one by one.

ENDOZOIC: living within the cells or among the tissues of an animal.

Enteramorpha 98 intestinalis 98

Entocladia 112, 114 polymarpha 112

EPIPHYTE: living upon a plant, sometimes living internally also.

EPIZOIC: living on or attached to an animal.

Eremosphaera 81 viridis 81

Errerella 57

bornhemiensis 57

Euastropsis 36; also 55 Richteri 36

Euastrum 75, 77; also 6 pectinatum var. inevolutum 75 oinnatum 75

Eudorina 29 ; also 26 elegans 29 unicocca 29

Euglena 25, 130; also 10, 23,52

convoluta 25

elastica 25

Euglenaceae 2

Euglenophyta 7, 10, 23

EUPLANKTON: true or openwater plankton (floating) organisms. See plankton.

Excentrosphaera 83 viridis 83

EYE-SPOT: a granular or complex of granules (red or brown) sensitive to light and related to response to light by swimming organisms. 


\section{HOW TO KNOW THE FRESH-WATER ALGAE}

\section{$\mathbf{F}$}

FAA (Preservative) 16

FALSE BRANCH: a branch formed by lateral growth of one or both ends of a broken filament; a branch not formed by lateral division of cells in an unbroken filament.

FALSE FILAMENT: an orrangement of cells to form a short or loose thread; not forming a definite linear series of cells.

Fomily (definied), 3

FIBRIL: a fine thread.

FILAMENT: a thread of cells; one or more rows of cells; in the bluegreen algae the thread of cells together with a sheath that may or may not be present, the thread of cells referred to as o trichome, which see.

FISSION: cell division by constriction not involving nucleor division (mitosis).

FLAGELLAR VACUOLES: cavities in the cytoplasm at the anterior end of a motile cell, at the base of the flagella, which see.

FLAGELLUM: a relatively coarse, whip-like orgon of locomotion, arising from a special granule, the blepharoplast, within a cell.

FLANGE: a longitudinal bulge or wing-like vertical extension from the surface of an organism or cell.

FLASK-LIKE: broad ot the base and abruptly narrowed to a neck-like extension.

FLORIDEAN STARCH: a food reserve produced within the red algae (Rhodophyta) different from the starches formed by other plants.

FOLIOSE: leaf-like; a flat or curled, expanded thallus.

Formalin (preservative), 16

Fragilaria 187; also 186

Franceia 56, 79, 84 Droescheri 56

Fridaea 121 torrenticola 121

FUCOXANTHIN: a brown pigment predominant in the Phaeophyta.

FUSIFORM: a figure broadest in the midregion and gradually tapering to both poles which may be acute or bluntly rounded shaped like a spindle. Fig. 349

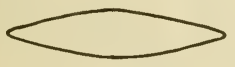

Figure 349

\section{G}

GAMETANGIUM: any cell, specialized or unspecialized, which produces gametes (male or fermale sex cells).

GAMETE: a sex cell; cells which unite to produce a fertilized egg or zygospore, which see.

Geminella 106, 107

interrupta 106

mutabilis 106

Genicularia 72, 94; also 73 elegans 72

GENICULATE; GENICULATION: bent, as a kneejoint; bending or abruptly curved.

Genus, defined, 3

GIRDLE VIEW: see Valve.

Glaucocystis 129, 178

duplex 129

Nostochinearum 129

Glenodinium 153

Kulczynski 153

Gloeobotrys 143

limneticus 143

Gloeocapsa 180 punctata 180

Gloeochaete 128, 178; also 129

Wittrockiana 128

Gloeochloris 142 Smithiana, synonym of Chlorosaccus fluidus, 142 Gloeocystis 41, 46, 48, 82, 129; also 40, 99

ampla 41

gigas 41

major 41

Gloeotaenium 61, 85 Loitelsbergerianum 61

Gloeothece 185

linearis 185

Gloeotrichia 166; also 167

echinulata 166

natans 166

Pisum 166

Glycerin, in preservative, 16 17 ; in mounts, 22, 150

Glycerin Jelly, for mounts, 16,17

GLYCOGEN: a starch-like storage product questionably identified in food granules of the Cyanophyta.

Golenkinia 61, 79 paucispina 61 radiata 61

Gomontia 116; also 117 Holdenii 116

Gomphonema 188

Gomphosphaeria 179, 184 aponina 179 lacustris 179

Gonatozygon 73 aculeatum 73

Gonatozygonoceae 72, 73

Gongrosira 117, 119; also 118

Debaryana 117

Goniochloris 142 sculpta 142

Gonium 26 pectorale 26
Gonyaulax 152

palustre 152

Gonyostomum 23; also 8 semen 23

GREGARIOUS: an association: groupings of individuals not necessarily joined together but closely assembled.

GULLET: a canal leoding from the opening of flagellated cells into the reservoir in the anterior end. (See Euglena, Fig 8.)

Gymnodinium 151

fuscum 151 palustre 151

Gymnozyga 90; also 88 moniliformis 90

GYPSUM: granules of calcium sulphate which occur in the vacuoles of some desmids. (See Closterium, fig. 86.)

\section{H}

HAEMATOCHROME: a red or orange pigment, especially in some Chlorophyto and Euglenophyta, which masks the green chlorophyll.

Haematococcus 30,130 ; also 22,33

lacustris 30

Hapalosiphon 169

hibernicus 169

HARD WATER: abundantly supplied with dissolved minerals: with o $\mathrm{pH}$ above neutral (7.0).

Hemidinium 153

nasutum 153

Herborium Specimens i6

HETEROCYST: on enlarged cell in some of the filamentous blue-green algoe, usually empty and different iln shope from the vegetative cells. Fig. 350

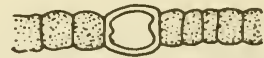

Figure 350

HETEROGAMETE: a gamete (sex cell) clearly differentiated in respect to moleness or femaleness (antherozoid and egg).

Heterokontae 126

HOLD-FAST CELL: a basal cell of a filament or thallus differentiated to form on attaching organ.

Holopedium 181 irregulare 181

HORIZONTAL GROWTH: growth more or less at right angles to outwardly or upwardly projecting filaments or parts; usually growth parallel with a substrate to which a plant is attached. 
Hormidiopsis 105 ellipsoideum 105

Hormidium 107; also 104106

Klebsii 107

Hormotila 99

mucigena 99

Hot Springs 13

H-SHAPED SECTIONS: segments of filaments or terminal cells of filaments which result from separation of cells, one from the other, ot the midregion rather than of the cross walls, the cell wall being composed of two sections which adjoin and overlap midway between the end walls. (See Figs. $172,212)$; also in a chloroplost shape where there are 2 brood sections lying along the side walls and connected by a narrow cross band. Fig. 35

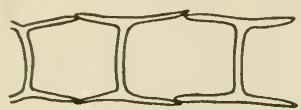

Figure 351

Hyalobryon 146

mucicola 146

Hyalotheca 90; also 88, 135 dissiliens 90 mucoso 90

Hydra 65

Hydrocoleum 164 homeotrichum 164 oligotrichum 164

Hydrodictyon 54 reticulatum 54

Hydrurus 144

foetidus 144

Hyella 176

fontana 176

\section{I}

INCISED; MEDIAN INCISION: cut in; with a narrow cut from the margin. Fig. 352

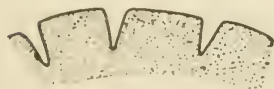

Figure 352

Indian Turnip 66

INFOLDED: as in cross walls of a filamentous algo which are not smooth, even membranes but have folds extending bock into the cavity of the cell. Desmidium and certain species of Spirogyra have this type of wall; replicate.

INTERCALARY: arranged in the some series, as spores or heterocysts which occur in series with vegetotive cells rother than being terminal or lateral.

INTERNODE: the spoce or section of a filament or thallus extending between branch-bearing or enlarged portions (nodes).

INTERSTICES: openings or spaces between adjoined cells; openings in the muciloge which incloses colonial algoe.

INTESTINIFORM: a thallus in the form of a tube, often crinkled, sometimes branched.

INVAGINATION: concavity; a depression from an otherwise smooth or plone surface.

IODINE TEST: application of a weak solution of iodine (Lugol's) to determine presence of starch; starchiodide, which is formed when iodine is opplied to cells of the Chlorophyto, appears os a blue-black substance.

ISODIAMETRICAL: a figure with oll plones hoving an equal diameter or nearly so.

ISOGAMETE: a sex cell which shows no detectable differentiation in respect to maleness or femaleness.

\section{J}

JOINT: point or plane where two cells or elements adjoin.

Jack-in-the-pulpit, see Arisaema

\section{1}

KELP: common name for the larger brown sea weeds.

Kentrosphaera 84

Bristolae 84

Kirchneriella 49, 65; also 53 lunaris 49

obesa var. major 49

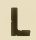

Lagerheimia 79, 84; also 56 longiseta 79 quadriseta 79

Lagynion 147 reductum 147

triangularis var. pyramida tum 147

LAMELLA; LAMELLATE: with layers; with plotes lying against one another.
LAMINARIN: a polysaccharide carbohydrate used as food storage in Phaeophyto.

LAMINATE: plate-like; layered.

LATERAL CONJUGATION: reproduction involving the formation of a connecting tube oround the end wall of two adjocent cells in the same filament so that contents of the cell may fuse to form a zygospore.

Lemanea 124 annulata 124

Lemna 12, 37, 66 trisulca 12, 66

Lepocinclis 25 acuta 25 glabra fa. minor 25

Leptosira 117 . also 22 Mediciana 117

LEUCOSIN: a whitish food reserve characteristic of many of the Chrysophyto especially the Heterokontae; gives a metallic lustre to cell contents.

Leuvenia 137 natans 137

LICHEN: a duplex plant thallus formed by a fungus and an alga living in close association 80 109

Lime (Marl Deposits) 21

LINEAR SERIES: cells or units arronged in a single row.

Lobomonas 33 rostrata 33

LOBULE: a small lobe; a secondary division of a lobe.

LONGITUDINAL FURROW: groove in the dinoflagellate cell which extends parallel with the long axis.

LORICA: a shell-like structure of varying shapes which houses an organism has an opening through which organs of locomotion are extended. (See Trachelomonas, Fig. 5.) Fig. 353

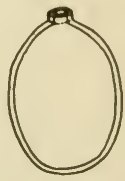

Figure 353

LUNATE: crescent - shaped, as of the new moon.

Lyngbya 159, 162

Birgei 159

contorta 159 


\section{M}

Macrocystis 2

Magnolia 115

Malleochloris 67; also 100 sessilis 67

Mallomonas 147

acaroides 147

caudata 147

pseudocoronata 147

Mangrove 126

Mannitol 9

Mare's Eggs 173

Marssoniella 184

elegans 184

MEDIAN INCISION: See incision.

Melosiro 186; also 187

granulata 186

Meridion 187

circulare 187

Meringosphaera 140 spinosa 140

Merismopedia 179; also 181

convoluta 179

elegans var. major 179 glauca 179

Mesotaeniaceae 73

Mesotaenium 44, 74

Greyii $\mathbf{4 4}$

macrococcum 44

METABOLIC: plastic, changing shape in motion as in many Euglena.

METABOLISM: referring to the physiological octivities within a living cell.

Micractinium 57

pusillum 57

quadrisetum 57

Micrasterias 74, 89; also 6 americana var. Boldtii 74 foliacea 74 radiata 74

Microchaete 170, 174; also 173

diplosiphon 170

robusta 170

Microcoleus 164

lacustris 164

vaginatus 164

MICROCRUSTACEAN: copepods, water fleos, Cladocera, etc., microscopic members of the Class Crustaceo.

Microcystis 181, 182

geruginosa 181

flos-aquae 181

MICROFAUNA: microscopic onimals; see Microcrustaceo.

MICRON: a unit of microscopical measurement; one $1 / 1000$ of a millimeter, determined by using a micrometer in the eyepiece of the microscope which has been calibrated with a standard stage $\mathrm{mi}-$ crometer. Expressed by the symbol,

Microspora 10́9; also 103, 131
floccosa 109
Loefgrenii 109
Willeana 109

Microthamnion 120

Kuetzingianum 120

strictissimum 120

Mischococcus 130,142

confervicola 130

Monallantus 138

brevicylindrus 138

MONAXIAL: with one axis: with a single row of primary cells in a thallus.

MONILIFORM: orranged like a string if beads; beadlike. Fig. 354

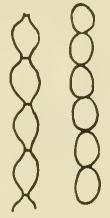

Figure 354

Monocilia 131

flavescens 131

viridis 131

Monostroma 97: also 98 latissimum 97

MOTHER CELL: the cell which by mitosis or by internal division gives rise to other cells (usually spores).

Mougeotia 94, 96, 116; also 3

elegantula 94

genuflexa 94

Mougeotiopsis 96

calospora 96

Mounting 6

MULTIAXIAL: with more than one axis or more than one longitudinal strand in a thallus.

MULTINUCLEATE: with many nuclei; see Coenocytic.

MULTISERIATE: cells arranged in more than one row; a filament two or more cells in diameter.

Myrmecia 81

aquatica 81

Myxophyceae 22

\section{$N$}

Nannochloris 78, 85

bacillaris 78

Novicula 188; also' 187

Nephrocytium 50, 61

Agardhianum 50

ecdysiscepanum 50

limneticum 50

lunatum 50

obesum 50

Netrium 73

digitus 73

Nitella 21; also 12, 20,97 flexilis 21

tenuissima 21

NODE: a position on a filament or thallus from which branches or lateral organs develop, usually enlarged or swollen: o joint in o thallus.

NODOSE, with regular swellings or nodes about a longitudinal axis.

Nodularia 172

spumigena 172

NODULE, a small swelling: a tubercle or button-like knob.

Nostoc 173; also 158, 185 amplissimum 173

commune 173

linckia 173

pruniforme 173

Nostochopsis 168

lobatus 168

\section{0}

OBLATE, slightly flattened sphere almost globular. Fig. 355

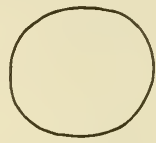

Figure 355

OBLONG, a curved figure, elongate with the ends broodly rounded but more sharply curved than the lateral margins. Fig. 356

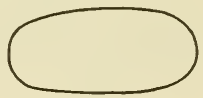

Figure 356

OBOVATE, an ovate figure, brooder at the onterior end than at the posterior. Fig. 357

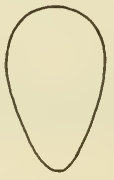

Figure 357

Oedocladium 111; also 102

Hazenii 111

Oedogoniaceae 102

Oedogonium 102: also 103 122

crispum 102

Westii 102 


\section{HOW TO KNOW THE FRESH-WATER ALGAE}

OBLATE-SPHEROID, a figure which is a flattened sphere; an almost globular figure flattened on one side. (See Fig. 355)

Ochromonas, Synonym for Chlorochromonas, 135

Oncobyrsa 177 rivularis 177

Onychonema 88 filiforme 88 laeve vor. latum 88

Oocardium 99 stratum 99

Oocystaceae 129

Docystis 62, 85; also 6,36 , 37

\section{Borgei 62}

Eremosphaeria 62

OOGONIUM, a female sex organ, usually an enlarged cell; an egg case.

OOSPORE, a thick-walled resting spore formed from a fertilized egg.

OPAQUE, not permitting the transmission of light.

Ophiocytium 134, 138, 140, 142; also 139

cochleare 134

desertum var, minor 134 gracilipes 134 parvulum 134

Ophrydium 65

Order, defined 3

Oscillatoria 161: also 157. $158,159,163$ rubescens 161 splendida 161

Oscillatoriaceae 158

Durococcus 64,69 bicaudatus 64

OVAL, an elongate, curved figure with convex margins and with ends broadly and symmetrically curved but more sharply so than the lateral margins. Fig. 358

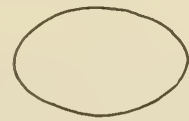

Figure 358

OVOID, shaped like an egg; a curved figure broader at one end than at the other Fig. 359

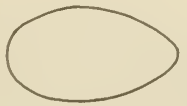

Figure 359

\section{Pachycladon 85 umbrinus 85}

Palmella 38,41 ; also 40 miniata 38 mucoso 38

Palmellaceae 99

Palmella Stage of Chlamydomonas 40

Palmellococcus 82,85 miniatus 82

Palmodictyon 43, 100, 110 varium 43 viride 43

Pandorina 28; also 26 morum 28

PARAMYLUM, a solid starch-like storage product in the Euglenophyta.

Paranema 23

PARASITIC, living on or in another organism at the expense of the host; often pathogenic.

PARIETAL, along the wall; arranged at the circumference; marginal as opposed to central or axial in location. Fig. 360

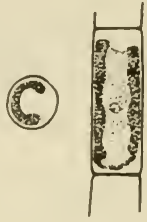

Figure 360

Pascheriella 27; also 29 tetras 27

PEAR-SHAPED, a figure which is elongate and ovate, wider at one end than of the other, usually distinctly narrowed in the midregion.

PECTIN: a gelatinous carbohydrate deposited in the cell or in the cell wall of many algae.

Pectodictyon 43 cubicum 43

PECTOSE, See Pectin

Pediastrum 55,56 ; also 36 biradiatum var. emarginatum 55

Boryanum 55

obtusum 55

simplex 55 tetras 55

PEDICEL: a small, basal stalk.

PELLICLE, the outer membranous covering as in the Euglenophyta: a skin.

Penium 72 margaritaceum 72

PENNALES, a subclass of the Diatomaceae in which the cells are bilaterally sym- metrical and in which wall decorations are bilateral in arrangement from a longitudinal axis, 186

PERFORATE, with openings; with pores.

PERIDININ, a brown pigment characteristic of the Dinoflagellatae.

Peridinium 152; also 153 wisconsinense 152

PERIPHERY, the outer boundary; the surrounding outer part.

PERIPLAST, see Pellicle.

Perone 133 dimorpha 133

Peroniella 135,142 Hyalothecae 135

Phacotus 32; also 33 lenticularis 32

Phacus 24: also 25 curvicauda 24 triqueter 24

Phoeophyta 2, 9, 11

Phaeosphaera 156 perforata 156

Phaeothamnion 144 confervicola 144

Phormidium 163, 164 ambiguum 163 favosum 163 inundatum 163

PHOTOSYNTHESIS, physiological process by which plants with chlorophyll manufacture carbohydrates in the presence of light.

PHYCOCYANIN, a blue pigment found in the Cyanophyta and the Rhodophyta.

PHYCOERYTHRIN, a red pigment found in the Rhodophyta and in some $\mathrm{Cy}$ anophyta.

PHYCOPYRRIN, a red or reddish-brown, water-soluble pigment in the chromatophores of the Dinoflagellatae.

Phyllosiphon, 66, 123; also 13

Arisarii 66

Phylum, defined, 2

Phymatodocis 91

Nordstedtiana 91

PIGMENTATION; PIGMENTS, colored substances, either localized in special bodies (plastids) within the cell, or in solution within the cytoplasm.

PIGMENT - SPOT, see Eyespot

Pithophora 118,121

Mooreana 118 Oedogonia 118

PLACODERM DESMIDS, referring to those desmids which have the cell wall composed of two sections that are adjoined in the midregion of the cell where there often is a constriction so that "semicells" are formed. 
$P L A N E$ (END WALLS), smooth, not folded walls; 361

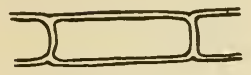

Figure 361 ing in the water, or if swimming, not able to move against currents.

Plankton Net 14

Planktosphaeria 48, 62 gelatinosa 48

PLASTID, a body or organelle of the celle, either containing pigments or in some cases colorless.

PLATE, sections, polygonal in shape, composing the zell wall of some Dinoflagellate (the thecate or ormored dinoflogellates). Fig. 362

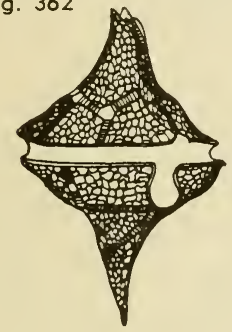

Figure 362

Platydorina 26 caudatum 26

Platymonas 31 elliptica 31

Plectonema 161 Wollei 161

Pleodorina 30 , also 29

californica 30 illinoisensis 30

Pleurocapsa 177 minor 177

Pleurococcus 53,62, 83 vulgaris 53

Pleurodiscus 94 purpureus 94

Pleurogaster 139, 140 lunaris 139

Pleurotoenium 71: olso 72 nodosum 71 trabecula 7

POLAR; POLE, referring to the two opposite ends of a cell or an orgonism. or to differentiate points in a circular cell; the ends of an axis.

Polyblepharides 35 fragariiformis 35

Polyedriopsis 86,87 quadrispina 86 spinulosa 86
POLYGONAL, many sided. OLYHEDRAL, a figure with more thon four sides.

Porphyridium 130 cruentum 130

Porphyrosiphon 162 Notarisii 162

POSTERIOR, toward the rear; the end opposite the forward or anterior end of cell or of on organism.

Prasinocladus 100 lubricus 100

Prasiola, 98; also 92 crispa 98

Preserving; Preserving Fluids 16,17

PROCESS, an extension of a cell, or of a cell wall, or of a thallus; a horn, arm, or abrupt protrusion from a plane surface. Fig. 363

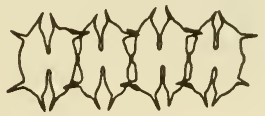

Figure 363

Protococcus 53, 62, 83; also 104

viridis 53

Protodermia 114 viride 114

PROTONEMA, the filamentous stoge in the development of moss plants.

PROTOPLAST, the living part of a cell: the cell membrane and its contents, usually inclosed by a cell wall of dead material.

Protozoo 2, 12, 23

PSAMMON, the organisms inhobiting the soil (especially sand) above the high water level of lake or river beaches.

Pseudochoete 112 gracilis 112

PSEUDOCILIA, meaning false cilia: flagella-like structures not used for locomotion.

PSEUDOP A REN CHYMATOUS, a false cushion; a pillow-like mound of cells (usually attoched) which octually is a compoct of short often branshed filaments. Fig. 364

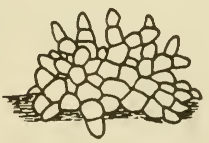

Figure 364
PSEUDOPODIUM, meaning a false foot; locomotory organ formed by lobe-like extension of the protoplasm, found in some Chrysophyto and in the Sarcodina Protozoa.

Pseudotetraedron 137 neglectum 137

Pseudoulvella 115 americana 115

PSEUDOVACUOLE, meaning o false vacuole; a pocket in the cytoplasm of many blue-green algae which contains gas or mucilage, is light-refractive. (See Microcystis, Fig. 318.)

Pteromonas .33 aculeata 33

PUNCTAE, minute, pin-point pores within the cell wall; minute pits either extending completely through the wall or not. Fig. 365

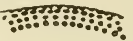

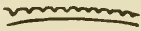

Figure 365

PYRAMIDAL; PYRAMIDATE, in the shape of a pyramid; a pointed, 3-sided figure with a broad base. Fig. 366

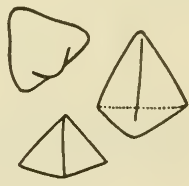

Figure 366

Pyramimonas 35; also 10 tetrarhynchus 35

PYRENOID, a protein body around which starch or paramylum collects in a cell, usually buried in o chloroplast but sometimes free within the cytoplasm. PYRIFORM, see Pear-shaped Fig. 367

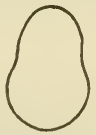

Figure 367

Pyrrhophyta $8,11,82$ 


\section{$Q$}

QUADRATE, four-sided; with a general outline showing four sides.

Quadrigulo 50 Chodatii 50

\section{$\mathbf{R}$}

Raciborskia 149 bicornis 149

RADIATE, extending outward in several planes from o common center: extending in one plane in several directions from a common point.

Radiofilum 106 conjunctivum 106 flavescens 106

Rogweed 66

RAPHE, a longitudinal canal within the wall of diatoms belonging to the Pennales, forming a median line on one or both sides of the diotom shell.

RECTANGULAR, a figure with four right angles.

RECTILINEAR, arranged in straight rows in two directions.

Red Algae, see Rhodophyta

Red Snow, see Snow

RENIFORM， kidney - shoped; bean-shaped. Fig. 368

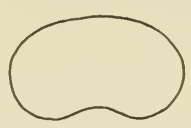

Figure 368

REPLICATE, infolded; folded back as in the cross walls of some Spirogyro; not a straight or plane cross wall. Fig. 369

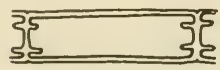

Figure 369

RESERVOIR, covity in the anterior end of flagellated cells from which the organs of locomotion arise.

RETICULATE, netted; orranged to form a network; with openings. Fig. 370

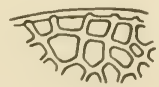

Figure 370
Rhabdoderma 185 lineore 185

Rhizochrysis 148, 156 limnetica 148

Rhizoclonium 102, 116, 121 . also 103

hieroglyphicum 102

Hookeri 102

RHIZOID; RHIZOIDAL, rootlike; o downward projecting root-like branch or cell, usually without regularity.

RHIZOPODIAL, irregularly branched, root-like extensions of protoplasm used for locomotion.

Rhodochytrium 66; also 22 spilanthidis 66

Rhododendron 115

Rhodophyta $8,11,22,110$ $124,126,127,129$

Ricciocarpus 12 natons 12

Rivulario 167; also 166

Rivulariaceoe 160

Rotifer 12

Roya 73

obtusa 73

\section{S}

SACCATE, like a sac; bolloon-like cell or colony of cells, or plant body. Fig. 371

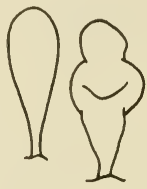

Figure 371

SACCODERM DESMID, folse desmids; cells which hove plane, unpitted walls all in one piece. See Placoderm Desmid.

Sacconema 166 rupestre 166

SARCINA ARRANGEMENT cells orranged in the form of a cube.

SCALARIFORM, lodder-like: sexual reproduction by conjugations tubes formed between cells of two filaments forming a ladderlike figure.

Scenedesmus 57, 58; also 6,36

bijuga var. alternans 57

incrossotulus var. mononae 57

opoliensis 57

quadricauda 57

Schizochlamys 45 ; also 136 gelatinosa 45

Schizogoniaceoe; Schizogonioles, 92, 98
Schizogonium 92; also 98 crenulatum 92

murale 92

Schizomeris 101, 110 Leibleinii 101

Schizothrix 165 tinctoria 165

Schroederia 64, 69 ancora 64

Judayi 64

setigera 64

Scotiella 84 ; also 14,33 nivalis 84

SCROBICULATE; SCROBICULATION, with soucer-like depressions in a plane surface (cell wall), sometimes deep. Fig. 372

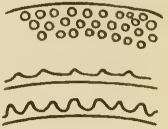

Figure 372

Scytonemo 174

Archangelii 174

Scytonematoceae 161, 175

Sea Weed 11

Sea Wrack 2

Selenastrum 53, 65 gracile 53

SEMICELL, a cell-holf, as in the Plocoderm desmids in which the cell has two parts that are miror images of one another, the two parts often connected by a narrow isthmus.

SEPTUM, a cross-partition, cross wall or a membrane complete or incomplete through the short diameter of a cell, sometimes porallel with the long oxis.

SERRATE, toothed; jogged. SETA, a hair, usually arising from within a cell wall; or a hair-like extension formed by topering of a filament of cells to a fine point. Fig. 373

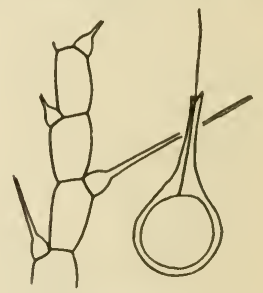

Figure 373

SHEATH, a covering, usuolly of mucilage, soft or firm; the covering of a colony of cells or on envelope about one or more filaments of cells. 


\section{HOW TO KNOW THE FRESH-WATER ALGAE}

SICKLE - SHAPED, acutely STAR-SHAPED, see Stellate cresecnt - shaped Staurastrum 75, 76 but curved more sharply than an arc of a circle. Fig. 374

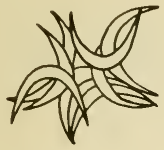

Figure 374

SIPHON; SIPHONOUS, a tube; a thallus without cross partitions.

Sirogonium 95

sticticum 95

SKEIN, a web-like expanse; a thin membranous growth.

Sloth 13

Snow Algae 13, 14, 34, 84, 129

Sorastrum 60

americanum 60

spinulosum 60

Species defined 3

Sphaerellopsis 34 fluviatilis 34

Sphaerocystis 48

Schroeteri 48

Sphoeroplea 103 annulina 103

Sphaerozosma 89 excavata 89

Sphagnum 15, 70, 90, 110 , 133

SPHERICAL, not quite sperical.

SPICULE, a scale or needle in the wall of cells or as a decoration on a cell wall.

SPINDLE-SHAPED, see Fusiform.

SPINE, a sharply - pointed projection from the cell wall.

Spirogyra, 95, 116; also 3, $6,72,94,101$ aequinoctialis 95 elongata 6 rhizobrachiales 95

Spirotaenia 72 condensata 72

Spirulino 158; also 159

laxissima 158

princeps 158

subsalso 158

Spondylomorum 27 quaternarium 27

Spondylosium 89 pulchrum 89

Sponge 65

SPORANGIUM, a cell (sometimes an unspecialized vegetative cell) which gives rise to spores; the case which forms about zygospores in the Zygnematales (Conjugales).

Starch 7, 8, 11

STARCH-TEST, See lodine Test cornutum 75

STELLATE, with radiating projections from a common center; star-like.

Stephanodiscus 186 . 187 niagarae 186

Stephanoptera 35 gracilis 35

Stephanosphaera 29 pluvialis 29

Stichococcus 104 bacillaris 104 so 108,112 flagelliferum 113

Stigonema 169 muscicola 169 ocellatum 169 turfaceum 169

Stinging Cells 23

STIPE, a stalk, slender.

tipitococcus 134

urceolatus 134 vasiformis 134

Stone-wort 1, 21

STRATIFIED, with layers

Stylosphaeridium 67 stipitatum 67

SUB-APICAL, slightly below the apex or below the anterior end.

SUBCYLINDRICAL, a figure which is elongate with lateral margins that are parallel for most of their length. See Cylindrical.

SUBFLAGELLAR, located at the base of or just below the point of origin of flagella.

SUBOUADRANGULAR, not rounded angles.

SUBSPHERICAL, not quite spherical. See Oblate.

SULCUS, groove or depression in cells of Dinoflagellatae. (See Peridinium, Fig. 258)

Surirella 188 splendida 188

SUTURE, a groove between plates, as in some Dinoflagellatae; a cleft-like crack or line in the spore wall as in some zygospores.

Symploca 163 muscorum 163

Synechococcus 183 . aeruginosus 183

Synechocystis 178 aquatilis 178

Synura 154; also 2

Adamsii 154

uvella 154

\section{T}

Tabellario 187

fenestrata 187

Tea 115 rotula 75

Stigeoclonium 113, 123; alquite square or with four
TEGUMENT, a skin; a firm outer covering.

TEST, a shell or covering external to the cell itself. See Lorica.

Tetmemorus 69

laevis 69

Tetradesmus 59

Smithii 59

wisconsinense 59

Tetradinium 149

javanicum 149

simplex 149

Tetraedron 87 ; also 6,86 , 149

asymmetricum 87

limneticum 87

lobulatum var. crassum 87 regulare var. bifurcatum 87

regulare var. granulatum 87

TETRAGONAL, with 4 angles which are arranged in two opposite pairs.

Tetragoniella 141 gigas 141

TETRAHEDRON, see Tetragonal

Tetrallantos 49, 59 Lagerheimii 49

Tetrapedia 183 Reinschiana 183

Tetraspora $38,44,45,100$. also $39,42,156$

cylindrica 38

gelatinosa 38

Tetrasporaceae 128

Tetrasporales $64,67,82,99$

Tetrastrum 55; also 56 heterocanthum 55

THALLUS, a plant body which is not differentiaated into root, stem and leaf organs; a frond; the algal plant.

Thea 115

THECA; THECATE, a firm outer wall, a shell, sometimes with plates as in the Dinoflagellatae.

Thorea 125

ramossisima 125

Tolypella 20 intricata 20

Tolypothrix 174 distorta 174

TOW: TOW SAMPLE, collecting with a plankton net by drawing it through the water.

Trachelomonas 24; also 22 granuloso 24

Trachychloron 141 biconnicum 141

TRANSVERSE FURROW, groove extending lateral around a cell as in the Dinoflagellatae. Fig. 375

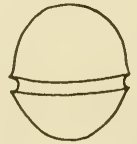

Figure 375 
TRAPEZIFORM; TRAPEZOID, a figure which has two parallel sides; shaped somewhat like a trapezoid. Fig. 376

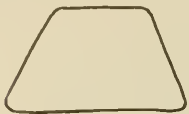

Figure 376

Trebouxia 80

Cladoniae 80

Trentepohlia 109, 116, 119;

also 10,13

aurea 109

lolithus 109

Treubaria 87

crassispina 87

Tribonema 131; also 132

bombycinum 131

bombicinum var. tenue 131 utriculosum 131

TRICHOCYST, organelle which is capable of throwing out stinging fibrils of mucilage. (See Gonyostomum, Fig. 4.)

Trichodesmium 162, 163 erythraceum 162 lacustris 162

TRICHOGYNE, a slender extended neck on the female sex organ (carpogonium) of the Rhodophyta.

TRICHOME, a thread; the series of cells in the $\mathrm{Cy}$ anophyta exclusive of o sheath which may be present; a fine hair-like extension.

Triploceras 70 gracile 70

Trochiscia 80

granulata 80

obtusa 80

reticularis 80

TRUE BRANCH, a branch formed by means of lateral division of cells in the main filament of a plant.

TRUNCATE, cut off abruptly at the tip: flat at the end as opposed to being rounded or pointed. Fig. 377

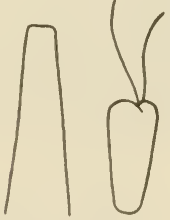

Figure 377

TUBERCLE, a button-like knob or protuberance.
TUBULAR; TUBULAR IHALLUS, a thread-like growth without cross walls; plant body in the form of a tube.

TUMID, swollen or convex on the sides. Fig. 378

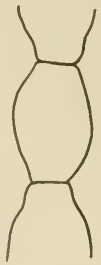

Figure 378

Tuomeya 126

fluviatilis 126

Turtle 13, 19

TYCHOPLANKTON, the plankton of waters near shore: organisms floating and entangled a mon weeds and in algal mots, not in the open water of a lake or stream

\section{1}

Ulothrix 107, 108; also 101 aequalis 107 cylindricum 107 zonata 107

Ulotrichales 53

Ulvella 115 involens 115

UNDULATE, regularly wavy.

UNILATERAL, on one side.

UNISERIATE, cells arranged in a single row. See Multiseriate.

Urococcus 82 insignis 82

Uroglenopsis 155 americana 155

Uronema 108 elongatum 108

UTRICLE, a sac-like or tubular sheath, usually a firm mucilaginous coverin?. Fig. 379

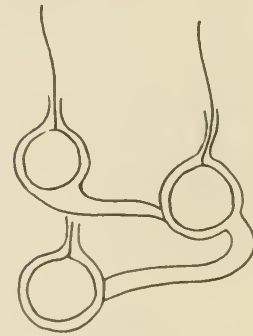

Figure 379

Utricularia 15,5
VALVE, one of two parts of a diatom cell wall; valve view, when the cell is seen from the top or bottom; girdle view, when the cell is seen from the side which thus shows the overlapping of the two valves.

Vaucheria 124

geminata 124

sessilis 124

VEGETATIVE, referring to o non - reproductive stage activity, or cell, as opposed to activities and stages involved in reproduction, especially sexual reproduction.

VENTRAL, the under or lower side or surface of an orgonism or cell.

VERMIFORM, long, narrow and crooked in shape worm-shaped.

VERRUCA, a warty projection; a protrusion which bears knobs or spines. Fig. 380 .

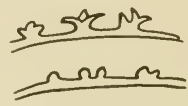

Figure 380

VERRUCOSE, roughened with irregular thickenings on the surface. Fig. 381

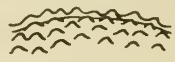

Figure 381

VESICLE, a sac or balloonlike cell or thallus.

Volvocaceae 26

Volvocales $27,36,84$

Volvox 28; also 29,30155 tertius 28

\section{W}

WATER BLOOM, a profuse growth of planktonic algoe which cloud or color the water, often forming floating scums.

Water Net (Hydrodictyon) 54

Westella 60 botryoides 60

WHORL, several parts, branches or leoves arising at one level from around an axis.

Wislouchiella 32 planctonica 32

Wollea 171 saccato 17 
HOW TO KNOW THE FRESH-WATER ALGAE

\section{$\mathbf{X}$}

Xanthidium 77 cristatum var. uncinatum 77

Xanthophyceae

124, 134

XANTHOPHYLL, a yellow pigment of several kinds associated with chlorophyll, $\mathrm{C}_{46} \mathrm{H}_{56} \mathrm{O}_{2}$.

Xenococcus 176 Schousbei 176

Yellow-brown Algae 6
Y
Zoochlorella 65,83
conductrix 65
parasitica 65
ZOOSPORE, an animal-like
spore equipped with fla-
gella and usually with an
eye-spot.

Zygnema 93; also 3,92 pectinatum 93

Zygnemataceae 3

Zygnematales 95

Zygnemopsis 92 decussata 92

desmidioides 92

Zygogonium 93

ericetorum 93

ZYGOSPORE, spore resulting from the union of gametes (sex cells); a resting stage. 




the FRESH-WATER ALgAE 